\title{
Goldschmidt 2002
}

PROGRAMME VOLUME

$18^{\text {th }}-23^{\text {rd }}$ August 2002

Davos, Switzerland 
Goldschmidt 2002

Map of the Congress Center, Davos

Showing lecture theatres, poster areas and exhibition booths

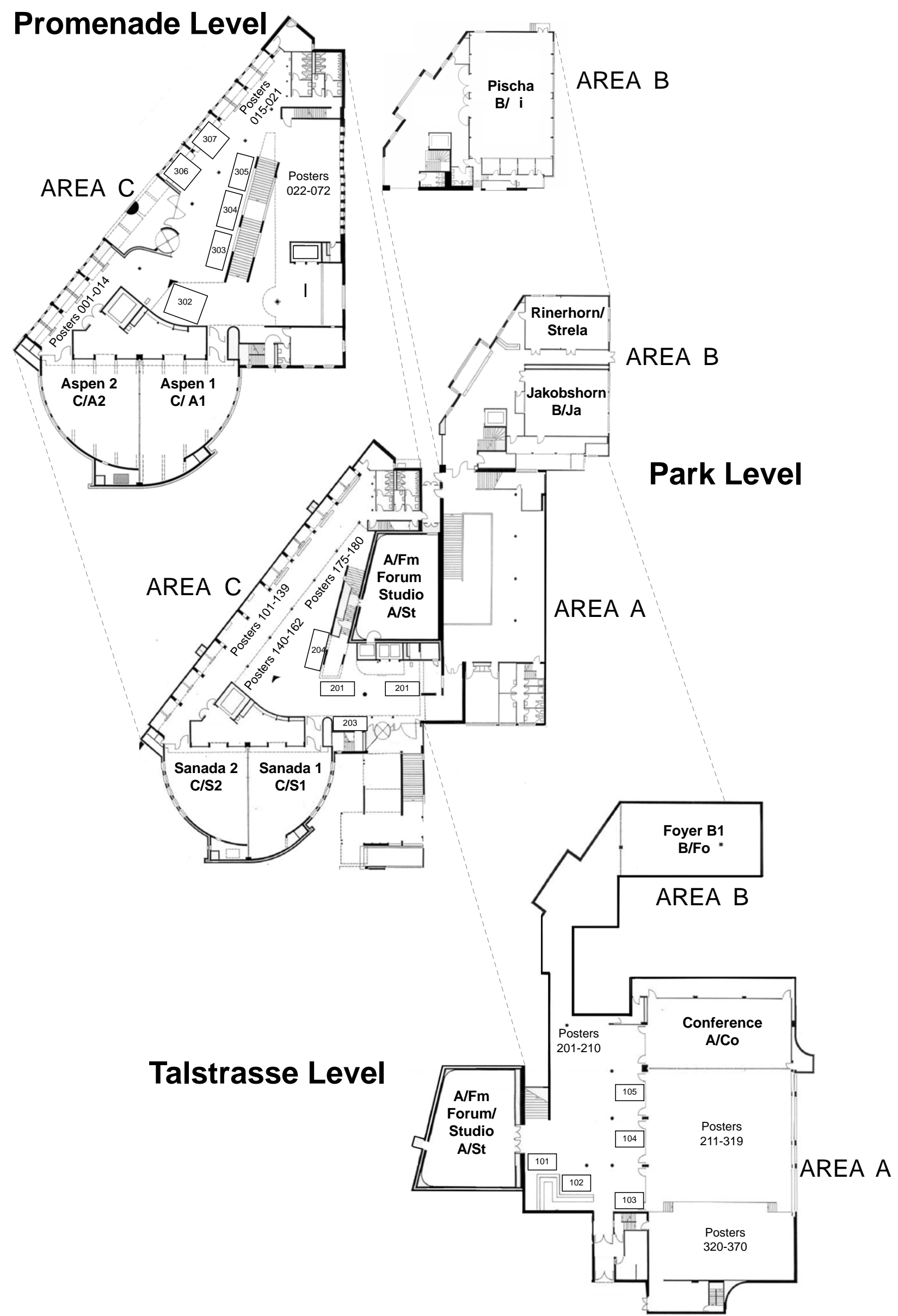




\section{Goldschmidt 2002}

\section{INDEX}

Maps of the Congress Center

ii

Letter of Welcome

Conference Information and Events vi

Information about Symposia

Lists of Symposia and their Chairs

viii

Times for Presentations in Each Symposia

Information for Presenting Authors

Information for Oral and Poster Presentations xii

Instructions for Projectionists xiv

Field Trips and Excursions $\quad$ XV

Goldschmidt Committees $\quad$ xvi

Sponsors and Exhibitors $\quad$ xviii

Awards at Goldschmidt $2002 \quad$ xxi

Abstracts of Plenary Lectures xxii

Conference Programme 1

Sunday 18th August $2002 \quad$ Oral Presentations 2

Monday 19th August $2002 \quad$ Oral Presentations 12

Monday 19th August $2002 \quad$ General Poster Session 1

Tuesday 20th August $2002 \quad$ Plenary Session 35

Wednesday 21st August 2002 Oral Presentations 36

Thursday 22nd August 2002 Oral Presentations 46

Thursday 22nd August 2002 General Poster Session 2

Friday 23rd August $2002 \quad$ Oral Presentations 72

Index of Authors $\quad 83$

Overviews of Oral Presentations 109 


\section{Welcome to Goldschmidt 2002 and to Davos!}

On behalf of the convenors, I would like to welcome you to the Goldschmidt, the 2002 Geochemistry Conference. The Goldschmidt Conference is the premier meeting in geochemistry world-wide and is primarily sponsored by the European Association of Geochemistry and the Geochemical Society. This year's meeting is of special significance for several reasons, many of which represent a "first". These include:

- this meeting was for the first time organised by the geochemists of Switzerland, the birth place of Victor Moritz Goldschmidt

- for the first time the meeting incorporates the quadrennial International Conference of Geochronology, Cosmochronology and Isotope Geology (ICOG)

- $\quad$ it is the largest geochemistry conference ever held by a long mark with 1750 submitted abstracts, almost double the attendance of any previous Goldschmidt Conference

- we have deliberately attempted to tackle in a reasonably comprehensive fashion the gamut of geochemistry "from Stars to Life"

- we have, for the first time, established a 100-strong International Program Committee that has done an outstanding job of proposing excellent special sessions and chairs

- the meeting was supported by a broader array of scientific organisations than before spanning the spectrum of geochemistry from that represented by the European Association of Organic Geochemists to that of the Mineralogical Society of America

- the abstracts are for the first time being published by Elsevier in Geochimica et Cosmochimica Acta, the world's most prestigious geochemistry journal.

This is a meeting for everybody concerned with, and interested in, the science of geochemistry. It is particularly strong in fascinating new discoveries that are being made by harnessing the power of sophisticated new geochemical tools, the behaviour of key elements and the rapidly expanding field of isotope geochemistry. We enjoy many other conferences but getting together just once a year with the world's geochemists seems to provide the opportunity for just the right-sized regular dose of interaction with the overall field. It is hoped that at this meeting you will able to familiarise yourself with much that is happening in other areas of geochemistry at the same time as being able to meet with colleagues in your own speciality.

From my limited perspective geochemistry has never been stronger or more interesting and this is the essential reason for holding the meeting. Let it please die swiftly when it is no longer useful. But for now the new opportunities to investigate unexplored areas of the natural world, often at the interfaces between traditionally distinct disciplines, are ready to be plundered with unparalleled vengeance. Many of us are getting more fun out of science than ever because of the brilliantly exciting new insights that are being obtained through the development of new geochemical techniques. It is a fantastic time to be a geochemist and the presentations in this conference demonstrate it over and over again. 
As some of you may be aware, a team effort like this actually means that certain players had to invest more effort than others. At the top of this list are Rainer Wieler, Valentina Mueller-Weckerle at ETH and Paul Beattie and his team. Jan Kramers and I have done a lot but we are not quite in their league. I really need to thank them and also the Organizing Committee comprising more than 30 scientists from across Switzerland. Their names are given elsewhere in this volume.

There is one very special aspect of this conference that should be explained here and that is the way in which we put together the program. For the first time we have an "official" International Program Committee (IPC) without whose advice and input this meeting would not have been anything like as successful. Goldschmidt is no longer a conference that belongs solely to local organisers. It has become too big for that and the entire geochemistry community has a vested interest in using it as an effective vehicle for meeting and presenting research. Fortunately geochemistry is booming in Switzerland and there are lots of talented people here but the program has to be defined with input from an even broader cross section of scientists. This has the added bonus that the whole world can feel involved. It is a meeting for everybody in geochemistry.

To arrange this the Swiss Program Committee divided up the science into 13 themes, each of which needed an international team of experts. Two chairs headed each of these teams or Task Groups. We picked these chairs almost two years before the conference, and all agreed to serve with no hesitation, and the chairs picked their Task Groups with a bit of input from the Swiss. This 100strong IPC then proposed special sessions (about 80 of them) and their potential chairs, as well as ideas for keynote speakers. The Swiss Program Committee then merged many of these because there were inevitably many overlaps, and finally came up with about 50 - our target for the meeting. These special symposia are in addition to the general symposia we had planned to cover the broad scope of geochemistry. We then contacted the session chairs (more than 100) nearly all of whom also agreed to serve and they in turn invited an excellent slate of keynote and invited speakers. I think this structured and organised sharing of responsibility is a great way to do things and I recommend that the GS / EAG make it a standard practice for the future.

In closing one has to mention all of the background and logisitical support provided by others. The Lunar and Planetary Institute really wanted to help us with Goldschmidt but were prevented from doing so and pulled out at the last minute just when we were about to produce the first circular. We turned to a number of people and organisations for help and advice including ETH, the American Geophysical Union, Elsevier, the organizers of the Virginia Goldschmidt and the Boards of the Geochemical Society and the European Association of Geochemistry. Judy McKenzie, Mike Hochella and Bob Bodnar in particular provided lots of useful tips and advice. In the end things have worked out very well. The costs were inevitably a little higher than would otherwise have been the case but this has been more than compensated by the modestly priced accommodation. Cambridge Publications have proved themselves to be outstanding partners who have worked very hard to give us the kind of abstract submission procedures, deadlines, program organisation and web pages that we wanted. Finally we have to mention Davos Tourism who are so nice and helpful that it reminds you how nice it is to visit or live in this great country called Switzerland. Have a great meeting and take good advantage of this great opportunity to talk, talk, talk...

Alex Halliday 


\section{CONFERENCE INFORMATION}

\section{Conference Location}

Goldschmidt 2002 will be held in the Congress Center at Davos, Switzerland. The layout of the Congress Center can be seen from the map on page ii. It is made up of three sections (Areas A, B and C), all of which are in the same building. The Congress Center will be open from 07.30 each day: showing the conference badge (included with each delegate's registration pack) will be sufficient to ensure entry.

The Congress Center will host the registration and all oral and poster presentations, including the medal ceremonies and plenary lectures on Tuesday morning. The icebreaker party on Saturday evening, the reception by the City of Davos on Sunday evening and the Banquet on Wednesday evening will also be at the Congress Center.

The Swiss Alpine Evening on Monday will take place at the Rinerhorn, near Davos, with transportation provided from the Congress Center. The Farewell party on Friday evening will be at the Restaurant Bolgen Plaza, near the cable car station to Jakobshorn.

\section{Pre-Registration}

Delegates who have pre-registered and completely paid their fees will be able to collect their conference material on arrival at the Pre-Registration desks.

\section{Registration}

All other delegates, including those who wish to register on site or purchase a one-day registration should do this at the registration desk. The registration desk will be open at the following times:

$\begin{array}{ll}\text { Saturday, August 17th } & 14.00-20.00 \\ \text { Sunday, August 18th } & 07.30-16.00 \\ \text { Monday, August 19th } & 08: 30-16: 30 \\ \text { Tuesday, August 20th } & 08: 30-12: 00 \\ \text { Wednesday, August 21st } & 08: 30-16: 30 \\ \text { Thursday, August 22nd } & 08: 30-16: 30 \\ \text { Friday, August 23rd } & 08: 30-12: 00\end{array}$

\section{Publications}

All delegates will receive a copy of the programme volume containing the abstracts and programme CDROM. Delegates will also receive a printed copy of the abstract volume, which has been produced by Cambridge Publications and printed by Elsevier Science as a supplement to Geochimica et Cosmochimica Acta

\section{Computing and Internet Access}

The Internet Center will be equipped with more than 30 PCs, and spaces for delegates to use laptops. These computers will run Windows 2000 and PowerPoint 2000 will be installed. This facility will enable delegates to revise PowerPoint presentations and save the results onto $\mathrm{CD}$, if required. Software to enable delegates to access their email accounts will also be installed on these machines. The Internet Center is situated on the Mezzanine floor between the Aspen and Sanada Foyers in Area B.

\section{Refreshments}

There will be no formal coffee breaks, but coffee will be served during morning and afternoon sessions. Beer and mineral water will be served at the poster sessions on Monday and Thursday afternoon, between 16:30 and 18:00.

\section{Messages}

There will be a message board close to the Helpdesk. Messages can be left at the Helpdesk for collection by delegates. Messages can also be sent to the following fax number: +41 814146426 , or, in urgent cases, by phone to +41814146407 . The postal address of the Congress Center is Promenade 92, Davos Dorf, Switzerland.

\section{Accommodation}

Accommodation bookings have been arranged via Davos Tourism, taking advantage of the special rates made available for the conference. A member of the Davos Tourism team will be available at the Helpdesk on request. 


\section{CONFERENCE EVENTS}

\section{Scientific Events}

\section{Oral Presentations}

The sessions of oral presentations will take place from 08:30-12:30 and from 13:30-16:30 on Sunday, Monday, Wednesday, Thursday and Friday. The times allocated for the oral presentations of each symposium can be seen from the charts on pages $\mathrm{x}$ and $\mathrm{xi}$, together with the room in which they will take place.

\section{Poster Sessions}

The special poster sessions for each symposium will take place on the morning or afternoon of Sunday, Monday, Thursday or Friday. The time of the special symposium for each symposium is given in the programme, and can also be seen from the charts on page $\mathrm{x}$ and $\mathrm{xi}$. Authors will be available to discuss their posters from 11:00-12:30 for morning sessions, and from 13:30-15:00 for afternoon sessions.

In addition to these special poster sessions there will also be two general poster sessions at which refreshments will be available. The Monday general poster session is sponsored by EPSL Frontiers and will contain the posters of all those symposia with special poster sessions on Sunday or Monday. The second general poster session will take place on Thursday for the posters of the other symposia and is sponsored by Science magazine. Both the general poster sessions will take place from 16:30-18:00.

\section{The Plenary Session}

The Plenary Session will take place in the Theatre Hall in Area A on Tuesday from 08:30. This session will include the awarding of the medals of the European Association for Geochemistry and the Geochemical Society, and the plenary lectures. The timetable for the Plenary Session can be found on page 35 .

\section{Social Events}

\author{
The Icebreaker Party \\ Saturday August 17th, 18:00-21:00 \\ Sponsored by $\mathrm{Nu}$ Instruments
}

\author{
Reception by the Mayor of Davos \\ Sunday August 18th, 17:15-19:00 \\ Sponsored by Landschaft Davos
}

\section{Traditional Swiss Alpine Evening \\ Monday August 19th, 18:00-22:30}

This will take place on the Rinerhorn. Those who have booked places will find their tickets in their registration envelope at the bottom of their registration receipt. Further tickets may be purchased from the Helpdesk while places remain. Departure for Rinerhorn will be from the front of the Congress Center (At the Aspen Exit at Promenade Level) from 18:00-18:20. Delegates will be brought back to the Congress Center at about 22:30-23:00.

\section{The Conference Banquet \\ Wednesday August 21st, 19:00-23:00}

This will take place in the Theatre Hall of the Congress Center. Those who have booked places will find their tickets in their registration envelope at the bottom of their registration receipt. Further tickets may be purchased from the Helpdesk while places remain.

\section{Farewell Party}

Friday August 23rd, from 18:00

This will take place in the Bolgen Plaza Restaurant, which is situated near the cable car station to Jakobshorn. Further directions are available from the Helpdesk. 


\section{SYMPOSIA}

\section{General Symposia}

G01: Geochronology (Urs Schaltegger, Mike Cosca \& Jost Eikenberg)

G02: $\quad$ Merged with symposium S23

G03:

G04:

G05:

G06: $\quad$ Metamorphic Geochemistry and Crustal Fluids (Lucas Baumgartner \& Christoph Heinrich)

G07: Geochemistry of Pollution (Malcolm McCulloch \& Björn Öhlander)

G08: $\quad$ Geochemistry of the Earth, Planets and Meteorites (Der-Chuen Lee \& Ingo Leya)

G09: $\quad$ Geochemistry and Mineral Physics (Max Schmidt \& Martin Kunz)

G10: $\quad$ Computational Geochemistry (Thomas Driesner)

\section{Special Symposia}

S01: Presolar Grains and Gases (Uli Ott \& Larry Nittler)

S02: Stars, Disks and Planetary Growth

(Brigitte Zanda, Conel Alexander, Herbert Palme \& Ed Young)

S03: Early Differentiation of Earth and Other Planets

(Mini Wadhwa, Monica Grady, Kevin Zahnle \& Kevin Righter)

S04: Impact Hazards from Comets and Asteroids (Philippe Claeys)

Co-sponsored by the European Science Impact Programme

S05: Source of Organic Compounds on the Early Earth and Other Solar System Bodies

(Gerda Horneck \& André Brack)

S06: The Pre-RNA World and the Origin of Life (Antonio Lazcano, Francis Westall \& Jeffrey Bada)

S07: Archean and Proterozoic Oceans, Climates, and Geochemistry

(Balz Kamber, Dan Schrag, Minik Rosing \& Don Canfield)

S08: Komatiites (Nicholas Arndt, Janne Blichert-Toft \& Tim Grove)

S09: Core - Mantle Exchange (Don Porcelli, Bernie Wood \& Rich Walker)

S10: Geodynamics and Deep Earth Reservoirs (John Lassiter, Peter van Keken \& John Brodholt)

S11: Mantle Melting and Magma Transport (Pierre Schiano \& Paul Asimow)

S12: Mantle Volatiles: Primordial v Recycled (Pete Burnard, Bernard Marty \& Mike Carroll)

S13: Subduction Factory: From Ocean to Mantle (Derrill Kerrick \& Peter Ulmer)

S14: Characterising Slab, Mantle and Crustal Contributions to Arcs (Mike Dungan \& Jon Davidson)

S15: Trace Element Fingerprinting: Laboratory Studies and Petrogenetic Processes

(Sue O’Reilly \& Ricardo Vannucci)

S16: Magmatic Differentiation - Rates and Processes (Charlie Bacon \& Steve Blake)

S17: Magma Chambers and Ore-forming Processes at the Magmatic - Hydrothermal Interface

(Jim Webster \& Werner Halter)

S18: $\quad$ Properties of Geological Fluids and Solutes - From Experiment to Simulation

(Terry Seward \& Craig Manning)

S19: Innovative Interpretations of Experimental and Field Geochemical Processes Using Reactive

Transport Modeling (C. Steefel, C. Ayora \& P. Van Cappellen)

S20: Linking Geochronology with Petrology and Textures (Wolfgang Müller \& Derek Vance) 


\section{Goldschmidt 2002}

\section{SYMPOSIA}

S21: $\quad$ Erosion Factory I (Nathalie Vigier \& Ken Farley)

S22: $\quad$ Erosion Factory II (Jerome Gaillardet \& Bernhard Peucker-Ehrenbrink)

S23: $\quad$ Ocean Productivity: Past and Present

(Martin Frank, Stefano Bernasconi \& Kimitaka Kawamura)

S24: $\quad$ Ocean Paleotemperatures (David Lea, Ros Rickaby \& Thomas Nägler)

S25: $\quad$ Phanerozoic History of Greenhouse Gases (Jerry Dickens, Mark Pagani \& David Beerling)

S26: Mediterranean Sapropels and their Relationship to Global Climate Variations

(Gert J. De Lange, Hans-J. Brumsack, Philip A. Meyers \& Judith A. McKenzie)

S27: $\quad$ Sources and Sinks of Aerosols and Dust

(Bruno Hamelin, Sidney Hemming \& Karen Kohfeld)

S28: $\quad$ Ice Age Terminations and Other Rapid Climate Changes

(Gideon Henderson, Claudine Stirling \& Joerg Schaefer)

S29: Hominid Origin and Behaviour - Archeometric Approach (Gunther Wagner \& Peter Horn)

S30: $\quad$ Biogeochemical Processes in Lakes

(Bernhard Wehrli, Liba Granina \& Jean François Gaillard)

S31: Environmental Tracers for Groundwater Dating (Gisela Winckler \& Bernhard Lehmann)

S32: Halogenated Organic Compounds in the Biosphere, Geosphere and Atmosphere

(Walter Michaelis \& Heinz F. Schöler)

S33: $\quad$ The Deep Biosphere - Microbial Communities in Deeply Buried Media

(Tim Ferdelman, Tommy Phelps \& Andreas Teske)

S34: High-temperature Organic Geochemistry and the Thermal Alteration of Petroleum

(Jeff Seewald, Steve Larter \& Everett Shock)

S35: $\quad$ Molecular Tools for the Identification of Important Geomicrobial Organisms

(Dianne Newman \& Antje Boetius)

S36: Biogenic Substances and their Effect on Trace Metal Cycling and Mineral Weathering

(Stephan Kraemer \& Javiera Cervini-Silva)

S37: $\quad$ Colloids: Their Nature, Reactivity, and Role in the Transport of Pollutants

(Gordon Brown \& Daniel Grolimund)

S38: $\quad$ Advances in Tracing Sources and Fates of Pollutants in Ground Waters

(Stefan Haderlein \& Nadya Teutsch)

S39: $\quad$ New Geochemical Approaches to Energy, Waste and the Environment (Reto Giere \& Peter Stille)

S40: $\quad$ Noble Gases in Geochemistry and Cosmochemistry

(Don Porcelli, Chris Ballentine \& Rainer Wieler)

S41: $\quad$ The Stable Isotope Geochemistry of "Heavy" Elements

(Jane Barling, Xiangkun Zhu, Tom Bullen \& Chloé Marechal)

S42: $\quad$ Ocean Circulation: Past and Present (Catherine Jeandel, Jess Adkins \& Ian Hall)

S43: $\quad$ The Isotope Geochemistry of Hydrogen (John Eiler \& Francois Robert)

S44: $\quad$ Recent Advances in ICPMS and High-precision Isotope Ratio Mass Spectrometry

(Mark Rehkämper, Steve Galer \& Dieter Garbe-Schönberg)

S45: Novel Approaches and New Techniques in Dating Minerals, Rocks, and Geological

Processes (Igor Villa \& Holly Stein)

S46: $\quad$ Technique Developments in Cosmogenic Nuclides (Susan Ivy-Ochs \& Tim Jull)

S47: Microanalysis Mass-spectrometric Techniques (D. Günther \& N. Shimizu)

S48: $\quad$ Small-scale Processes in Heterogeneous Environments with Relevance to Environmental

Biogeochemistry (Andre Scheidegger, Ruben Kretzschmar \& Mike Hochella)

S49: $\quad$ The Geochemistry of Biogenic Minerals

(Anne Cohen, Patricia Dove, Nobuchimi Shimizu \& Steve Weiner) 


\section{ROOM NAMES AND POSTER NUMBERS SUNDAY - MONDAY}

\begin{tabular}{|c|c|c|c|c|c|c|c|c|c|}
\hline \multirow[b]{2}{*}{ Symposium } & \multicolumn{2}{|c|}{ Sun Aug 18 am } & \multicolumn{2}{|c|}{ Sun Aug 18 pm } & \multicolumn{2}{|c|}{ Mon Aug 19 am } & \multicolumn{2}{|c|}{ Mon Aug 19 pm } & \multirow{2}{*}{$\begin{array}{l}\text { Mon Aug } 19 \text { pm } \\
\text { General Posters }\end{array}$} \\
\hline & Oral & Poster & Oral & Poster & Oral & Poster & Oral & Poster & \\
\hline G01 & & & & & & & & $257-290$ & $257-290$ \\
\hline G02 & & & B/Fo & & & & & & \\
\hline G03 & & & & & & & & $226-241$ & $226-241$ \\
\hline \multicolumn{10}{|l|}{ G04 } \\
\hline \multicolumn{10}{|l|}{ G05 } \\
\hline \multicolumn{10}{|l|}{ G06 } \\
\hline G07 & & & & $320-350$ & $\mathrm{~B} / \mathrm{Ja}$ & & $\mathrm{B} / \mathrm{Ja}$ & & $320-350$ \\
\hline G08 & & & & & & & & $155-158$ & $155-158$ \\
\hline G09 & $\mathrm{A} / \mathrm{Fm}$ & & $\mathrm{A} / \mathrm{Fm}$ & & & $110-134$ & & & $110-134$ \\
\hline \multicolumn{10}{|l|}{ G10 } \\
\hline S01 & $\mathrm{C} / \mathrm{S} 1$ & & & & & $142-147$ & & & $142-147$ \\
\hline S02 & & $148-153$ & $\mathrm{C} / \mathrm{S} 1$ & & $\mathrm{C} / \mathrm{S} 1$ & & $\mathrm{C} / \mathrm{S} 1$ & & $148-153$ \\
\hline \multicolumn{10}{|l|}{$\mathrm{S} 03$} \\
\hline \multicolumn{10}{|l|}{ S04 } \\
\hline S05 & & & & $163-165$ & & & $\mathrm{C} / \mathrm{S} 2$ & & $163-165$ \\
\hline S06 & & & & & $\mathrm{C} / \mathrm{S} 2$ & & & & \\
\hline S07 & $\mathrm{C} / \mathrm{S} 2$ & & $\mathrm{C} / \mathrm{S} 2$ & & $\mathrm{C} / \mathrm{S} 2$ & & & $166-173$ & $166-173$ \\
\hline \multicolumn{10}{|l|}{ S08 } \\
\hline \multicolumn{10}{|l|}{ S09 } \\
\hline S10 & & & & & & & & & \\
\hline S11 & & $44-56$ & $\mathrm{C} / \mathrm{A} 1$ & & $\mathrm{C} / \mathrm{A} 1$ & & $\mathrm{C} / \mathrm{A} 1$ & & $44-56$ \\
\hline S12 & & & $\mathrm{C} / \mathrm{A} 2$ & & & $34-43$ & & $34-43$ & $34-43$ \\
\hline $\mathrm{S} 13$ & $\mathrm{C} / \mathrm{A} 2$ & & & & & $15-21$ & & & $15-21$ \\
\hline S14 & & & & $1-14$ & $\mathrm{C} / \mathrm{A} 2$ & & $\mathrm{C} / \mathrm{A} 2$ & & $1-14$ \\
\hline $\mathrm{S} 15$ & $\mathrm{C} / \mathrm{A} 1$ & & & & & $59-69$ & & & $59-69$ \\
\hline S16 & & & & & & & & & \\
\hline S17 & & & & & & & & & \\
\hline S18 & & & & & & & & & \\
\hline S19 & & & & & & & & & \\
\hline S20 & & & & $24-29$ & $\mathrm{~A} / \mathrm{Co}$ & & $\mathrm{A} / \mathrm{Co}$ & & $24-29$ \\
\hline S21 & & & & & & & & & \\
\hline S22 & & & & & & & & & \\
\hline S23 & & & B/Fo & $201-210$ & & & & $201-210$ & \\
\hline S24 & & & & $211-216$ & B/Fo & & B/Fo & & $211-216$ \\
\hline S25 & & & & & & & & & \\
\hline S26 & & & & & & & & & \\
\hline S27 & & & & & & & & & \\
\hline S28 & & & & & & & & & \\
\hline S29 & & & & & & & $\mathrm{A} / \mathrm{St}$ & & \\
\hline S30 & & $248-256$ & & & $\mathrm{~B} / \mathrm{Pi}$ & & $\mathrm{B} / \mathrm{Pi}$ & & $248-256$ \\
\hline S31 & & & & & & & & & \\
\hline S32 & & & $\mathrm{B} / \mathrm{Pi}$ & & & & & & \\
\hline S33 & $\mathrm{B} / \mathrm{Pi}$ & & & & & $242-243$ & & & $242-243$ \\
\hline S34 & & & & & & & & & \\
\hline S35 & & & & & & $244-247$ & & & $244-247$ \\
\hline S36 & & & & & & & & & \\
\hline S37 & & & & & & & & & \\
\hline S38 & & & & & & & & & \\
\hline S39 & & & & & & & & & \\
\hline $\mathrm{S} 40$ & & & & & & & & & \\
\hline S41 & & & & & & & & & \\
\hline S42 & B/Fo & & & & & $217-225$ & & & $217-225$ \\
\hline S43 & & & & & & & & & \\
\hline S44 & $\mathrm{A} / \mathrm{St}$ & & $\mathrm{A} / \mathrm{St}$ & & & $293-306$ & & & 293-306 \\
\hline S45 & $\mathrm{A} / \mathrm{Co}$ & & $\mathrm{A} / \mathrm{Co}$ & & & 30-33 & & & $30-33$ \\
\hline S46 & & & & & & & & & \\
\hline S47 & & & & & $\mathrm{A} / \mathrm{St}$ & & & $311-319$ & $311-319$ \\
\hline S48 & $\mathrm{B} / \mathrm{Ja}$ & & $\mathrm{B} / \mathrm{Ja}$ & & $\mathrm{B} / \mathrm{Ja}$ & & & $351-367$ & $351-367$ \\
\hline S49 & & & & $101-109$ & $\mathrm{~A} / \mathrm{Fm}$ & & $\mathrm{A} / \mathrm{Fm}$ & & $101-109$ \\
\hline
\end{tabular}




\section{ROOM NAMES AND POSTER NUMBERS WEDNESDAY - FRIDAY}

\begin{tabular}{|c|c|c|c|c|c|c|c|c|c|c|c|}
\hline \multirow[b]{2}{*}{ Symposium } & \multicolumn{2}{|c|}{ Wed Aug 21} & \multirow{2}{*}{\multicolumn{2}{|c|}{ Thur Aug 22 am }} & \multicolumn{2}{|c|}{ Thur Aug $22 \mathrm{pm}$} & \multirow{2}{*}{$\begin{array}{l}\text { Thur Aug } 22 \mathrm{pm} \\
\text { General Posters }\end{array}$} & \multicolumn{2}{|c|}{ Fri Aug 23 am } & \multicolumn{2}{|c|}{ Fri Aug $23 \mathrm{pm}$} \\
\hline & Oral am & Oral Pm & & & Oral & Poster & & Oral & Poster & Oral & Poster \\
\hline G01 & & & $\mathrm{A} / \mathrm{St}$ & & $\mathrm{A} / \mathrm{St}$ & & & & & & \\
\hline G02 & & & & & & & & & & & \\
\hline G03 & & \multirow[t]{2}{*}{ B/Fo } & & & & & & & & & \\
\hline G04 & \multirow{4}{*}{$\mathrm{C} / \mathrm{A} 1$} & & $\mathrm{~B} / \mathrm{Pi}$ & $230-258$ & $\mathrm{~B} / \mathrm{Pi}$ & & $230-258$ & $\mathrm{~B} / \mathrm{Pi}$ & & $\mathrm{B} / \mathrm{Pi}$ & \\
\hline G05 & & $\mathrm{C} / \mathrm{A} 1$ & & & & $37-72$ & $37-72$ & & & & \\
\hline G06 & & & & & & $163-180$ & $163-180$ & $\mathrm{C} / \mathrm{S} 2$ & & $\mathrm{C} / \mathrm{S} 2$ & \\
\hline G07 & & \multirow{3}{*}{$\mathrm{C} / \mathrm{S} 1$} & & & & & & & & & \\
\hline G08 & \multirow[t]{3}{*}{$\mathrm{C} / \mathrm{S} 1$} & & & & & & & & & & \\
\hline G09 & & & & & & & & & & & \\
\hline G10 & & $\mathrm{A} / \mathrm{St}$ & & & & $275-280$ & $275-280$ & & & & \\
\hline \multicolumn{12}{|l|}{ S01 } \\
\hline \multicolumn{12}{|l|}{ s02 } \\
\hline S03 & & & $\mathrm{C} / \mathrm{S} 1$ & & $\mathrm{C} / \mathrm{S} 1$ & & $140-144$ & $\mathrm{C} / \mathrm{S} 1$ & & & $140-144$ \\
\hline S04 & & & & & & & $146-148$ & & $146-148$ & $\mathrm{C} / \mathrm{S} 1$ & \\
\hline s05 & & & & & & & & & & & \\
\hline so6 & & & & & & & & & & & \\
\hline S07 & & & & & & & & & & & \\
\hline s08 & $\mathrm{C} / \mathrm{A} 2$ & $\mathrm{C} / \mathrm{A} 2$ & & & & $15-20$ & $15-20$ & & & & \\
\hline s09 & & & $\mathrm{C} / \mathrm{A} 1$ & & & & & & & & \\
\hline s10 & & & & $112-139$ & $\mathrm{C} / \mathrm{A} 1$ & & $112-139$ & $\mathrm{C} / \mathrm{A} 1$ & & $\mathrm{C} / \mathrm{A} 1$ & \\
\hline $\mathrm{s} 11$ & & & & & & & & & & & \\
\hline $\mathrm{s} 12$ & & & & & & & & & & & \\
\hline s13 & & & & & & & & & & & \\
\hline s14 & & & & & & & & & & & \\
\hline S15 & & & & & & & & & & & \\
\hline S16 & & & & & & $22-36$ & $22-36$ & $\mathrm{C} / \mathrm{A} 2$ & & $\mathrm{C} / \mathrm{A} 2$ & \\
\hline S17 & & & $\mathrm{C} / \mathrm{A} 2$ & & $\mathrm{C} / \mathrm{A} 2$ & & $1-14$ & & $1-14$ & & \\
\hline $\mathrm{s} 18$ & $\mathrm{C} / \mathrm{S} 2$ & $\mathrm{C} / \mathrm{S} 2$ & & & & $150-154$ & $150-154$ & & & & \\
\hline s19 & & & $\mathrm{C} / \mathrm{S} 2$ & & $\mathrm{C} / \mathrm{S} 2$ & & $155-162$ & & $155-162$ & & \\
\hline s20 & & & & & & & & & & & \\
\hline S21 & $\mathrm{A} / \mathrm{Co}$ & $\mathrm{A} / \mathrm{Co}$ & & & & 284-293 & 284-293 & & & & \\
\hline S22 & & & & 294-308 & $\mathrm{A} / \mathrm{Co}$ & & 294-308 & $\mathrm{A} / \mathrm{Co}$ & & $\mathrm{A} / \mathrm{Co}$ & \\
\hline s23 & & & & & & & & & & & \\
\hline S24 & & & & & & & & & & & \\
\hline S25 & B/Fo & & & $211-213$ & & & $211-213$ & & & & \\
\hline s26 & & & & & B/Fo & & 201-205 & & 201-205 & & \\
\hline S27 & & & B/Fo & & & & $222-229$ & & $222-229$ & & \\
\hline $\mathrm{S} 28$ & & & & $214-219$ & B/Fo & & 214-219 & B/Fo & & B/Fo & \\
\hline s29 & & & & & & & & & & & \\
\hline s30 & & & & & & & & & & & \\
\hline s31 & & & $\mathrm{A} / \mathrm{Co}$ & & $\mathrm{A} / \mathrm{Co}$ & & $281-283$ & & $281-283$ & & \\
\hline s32 & & & & & & & & & & & \\
\hline S33 & & & & & & & & & & & \\
\hline s34 & & & $\mathrm{B} / \mathrm{Ja}$ & & & & $314-319$ & & $314-319$ & & \\
\hline S35 & $\mathrm{B} / \mathrm{Pi}$ & $\mathrm{B} / \mathrm{Pi}$ & & & & & & & & & \\
\hline S36 & & $\mathrm{B} / \mathrm{Pi}$ & $\mathrm{B} / \mathrm{Pi}$ & & & & $259-265$ & & $259-265$ & & \\
\hline S37 & $\mathrm{B} / \mathrm{Ja}$ & $\mathrm{B} / \mathrm{Ja}$ & & & & & $325-332$ & & $325-332$ & & \\
\hline S38 & & & & & $\mathrm{B} / \mathrm{Ja}$ & & $333-341$ & & 333-341 & & \\
\hline S39 & & & & & & $342-364$ & $342-364$ & $\mathrm{~B} / \mathrm{Ja}$ & & $\mathrm{B} / \mathrm{Ja}$ & \\
\hline S40 & $\mathrm{A} / \mathrm{Fm}$ & $\mathrm{A} / \mathrm{Fm}$ & $\mathrm{A} / \mathrm{Fm}$ & & & $106-111$ & $101-105$ & & & & \\
\hline S41 & & & & $101-105$ & $\mathrm{~A} / \mathrm{Fm}$ & & $106-111$ & $\mathrm{~A} / \mathrm{Fm}$ & & $\mathrm{A} / \mathrm{Fm}$ & \\
\hline S42 & & & & & & & & & & & \\
\hline $\mathrm{S} 43$ & $\mathrm{~A} / \mathrm{St}$ & & & & & $266-267$ & $266-267$ & & & & \\
\hline S44 & & & & & & & & & & & \\
\hline S45 & & & & & & & & & & & \\
\hline S46 & & & & & & $268-271$ & $268-271$ & $A / S t$ & & $\mathrm{~A} / \mathrm{St}$ & \\
\hline S47 & & & & & & & & & & & \\
\hline S48 & & & & & & & & & & & \\
\hline S49 & & & & & & & & & & & \\
\hline
\end{tabular}




\section{ORAL AND POSTER PRESENTATIONS}

\section{Finding each presentation}

The time and location of each presentation can be found from the programme (starting on page 1). For the poster presentations it gives the date and time of the special poster session for each symposium, and the number of the poster board on which each poster will be displayed. The map of the Congress Center (page ii) gives the position of each group of poster boards.

The programme gives the date, room and time of each oral presentation. The surname of the first author of each of the papers being presented at any given time can be seen from the timetable overviews (pages 109-128). Finally, the index to the volume gives all the information required to deduce the date, time and location of any presentation, together with the page number on which it will appear in the programme volume, the abstract volume and in the PDF files on the $\mathrm{CD}$ and on the conference website.

The room in which each presentation will take place is given by a room code. These are as follows:

$$
\begin{gathered}
\text { Area A } \\
\mathrm{A} / \mathrm{Co}=\text { Conference Hall } \\
\mathrm{A} / \mathrm{Fm}=\text { Forum } \\
\mathrm{A} / \mathrm{St}=\text { Studio } \\
\text { Area B } \\
\mathrm{B} / \mathrm{Fo}=\text { Foyer B1 } \\
\mathrm{B} / \mathrm{Ja}=\text { Jakobshorn } \\
\mathrm{B} / \mathrm{Pi}=\text { Pischa/Parsenn } \\
\text { Area C } \\
\mathrm{C} / \mathrm{A} 1=\text { Aspen } 1 \\
\mathrm{C} / \mathrm{A} 2=\text { Aspen } 2 \\
\mathrm{C} / \mathrm{S} 1=\text { Sanada } 1 \\
\mathrm{C} / \mathrm{S} 2=\text { Sanada } 2
\end{gathered}
$$

\section{Area C}

\section{Poster Presentations}

There are two groups of poster sessions at Goldschmidt 2002. The first set of posters will be displayed on Sunday and Monday (see pages 23-34) with a general poster session with refreshments sponsored by EPSL Frontiers from 16:30-18:00 on Monday. The second set of posters will be displayed on Thursday and Friday (see pages 57-71) with a general poster session with refreshments sponsored by Science magazine from 16:30-18:00 on Thursday.

Authors will be available to discuss their posters during the general poster sessions, and also during special poster sessions (11:00-12:30 for morning sessions, 13:30-15:00 for afternoon sessions). Posters should be removed at 18:00 on Monday and after 12:00 on Friday.

The posters will take place in the Foyers of Area $\mathrm{C}$ and in the Theatre Hall/Foyer of Area A. The positions of the posters can be seen from the maps of the Congress Center (page ii). Each poster board has a unique number attached. The number of the poster board on which each poster should be fixed is given in the programme.

The maximum useable size of the poster boards is $150 \mathrm{~cm}$ (width) times $100 \mathrm{~cm}$ (height). Posters should be attached to the boards using the double-sided tape which is available from the Helpdesk. 


\section{ORAL AND POSTER PRESENTATIONS}

\section{Oral Presentations}

All papers are allocated 15 minutes (including 5 minutes for discussion) unless they are medallist or keynote lectures, most of which have been allocated 30 minutes (including 7 minutes for discussion). The times of the presentations are the same in each of the 10 parallel sessions so that delegates may move between different symposia. Symposium chairs have therefore been requested to ensure that they adhere strictly to this timetable so that delegates are not inconvenienced.

All lecture halls are equipped with two screens, two 36x24 mm slide projectors, two overhead projectors and one beamer plus laptop computer for PowerPoint presentations.

Delegates are asked to complete their "Instructions for Projectionists" form and provide this with their slides and/or CD at the Projection Center. A copy of this form was included in the conference bag, and a further copies can be obtained from the Projection Center; it has also been printed on page xiv for your convenience.

\section{PowerPoint Presentations:}

Files for PowerPoint presentations need to be on Compact Disk, and the CDs need to be handed in at the Projection Center not later than the evening before the talk is scheduled. Disks should be labelled with name of speaker, symposium code, and day and time of presentation, and also with the name of the file to be used (e.g. Smith.ppt). The computers from which the PowerPoint presentations will be beamed will have PowerPoint 2000 (from Office 2000 professional) installed, running on Windows 2000. Delegates should ensure that their presentations are compatible with this operating system and PowerPoint version. No problems are expected for delegates using versions of Powerpoint before 2000 whose presentations do not include video. Computers in the Internet Corner will be equipped with $\mathrm{CD}$ burning software, allowing on-site updates of PowerPoint presentations, if necessary.

All presentation files and CDs will be removed from the computers after each session finishes: any CDs not collected will be destroyed.

\section{Slide Presentations:}

Slides should be handed in at the Projection Center together with a completed 'Instructions for Projectionists' form at least 45 minutes before the session starts. However, it is strongly recommended that slides are delivered the day before the talk. Speakers should load slide trays themselves and are asked to check for correct slide orientation on one of the projectors in the Projection Center.

\section{Presentations using only Overheads}

Speakers using only overheads are also requested to hand in the "Instructions for Projectionists" form marked accordingly at the Projection Center. Speakers will manage the changing of overheads themselves. 


\section{INSTRUCTIONS FOR PROJECTIONISTS}

Please hand in this form at the Projection Center, together with your slides or the Powerpoint CD. Please do so also if you are using overheads only. CDs need to be turned in the day prior to the talk, slides may be provided no later than 45 minutes prior to the start of the session. We highly recommend, however, to deliver also slides the previous day. Please mark the CD with your name, symposium code, and the file name to be used.

Speaker

Symposium code:

date and time of talk

Please indicate slide sequence according to the example shown on the right. If your presentation is by Powerpoint or if you will show overheads only, please tick the respective box.

Powerpoint; File name on CD:

Overheads only

Please complete this table if you are using slides, or a combination of slides and overheads. Please load slide trays yourself and check correct slide orientation in the Projection Center

\begin{tabular}{|l|l|l|}
\hline time step & left screen & right screen \\
\hline 1 & & \\
\hline 2 & & \\
\hline 3 & & \\
\hline 4 & & \\
\hline 5 & & \\
\hline 6 & & \\
\hline 7 & & \\
\hline 8 & & \\
\hline 9 & & \\
\hline 10 & & \\
\hline 11 & & \\
\hline 12 & & \\
\hline 13 & & \\
\hline 14 & & \\
\hline 15 & & \\
\hline 16 & & \\
\hline 17 & & \\
\hline 18 & & \\
\hline 19 & & \\
\hline 20 & & \\
\hline 21 & & \\
\hline 22 & & \\
\hline 23 & & \\
\hline 24 & & \\
\hline 25 & & \\
\hline
\end{tabular}

\begin{tabular}{|c|c|c|}
\hline \multicolumn{3}{|l|}{ Example } \\
\hline time step & left & right \\
\hline 1 & 1 & 2 \\
\hline 2 & 3 & 4 \\
\hline 3 & 5 & | \\
\hline 4 & 6 & | \\
\hline 5 & 7 & 8 \\
\hline 6 & 9 & ----- \\
\hline 7 & $\mathrm{OH}$ & 10 \\
\hline
\end{tabular}

Slide 4 remains on screen in steps $3 \& 4$. The right screen is dark in step 6 . An overhead is shown on the left screen in step 7 (put up by the speaker). 


\section{FIELD TRIPS AND EXCURSIONS}

\section{Field Trips}

Nine field trips have been planned before and after Goldschmidt 2002. Bookings for these trips can be purchased from the Helpdesk while places remain.

\section{Pre-Conference Trips:}

Southern Steep Belt: Metamorphism and tectonic evolution of the Central Alps: A N-S profile.

(M. Engi and A. Berger)

\section{Ivrea Zone:}

Lower Crust, mafic underplating and tectonics. (J. Kramers)

\section{Pre-Conference Trips:}

Upper Pleistocene Chronologies: The last Glacial Maximum, Termination I and landscape evolution the need for absolute chronologies.

(Chr. Schlüchter, S. Ivy-Ochs, D. Florineth, P. Oberholzer and M. Maisch)

Prograde eclogite facies metamorphism and garnet peridotites of the Adula - Cima Lunga Nappe.

(V.M. Trommsdorff and C.A. Heinrich)

Carbonate platform drowning events and their geochemical signature.

(K. Föllmi)

The Platta-Malenco zone of exhumed continental mantle: Remnants of an embryonic oceanic basin.

(O. Müntener and J-R. Manatschal)

Field Geology, emplacement mechanisms, geochronology, and geochemistry of the Bergell intrusive suite.

(A. Berger and F. von Blanckenburg)

Three orogenies in the Alps.

(F. Bussy, U. Poller and U. Schaltegger)

Geomicrobiology Microbial life strategies under harsh environmental conditions and geochemical nutrient scavenging in nutrient-poor high mountain lake (Norbert Swoboda, Patricia Colberg, Barbara Sulzberger and Kurt Hanselmann)

\section{Tuesday Excursions}

Tuesday August 20th, 14:00 onwards

A range of activities are planned for Tuesday afternoon. No pre-booking is necessary: simply meet near the Helpdesk at 14:00. The cost of these activities will be less than 40 Euros.

- Geological excursion to the Flüelapass: Ordovician gneisses to Quaternary geology.

- Geological walk on the Totalp Serpentinite: Mantle petrology.

- Visit to the Mining Museum in the historical mining village of Monstein, with Silberberg Mine

- Visit to Research Projects in the Dischmatal, including UNESCO-MaB research area; $\mathrm{CO}_{2}$, water budget and ecological research.

- Visit to the Snow and Avalanche Research Institute

- Trip to the Weissfluhjoch

- Visit to the World Radiation Center

- Visit to the town of CHUR, offering the opportunity to be photographed next to the nameplate of this geochemically unique locality.

There will also be a delegates' football match (Brazilian delegates are especially welcome). 


\section{COMMITTEES}

Conveners:

Alex Halliday

Jan Kramers

Rainer Wieler

Secretary:

Valentina Mueller-Weckerle

Design and publicity:

Liz Ammann

Anke Poiger

Conference center and accommodation:

Davos Tourism

\section{Registration and Abstract submission Payments and field trip bookings Web-site design and maintenance} Circulars and electronic communications:

Cambridge Publications

\section{Goldschmidt Advisory Board:}

Al Hofmann

Bob Bodnar

Chris Hawkesworth

Francis Albarède

Judy McKenzie

Keith O,Nions

Max Coleman

Mike Drake

Mike Hochella

Terry Seward
Organizing Committee:

Chris Ballentine

Stefano Bernasconi

Mike Cosca

Christian de Capitani

Mike Dungan

Jost Eikenberg

Martin Engi

Albert Eschenmoser

Karl Föllmi

Martin Frank

Detlef Guenther

Stöff Heinrich

Jean Hernandez

Rocki Kipfer

Urs Krähenbühl

Bernhard Lehmann

Thomas Nägler

Thomas Peter

Don Porcelli

Mark Rehkämper

Urs Schaltegger

André Scheidegger

Christian Schlüchter

Diane Seward

Jorge Spangenberg

Claudine Stirling

Thomas Stocker

Alan Thompson

Peter Ulmer

Krisogono Vasconcelos Igor Villa

Friedhelm von Blanckenburg

Bernhard Wehrli

Helmi Weissert 


\section{COMMITTEES}

International Program Committee:

(chairs *)
Conel Alexander *
Yuri Amelin
Richard Arculus
Mike Arthur
Jeff Bada *
Jillian Banfield *
Vickie Bennett
Willy Benz

Stefano Bernasconi

Janne Blichert-Toft *

André Brack*

Sue Brantley *

Gordon Brown

Don Canfield

Marc Chaussidon

Mike Cosca

Jon Davidson

Bill Davison

Lou Derry

Patricia Dove

Mike Dungan

Katerina Edwards

Jost Eikenberg

John Eiler *

Martin Engi

Albert Eschenmoser

Ken Farley*

Martin Frank *

Jim Gill

Jamie Gilmour

Colin Graham

Detlef Guenther

Erik Hauri *

John Hayes *

Christoph Heinrich *

Gideon Henderson *

Peter Horn

Gerda Horneck

Emi Ito

Susan Ivy-Ochs

Balz Kamber

Kimitaka Kawamura

Simon Kelley

Roki Kipfer

Christian Koeberl

Ruben Kretzschmar

Walter Kutschera

Antonio Lazcano

Typhoon Lee

Bernhard Lehmann *

Craig Manning *

Chris McKay

Michel Meybeck

Walter Michaelis

Steve Mojzis

Wolfgang Müller*

Thomas Nägler

Eizo Nakamura

Dianne Newman

Erik Oelkers

Herbert Palme *

Julian Pearce *

Terry Plank

Don Porcelli *

Dieke Postma

Mark Rehkämper *

Paul Renne

Kevin Righter

Roberta Rudnick *

Sara Russell

Jörg Schaefer

Urs Schaltegger

André Scheidegger *

Dan Schrag *

Diane Seward

Terry Seward

Jorge Spangenburg

Hubert Staudigel

Holly Stein

Susan Stipp

Claudine Stirling

Claudine Stirling

Alan Stone

Yoshi Tatsumi

Matthew Thirlwall

Alan Thompson

Peter Ulmer *

Derek Vance

Chris Vasconcelos

David Vaughan Igor Villa

Friedhelm von Blanckenburg

Bernhard Wehrli *

Frances Westall

Uwe Wiechert

Anthony Williams-Jones

Bernie Wood *

Bruce Yardley

Ed Young

Marek Zreda 


\section{EXHIBITORS AND SPONSORS}

The organisers of Goldschmidt 2002 are grateful for the support of the following Sponsors and Exhibitors:

Actlabs (Booth 104)

ANALAB (Booth 306)

Australian Scientific Instruments (Booth 105)

Blackwell Science

Cambridge University Press

Cameca (Booth 304)

City of Davos

EPSL Frontiers

Elsevier Science (Booth 204)

ETH Zürich

The European Association of Geochemistry

The European Association of Organic Geochemists

The Geochemical Society (Booth 203)

The International Association of Geochemistry and Cosmochemistry

Jeol (Booth 102)

Leica

Micromass (Booth 303)

The Mineralogical Society of America

New Wave Research (Booth 307)

$\mathrm{Nu}$ Instruments (Booth 103)

Oxford University Press

Perkin Elmer

Picotrace (Booth 302)

Royal Society of Chemistry (Booth 202)

Schweizerbart'sche Verlagsbuchhandlung

Science magazine

Spectro Analytical Instruments (Booth 101)

Springer Verlag (Booth 201)

SWISS Airlines

Swiss National Science Foundation

Swiss Academy of Sciences SAS

ThermoFinnigan (Booth 305) 

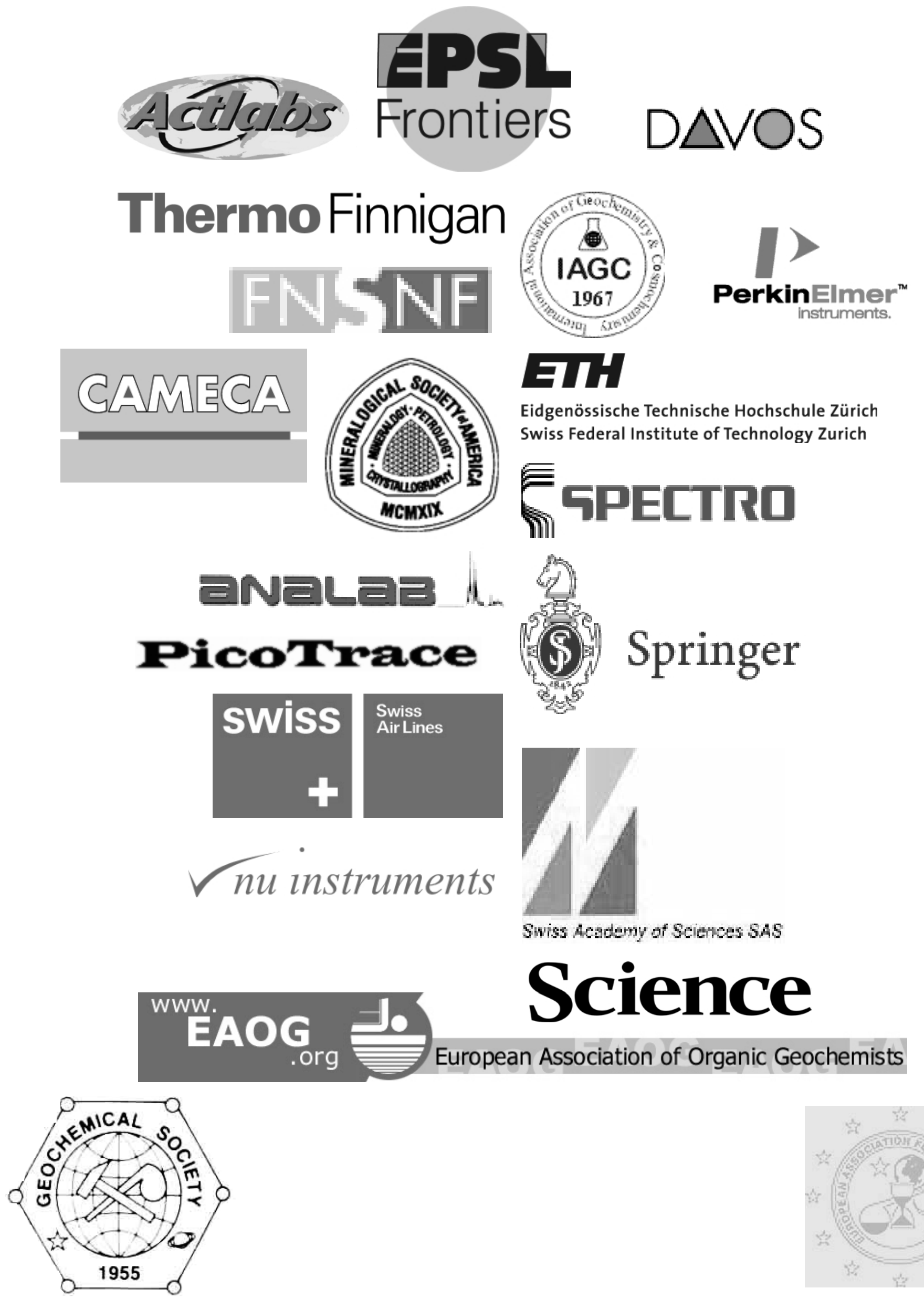


\title{
MEDALS AND AWARDS
}

\author{
The Urey Medal of the \\ European Association of Geochemistry \\ Grenville Turner
}

The V. M. Goldschmidt Medal of the

Geochemical Society

John M. Hayes

The Clarke Medal of the

Geochemical Society

Ruth Blake

The Outstanding Service Award of the Geochemical Society

Denis Shaw

The Patterson Medal of the

Geochemical Society

Harry Elderfield

EAG-GS Fellows

David Des Marais

Mike Drake

Irving Friedman

Cristopher Martens

Phil Meyers

Garrison Sposito

John Wasson 


\section{Presidential Address \\ A New Era for Isotope Geochemistry}

FRANCIS ALBAREDE

Ecole Normale Supérieure, Lyon 69007, France (albarede@ens-lyon.fr)

Until the advent of multiple-collector inductivelycoupled plasma mass spectrometry (MC-ICP-MS), only a small fraction of the periodic table was liable to precise isotopic analysis, and even then for most of the elements only the radiogenic, cosmogenic or nucleosynthetic part of isotopic variability was accessible. It was widely held that most heavy elements, with the exception of Se, were isotopically homogeneous and that most elements with only two isotopes such as $\mathrm{Cu}$ or $\mathrm{Ga}$ remained out of reach.

MC-ICP-MS started in the mid-90s under unfavourable auspices. Ion yields of about 50 ions per million atoms, a precision of hardly 0.02 percent, abundance sensitivity of several ppm and isobaric interferences deterred many users from shifting from TIMS to MC-ICP-MS. Over the following five years, this situation dramatically evolved: ion yields up to a few percent, precision down to $30 \mathrm{ppm}$ or even better, and interference control improved through collision cells, highresolution devices, or, simply, efficient chemical separation tipped the balance between the two techniques. New specifications on abundance sensitivity will very soon bring the isotope geochemistry of actinides within reach.

New radioactive isotopic systems benefited from this major technological advance: the revival of the ${ }^{176} \mathrm{Lu}-{ }^{176} \mathrm{Hf}$ chronometer with novel applications to the dating of garnetbearing rocks (eclogites, garnet peridotite) and phosphates is particularly important because of the apparently high closure temperature of the Lu-Hf system. A decisive advantage of this chronometric system in planetary sciences is that it is the only system together with $\mathrm{Sm}-\mathrm{Nd}$ for which both the parent and the daughter nuclides are incompatible lithophile refractory elements which allows planetary mass balance to be evaluated with more confidence than with for example $\mathrm{U}-\mathrm{Pb}, \mathrm{Rb}-\mathrm{Sr}$, or Re-Os. Application of this principle to the differentiation of the Earth, the Moon, Mars, and the eucrite parent body has proved to be particularly fruitful. A few radioactive systems involving extinct nuclides with refractory progeny also greatly benefited from the expansion of MC-ICP-MS. After the early success of ${ }^{182} \mathrm{Hf}-{ }^{182} \mathrm{~W}$ that helped clarify the chronology of core-mantle segregation in different planets, we are seeing a growing number of publications on ${ }^{97} \mathrm{Tc}-{ }^{97} \mathrm{Mo},{ }^{92} \mathrm{Nb}-{ }^{92} \mathrm{Zr}$, ${ }^{107} \mathrm{Pd}-{ }^{107} \mathrm{Ag}$, and now ${ }^{146} \mathrm{Sm}-{ }^{142} \mathrm{Nd}$.

The old U-Th- $\mathrm{Pb}$ system received a significant face lift: the precision of MC-ICP-MS $\mathrm{Pb}$ isotope data is currently better than $30 \mathrm{ppm}$ for all ratios that do not involve ${ }^{204} \mathrm{~Pb}$ and of 100-200 ppm for those that do, as a probable result of the poor abundance sensitivity of all the first-generation machines. This is, however, enough to demonstrate that the precision advertised so far for TIMS Pb isotope measurements was far too optimistic. It can be predicted that in the near future, MC-ICP-MS precision will break even with that of triple spike techniques $(<100 \mathrm{ppm})$, thus paving the way for further improvement in $\mathrm{U}-\mathrm{Pb}$ geochronology.

Some important principles underlying TIMS isotopic measurements do not transpose to the new technique. Since MC-ICP-MS is a steady-state instrument and samples are normally bracketed by standards, accuracy is no longer a prerequisite. In this respect, MC-ICP-MS isotope measurements borrow their principles from conventional stable-isotope techniques. A huge advantage is that mass discrimination can be precisely monitored even for elements with only two isotopes. This technique leads to considerable improvement on the precision on $\mathrm{Lu}$ (and presumably on $\mathrm{Rb}$ and $\mathrm{Re}$ ) for chronology and for $\mathrm{Cu}$ stable isotope geochemistry.

A new stable isotope geochemistry is born for a number of elements whose isotopic abundances so far remained poorly known or known only within the limits of double-spike measurements. It is remarkable that for decades stable isotope geochemistry had been largely restricted to the right-hand side of the periodic table. The isotopic compositions of metals such as $\mathrm{Cu}, \mathrm{Zn}, \mathrm{Fe}, \mathrm{Mg}$, are Mo are now routinely analyzed in several laboratories with a precision of 0.04 delta units. Massdependent $\mathrm{Zn}$ and $\mathrm{Fe}$ isotopic fractionation is well-behaved. In meteorites, these elements show amazingly large metalsilicate isotopic differences, while $\mathrm{Cu}$ may reveal some unsuspected nucleosynthetic effects. Seawater and biogenic carbonates are revealing isotopic variability for a number of elements such as $\mathrm{Zn}, \mathrm{Cu}, \mathrm{Fe}$, and Mo. Exciting controversies are popping out about possible isotope fractionation mechanisms, notably the potential of Fe isotope geochemistry to fingerprint biological effects. New experimentally controlled determinations of isotopic fractionation are desperately needed in large numbers. Modellers need to catch up with analysts to 'predict' these unpredicted phenomena.

The future of coupling laser ablation with MC-ICP-MS is hard to forecast. The statistics of measurements necessarily limit precision for small impacts and we may not expect particularly precise in situ $\mathrm{Nd}$ or $\mathrm{Fe}$ isotope measurements in any foreseeable future. In contrast, the prospect for the $\mathrm{U}-\mathrm{Pb}$ dating of zircons is bright. In general, it seems wise to keep matrix-spewing laser ablation applications separate from those needing clean instruments for solution work.

Isotopic tracers are simpler and more amenable to modelling and prediction than chemical tracers. We can anticipate that we are only seeing the beginning of the isotopic revolution. First, biology is not expected to remain immune to a new isotope geochemistry so obviously capable of establishing the economy and dynamics of metals in many living "things" at all scales of living biota. Second, painstaking isotopic measurements on rock samples that used to be the privilege of a few specialized laboratories are bound to become abundant and their quality, probably after a teething period, to improve drastically. The new frontiers are the sample size (sensitivity) and the elimination of isobaric interferences, notably in the perspective of the return of planetary samples. 


\title{
Gast Lecture
}

\section{Deciphering the physical basis of biomineralization through the lens of mineral assembly}

\author{
P.M. Dove ${ }^{1}$, K.J. DAvis ${ }^{2}$, J.J. DeYoreo ${ }^{3}$, C.A. ORME ${ }^{3}$, M.C. GRANTHAM ${ }^{4}$, H.H. TENG ${ }^{5}$, \\ M. VELAZQUEZ ${ }^{1}$, A. WIERZBICKI ${ }^{6}$ AND D.S. WILSON ${ }^{1}$
}

${ }^{1}$ Department of Geosciences, Virginia Tech, Blacksburg, VA 24061 USA (dove@vt.edu; mv@ vt.edu; dawilso5@vt.edu)

${ }_{3}^{2}$ Department of Geology and Geophysics, Rice University, Houston, TX 77005 USA

${ }^{3}$ Chemistry and Materials Sciences, LLNL, Livermore, CA 94025 USA (deyoreo1@1lnl.gov; orme1@1lnl.gov)

${ }_{5}^{4}$ School of Earth and Atmospheric Sciences, Georgia Tech, Atlanta, GA 30332 USA (grantham@eas.gatech.edu)

5 Department of Geology, George Washington University, Washington, D.C. USA (hteng@gwu.edu)

${ }^{6}$ Department of Chemistry, University of South Alabama, Mobile, AL 36688 USA

Over the course of Earth history, organisms have developed the ability to produce single crystal and composite materials with remarkable properties that fulfil specific functional needs. Using biologically mediated crystallization strategies, aqueous solutes are organized into mineralized structures with nanoscale to macroscopic dimensionalities. Although biomineral compositions and morphologies are signatures that may be used to decipher environments of prosperity and decline, most current interpretations lack an understanding of fundamental processes.

Recently, the biomineralization activities of marine microorganisms have emerged as particularly important owing to the use of biomineral products as paleoclimate indicators. In addition to providing critical information on crystal growth history, the minor and trace elements contained in biominerals also behave as impurities to regulate their properties and formation rates. We can begin to unravel this complexity by recognizing that mineralization is, above all, a thermodynamic phase transition. Using integrated approaches, we are investigating the kinetics and thermodynamics of $\mathrm{CaCO}_{3}$ growth as a simple model system to decipher mechanisms of biomineral formation. Our focus is to understand the surface processes that govern growth of nanoscale structures, their chemical compositions, and how these growth structures interact to yield complex mineralized morphologies.
By combining in situ AFM studies of growth that use characterized solution chemistries with molecular modeling and surface spectroscopy, we link observations of nanoscale growth mechanisms with quantitative kinetic and thermodynamic information. We have established growth thermodynamics for the $\mathrm{CaCO}_{3}-\mathrm{NaCl}$ and now the $\mathrm{CaCO} 3$ synthetic seawater systems to show how key inorganic impurities affect mineralization through complex ionspecific mechanisms.

We also show how simple amino acids affect growth by modifying the energetics of step edges to produce mirrorimaged growth structures that reflect the chirality of bioactive compounds. In new work, we are investigating the interactions of simple peptides with the calcite surface as a simple model system for understanding roles of the more complex matrix proteins in mineralization.

A central theme that has emerged from our studies is the importance of steps. Existing crystal growth models have proposed that stereochemical recognition of impurities for particular faces causes stabilization of those faces while largely ignoring the roles of step-edge structures and their specificities for reaction. Our findings demonstrate that morphological evolution is defined by nanoscale impuritystep interactions. 


\title{
V. M. Goldschmidt Medallist Lecture Isotopic Order, Biogeochemical Processes, and Earth History
}

\author{
JOHN M. HAYES
}

Department of Geology and Geophysics, Woods Hole Oceanographic Institution, Woods Hole, MA 02543, USA

(jhayes@whoi.edu)

\begin{abstract}
Abundances and distributions of the isotopes of carbon vary on temporal, spatial, and chemical dimensions. The latter include variations within compounds, between compounds, between classes of compounds, and between organic and inorganic phases. An information theorist, thinking in terms of the number of channels available, would conclude that the capacity of such a system to encode and preserve data about processes and environments is very large. Moreover, that capacity grows exponentially as signals carried by the isotopes of $\mathrm{H}, \mathrm{N}, \mathrm{O}$, and $\mathrm{S}-$ not discussed here - are considered.

The scientific landscape combining organic and isotopic geochemistry, cellular biochemistry, and microbial ecology is indeed proving fertile. One of the catalysts for this productivity has been the development of new techniques of isotopic analysis (Matthews and Hayes, 1978; Merritt et al., 1995). The combination of structural and isotopic lines of evidence reveals relationships between compounds and leads to process-related thinking. These are large steps. Reconstruction of the sources and histories of molecular fossils redeems much of the early promise of organic geochemistry by resolving and clarifying paleo-environmental signals. In turn, contemplation of this new information is driving geochemists to study microbial ecology, oceanography, and sedimentology.
\end{abstract}

The impetus to interpret carbon isotopic signals comes from an understanding of isotopic fractionations imposed by living organisms. That understanding rests in turn on studies of enzymatic isotope effects (DeNiro and Epstein, 1977; Farquhar et al., 1989), on fruitful concepts of isotopic order (Galimov, 1981), and on studies of the distribution of ${ }^{13} \mathrm{C}$ both between and within biosynthetic products (Monson and Hayes, 1982a; 1982b; Hayes, 2001). In sum, these studies have shown that the isotopic compositions of biological products are governed by reaction kinetics and by pathways of carbon flow. This point is exemplified most elegantly by studies of isotopic fractionations in algal photosynthesis (Laws et al., 2002).

Isotopic compositions of individual compounds can indicate specific processes or environments. Examples include the use of methane as a carbon source (Freeman et al., 1990 Hinrichs et al., 2000) and the existence of a zone in which, most unusually, light is available for photosynthesis but $\mathrm{O}_{2}$ is absent (Summons and Powell, 1987; Hartgers et al., 1994). In each case, the molecular-isotopic signal is definitive, indicating the availability of $\mathrm{CH}_{4}$ or profound stratification of a water column. As shown by Timothy Eglinton and coworkers, analyses of ${ }^{14} \mathrm{C}$ in organic compounds provide additional information. Radiocarbon ages of specific compounds can reflect the time since biosynthesis, the ${ }^{14} \mathrm{C}$ content of the initial carbon source, or - by comparison to other age indicators -the age of the compound at its time of deposition (Pearson et al., 2001).

By all of these means, our ability to reconstruct the history of life and its role in the development of the planetary environment is growing rapidly. Given a chance, our successors will probably get it right.

\section{References}

DeNiro M. J. and Epstein S. (1977) Science 197, 261-263.

Farquhar G. D., Ehleringer J. R., and Hubick K. T. (1989) Annu. Rev. Plant Physiol. Plant Mol. Biol. 40, 503-537.

Freeman K. H., Hayes J. M., Trendel J.-M., and Albrecht P. (1990) Nature 343, 254-256.

Galimov E. M. (1981) The Biological Fractionation of Isotopes, Nauka, Moscow, 247 pp. [English translation, Academic Press, London, 1985]

Hartgers W. A., Sinninghe Damsté J. S., Requejo A. G., Allan J., Hayes J. M., Ling Y., Xie T-M., Primack J., de Leeuw J. W. (1994) Org. Geochemistry 22, 703-725.

Hayes, J. M. (2001) pp. 225-278 in Valley J. W. and Cole D. R. (eds.) Stable Isotope Geochemistry, Revs. Mineral. \& Geochem. 43, Mineral. Soc. Amer.

Hinrichs K.-U., Summons R. E., Orphan V., Sylva S. P., and Hayes J. M. (2000) Org. Geochem. 31, 1685-1701.

Laws E. A., Popp B. N., Cassar N., and Tanimoto J. (2002) Functional Plant Biol. 29, 323-333.

Matthews D. E. and Hayes J. M. (1978) Anal. Chem. 50, 1465-1473.

Merritt D. A., Freeman K. H., Ricci M. P., Studley S. A., and Hayes J. M. (1995) Anal. Chem. 67, 2461-2473.

Monson K. D. and Hayes J. M. (1982a) Geochim. Cosmochim. Acta 46, 139-149.

Monson K. D. and Hayes J. M. (1982b) J. Biol. Chem. 257, 5568-5575.

Pearson A., McNichol A. P., Benitez-Nelson B. C., Hayes J. M., and Eglinton T. I. (2001) Geochim. Cosmochim. Acta 65, 3123-3137.

Summons R. E. and Powell T. G. (1987) Geochim. Cosmochim. Acta 51, 557-566. 


\title{
Urey Medallist Lecture \\ In Praise of Idleness
}

\author{
GRENVILLE TURNER
}

Department of Earth Sciences, University of Manchester, Manchester M13 9PL, UK. grenville.turner@man.ac.uk

My title comes from a collection of essays by Bertrand Russell ${ }^{1}$ but is actually intended as an oblique reference to the noble gases and in particular argon (Greek argos $=$ idle). Study of the noble gases, often in conjunction with neutron irradiations which yield noble gas products, has an important place in isotope geochemistry and, for the main thread of my talk, in cosmochemistry.

Noble gases are playing a part in advancing our knowledge in several important problem areas in cosmochemistry; the details of heavy element synthesis and of processes in the interstellar medium from a study of interstellar grains; the time scale of solar system formation and the reconciliation with astrophysical models; the search for evidence of early solar activity (particle irradiation, stellar outflows) from isotopic effects in the earliest formed solids; the history of water in the solar system; the evolution of the martian interior and atmosphere; the evolution of life on Earth and the search for life elsewhere; the history of impacts on the Earth and their implications for the future.

These problems demand the development of new techniques directed to the ultimate analytical goal of isotope geochemistry, the detection of each and every atom of each isotope in the sample, free from blank contamination, with a spatial resolution limited only by the need to obtain appropriate counting statistics. This goal is being approached for several elements including the noble gas xenon. Using resonance ionisation it is now possible to determine I-Xe age profiles in a manner similar to the Ar-Ar laser probe. With detection limits of a few tens of atoms of $\mathrm{Xe}$ it should soon be possible to determine the nucleosynthetic structures of Xe in individual pre-solar SiC grains. Although dominated by s-process xenon, SiC contains an r-process component which is distinct from that in the solar system. The so called xenon-HL component was used in the isolation of nano-diamonds but the extent to which these are really pre-solar is still not clear. Xenon, present in only one nano-diamond in a million, cannot resolve this question and techniques need to be developed to manipulate, atomise and ionise all the atoms in individual nano-diamonds to search for non-solar system carbon isotope ratios. As with the Apollo programme, it is likely that the new generation of extraterrestrial sample return missions will stimulate a new range of technical advances. The 'atom counter' for elements across the periodic table may not be far away

After decades of uncertainty, significant advances have been made in recent years in obtaining I-Xe ages which are both accurate and meaningful. This has come about partly through the use of separated minerals and partly through a better understanding of the factors affecting I-Xe systematics. The possible mobilisation of 'dead' iodine and/or 'parentless' ${ }^{129} \mathrm{Xe}$ leads to subtle differences in comparison with $\mathrm{K}-\mathrm{Ar}$ systematics. I-Xe ages can be related to chondrule formation, presumed by many to be a primary nebular processes. In the equilibrated meteorites I-Xe ages provide a time scale of secondary recrystallisation and in particular, the growth of secondary feldspar and apatite. The formation times of the refractory CAI are not susceptible to I-Xe dating. In general I-Xe ages of these complex objects reflect later alteration and the formation of secondary minerals such as sodalite. Most recently I-Xe ages of microgram crystals of halite containing aqueous fluid inclusions have demonstrated the presence of liquid water on proto-planetary bodies within a few million years of formation of the solar system. Time scales based on shortlived 'extinct' isotopes are relative but significant progress has been made in linking these relative time frames of I-Xe, $\mathrm{Al}-\mathrm{Mg}$ and $\mathrm{Mn}-\mathrm{Cr}$ to each other and to the absolute $\mathrm{U}-\mathrm{Pb}$ scale. The picture which emerges is of chondrule formation, early igneous activity, aqueous and other alteration processes overlapping in the first 5-10 Ma, and postdating the earliest formation of CAI by no more than $2 \mathrm{Ma}$.

A spin off from advances in I-Xe dating is the ability to measure iodine abundances at sub ppb levels in microgram samples, while stepped heating permits the separation of insitu iodine from surface contamination. In the Earth's crust iodine is concentrated predominantly in sediments as a result of biochemical processes. The ability to measure iodine distribution at a microscopic level promises a way of investigating the evolution of iodine biochemistry and more generally of early life. If iodine biochemistry is a feature of extraterrestrial life it may be a potential biomarker.

The major technical advances in Ar-Ar dating have been in the use of laser ablation, to reduce blank levels and hence sample size and minimum sample age, and in the ubiquitous computer automation. However, in contrast to xenon (and krypton), the underlying mass spectrometry techniques have changed little in 40 years. That may be about to change with the development of the compressor ion source and the first multi-collector noble gas instrument. Neutron reactions on the halogens have proved to be a useful extension of the ArAr methodology where noble gases are associated with saline fluids, in samples as diverse as diamonds and ore minerals. Neutron reactions on tellurium, producing ${ }^{131} \mathrm{Xe}$, are also providing a method for dating telluride ores based on the $10^{20} \mathrm{yr}$ double $\beta$-decay half life of ${ }^{130} \mathrm{Te}$.

An intriguing puzzle, which dates back almost forty years to the very earliest Ar-Ar work, is the significance of the clustering of outgassing ages of the common Lchondrites at around 400 to $500 \mathrm{Ma}$. The heating required to produce widespread Ar loss in a high proportion of Lchondrites seems to require the break-up of a major asteroidal body with whatever that may have entailed for the recent bombardment history of the Earth!

${ }^{1}$ Russell B. (1935) In Praise of Idleness and Other Essays, Unwin Books, London, 144p 


\section{xxvi}




\section{Goldschmidt 2002}

PROGRAMME 


\section{Geochemistry and Mineral Physics}

\section{Convenors:}

\section{Max Schmidt \& Martin Kunz}

08:30 Hu R, Zhao J, Peng J, Bi X, Farley KA \& Burnard P:

Mantle-derived Components in Xiangshan Uranium Deposit, Jiangxi, China

08:45 Liu J, Zheng M, Long X, Wang J \& Li E:

Sawaya'erdun Gold Deposit - The First Example of Chinese Muruntau-type Gold Deposit

09:00 Wen H \& Qiu Y:

Occurrence of Selenium in the Kerogen-Evidences of TEM

09:15 Bi X \& Hu R:

REE and $\mathrm{Sr}$, Nd Isotopic Geochemistry of Alkaline Intrusion Related to $\mathrm{Au}$ and $\mathrm{Cu}$ Mineralization in Ailaoshan - Jinshajiang Alkaline Intrusive Belt, Southwestern China

09:30 Helmy H.

Volcanogenic Massive Sulfide (VMS) Deposits from the Eastern Desert of Egypt: A Comparative Mineralogical and Geochemical Study

09:45 Turku A:

PGE Concentration within Sulphide Mineralization Related to Ophiolite Volcanic Sequence

N 10:00 Evstigneeva TL, Merkle RK \& Trubkin NV:

Crystallisation of PGE Sulpharsenides from Sulphide Melt

10:15 Fleet M, Liu X \& King P:

Carbonate Apatite at High Pressure

10:30 Gartvich J \& Surkov NV:

Clinopyroxene Geothermobarometer for Eclogites

10:45 Litasov K \& Ohtani E:

Melting Relations of Pyrolite in CMAS- $\mathrm{H}_{2} \mathrm{O}$ System up to $25 \mathrm{GPa}$

11:00 Chen J, Inoue T, Yurimoto H \& Weidner D:

Water and 410-km Seismic Discontinuity: Experimental Results of Water Effect on Olivine-Wadsleyite Phase Transition in $(\mathrm{Mg}, \mathrm{Fe})_{2} \mathrm{SiO}_{4}$ System

11:15 Dubrovinskaia N \& Dubrovinsky L:

High-Temperature Heater for Diamond-Anvil Cells

11:30 Xue X, Kanzaki M \& Fraser D:

The Dissolution Mechanisms of Forsterite and Enstatite: Constraints from ${ }^{29} \mathrm{Si}$ and ${ }^{1} \mathrm{H}$ MAS NMR

11:45 Savenko A:

Experimental Modeling of Strontium Coprecipitation with $\mathrm{CaCO}_{3}$ in the River Water-Seawater Mixing Zone

\section{Symposium S01}

\section{Presolar Grains and Gases}

\section{Convenors:}

\section{Uli Ott \& Larry Nittler}

08:30 Sandford S:

KEY Presolar/Interstellar Materials

09:00 Jones A:

INV Grain Formation, Processing and Survival in, and Transport Through, the ISM

09:15 Zinner E, Amari S, Guinness R, Ann N \& Stadermann F:

INV Isotopic Compositions of Small Presolar Dust Grains

09:30 Hoppe P:

INV Extinct Radioactivities in Presolar Silicon Carbide Grains of Type $\mathrm{X}$

09:45 Davis A, Pellin M, Tripa E, Savina M, Lewis R \& Clayton R:

INV Multielement Analyses of Single Presolar SiC Grains from Supernovae

10:00 Nittler $L$ :

EPSL Frontiers Lecture: Towards a Unified Understanding of Presolar SiC Grain from AGB Stars

10:15 Turner G \& Gilmour J:

INV A 3D Approach to Xenon Isotopes in Interstellar Grains

10:30 Paul M, Feldstein C, Valenta A, Ahmad I, Nakanishi T \& Sakamoto K:

An Insight into ${ }^{244} \mathrm{Pu}$ Abundance in Interstellar Matter

10:45 Snow TP:

INV Element Segregation during Star Formation

11:00 Charnley S:

INV Interstellar Organic Chemistry

11:15 Ehrenfreund P, Ruiterkamp R, Botta O, Peeters Z \& Foing B:

INV Complex Organics and Prebiotic Molecules in Space

11:30 Robert F:

INV Water and Organic Matter D/H Ratios in the Solar System: A Record of an Irradiation of the Nebula?

11:45 Mumma M

INV Chemical Diversity Among Comets: Implications for Delivery of Water and Prebiotic Organics to Early Earth

12:00 Cody G, Alexander C \& Tera F:

INV The Chemical Origins and Evolution of Organic Matter in Carbonaceous Chondrites

12:15 Bradlev

INV Interplanetary Dust Particles 
Archean and Proterozoic Oceans, Climates, and Geochemistry

\section{Convenors: Balz Kamber, Dan Schrag, Minik Rosing \& Don Canfield}

\section{8:30 Kramers JD:}

INV Volatile Element Abundances Point to a $\mathrm{H}_{2} \mathrm{O}$ Ocean on Earth at $>4.4 \mathrm{Ga}$

08:45 Rosing MT \& Frei R:

$>3700 \mathrm{Ma}$ Oxidized Ocean Water, Pb Isotopic Evidence from Isua, West Greenland

09:00 Schoenberg R, Kamber BS, Collerson K \& Moorbath $S$ :

INV Evidence for $\sim 3.8 \mathrm{Ga}$ Meteorite Bombardment of the Earth

09:15 Cavosie A, Valley JW, Fournelle J \& Wilde SA:

Implications for Sources of Jack Hills Metasediments: Detrital Chromite

09:30 Des Marais D:

INV Biogeochemical Carbon Cycles during the Archean and Early Proterozoic

09:45 Bjerrum C.J \& Canfield DE:

Carbon Isotope Model of the Archean: Significance of Deep Ocean Carbonate Precipitation

10:00 Westall F \& Marchesini D

Early Archaean Microbial Biofilms and their Influence on Volcaniclastic and Chemical Sedimentation

10:15 Lepland A, van Zuilen M \& Arrhenius G:

Origin and Biologic Significance of Graphite and Apatite in Early Archean Supracrustal Rocks from Isua Belt and Akilia Association

10:30 Whitehouse MJ \& Fedo CM:

INV Early Archean Life-bearing Ocean or Shear Zone? - Akilia Re-evaluated

10:45 van Zuilen M, Lepland A \& Arrhenius G:

Graphite and its Isotopic Composition as a Biomarker in Highly Metamorphosed Early Archean Rocks

11:00 Brasier M, Green O, Jephcoat A, Kleppe A, Van Kranendonk M \& Lindsay J:

KEY Questioning the Evidence for Earth's Oldest Fossils

11:30 Bosak T \& Newman D:

Microbial Biofilms: The Implications for Stromatolite Morphogenesis

11:45 Grassineau N, Nisbet $E$ \& Fowler $M$ :

Studies of Archaean Prokaryotic Mat Ecology, Belingwe Belt, Zimbabwe

12:00 Loukola-Ruskeeniemi K:

Extensive C- and S-rich Black Shale Formations: Abundant Life Around Black Smokers 2 Ga Ago

(Symposium S07 Continued in Session 18pm on Page 8)
Symposium S13

Room C/A2

\section{Subduction Factory: From Ocean to Mantle}

\section{Convenors:}

\section{Derrill Kerrick \& Peter Ulmer}

08:30 Kerrick D \& Connolly J:

Quantification of Subduction Zone Metamorphic Devolatilization from Computed High Pressure Phase Equilibria

08:45 Vervoort JD, Plank T, Patchett PJ \& Söderlund U:

The Lu-Hf-Nd Isotopic Signature of Subducting Pelagic Sediments

09:00 Dählmann A, de Lange GJ \& Haese RR:

Mineral Dehydration at Eastern Mediterranean Mud Volcanoes: Evidence from Stable Isotope Analyses

09:15 Gao Y, Hoefs J \& Snow J:

Oxygen Isotope Profile of the Lower Ocean Crust: An In-situ Study by UV-laserablation Oxygen Isotope Microprobe

09:30 Peucker-Ehrenbrink B, Bach W \& Hart SR:

Os, Ir, Pt, Pd and Re in Hole 504B

09:45 Mottl MJ, Komor SC, Fryer P \& Scientific Party of ODP Leg 195 :

Deep Fluids from the Subducting Pacific Plate and Associated Extremophilic Microbial Activity on a Mariana Forearc Serpentine Seamount, ODP Leg 195

10:00 Busigny V, Cartigny P, Philippot $P$ \& Javoy M: Geochemistry of $\mathrm{K}, \mathrm{Rb}, \mathrm{Cs}, \mathrm{N}$ and $\delta^{15} \mathrm{~N}$ in Metasediments of a Cold Subduction Zone: Implication on Fluid Circulation

10:15 Zack T, Tomascak P, McDonough W, Rudnick R \& Dalpe C:

Evidence for Li Isotope Fractionation during Subduction

10:30 Leeman W, Huang S \& Tonarini S:

Comparative Thermal Models for Subduction Zones: Evaluation of Slab Contributions to Volcanic Arc Magmas

10:45 Tatsumi Y:

Genetic Linkage between Calc-alkalic Andesites and Continental Crusts

11:00 Kleinhanns I, Kramers J \& Kamber B:

$\mathrm{H}_{2} \mathrm{O}$ in the Mantle Drives Secular Change in Continetal Petrology

11:15 Rüpke L, Phipps Morgan J \& Hort M:

Does Slab Serpentinization and Deserpentinization Create the Primary HIMU Mantle Component?

11:30 Berly T, Hermann J, Arculus RJ \& Lapierre H:

Metasomatic Origin of Pyroxenites in the Solomon Islands

11:45 Mungall JE:

Oxidation of the Mantle Wedge 
Room C/A1

Trace Element Fingerprinting: Laboratory Studies and Petrogenetic Processes

\section{Convenors:}

\section{Sue O’Reilly \& Ricardo Vannucci}

08:30 Wood B.J \& Blundy JD:

Trace Element Partitioning - New Developments Building on the Lattice Strain Model

08:45 Brooker R, Wood B, Kelley S, Chamorro E \& Blundy J:

The 'Zero Charge' Partitioning Behaviour of Noble Gases during Mantle Melting

09:00 Li C \& Ripley EM:

The Effect of Ni-S Speciation on Nickel Partitioning in Olivine

09:15 Brenan J, Dalpe C \& McDonough W:

PGEs are Fractionated by Olivine-melt Partitioning

09:30 Tiepolo M, Oberti R \& Vannucci R:

Structural Constraints to $\mathrm{Nb}$ and Ta Incorporation in Minerals

09:45 Woodland AB, Seitz H, Yaxley GM \& Altherr R:

$\mathrm{Li}$ as an Indicator of Petrogenetic Processes in the Earth's Mantle

10:00 Gregoire M, Bell DB \& Le Roex AP:

Mafic and Ultramafic Xenoliths from the Kaapvaal Craton (South Africa): Trace Element Evidence for Mantle Magmatic and Metasomatic Processes

A 10:15 Moine BN, Sheppard SM, O'Reilly SY, Gregoire M, Delpech G \& Renac C:

Carbonate Melt in Oceanic Mantle: Evidence from Kerguelen Mantle Xenoliths

10:30 Paquin J, Mason PR \& Altherr R:

The Individual Behaviours of Trace Elements in the Orogenic Alpe Arami Garnet Peridotite (Central Swiss Alps). A Detailed LA-ICPMS Study

10:45 Bonadiman C, Beccaluva L, Coltorti M \& Siena F:

Garnet-spinel Subsolidus Re-equilibration and K-metasomatism in Cape Verde Lithospheric Mantle

11:00 Coltorti M, Beccaluva L, Bonadiman C, Faccini B, Ntaflos T \& Siena F:

Relationships between Ti-rich Alkali Silicate Metasomatism and Amphibole, Glass and Clinopyroxene Genesis in Mantle Xenoliths from Antarctica, Australia and Austria

11:15 Humayun M, Puchtel IS \& Brandon AD

PGEs in Icelandic Picrites

11:30 Rapp RP \& Shimizu N:

A Genetic Relationship between Archean TTG Granitoids and Eclogitic and Peridotitic Xenoliths from the Subcratonic Mantle? Experimental Evidence at 2$4 \mathrm{GPa}$

\section{Symposium S33}

Room B/Pi

The Deep Biosphere - Microbial Communities in Deeply Buried Media

Convenors:

Tim Ferdelman, Tommy Phelps \& Andreas Teske

08:30 D’Hondt S, Jørgensen B, Blake R, Dickens G, Hinrichs K \& Holm N:

KEY Microbial Activity in Deeply Buried Marine Sediments

09:00 Spivack A \& Smith D:

INV Hydrogen Concentrations in Deeply Buried Marine Sediments: Determination of Concentrations and Utilization Rates

09:15 Horsfield B, Dieckmann V, Mangelsdorf K, Di Primio R, Wilkes H \& Schloemer S:

INV Organic Diagenesis: A Potential Provider of Substrates for Deep Microbial Ecosystems

09:30 Kallmeyer J, Ferdelman TG, Joergensen BB \& ODP Leg 201 Shipboard Party :

Sulfate Reduction Rates in Deeply Buried Marine Sediments

09:45 Toffin L \& Prieur D:

INV Cultivable Microbial Populations in Deep Marine Sediments

10:00 Cypionka H, Engelen B \& Sass H:

INV Novel Approaches to the Cultivation of Marine Sediment Bacteria

10:15 Takai K:

INV Possible Occurrence of Hyperthermophilic Subsurface Lithoautrophic Microbia Ecosytem (HyperSLiME) in Subvent Biosphere

10:30 Banerjee NR \& Muehlenbachs K:

Bioalteration in a Subseafloor Tuff - The Link between Rocks and Sediments

10:45 Sherwood Lollar B, Ward J, Slater G, Lacrampe-Couloume G, Lin L \& Onstott T:

Hydrogen and Hydrocarbon Gases in Crystalline Rock: Implications for the Deep Biosphere

11:00 Lin L, Onstott T, Lippmann J, Ward J, Hall J \& Sherwood Lollar B:

Radiolytic $\mathrm{H}_{2}$ in Continental Crust: A Potential Energy Source for Microbial Metabolism in Deep Biosphere

11:15 Bach W:

INV Energy for Chemoautotrophs in Mid-ocean Ridge Flanks

11:30 Neretin LN, Schippers A, Teske A, Ferdelman T, Joergensen BB \& Leg 201 Shipboard Scientific Party :

INV Quantitative Molecular Techniques to Study the Abundance and Activity of Microorganisms in the Marine Deep Subsurface

11:45 Inagaki F, Okada H, Tsapin A, Nealson K \& Horikoshi K:

INV Endolithic Genetic Record of Ancient Microbes in Cretaceous Black Shale

12:00 Dickens G:

INV The Effects and Implications of Anaerobic Methane Oxidation on the Geochemical Cycling of Barium in Marine Sediment 


\section{Ocean Circulation: Past and Present}

\section{Convenors:}

Catherine Jeandel, Jess Adkins \& Ian Hall

08:30 Marchitto T \& deMenocal P:

KEY Upper North Atlantic Deep Water Variability during the Holocene

09:00 van de Flierdt T, Frank M, Lee D, Halliday AN, Günther D \& Hein JR:

Present and Past Export of Southern Ocean Deep Water to the Pacific

09:15 Rutberg R, Goldstein S \& Hemming S:

Agulhas Leakage Variability from Sr Isotopes in South Atlantic Detritus

09:30 Staubwasser M \& Henderson GM:

${ }^{238,234} \mathrm{U},{ }^{232},{ }^{230} \mathrm{Th},{ }^{226} \mathrm{Ra}$, and $\mathrm{Ba}$ in Holocene Marine Carbonate and its Potential for Age-dating

09:45 Chu N, German C, Nesbitt R, Van de Flierdt T, Frank M \& Kubik P: Decoupling of $\mathrm{Hf}$ and Nd Isotopes in Western Pacific Fe-Mn Crusts

10:00 Asahara Y, Lee D, Frank M, van de Flierdt T, Halliday A \& Nishimura A:

Hf-Nd Isotopic Variations of Authigenic and Silicate Components in North Pacific Sediments

10:15 Schmidt M, Spero H \& Lea D:

Temperature and Hydrological Changes in the Western Caribbean during the Last Glacial Cycle

10:30 Chavagnac V, German CR \& Cave RR:

The Record of the Hydrothermal Activity at Rainbow (MAR, $36^{\circ} 14^{\prime} \mathrm{N}$ ) by Sediment Cores

10:45 Frank M, Porcelli D, Andersson P, Halliday AN, Kubik PW \& Hattendorf B: The Behaviour of ${ }^{10} \mathrm{Be}$ and ${ }^{9} \mathrm{Be}$ in the Arctic Ocean: Relationship to Water Mass Distribution and Particle Flux

11:00 Lacan F \& Jeandel C:

NADW Formation Traced by Nd Isotopic Ratios

11:15 Robinson LF \& Henderson GM:

Th, Pa and U Isotopes in Bahamas Seawater by MC-ICP-MS

11:30 Hanfland C \& Rutgers van der Loeff MM:

Decoupling of ${ }^{226} \mathrm{Ra}$ and $\mathrm{Si}$ in the Atlantic Sector of the Southern Ocean

11:45 Luz B \& Barkan E:

Tracing Mixing in the Upper Ocean with the Three Oxygen Isotopes

\section{Symposium S44}

Room A/St

Recent Advances in ICPMS and High-precision Isotope Ratio Mass Spectrometry

Convenors: Mark Rehkämper, Steve Galer \& Dieter Garbe-Schönberg

08:45 Freedman PA:

INV Mass Bias in ICP Mass Spectrometers

09:00 Thirlwall MF, Anczkiewicz R, Vance D \& Munday D:

INV Accuracy and Long-term Precision of MC-ICP-MS Isotope Ratios

09:15 Baker J \& Waight T:

$\mathrm{Pb}$ Isotope Analysis using $\mathrm{Tl}$ and $\mathrm{a}^{207} \mathrm{~Pb}-{ }^{204} \mathrm{~Pb}$ Spike on a Double Focusing MC ICPMS

09:30 Xie Q, Liu S, Pan Y \& Shao H:

Mass Discrimination in MC-ICP-MS: Example from $\mathrm{Cu}-\mathrm{Zn}$ Isotopes

09:45 Halicz L \& Ehrlich S:

Precise Isotope Ratio Analysis by MC-ICP-MS Without Matrix Separation - Sr, Pb and U Case Study

10:00 Günther-Leopold I, Wernli B \& Kopajtic Z

Isotope Ratio Measurements on Transient Signals by an Online Coupled HPLCMC-ICP-MS System

10:15 Hattendorf B, Schönbächler M \& Günther D:

INV Interference Reduction by Ion-molecule Reactions in ICP-MS. Chemical Resolution for the Earth Sciences

10:30 Wever S \& Schwieters JB:

Advances in Stable Isotope Measurements with High Mass Resolution MC-ICPMS

10:45 Halliday AN, Freedman P, Oberli F, Baur H, Hollins S \& Levasseur S:

INV Nu 1700: A New Large-geometry High-resolution Multiple Collector ICP-MS

11:00 Bouman C, Vroon P, Elliott T, Schwieters J \& Hamester M:

Determination of Lithium Isotope Compositions by MC-ICPMS (Thermo Finnigan MAT Neptune)

11:15 Vroon P, Beets C, Soest R, Schwieters J, Troelstra S \& Belle Jv:

Silicon Isotopic Composition of Sponge Spicules Determined by MC-ICPMS

11:30 Woodland S, Rehkämper M, Lee DC \& Halliday A:

High Precision MC-ICPMS Measurement of Ag Isotopic Ratios

11:45 Klaue B, Lauretta DS \& Blum JD:

Mercury in Carbonaceous Chondrites

(Symposium S44 Continued in Session 18pm on Page 10) 
Novel Approaches and New Techniques in Dating Minerals, Rocks, and Geological Processes

\section{Convenors:}

Igor Villa \& Holly Stein

08:30 Kriegsman LM:

Where is Geochronology Going? Migmatite Petrology and Isotope Transport

08:45 Whitehouse MJ:

Where is Geochronology Going? Dating the Processes Behind Zircon Microstructures

09:00 Seydoux-Guillaume A, Wirth R, Deutsch A \& Scharer U:

On the Importance of the Microstructure for Understanding U-Pb Ages of Dating Minerals

09:15 Lee M, Cayzer N \& Parsons I:

Where is Geochronology Going? Insights into Intracrystalline Reactions from Alkali Feldspars

09:30 Villa IM:

Where is Geochronology Going? Alteration and Mineral Mixtures

09:45 Glodny J, Kühn A \& Austrheim H:

$\mathrm{Rb} / \mathrm{Sr}$ Record of Fluid-rock Interaction in Eclogites, Bergen Arcs, Norway

10:00 Stein H, Markey R, Sillitoe R \& Perelló J:

Defining the Lifespan of a Giant Porphyry $\mathrm{Cu}$ Deposit: Re-Os Dating at Los Pelambres, Chile

10:15 Bingen B \& Stein H:

Molybdenite Re-Os Dating of Biotite Dehydration Melting: The Rogaland Granulites, S Norway

10:30 Hannah JL, Stein HJ, Zimmerman A, Markey RJ, Sarkar SC \& Pal A:

Late Archean-Early Proterozoic Formation and Reworking of a Porphyry $\mathrm{Cu}(\mathrm{Mo})$ Deposit Recorded in Molybdenite: Re-Os Dating at Malanjkhand, Central India

10:45 Creaser RA \& Selby D:

Re-Os Molybdenite Analysis - Considerations for Accurate and Reproducible Dates

11:00 Selby D \& Creaser RA:

Analytical Considerations for Re-Os Analysis of Organic-rich Sediments

11:15 Seth B, Meisel T, Kleinhanns IC, Kramers JD \& Villa IM:

What Controls Metamorphic De-coupling of Lu-Hf from Sm-Nd?

11:30 Scherer E, Mezger K \& Münker C:

Lu-Hf Ages of High Pressure Metamorphism in the Variscan Fold Belt of Southern Germany

11:45 Barfod GH, Robert F \& Eirik Jens K:

The Closure Temperature of the Lu-Hf Isotopic System in Apatite

Small-scale Processes in Heterogeneous Environments with Relevance to Environmental Biogeochemistry

Convenors: Andre Scheidegger, Ruben Kretzschmar \& Mike Hochella

08:30 Putnis A, Astilleros J, Pina C \& Putnis C:

KEY Heterogeneity of Mineral Surfaces and its Role in Geochemical Surface Reactions

09:00 Schott J, Pokrovsky OS, Spalla O, Devreux F \& Mielczarski JA:

The Mechanism of Altered Layers Formation on Wollastonite Revisited: A Combined Spectroscopic/kinetic Study

09:15 Hellmann R, Penisson J, Hervig R, Thomassin J \& Abrioux M Solution-reprecipitation Responsible for Altered Near-surface Zones during Feldspar Dissolution: Do Leached Layers Really Exist?

09:30 Beig M \& Luttge A:

Albite Dissolution Kinetics: Is it the Pits?

09:45 Arvidson RS \& Luttge A:

Variations in Carbonate Mineral Dissolution Rates: Experimental Uncertainty or Fundamental Property?

10:00 Conrad P \& Luttge A

The Microbe-Mineral Interface: Chemical Reaction Kinetics in Real Time

10:15 Prieto M, Cubillas P \& Fernandez A:

Uptake of $\left(\mathrm{Cd}^{2+}\right)$ aq by Biogenic and Abiogenic Aragonite: A Comparison with Sorption onto Calcite

10:30 Reeder R, Elzinga E \& Rouff A:

INV Coordination of Some Metals Sorbed at the Calcite-water Interface

10:45 Mettler $S$ \& von Gunten $U$ :

Reactivity of $\mathrm{Fe}(\mathrm{II})$ in Presence of Calcite and $\mathrm{Fe} / \mathrm{CaCO}_{3}$ Solid-solution

11:00 Mutter A, Schindler M \& Putnis A:

AFM-examinations of Dissolution and Crystal Growth Processes on the (001) Surface of Schoepite

11:15 Eggleston C, Stack A, Rosso K \& Higgins S:

INV The Structure of Hematite (0001) Surfaces in Water: STM and Resonant Tunneling Calculations of Coexisting $\mathrm{O}$ and $\mathrm{Fe}$ Terminations

11:30 Stack A, Eggleston C \& Higgins S:

Electrochemical STM of Quinones at Hematite (0001) Surfaces: Adsorption of a Biological Electron "shuttle"

11:45 Rosso K \& Zachara J:

INV Theoretical Evaluation of Electron Transfer Kinetics at Fe(III)-Oxide Surfaces with Implications for Microbial Respiration

12:00 Schlegel ML, Nagy KL, Fenter P \& Sturchio NC:

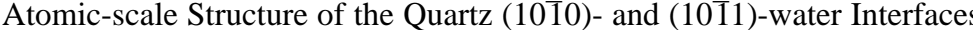




\section{Symposium G09}

Geochemistry and Mineral Physics

\section{क्ष}

Max Schmidt \& Martin Kunz

13:30 Schubel K, Elbert D \& Veblen D:

Crystallographic and Compositional Aspects of C-Domains in Calcium-Rich Dolomite

13:45 Stepanov A, Nadolinny V, Shatsky V \& Kozmenko O:

Study of Local Concentration of Donor Nitrogen in Micro Diamonds from Kokhcetav Massif

14:00 Zhou W, Xie H \& Zhao Z:

Calculation of the Strain, Stress and Elastic Energy for Low-high Quartz Transition up to $1.1 \mathrm{GPa}$

14:15 Sanloup C, Hemley RJ, Mao H \& Jambon A:

High Pressure Investigation of Xe-compounds Relevant for the Earth

14:30 Berry A, O’Neill H, Jayasuriya K \& Campbell S:

A Mössbauer and XANES Spectroscopic Study of Fe Oxidation States in Silicate Glasses

14:45 Cheng L, Fenter P, Bedzyk M \& Sturchio N:

Direct Profiling of Atom Distributions in Mica with X-ray Standing Waves

15:00 Pollok K \& Putnis A:

$\checkmark$

On the Significance of Sharp Interfaces on Nanometer Scale in Oscillatory Zoned Minerals

15:15 Redfern S \& Sartbaeva A:

Transitions and Twin Wall Conduits: Controls on Chemical Transport in Minerals

15:30 Gehring AU, Granwehr J \& Weidler PG:

$\mathrm{Cw}$ and Pulse EPR: A way to Gather Structural Information

15:45 Shikazono N, Ohtani H, Takino A \& Sato H:

Mobility of Rare Earth Elements and Major Elements during Chemical Weathering of Volcanic Soil Profile in Kanto Area, Central Japan
Symposium S02

\section{Stars, Disks and Planetary Growth}

Convenors:

Brigitte Zanda, Conel Alexander, Herbert Palme

13:30 Marcus R:

KEY Mass-independent Isotope Effects

14:00 Lyons J:

Self-shielding of CO in the Solar Nebula

14:15 Alexander $C$ :

How did chondrules/CAIs Acquire their O Anomalies?

14:30 Miller MF, Thiemens MH, Jackson TL, Franchi IA \& Pillinger CT:

Oxygen-17 Anomalies Generated by Thermal Decomposition of Carbonates

14:45 Wasson JT \& Janssen C:

Can Chemical Reactions in the Solar Nebula Produce Anomalous O-isotope Effects in Silicates and Other Solids?

15:00 Alard O, Burton KW, Bland PA \& Russell SS:

Mg-isotopes in Terrestrial and Extraterrestrial Olivines

15:15 Vanhala H:

INV Injection of Radioactivities into the Presolar Cloud

15:30 Dauphas N, Rauscher T, Schatz H, Marty B \& Reisberg L: Technetium-97 and P-radionuclides

15:45 Becker $H \&$ Walker $R$ :

$\mathrm{Ru}$ and Mo Isotopic Constraints on the Scale of Isotopic Homogeneity in Meteorites and their Parent Bodies

16:00 Fehr M, Rehkämper M, Halliday AN \& Porcelli D:

Tellurium Isotopes and the Origin of the Solar System

16:15 Stirling C, Porcelli D \& Halliday A

In Search of Live ${ }^{247} \mathrm{Cm}$ in the Early Solar System

(Symposium S02 Continued in Session 19am on Page 12) 


\section{Symposium S07}

Archean and Proterozoic Oceans, Climates, and Geochemistry

Convenors: Balz Kamber, Dan Schrag, Minik Rosing \& Don Canfield

13:30 Canfield D, Habicht KH, Thamdrup B \& Berg P:

KEY Constraining Sulfate Levels in Archean Oceans

14:00 Lyons T, Kah LC, Gellatly AM \& Frank TD:

Reduced Sulfate Concentrations in the Mesoproterozoic Ocean

14:15 Bekker A, Holland HD, Rumble III D, Wang P \& Coetzee LL:

INV MIF of S, Oölitic Ironstones, Redox Sensitive Elements in Shales, and the Rise of Atmospheric Oxygen

14:30 Runnegar B, Coath C, Lyons J \& McKeegan K:

Mass-independent and Mass-dependant Sulfur Processing Throughout the Archean

14:45 Wing B, Brabson E, Farquhar J, Kaufman AJ, Rumble III D \& Bekker A:

$\delta^{33} \mathrm{~S}, \delta^{34} \mathrm{~S}$ and $\delta^{13} \mathrm{C}$ Constraints on the Paleoproterozoic Atmosphere during the Earliest Huronian Glaciation

15:00 Farquhar J, Wing B, McKeegan K \& Harris J:

INV Insight into Crust-mantle Coupling from Anomalous $\Delta^{33} \mathrm{~S}$ of Sulfide Inclusions in Diamonds

15:15 Jia Y \& Kerrich R:

A ${ }^{15} \mathrm{~N}$ Enriched Archean Crust

15:30 Das Sharma $S$ \& Sreenivas B:

Causal Relationship Among Magmatism, BIFs and Glaciation during the Earliest Paleoproterozoic

15:45 Karhu J:

Paleoproterozoic Positive Carbon Isotope Excursion and Organic Carbon Burial

16:00 Sreenivas B \& Das Sharma $S$ :

Deducing Oxygen Evolution History from Iron and Manganese Retention in Late Archean to Paleoproterozoic Paleosols

16:15 Murakami T, Kasama T \& Utsunomiya S:

Reconstruction of $2.5 \mathrm{Ga}$ Weathering of Pronto Granite
Symposium S11

Room C/A1

Mantle Melting and Magma Transport

Convenors:

Pierre Schiano \& Paul Asimow

13:30 M들 $\underline{\text { Kenzie D }}$ \& Stracke A:

KEY Melt Generation beneath NE Iceland: Melting of a Seamount from the Iapetus Ocean

14:00 Steinthorsson $S$ \& Sigurdsson I:

Glass Inclusions in Early Crystals from Burfell Picrite, Iceland

14:15 Yaxley G, Kamenetsky V, Kamenetsky M \& Francis D:

A Melt Inclusion Study of Baffin Bay Picrites

14:30 Nikogosian I \& Elliott $T$ :

INV Petrology of Parental Melts of Sao Miguel and Pico, Azores Islands: Magmatic Inclusions Study

14:45 Gaetani G, Cherniak D \& Watson B:

INV Diffusive Reequilibration of $\mathrm{CaO}$ in Olivine-Hosted Melt Inclusions

15:00 Shimizu N, Sisson T \& Layne G:

INV Pb Isotopic Variations in Kilauea Magmas: from Pre-shield to Shield Stages

15:15 Phipps Morgan J:

INV Are the Rare Gases within MORB Contained within Melt-inclusion-like Bubbles That Preserve a Record of the Underlying Melting Column?

15:30 Ciuffi S, Rivalenti G, Vannucci R, Zanetti A, Mazzucchelli M \& Cingolani CA: Are the Glasses in Mantle Xenoliths Witness of the Metasomatic Agen Composition?

15:45 Reisberg L, Lorand J \& Bedini R:

The Effects of Melt Percolation on the Os Isotopic Systematics of the Sidamo Peridotites, Ethiopia

16:00 von der Handt A, Snow JE, Hellebrand E, Dick HJ \& Michael P.

Plagioclase Peridotites: Subsolidus Breakdown or Trapped Melt?

(Symposium S11 Continued in Session 19am on Page 14) 


\section{Symposium S12}

\section{Mantle Volatiles: Primordial v Recycled}

\section{Convenors:}

Pete Burnard, Bernard Marty \& Mike Carroll

13:30 Werner C, Chiodini G, Voigt D, Avino R, Caliro S \& Russo M

Monitoring Volcanic Fluxes using Eddy Covariance at Solfatara Volcano, Naples, Italy

13:45 Moretti R \& Ottonello G:

The Solubility and Speciation of Sulfur in Silicate Melts: Development of the Conjugated Toop-Samis-Flood-Grjotheim (CTSFG) Model

14:00 Shimizu A, Sumino H, Nagao K, Notsu K \& Mitropoulos $P$ :

Noble Gas Isotopic Compositions of Gas Samples from the Aegean Arc, Greece

14:15 Hilton D, Fischer T \& Marty B:

KEY Volatile Mass Balance and Recycling at Subduction Zones

14:45 Fischer T, Hilton D, Shaw A, Zimmer M \& Sharp Z

INV A Subduction Zone Barrier for Sediment-Derived Nitrogen

15:00 Mohapatra RK, Harrison D \& Ott U:

Nitrogen in the OIB-mantle

15:15 Aubaud C, Pineau F, Javoy M, Hékinian R \& Cheminée J:

Carbon and Water in Pitcairn and Society Hotspots, French Polynesia

15:30 Cartigny P, Aubaud C, Jendrzejewski N, Harris JW, Pineau F \& Javoy M:

- KEY Carbon in the Earth's Mantle: Neither Primordial nor Recycled but Simply

$$
\text { 'Mantle'-derived }
$$

16:00 Hauri E, Grönvold K, McKenzie D \& Shimizu N

Carbon in the Icelandic Mantle: Constraints from Melt Inclusions

16:15 Klein-BenDavid O, Izraeli ES \& Navon O:

Volatile-rich Brine and Melt in Canadian Diamonds
Symposium S23

Ocean Productivity: Past and Present

Convenors: Martin Frank, Stefano Bernasconi \& Kimitaka Kawamura

13:30 Francois $\mathbf{R}$ :

KEY Paleoproductivity Reconstruction: The On-going Quest for a Quantitative Geochemical Tracer

14:00 Viollier E, Voitel L, Rabouille C, Robin E, Monnin C \& van Beek P:

Kinetic Study of Bio-barite Preservation in Deep-sea Sediments

14:15 Reitz A, Pfeifer K, de Lange GJ \& Klump J:

Direct Versus Indirect Determination of Biogenic Barium as a Proxy for Productivity

14:30 Ostertag-Henning C:

Productivity Markers: Inorganic and Isotopic Proxies Versus Biomarkers

14:45 Brassell S:

Productivity in Cretaceous Oceans: Evidence from Molecular Markers in Organiccarbon Rich Sediments

15:00 Bopp L, Kohfeld K, Le Quéré C \& Aumont O:

Dust Impact on Marine Biota and Atmospheric $\mathrm{CO}_{2}$ in Glacial Periods

15:15 Fleisher MQ, Winckler G, Anderson RF, Stute M \& Schlosser P:

Stable Equatorial Pacific Productivity over the Last $1 \mathrm{Ma}$

15:30 Kawamura K, Seki O, Ikehara M, Ohnishi K, Nakatsuka T \& Narita H:

Reconstruction of Paleoproductivity in the Sea of Okhotsk over the Last $30 \mathrm{Kyrs}$

15:45 Sukumaran NP \& Vaman B

Constrains on the Enhanced Burial of Authigenic Uranium in the Glacial Age Sediments of Arabian Sea 


\section{Symposium S32}

Halogenated Organic Compounds in the Biosphere, Geosphere and Atmosphere

Convenors:

Walter Michaelis \& Heinz F. Schöler

13:30 Gribble GW:

KEY The Natural Production of Organohalogen Compounds

13:45 Butler J:

KEY The Potential Effect of Oceanic Halocarbon Fluxes on Stratospheric Chemistry

14:00 Platt U:

Origin and Role of Reactive Halogen Species in the Troposphere

14:15 Schwandner FM, Gize AP, Seward TM, Hall PA \& Dietrich VJ:

Diffusive Emission of Halocarbons from Volcanic Flanks and Craters

14:30 Schöler H:

KEY Abiotic Formation of Halocarbons during Early Diagenetic Processes

14:45 Silk P \& Macaulay J:

Biosynthesis of Chloroaryl Propane Diols in the Basidiomycete Bjerkandera adusta

15:00 Keppler F, Biester H, Putschew A, Schöler H \& Müller G:

Natural Enrichment of Organic Halogens during Peat Formation

15:15 Christof O, Seifert R \& Michaelis W:

Volatile Halogenated Organic Compounds Distribution in a Coastal Salt Marsh in Northern Germany

15:30 Reddy C, Drenzek N, Sturchio N, Heraty L, Butler A \& Kimblin C:

A Chlorine Isotope Effect for Biochlorination

15:45 Hunkeler D \& Aravena R:

Use of Stable Isotopes to Evaluate the Fate of Chlorinated Hydrocarbons in the Subsurface

16:00 Haderlein SB, Elsner M, Erbs M, Hofstetter T, Pecher $\mathrm{K}$ \& Schwarzenbach RP:

Abiotic Dehalogenation of Aliphatic Contaminants in Heterogeneous $\mathrm{Fe}(\mathrm{II}) / \mathrm{Fe}$ (III) Systems

16:15 Myneni

Probing the Coordination Chemistry of Natural Organo-Cl Compounds using Soft $\mathrm{X}$-rays
Symposium S44

Room A/St

Recent Advances in ICPMS and High-precision Isotope Ratio Mass Spectrometry

Convenors: Mark Rehkämper, Steve Galer \& Dieter Garbe-Schönberg

13:30 Riciputi L, Ingeneri K \& Hedberg $M$ :

Development of a Micro-cavity Ion Source for Enhanced Efficiency in Therma Ionization Mass Spectromety

13:45 Schwieters J, Schwieters JB, Tuttas D, Weyer S, Moll A \& Seedorf R:

Flexible Multiple Ion Counting Detectors for TIMS and ICP Multicollector Mass Spectrometers

14:00 Machado N \& Machado A:

U-Pb Dating of Zircon by Excimer Laser Ablation MC-ICPMS

14:15 Ball L, Sims K, Weyer S \& Schwieters J:

Measurement of ${ }^{232} \mathrm{Th} /{ }^{230} \mathrm{Th}$ in Volcanic Rocks by PIMMS, using the ThermoFinnigan Neptune

14:30 Taylor R, Warneke T, Croudace I, Milton A \& Warwick P:

Plutonium and Uranium Isotope Ratio Measurement by MC-ICP-MS

14:45 Bernal JP, McCulloch M, Mortimer G \& Esat T:

Strategies for the Determination of the Isotopic Composition of Natural Uranium

15:00 Nägler T:

INV Double Spikes: The Gourmets' Choice

15:15 Tanaka T, Senda R, Shibata S, Minami M \& Tanimizu M:

Isotope Diluted Neutron Activation Analysis (ID-NAA) for Quantitative Analysis of PGEs and Re

15:30 Fellner N \& Meisel T:

On-line Separation of PGE

15:45 Meisel T \& Moser J:

Results of Re-Os Round Robin Tests 


\section{Symposium S45}

Room A/Co

Novel Approaches and New Techniques in Dating Minerals, Rocks, and Geological Processes

Convenors:

Igor Villa \& Holly Stein

13:30 Lee J:

Decay-constant Uncertainties of ${ }^{40} \mathrm{~K}$ and the ${ }^{40} \mathrm{Ar} /{ }^{39} \mathrm{Ar}$ Age Equation

13:45 Kelley S, Wartho J \& Steven E:

Experimental Determinations of Ar Diffusion and Solubility in Plagioclase and Leucite

14:00 Hasebe N, Barbarand J, Jarvis K, Carter A \& Hurford T:

Can FT Ages be Derived using LA-ICP-MS?

14:15 Evans JA, Evans J, Zalasiewicz J, Fletcher I, Rasmussen B \& Pearce N:

Dating Diagenetic Monazite in Mudrocks: Constraining the Oil Window?

14:30 Neymark L \& Amelin Y:

Extreme U-Th-Pb Fractionation Among Hydrogenic Fracture-coating Minerals in Felsic Tuffs at Yucca Mountain, Nevada, USA: Implications for Geochronology

14:45 Pashenko S \& Dublyansky Y:

The Role of Radon and Colloids in Distorting U-Pb Age Dates of Geologically Young Minerals Deposited in Open Cavities

15:00 Reiners P \& Spell T:

Intercalibration of Zircon (U-Th)/He and K-feldspar ${ }^{40} \mathrm{Ar} /{ }^{39} \mathrm{Ar}$ Thermochronometry

15:15 Pidgeon RT, Nemchin A, Geisler T \& van Bronswijk W:

Radiation Damage in $>4$ Ga Zircons from the Jack Hills, Western Australia

15:30 Cocherie A, Rossi P, Fanning CM \& Deloule E:

Accretion and Splitting within the Permian Pangea Recorded by Episodic Metamorphic Zircon Growth

15:45 Kagan E, Bar-Matthews M, Ayalon A \& Agnon A:

A Wiggle-matching Technique Applied to the Dating of Damaged Cave Deposits and Compilation of a Long- Term Paleoseismic Record, Soreq Cave, Israel
Symposium S48

Room B/Ja

Small-scale Processes in Heterogeneous Environments with Relevance to Environmental Biogeochemistry

Convenors: Andre Scheidegger, Ruben Kretzschmar \& Mike Hochella

13:30 Brown G \& Parks GA:

INV Metal Ion Sorption Processes in the Marine Environment - An Old Subject Revisited

13:45 Scheidegger AM, Grolimund D \& Chesseman C

A Microspectroscopic Study on the Influence of the Inherent Heterogeneity of Waste Repository Materials on Contaminant Uptake

14:00 Vantelon D, Lanzirotti A, Aeschlimann B, Guenther D, Scheinost A \& Kretzschmar R:

Micro-scale Pb Distribution and Oxidation in a Shooting Range Soil

14:15 Scheinost AC, Kretzschmar R, Newville M \& Sutton S:

Spatial and Temporal Variation of Zn Species in the Rhizosphere of a Contaminated Soil

14:30 Morin G, Juillot F, Allard T, Casiot C, Elbaz-Poulichet F \& Calas G:

INV XAS Monitoring of Arsenic (Bio-)Oxidation and Immobilisation in Soils and Acid Mine Drainage

14:45 McKinley JP, Zachara JM, Heald SM \& Fredrickson JK:

The Reductive Immobilization of Pertechnetate by Bioreduced Sediments

15:00 Thieme J:

INV The Study of Geochemical Processes with X-ray Spectromicroscopy

15:15 Farges F:

INV New Concepts in XAFS Analysis

15:30 Furrer G, Casey W \& Phillips B:

INV The Continuous Growth of Aqueous Aluminum Nanoclusters

15:45 Banerjee D, Furrer G, Hany R, Rentsch D \& Wehrli B:

Chemical Reactivity of Aqueous Aluminum Nanoclusters

16:00 Favre F, Ernstsen V, Tessier D \& Boivin P:

Short Scale Changes in Soil Properties due to Structural Iron Reduction

16:15 Tadanier CJ, Luxton TP \& Eick MJ:

INV Competitive Adsorption of Oxyanions

(Symposium S48 Continued in Session 19am on Page 17) 


\section{Symposium G07}

\section{Geochemistry of Pollution}

\section{Convenors:}

\section{Malcolm McCulloch \& Björn Öhlander}

10:15 Kim C, Shaw S, Lowry GV, Rytuba JJ \& Brown, Jr. GE:

Mercury Speciation in Bulk and Colloidal Mine Wastes: Origins, Influences, and Implications

10:30 Ohlander B \& Corrége $O$ :

Evolution of the Groundwater Geochemistry in Sulphide-rich Mine Tailings Remediated by Pplying Soil Cover, Kristineberg, Northern Sweden

10:45 Langmuir D, Mahoney J, Slaughter M \& Rowson J:

Controlling Arsenic Concentrations in Buried Uranium Mill Tailings

11:00 Huisman DJ, Vriend S, Gunnink J \& Kloosterman F:

Arsenic in the Netherlands: Processes, Spatial Distribution and Risk

11:15 Liao L \& Fraser DG:

The Adsorption of As onto Hydroxy-Fe-Montmorillonite Complexes

11:30 Hug SJ, Leupin O \& Voegelin A:

Iron Catalysed Thermal and Photochemical Oxidation of Arsenic(III)

11:45 Tournassat C \& Charlet L:

The Sorption of Ferrous Iron onto Clay Minerals: Could Aqueous Fe(II) Outcompete with Radionuclides for Immobilization?

(Symposium G07 Continued in Session 19pm on Page 18)

\section{Symposium S02}

\section{Stars, Disks and Planetary Growth}

Convenors:

Brigitte Zanda, Conel Alexander, Herbert Palme

\& Ed Young

08:30 Guyot F, Leroux H, Carrez P, Cordier P \& Lemelle L:

Chemical Fractionations Induced by Irradiation in Early Solar Materials: Results from Laboratory Experiments

08:45 Chaussidon M, Robert F \& McKeegan KD:

INV Extinct ${ }^{7} \mathrm{Be}$ and ${ }^{10} \mathrm{Be}$ in Refractory Inclusions from the Allende and Efremovka Chondrites

09:00 Leya I, Wieler R \& Halliday AN:

Nucleosynthesis by Spallation Reactions in the Early Solar System

09:15 Gounelle M \& Russell S:

INV On Early Solar System Chronology

09:30 Carlson R:

$K E Y \quad$ A Quick Trip from Dust to Planets

10:00 Ash R, Russell S, Gounelle M, Young E \& Belshaw N:

INV Was ${ }^{26} \mathrm{Al}$ a Chronometer or Heat Source in the Early Solar System?

10:15 Kita N, Mostefaoui S, Tachibana S \& Nagahara H:

The ${ }^{26} \mathrm{Al}$ Ages of Chondrules as the Chemical Records of the Active Proto-planetary Disk

10:30 Amelin Y, Rotenberg E \& Krot A:

$\mathrm{Pb}$ Isotopic Dating of Chondrules

10:45 Lee D, Halliday AN \& Zanda B:

${ }^{182} \mathrm{Hf}-{ }^{182} \mathrm{~W}$ Chronometry for Renazzo and Bencubbinites

11:00 Campbell AJ, Humavun $M$ \& Zanda B

INV Partial Condensation of Volatile Elements in Renazzo Chondrules

11:15 Zanda B, Humayun M, Hewins RH, Bourot-Denise M \& Campbell AJ:

The Relationship between Volatile Element Patterns and Chondrule Textures in CRs and OCs

11:30 Righter K, Campbell AJ \& Humayun M:

Diffusion in Metal: Application to Zoned Metal Grains in Chondrites

11:45 Nagahara H \& Ozawa K:

Chemical Diversity of Chondrule Melt and its Origin

12:00 Russell S, Gounelle M, Jeffries T \& Alard O:

INV REEs in Al-rich Chondrules: Clues to their Origin 


\section{Symposium S06}

The Pre-RNA World and the Origin of Life

\section{Convenors:}

\section{Antonio Lazcano, Francis Westall \& Jeffrey Bada}

11:00 Lancet D, Kafri R \& Shenkav B

KEY Compositional Genomes: Pre-RNA Information Transfer in Mutually Catalytic Assemblies

11:30 Parmon V \& Snytnikov V:

Origin of Life from the View Point of Chemical Catalysis

11:45 Hansson TK, Cohn C, Larsson H, Sowerby S \& Holm N: Fate of Prebiotic Adenine

12:00 Galimov E:

ATP is a key Molecule of Prebiotic Evolution

12:15 Harrison M, Mojzsis SJ, Pidgeon RT, Ireland TR, Bennett V \& Honda M: A Mission to Really Early Earth: When Did the Earth Become Suitable for Habitation?
Symposium S07

Room C/S2

Archean and Proterozoic Oceans, Climates, and Geochemistry

\section{Convenors: Balz Kamber, Dan Schrag, Minik Rosing \& Don Canfield}

08:30 Zheng Y, Gong B, Li L \& Feng W:

INV A Large Scale of Meteoric-hydrothermal Alteration at Neoproterozoic in the Yangtze Craton of China

08:45 Mazumdar A, Kawabe I, Tanaka K \& Takahashi T:

REE Geochemistry of Late Proterozoic Shallow Marine Carbonate, India

09:00 Godderis Y, Nedelec A, Donnadieu Y, Francois L, Grard A \& Dupre B: Snowball Earth and Basaltic Traps

09:15 Pierson-Wickmann A, Kyser TK, James N \& Narbonne G:

Neoproterozoic Glaciations in the Windermere Supergroup, Canada

09:30 Hoffman PF, Van Dusen A, Halverson GP, Saenz J, Kaufman AJ \& Schrag DP Significance of Sea-floor Barite Cements in Marinoan-age Post-glacial Cap Carbonates

09:45 Workman RK, Grotzinger JP \& Hart SR:

Constraints on Neoproterozoic Ocean Chemistry from $\delta^{13} \mathrm{C}$ and $\delta^{11} \mathrm{~B}$ Analyses from the Witvlei and Nama Groups, Namibia

10:00 Halverson GP, Schrag D \& Hoffman P:

Detailed Geochemical Data Before and After Snowball (Ghaub) Glaciation in Namibia

10:15 Kennedy M \& Christie-Blick N:

Isotopic and Physical Stratigraphic Constraints of Neoproterozoic Cap Carbonate; Implications for Post Glacial Oceanographic Models and Weathering Rates

10:30 Higgins J \& Schrag DP:

Modeling the Carbon Cycle in the Aftermath of a Snowball Earth

10:45 Kirschvink J:

Precambrian/Cambrian Carbon Cycles and True Polar Wander: A Methane Connection? 


\section{Symposium S11}

\section{Mantle Melting and Magma Transport}

\section{Convenors:}

Pierre Schiano \& Paul Asimow

\section{8:30 Sims K, Mattielli N, Elliott T, Kelemen P, DePaolo D \& Mertz D:}

KEY $\quad{ }^{238} \mathrm{U}$ and ${ }^{230} \mathrm{Th}$ Excesses in Kolbeinsey Ridge Basalts

09:00 Saal AE, Van Orman JA, Hauri EH, Langmuir CH \& Perfit MR:

INV An Alternative Hypothesis for the Origin of the High ${ }^{226} \mathrm{Ra}$ Excess in Mid-ocean Ridge Basalts

09:15 Feineman MD, DePaolo DJ \& Ryerson FJ:

Steady-state ${ }^{226} \mathrm{Ra} /{ }^{230} \mathrm{Th}$ Disequilibrium in Hydrous Mantle Minerals

09:30 Sims K, Kelemen P \& Jull M:

INV Consequences of Diffuse and Channelled Porous Melt Migration on Uranium Series Disequilibria

09:45 Muntener O, Desmurs L, Pettke T \& Schaltegger U:

Melting and Melt/rock Reaction in Extending Mantle Lithosphere: Trace Element and Isotopic Constraints from Passive Margin Peridotites

10:00 Godard M, Gerbert-Gaillard L \& Bodinier J

INV Melt Freezing at the Lithosphere-asthenosphere Interface: Geochemical Evidence from the Oman Peridotites

10:15 Asimow PD:

INV Melt Migration vs. Isentropic Decompression Melting, More or Less

10:30 Spiegelman $M$ \& Kelemen P:

INV Highway to Hell: Geochemical Consequences of Channelized Melt Transport

10:45 Hellebrand E, Snow JE \& Hofmann AW:

Deep Melting Underneath the Ultraslow Lena Spreading Center

11:00 Tirone $M$ \& Ganguly J:

Thermodynamic Control on Thermo-Fluid Dynamic Mantle Flow Model

11:15 Kelemen P:

INV Melt Transport in the Mantle beneath Oceanic Spreading Ridges

11:30 Peslier AH, Brandon AD, Francis D \& Ludden J:

Melt-rock Reaction in Canadian Cordillera Mantle Xenoliths

11:45 Malitch K:

Constraints on Melting and Osmium Isotopic Sources in the Ophiolitic Upper Mantle: Evidence from Ru-Os Sulfides and Os-Ir-Ru Alloys

(Symposium S11 Continued in Session 19pm on Page 19)

\section{Symposium S14}

Characterising Slab, Mantle and Crustal Contributions to

\section{Ares}

\section{Convenors:}

\section{Mike Dungan \& Jon Davidson}

08:30 Hirschmann M \& Thomas R:

KEY A Flux-ingrowth Model for Melt Generation in Mantle Wedges

09:00 Langmuir CH \& Spiegelman M:

INV Influence of Subduction Parameters on Wedge Melting

09:15 Kelemen P, Parmentier M, Rilling J, Mehl L \& Hacker B:

INV Thermal Convection in the Mantle Wedge

09:30 Dosseto A \& Bourdon B:

Models for Genesis of Kamchatka Arc Magmas: New Insights from U-series

09:45 Sun W, Bennett V, Eggins S, Arculus R, Kamenetsky V \& Falloon T:

Rhenium Systematics in Submarine MORB, Arc and Back-Arc Basin Glasses by Laser Ablation ICP-MS

10:00 Leeman W \& Tonarini S:

INV Geochemical Tracers of Slab Contributions to Arc Magmas: The use of Boron

10:15 Castillo PR:

Is Slab-derived Melt Present beneath the Southern Philippine Arcs?

10:30 Cervantes $P$ \& Wallace $P$ :

$\mathrm{H}_{2} \mathrm{O}, \mathrm{S}$ and $\mathrm{Cl}$ in Subduction Zone Magmas: Insights from Melt Inclusions in High$\mathrm{Mg}$ Basalts from Central Mexico

10:45 Shaw A, Hilton D, Fischer T \& Walker J:

Unravelling the C Systematics of the Central American Volcanic Output

11:00 Ishizuka O, Taylor R, Milton A \& Nesbitt R:

Fluid-mantle Interaction in an Intra-oceanic Arc: Constraints from High-precision $\mathrm{Pb}$ Isotopes

11:15 Pearce JA, Kempton PD \& Gill JB:

INV Behaviour of High Field Strength Elements in Subduction Systems

11:30 Downes H, Thirlwall M \& Trayhorn S:

Mantle Source Enrichment beneath Sardinia (Italy): Evidence from Oxygen Isotope Analyses

11:45 Klemme S, Blundy JD \& Wood BJ:

Some Experimental Constraints on Major and Trace Element Partitioning during Partial Melting of Eclogite

(Symposium S14 Continued in Session 19pm on Page 20) 


\section{Symposium S20}

Linking Geochronology with Petrology and Textures

\section{Convenors:}

\section{Wolfgang Müller \& Derek Vance}

08:30 Foster G, Parrish R \& Horstwood M:

$\begin{array}{lll} & I N V & \text { Metamorphic Monazite and the Generation of P-T-t Paths } \\ \text { 08:45 Rubatto D: }\end{array}$

INV The Link between U-Pb Ages of Accessory Minerals and Metamorphic Conditions

09:00 Möller A, O'Brien PJ, Hellebrand E, Mocek B \& Kröner A:

Melt-host Rock Interaction and Zircon Growth during High Grade Metamorphism

09:15 Spear FS, Cheney JT, Pyle JM \& Storm LC:

KEY Monazite: Another Rosetta Stone?

09:45 Anczkiewicz R, Thirlwall MF \& Platt JP:

INV Influence of Inclusions and Leaching Techniques on Sm-Nd and Lu-Hf Garnet Chronology

10:00 Stowell H \& Tinkham D:

Integration of Phase Equilibria Modelling and Garnet Sm-Nd Geochronology for Construction of P-T-t Paths: Examples from the Cordilleran Coast Plutonic Complex, USA

10:30 Magloughlin J \& Koenig A:

INV REE Systematics in Metamorphic Garnet: Insights from LA-ICP-MS

\section{Reng Y, Gong B, Yang J \& Jahn B:}

Disequilibrium Sm-Nd and O Isotope Systems in Garnet Peridotite during UHP Metamorphism

11:00 Moens L, Vanhaecke F \& Balcaen L:

INV Reaction Cell ICP-MS to Facilitate Rb-Sr Age Determination

11:15 Camacho A, Lee J \& Hensen B:

Thermal Disequilibrium in the Lower Crust: Evidence from the Bergen Arcs, Norway

11:30 Cosca M, Giorgis D, Kramar N, Mulch A \& Putlitz B:

Smaller Means More: UV Laser Ablation ${ }^{40} \mathrm{Ar} /{ }^{39} \mathrm{Ar}$ Methods Require Detailed Sample Characterization

11:45 Mulch A, Cosca MA \& Fiebig J:

In situ ${ }^{40} \mathrm{Ar} /{ }^{39} \mathrm{Ar}$ UV Laser Dating of Mylonitic Mica Fish: Cooling or Crystallisation Ages?

(Symposium S20 Continued in Session 19pm on Page 20)

\section{Symposium S24}

\section{Ocean Paleotemperatures}

Convenors:

David Lea, Ros Rickaby \& Thomas Nägler

08:30 Sachs J \& Anderson R:

KEY Surface Temperatures from Alkenones in Late Quaternary Marine Sediments

09:00 Kienast M, Hanebuth T, Pelejero C \& Steinke S:

INV Synchroneity of the Bølling Warming in the South China Sea (SCS) and Greenland: Implications for the Regional Diversity of Deglacial Warming, SCS Reservoir Ages, and the Timing of MWP 1a

09:15 Mulitza S, Rühlemann C, Arz H, Paul A \& Wefer G

INV Tropical Atlantic Warming during Thermohaline Circulation Slowdown

09:30 Herbert T:

INV Glacial-Interglacial Tropical Sea Surface Temperature Changes Deduced from the Alkenone Paleothermometer

09:45 Mangelsdorf K, Güntner U \& Rullkötter J:

Mid-chain Diols and Keto-ols as Potential Paleoenvironmental Tracers for the California Continental Margin during the Late Quaternary

10:00 Marchal O, Cacho I, Stocker T, Grimalt J, Calvo E \& Martrat B

INV Apparent Long-term Cooling of the Sea Surface in the Northeast Atlantic and Mediterranean during the Holocene

10:15 Deyhle A, Macdougall D, MacIsaac C \& Paytan A

INV Temperature Dependence of Ca Isotope Fractionation in Marine Carbonates

10:30 Eisenhauer A, Gussone N, Dietzel M, Heuser A, Bock B \& Böhm F:

INV Kinetic Effects on Calcium Isotope $\left(\delta^{44} \mathrm{Ca}\right)$ Fractionation in Calcium Carbonate

10:45 Hippler D, Gussonne N, Darling K, Eisenhauer A \& Nägler T:

$\delta^{44} \mathrm{Ca}$ in N. Pachy (left): A New SST-proxy in Polar Regions

11:00 Immenhauser A, Nägler T, Steuber T \& Hippler D:

Seasonal Variations in a "greenhouse" Earth: Cretaceous Coastal Sea-surface Temperatures Inferred from ${ }^{18} \mathrm{O} /{ }^{16} \mathrm{O}, \mathrm{Mg} / \mathrm{Ca}$ and ${ }^{44} \mathrm{Ca} /{ }^{40} \mathrm{Ca}$ Ratios

11:15 Schmitt A, Stille P \& Vennemann T:

Variations of the ${ }^{40} \mathrm{Ca} /{ }^{44} \mathrm{Ca}$ Ratio in Seawater during the Past 24 Million Years: Evidence from $\delta^{40} \mathrm{Ca}$ and $\delta^{18} \mathrm{O}$ Values of Miocene Phosphorites

11:30 Böhm F, Eisenhauer A, Gussone N, Heuser A, Haase-Schramm A \& Dietzel M Fractionation of ${ }^{44} \mathrm{Ca} /{ }^{40} \mathrm{Ca}$ between Aragonite and Calcite

11:45 Marriott C, Belshaw N \& Henderson G:

Lithium and Calcium Isotope Fractionation in Inorganically Precipitated Calcite: Assessing their Potential as a Paleothermometer

12:00 Elderfield H:

$M E D$ Foraminiferal $\mathrm{Mg} / \mathrm{Ca}$ Paleothermometry: Expected Advances and Unexpected Consequences

(Symposium S24 Continued in Session 19pm on Page 21) 


\section{Symposium S30}

Biogeochemical Processes in Lakes

Room B/Pi

\section{Convenors: Bernhard Wehrli, Liba Granina \& Jean François Gaillard}

08:30 Eisenreich S, Dachs J, Baker J \& Jeremiason J:

KEY Organic Contaminants in Lakes: Atmospheric Exchange and Linkage to the Trophic Status of Lakes

09:00 Hesslein R, Guss DM, Schindler EU \& Kasian SEM:

INV A Carbon Budget for Canadian Shield Lakes

09:15 Helie J, Hillaire-Marcel C \& Varfalvy L:

Isotopic Insights into Carbon Metabolism in a Boreal Forest Hydroelectric Reservoir of the James Bay Area (Canada)

09:30 Ito E, Bacon S, Smith A \& Palmer D:

INV Geochemistry of Ostracode Calcite: Empirical Calibration of 3 Species from Page Pond, Ohio, U.S.A

09:45 Vreca P \& Muri G:

Stable Isotope Ratios of Sedimentary Organic Matter as Indicators of Mountain Lake Trophic State Changes

10:00 Gächter R \& Müller B:

INV No Effect of Hypolimnetic Aeration on the P Cycling of Lake Sempach a Re-evaluation of a Well-accepted Concept

ڤึ 10:15 Märki M, Müller B, Dinkel C \& Wehrli B:

Nitrogen Turnover in Lake Sediments - Seen with Ion-Selective Electrodes

10:30 Dittrich M, Reichert P \& Wehrli B:

Diagenetic Modelling of Anaerobic Lake Sediments

10:45 Reichert P, Dittrich M \& Wehrli B:

Identifiability Analysis of a Diagenetic Model

11:00 Brennwald MS, Kipfer R, Peeters F, Hofer M, Aeschbach W \& Imboden D: Noble Gases Dissolved in Porewater of Lacustrine Sediments

11:15 Peiffer S, Regenspurg S \& Kuesel K:

INV Geochemical Constraints for the Remediation of Acidic Mining Lakes

11:30 Ptacek CJ, Moncur MC, Blowes DW, Jambor JL \& Mayer UK:

Relation between Redox Processes in Groundwater and an Adjacent Lake at an Abandoned Mine Site

11:45 Blodau C:

The Influence of Groundwater Inflow on Neutralization Rates in Acidic Mine Lakes

\section{Symposium S47}

Microanalysis Mass-spectrometric Techniques

\section{Room A/St}

\section{Convenors:}

D. Günther \& N. Shimizu

08:30 Jackson SE \& Gunther D:

KEY Studies of the Source of Laser-induced Isotopic Bias in LA-MC-ICP-MS

09:00 Hirata T:

INV Chemically Assisted-Laser Ablation-ICP-Mass Spectrometry

09:15 Horn I \& Günther D:

INV Transport Efficiency and Particle Size Distribution of Laser Induced Aerosols

09:30 Iizuka T \& Hirata T:

Simultaneous Determinations of U-Pb Age and REE Abundances for Zircons using Laser Ablation-ICPMS

09:45 Tiepolo M, Palenzona M \& Vannucci $R$ :

In situ U-Pb Dating of Zircon by Means of Single-collector Sector-field LA-ICP MS

10:00 Griffin WL, O'Reilly SY, Pearson NJ \& Graham S:

In situ Re-Os Dating of Sulfides in Kaapvaal Xenoliths

10:15 Stadermann FJ:

$K E Y$ Isotopic and Elemental Studies at a $50 \mathrm{~nm}$ Scale with the NanoSIMS

10:45 Morishita Y \& Satoh H:

Silicon Isotope Zonings in Synthesized Silicon Crystals

11:00 Pellin M, Davis A, Veryovkin I, Calaway W \& Savina M:

Upgrades to CHARISMA: Approaching the Atom-counting Limit

11:15 Williams I:

INV How Reliable are the U-Pb Ages Measured on Inherited Zircon?

11:30 Lavne G \& Cohen A:

INV Advantages of Secondary Ion Mass Spectrometry for Trace Element Studies of Marine Biomineralization

11:45 Pettke T, Webster J, Halter W, Heinrich C, Aigner-Torres M \& De Vivo B:

INV Advantages and Limitations of Quantifying Melt Inclusion Chemistry by LAICPMS, EMP and SIMS

12:00 Svojtka M \& Kosler J:

Fission-track Dating of Zircon by Laser Ablation ICPMS

(Symposium S30 Continued in Session 19pm on Page 22) 


\section{Symposium S48}

Small-scale Processes in Heterogeneous Environments with Relevance to Environmental Biogeochemistry

Convenors: Andre Scheidegger, Ruben Kretzschmar \& Mike Hochella

08:30 Fendorf S, Hansel C, Benner S, Nico P, Reville K \& Bostick B

KEY Biogenic Evolution of Microscale Heterogeneity: Impact on Contaminant Dynamics

09:00 Behrends T \& Van Cappellen P:

Abiotic vs. Microbial Reduction of Uranium (VI)

09:15 Benning LG, Yee N, Phoenix V \& Konhauser K:

The in situ Molecular Characterisation of a Biomineralization Process: A Synchrotron Infrared Study

09:30 Cooper C, Neal A \& Picardal F:

Effect of Sediment Mineralogy on Microbiologically Induced (DMRB) Changes in Divalent Metal Speciation

09:45 Wolthers M, van der Weijden CH, Rickard D, Van Cappellen P \& Charlet L: Arsenic Association with Iron Sulphides, Adsorption and Incorporation

10:00 Bostick B, Doyle C, Fendorf S, Kendelewicz T, Bargar J \& Brown GE: Role of Arsenic in Pyrite Oxidation
Symposium S49

$\operatorname{Room~A/Fm~}$

\section{The Geochemistry of Biogenic Minerals}

Convenors:

\section{Anne Cohen, Patricia Dove, Nobuchimi Shimizu}

\& Steve Weiner

08:30 Weiner S \& Addadi L:

KEY Calcium Carbonate Formation in Biology: The Involvement of an Amorphous Calcium Carbonate Precursor Phase

09:00 Paquette J, Yung-Ching C, Mucci A \& Vali H:

INV Abiotic Calcites: Crystal Morphology, Zoning and Microstructure

09:15 Henriksen K, Stipp S, Young J \& Bown P:

Calcite Biomineralization in Coccoliths: Evidence from Atomic Force Microscopy (AFM)

09:30 Visscher PT, Reid RP, McKenzie JA \& Vasconcelos C:

Geomicrobial Mechanisms of Carbonate Precipitation: Novel Insights from Laminated Structures

09:45 Finch A, Allison N, Sutton S \& Newville M:

Characterisation of $\mathrm{Sr}$ in Coral Aragonite by EXAFS

10:00 Erez J, Bentov S, Brownlee C, Raz M \& Rinkevich B:

KEY Biomineralization Mechanisms in Foraminifera and Corals and their Paleoceanographic Implications

10:30 Cuif JP \& Dauphin Y:

Proteoglycan Diversity and Aragonite Crystallization Patterns in Coral Skeletons: A Reinterpetation of Isotopic "Biological Mismatches"

10:45 Kobayashi A \& Taguchi T:

Biological Control of Magnetite Crystal Formation in the Magnetotactic Bacteria Hints Concerning the Possible Evidence from ALH84001 for Life on Mars

11:00 Watson B

KEY Interfacial Phenomena Possibly Affecting Trace-Element and Isotope Ratios in Biogenic Carbonates

11:30 Stoll H \& Ziveri P.

INV Controls over the Chemistry of Coccolith Calcite

11:45 Rickaby R, Schrag D \& Morel F:

INV Coccolith Chemistry Considered

(Symposium S49 Continued in Session 19pm on Page 22) 


\section{Symposium G07}

\section{Geochemistry of Pollution}

\section{Convenors:}

\section{Malcolm McCulloch \& Björn Öhlander}

13:30 McCulloch M, Fallon S \& Wyndham T:

Geochemical Tracing of Human Impacts on Coral Reefs

13:45 Xiao H \& Liu C:

Isotopic Compositions of Sulphur and Nitrogen in Rains of Guiyang, China

14:00 Juillot F, Morin G, Ponthieu M, Benedetti M, Trainor T \& Kinniburgh D:

Zinc Trapping in Layered Double Hydroxydes (LDHs) and Phyllosilicates in Contaminated Soils from Western Europe

14:15 Kretzschmar R, Voegelin A, Pfister S, Barmettler K \& Scheinost A:

Formation and Dissolution of Zn-precipitates during Reactive Transport in a Circum-neutral Soil

14:30 Spijker J, Vriend S \& van Gaans P:

Geochemical Mapping of Soils for Natural Background and Diffuse Contamination Patterns

14:45 Sammartino I, Amorosi A, Dinelli E \& Lucchini F:

Subsurface Sediments as a Tool to Estimate Regional Background: Validation and Application in the Eastern Po Plain

15:00 Grosbois C, Meybeck M \& Horowitz A:

Spatial and Temporal Trends for Sediment-associated Metal Contamination in the Seine River Basin (France)

15:15 Givelet N \& Shotyk W:

Solubility of Iron(III) and Aluminum Phosphates in Aqueous Solutions

15:30 Zhu J, Liang X, Zheng B \& Li S:

Occurrence of Native Selenium in Yutangba of China

15:45 Dangic J \& Dangic A:

Geochemical Model of Lead in Supergenic Systems: Mobility, Impacts of Cerusite and Fe-oxyhydroxides

\section{Symposium S02}

\section{Stars, Disks and Planetary Growth}

Convenors:

Brigitte Zanda, Conel Alexander, Herbe

\section{\& Ed Young}

13:45 Benz W:

KEY The Formation of Planets: Problems and Prospects

14:15 Quitté G \& Halliday AN:

Nickel Isotopes in Meteorites: Constraints on the Early Solar System

14:30 Ebel DS \& Alexander CMO:

INV Origin of Enstatite Chondrites and Implications for the Inner Planets

14:45 Wombacher F, Rehkämper M, Mezger K, Münker C \& Bischoff A:

Stable Isotope Compositions of Cadmium in Stony Meteorites

15:00 Marti K, Kim Y, Min K, Renne P \& Farley K:

INV Acapulco Recorded an Early Asteroidal Heat Pulse

15:15 El Goresy A, Zinner E, Pellas P \& Caillet C:

INV Various Graphite Morphologies with a Diversity of C-and $\mathrm{N}$-isotopic Signatures in the Highly Equilibrated Acapulco Meteorite

15:30 Bell KR:

KEY The Early Evolution of the Solar Nebula with Implications for the Formation of Primitive Material 


\section{Symposium S05 \\ Source of Organic Compounds on the Early Earth and Other Solar System Bodies}

Convenors:

Gerda Horneck \& André Brack

13:30 Maurette M:

KEY Cosmic Origin of Volatile Species on the Early Earth and Mars

14:00 Bar-Nun A \& Owen T:

Cometary Delivery of Water, Noble Gases and Organics to Earth

14:15 Levasseur-Regourd A:

Physical Properties of Some Early Earth Impactors: Cometary Dust Particles and Cometary Nuclei

14:30 Flynn G, Keller L, Wirick S \& Jacobsen C:

INV The Origin of Solar System Organic Matter: Evidence from IDPs

14:45 Watson JS, Sephton M, Love G, Verchovsky S, Snape C \& Gilmour I:

Hydropyrolysis of the Organic Macromolecular Material in the Murchison Meteorite

15:00 Glavin DP, Matrajt G \& Bada JL:

INV A Search for Extraterrestrial Amino Acids in Antarctic Micrometeorites

15:15 Ione K:

Modelling of Catalytic Abiogenous Synthesis of the Hydrocarbons in the Earth's Crust

15:30 Matsuno K:

INV Evolution of a Prebiotic Ecosystem of Amino Acids in Hydrothermal Environments

15:45 Horneck G

Meteorites as Potential Source of Microorganisms on Early Earth and Mars

16:00 Meierhenrich U, Munoz Caro G, Schutte W, Barbier B, Arcones Segovia A \& Brack A:

Amino Acids from Ultraviolet Irradiation of Interstellar Ice Analogues
Symposium S11

Room C/A1

Mantle Melting and Magma Transport

Convenors:

Pierre Schiano \& Paul Asimow

13:30 Kohlstedt DL \& Holzman BK:

KEY Shearing Melt out of the Mantle

14:00 Toomey DR \& Hammond WC:

INV Seismic Anisotropy and Heterogeneity beneath the MELT Region

14:15 Jackson I, Faul U, Fitz Gerald J \& Tan B.

INV Systematics in the Seismic Wave Attenuation of Partially Molten Olivine Aggregates

14:30 Lensky NG, Niebo RW, Holloway JR, Lyakhovsky V \& Navon O:

Bubble Nucleation as Trigger for Dike Initiation in the Mantle

14:45 Blundy $\mathrm{J}$, McDade $P$ \& Wood B:

INV EPSL Frontiers Lecture: Chemical Evolution of Olivine-hosted Melt Inclusions in MORB

15:00 Lundstrom C, Chaussidon M, Kelemen P \& Hsui A:

INV Li Isotope Profiles in Dunite to Lherzolite Transects within the Trinity Ophiolite

15:15 Griesshaber E, Niedermann S, Schulte U, Möller P \& Dulski P. Geochemical Characteristics of the Mantle Plume at the Eifel

15:30 Barth MG, Mason PR, Davies GR \& Drury MR:

Geochemistry of the Othris Ophiolite, Greece: Towards a Solution of the "Ophiolite Conundrum"

15:45 Ramos FC:

Mantle Sources Generating Recent Volcanism along the Perimeter of the Colorado Plateau

16:00 Raffone N, Zanetti A, Chazot G, Pin C \& Vannucci R:

The Composition of Mid Atlas Lithospheric Mantle 


\section{Symposium S14}

Characterising Slab, Mantle and Crustal Contributions to Arcs

\section{Convenors:}

\section{Mike Dungan \& Jon Davidson}

13:30 Grove T:

$K E Y$ Sorting out Contributions from Slab and Mantle Wedge in Arc Magmas

14:00 Dungan M, Jon D, Frederick F \& Laurie C:

Compositional Diversity in Mafic Andean Arc Magmas Generated by Assimilation of Amphibole- and Phlogopite-bearing Cumulates

14:15 Foden J, Elburg M \& Turner S:

INV Sangeang Api: Upper Plate Magma Chamber Processes and the Origin of Alkaline Arc Lavas

14:30 Schiano P.

The Nature of Melt Inclusions Inside Minerals in Ultramafic Cumulates from Island Arcs: Implications for the Origin of high-Al Basalts

14:45 Chesley J, Ruiz J \& Righter K:

INV Decoupling of the Os Isotopic System during Crust-mantle Interaction in Continental Arc Volcanic Systems

15:00 Munday D, Thirlwall M, Smith T \& Davidson J:

INV Hf and $\mathrm{Nd}$ Isotope Decoupling in the Lesser Antilles Island Arc

ㅇ 15:15 Tonarini S, Civetta L, D'Antonio M, D'Orazio M, Innocenti F \& Leeman W: Boron Isotope Systematics in South Italy Volcanoes

15:30 Elburg M, Foden J, van Bergen M \& Zulkarnain I:

Geochemical Response to Arc-continent Collision on Alor, Sunda-Banda Arc, Indonesia

15:45 Herrin JS, Nikogosian IK, Van Bergen MJ \& Mason PR:

Multiple Sources for Ultrapotassic Arc Magmas from Batu Tara Volcano, Indonesia
Symposium S20

Room A/Co

Linking Geochronology with Petrology and Textures

Convenors:

Wolfgang Müller \& Derek Vance

13:30 Ganguly J \& Tirone M:

INV Closure Temperature and Age of Minerals

13:45 Jenkin G, Townley H \& Parrish R:

INV Sr-isotope Diffusion Profiles from Alpine Marbles: What do They Mean?

14:00 Baxter E \& DePaolo D:

INV Can Metamorphic Reactions Proceed Faster Than Strain?

14:15 Kramar N, Cosca MA \& Buffat P:

Stacking Fault-enhanced Argon Diffusion in Naturally Deformed Muscovite

14:30 Wartho JJ \& Kelley S:

Ar-Ar Ages in Xenolith Phlogopites - Information on the Earth's Lithospheric Mantle and Kimberlites

15:00 Romer RL \& Rötzler J:

Effect of Metamorphic Reaction History on Isotopic Dating of Minerals

15:15 Udin D, Travin A, Vladimirov V, Prostyakov K \& Barabash N:

Age Spectra of Biotite as Indicator of Deformation Rate: Evidence from

15:30 Jung $S$ :

Microchemical, Structural, Step-heating and Laser ${ }^{40} \mathrm{Ar}{ }^{39} \mathrm{Ar}$ Analyses

U-Pb Zircon, Sphene and Apatite Ages from Shear Zone-hosted Syenites: Implications on $\mathrm{Pb}$ Retentivity in Magmatic and Metamorphic Sphene

15:45 Oberli F, Bachmann O, Meier M \& Dungan MA:

The Fish Canyon Tuff: Ar-Ar Versus U-Pb Age Discrepancy Re-assessed 


\section{Symposium S24}

\section{Ocean Paleotemperatures}

\section{Convenors:}

David Lea, Ros Rickaby \& Thomas Nägler
Room B/Fo

\section{Symposium S29}

\section{Hominid Origin and Behaviour - Archeometric Approach}

Convenors:

\section{Gunther Wagner \& Peter Horn}

13:30 Budd P, Montgomery J, Evans J, Chenery C \& Powlesland D:

KEY Reconstructing Anglo-Saxon Immigration and Residential Mobility from O-, Srand $\mathrm{Pb}$-isotope Analysis

14:00 Mueller W, Fricke H, Halliday AN \& McCulloch MT:

INV EPSL Frontiers Lecture: Combined $\mathrm{Sr}, \mathrm{Pb}$ and $\mathrm{O}$ Isotopic Tracing of Origin and Migration of the Neolithic Alpine Iceman

14:15 Bocherens $\mathrm{H}$ :

INV Contribution of Biogeochemistry to the Reconstruction of Hominid Paleobiology

14:30 Trueman CNG, Behrensmeyer K, Potts R \& Tuross N:

INV Rapid Diagenesis in Bone Mineral: Mechanisms and Applications

14:45 Verri G, Boaretto E, Bordeanu C, Hass M, Paul M \& Weiner S:

INV ${ }^{10} \mathrm{Be}$ Measurements on Neolithic and Paleolithic Tools from Israel

15:00 Hoelzl S, Horn P \& Rossmann A

INV Multi-element Isotope Studies on Hominid Tissues

15:15 Minagawa $M$ :

INV ${ }^{13} \mathrm{C}$ and ${ }^{15} \mathrm{~N}$ in Bone Collagen of Prehistoric Human from Northeast Asia and North Pacific Coastal Regions, as a Clue of Dietary Analysis

14:45 Gagan M, Ayliffe $L$, Scott-Gagan $H$, Hantoro W \& McCulloch M:

INV Coral Reconstruction of Abrupt Tropical Cooling 8000 Years ago

15:00 Oba T, Yamane M \& Sagawa T:

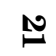

Sea Surface Temperatures off the East Coast of the Japanese Islands Since the Last Glacial Maximum Inferred from Oxygen Isotope of Foraminiferal Tests

15:15 Pearson P:

INV Eocene Meridional Temperature Gradients from Oxygen Isotopes

15:30 Lecuyer C, Picard S, Puceat E \& Sheppard S:

Mesozoic Sea Surface Temperatures of the Western Tethys Inferred from $\delta^{18} \mathrm{O}$ of Fish Teeth

15:45 Zhou G \& Zheng Y:

Oxygen Isotope Fractionation between Aragonite and Water at Low Temperatures

16:00 Martin P, Archer D \& Lea D:

INV The Role of Deep Sea Temperature Change in the Glacial Carbon Cycle

16:15 Schmidt DN, Renaud S, Bollmann J \& Thierstein HR:

Environmental Dependence of Size in Planktic Foraminifers
15:30 Pike A, Hedges R \& VanCalsteren P:

INV Providing Reliable Chronologies for Later Human Evolution: Direct Dating of Bone by U-series Disequilibrium 


\section{Symposium S30}

Biogeochemical Processes in Lakes

Convenors: Bernhard Wehrli, Liba Granina \& Jean François Gaillard

13:30 Davison W \& Motelica-Heino $M$

KEY Influence of Scale on Trace Metal Dynamics in Sediment and Water

14:00 Xue H \& Sigg L:

Complexation of Trace Metals, and Origin and Effects of Strong Ligands in Swiss Lake and River Waters

14:15 Shaked Y, Erel Y \& Sukenik A:

INV The Biogeochemistry and Speciation of Fe in the Sea of Galilee (Lake Kinneret)

14:30 Granina L:

INV Origin and Dynamics of Fe- and Mn-crusts in the Sediments of Lake Baikal

14:45 Fabian D \& Wehrli B:

Biogeochemical Cycling of Various Metals in Baldeggersee, Switzerland

15:00 Leuz A, Hug S, Moench H, Wehrli B \& Johnson CA:

The Redox Chemistry of Antimony in Lakes

15:15 Hering J:

INV Contrasting Biogeochemistry of Arsenic in Two Reservoirs on the Los Angeles Aqueduct, California, USA

15:30 Gaillard J, Taillefert M, Lienemann C \& Perret D:

N INV Trace Metals and Fe-Mn Cycling

15:45 Amrhein C, Rodriguez IR \& de Koff JP:

Geochemistry of the Salton Sea, CA
Symposium S49

$\operatorname{Room~A/Fm~}$

\section{The Geochemistry of Biogenic Minerals}

Convenors:

Anne Cohen, Patricia Dove, Nobuchimi Shimizu

\& Steve Weiner

13:30 de Villiers $S$ \& Flecker R:

INV Foraminiferal Shell Heterogeneity and Diagenesis Revealed: LA-ICP-OES as a Powerful New Tool

13:45 Cohen AL, Owens KE, Layne GD \& Shimizu N:

$\mathrm{Sr} / \mathrm{Ca}$ in Symbiotic Corals is Linked to Light Enhanced Calcification

14:00 Adkins JF:

KEY Unpacking "vital Effects" in Biogenic Carbonates using Deep-sea Corals

14:30 Sherwood OA \& Risk MJ:

North Atlantic Oscillation Record from Deep-sea Corals

14:45 McConnaughey $T$ :

KEY Heavy Isotope Deficiencies in Corals: Kinetic and McCrea Models

15:15 Auclair A, Joachimski M \& Lecuyer C:

Carbon and Oxygen Isotopic Composition of Brachiopod Shell Calcite: Physiological and Environmental Controls

15:30 Flecker R, de Villiers S, Sanchez-Almazo I \& Caruso A:

Deducing Marginal Marine Seawater Composition from Biogenic Carbonate and Evaporites

15:45 Lazar B, Stein M, Enmar R, Bar-Matthews M \& Halicz L:

INV The Effect of Diagenesis on the U System in Live and Holocene Corals from the Red Sea 


\section{Symposium G01}

\section{Special Poster Session: 19pm Geochronology}

Convenors:

Urs Schaltegger, Mike Cosca \& Jost Eikenberg

257 Anders B, Reischmann T \& Poller U:

Geochemistry and Geochronology of Basement Rocks from the Pelagonian Zone, Greece

258 Bhaskar Rao Y, Vijaya Kumar T, Anirudh Mohan D \& Janardhan A:

Significance of Deep-crustal Shear Zones in the Southern Granulite Terrain, S. India: New Nd Model Ages of Charnockites

259 Bedini RM, Blichert-Toft J, Boyet $M$ \& Albarède $F$ :

$\mathrm{Lu}$-Hf Isotope Geochemistry of Garnet-peridotite Xenoliths from the Kaapvaal Craton and the Thermal Regime of the Lithosphere

- 260 Bomparola RM, Dallai L, Belousova E, Ghezzo C, Griffin W \& O'Reilly S

U-Pb Geochronology from the Howard Peaks Intrusive Complex (Northern Victoria Land - Antarctica): New Evidence for Magmatic Age and U-Pb Resetting in Zircons

261 Brauns M \& Haack U:

Re/Os-Studies of the German Kupferschiefer

262 Celik F \& Delaloye M:

New ${ }^{40} \mathrm{Ar} /{ }^{39} \mathrm{Ar}$ and $\mathrm{K}-\mathrm{Ar}$ Age Implications and Geochemical Constrains on Metamorphic Rocks of the Tauride Belt Ophiolites (Southern Turkey)

¿ 263 Cheong C, Choi M, Khim B, Sohn Y \& Kwon S:

${ }^{230} \mathrm{Th} /{ }^{234} \mathrm{U}$ Dating of Fossil Mollusc Shells from Jeju Island, Korea by Multiple Collector Inductively Coupled Plasma Mass Spectrometry

264 Di Vincenzo G, Viti C \& Rocchi S:

The Role of Chlorite Interlayering on ${ }^{40} \mathrm{Ar}^{-39} \mathrm{Ar}$ Biotite Dating: $\mathrm{An}{ }^{40} \mathrm{Ar}-{ }^{39} \mathrm{Ar}$ Laserprobe and TEM Investigation of Variably Chloritised Biotites Hajdas I:

Variations in Atmospheric ${ }^{14} \mathrm{C}$ Content and Implications for Dating

First Evidence for Silurian Magmatism in the Serbo-Macedonian Massif, Northern

$$
\text { Greece }
$$

267 Horst Z \& Mancktelow N

K-Ar Dating of Alpine Fault Gouges

268

Iwata N, Takigami Y \& Lin A:

${ }^{40} \mathrm{Ar}^{-39} \mathrm{Ar}$ Age of a Fresh Glassy Pseudotachylite from the Fuyun Fault Zone, Northwest China

269 Kaulina T:

Metasomatic Alteration of Zircons from Potassic Granites

270

Kim C, Chang H \& Turek A:

Early Proterozoic Continental Growth in the Gyeonggi and Ryeongnam Massifs, Korea

271 Krymsky R:

$\mathrm{Pb}-\mathrm{Pb}$ Evaporation Method on Native Gold Grains

272 Kudryashov N \& Gavrilenko B:

Geochronology Archaean Kolmozero-Voron,ya Greenstone Belt of the Kola Region (North-Eastern Baltic Shield)
273 Lan C, Chung S, Lo C \& Lee T:

Crustal Evolution of SE Asia: A Perspective from Vietnam

274 Marbach T, Kober B \& Mangini A:

Granite Alteration Processes Determined by Sr- Pb-Isotopes and Th/U Disequilibria

275 Murakami M, Yamada R \& Tagami T:

Detection of Frictional Heating of Fault Motion by Zircon Fission Track Thermochronology

276 Ovtcharova M, Cherneva Z, von Quadt A \& Peytcheva I:

Migmatitic Geochronology and Geochemistry - a key to Understanding the Exhumation of the Madan Dome (Bulgaria)

277 Ozawa A, Garcia M \& Tagami T:

K-Ar Age Determination on Honolulu Unit, Oahu, Hawaii

278 Rosa MdLdS, Conceição H, Marinho MM, Macambira MJB \& Marques LS: Geochronology of the South Bahia Alkaline Province (NE Brazil)

279 Rotolo SG, De Gregorio S \& Villa IM:

Geochronology of the Peloritani Mountains (Sicily): Hercynian, pre-Hercynian, but not Alpine

280 Sagong $H$, Cheong C \& Kwon S:

Paleoproterozoic Orogeny in South Korea: Evidence from Sm-Nd and Pb Stepleaching Garnet Ages of Precambrian Basement Rocks

281 Salnikova E, Kotov A, Yakovleva S \& Kovach V:

Age, Sources and Geodynamic Setting of the Paleoproterozoic Granitoids in the Western Aldan Shield (Eastern Siberia)

282 Sato K, Tatsumi Y, Prikhodko V \& Bretstein Y:

Cenozoic Volcanism in Sikhote Alin, Russia: Transition of Magma Type Associated with Backarc Opening

283 Schneider J, Heijlen W, Muchez P \& Haack U:

$\mathrm{Rb}$-Sr Dating of Sphalerites from Pomorzany, Upper Silesia (Poland)

284 Schwarz W \& Lippolt HJ:

Dating of Hydrothermal Alteration by the ${ }^{40} \mathrm{Ar}{ }^{39} \mathrm{Ar}$ Step Heating Method using Plagioclase-sericite Intergrowth

285 Sorokin A \& Ponomarchuk V:

Umlekan-Ogodzha Early Cretaceous Magmatic Belt (North Margin of the Amurian Superterrane): Duration of Magmatism and Tectonic Implications

286 Takigami Y, Sakai H \& Orihashi Y:

1.5-1.7 Ga Rocks Discovered from the Lesser Himalaya and Siwalik Belt: ${ }^{40} \mathrm{Ar}-{ }^{39} \mathrm{Ar}$ Ages and their Significances in the Evolution of the Himalayan Orogen

287 Todt W, Poller U, Janák M \& Kohút M:

Metamorphic Evolution of the Western Tatra, Slovakia: New Geochemical and Geochronological Data

288 Trombetta A, Cirrincione R, Corfu F, Mazzoleni P \& Pezzino A:

Zircon U-Pb Ages of Porphyroids of the Peloritan Mountains (NE Sicily) Constraints on the pre-Variscan Evolution of the Peloritan Microplate

289 von Quadt A, Peytcheva I \& Heinrich C:

Life Span of a Cu-(Au-PGE) Porphyry Deposit using High-precise U-Pb Single Zircon Dating, Example: Elatsite, Bulgaria (Bulgaria)

290 Yamada K \& Tagami T:

Experimental Study on Hydrothermal Annealing of Fission Tracks in Zircon 


\section{Symposium G03}

\section{Special Poster Session: 19pm \\ Climate Change}

\section{Convenors:}

\section{Miriam Andres \& Christian Schlüchter}

226 Chen J \& Wan G:

Recent Climatic Change and its Chemical Records in Lake Erhai

227

Cenozoic Magmas Monitor Climate Change in Northern Victoria Land, Antarctica

Thenfeld C, Mas R, Gagan M, Norman M \& Henderson G:

Seasonal Trace Element and Isotope Variations in Freshwater Tufas: Potentials and Limitations for Climate Reconstruction

229 Kashiwagi H \& Shikazono N:

Climate Change in Cenozoic Inferred from Carbon Cycle Model

230 Yu LT \& Wang S:

Source of Soil $\mathrm{CO}_{2}$ from Carbonate Dissolution and Organic Decomposition in Karst Area - Evidence from Carbon Isotope

231 Lojen S, Vokal B, Papesch W, Cukrov N \& Mihelcic G:

Tufa Barriers and Laminated Carbonate Incrustations in Krka National Park, Croatia, as Modern Climate Indicators

232 Maheshwari A \& Sial A

C-isotope Composition of Delhi Supergroup, India: Implications for Mesoproterozoic Oceanic C Isotope Evolution

233 Major C, Goldstein SL, Ryan WBF, Piotrowski A \& Lericolais G:

Climate Change in the Black Sea Region Through Termination I from Sr and O Isotopes 234 Rao W:

Paleoclimate Record of Variation of the Organic Carbon in Chinese Loess Section Since 0.15 Ma B.P

235 Serefiddin F, Schwarcz HP \& Ford DC

Paleotemperature Reconstruction using Isotopic Variations in Speleothem Fluid Inclusion Water

236 Tang S \& Chen J:

Climate Changes in Southwest China during the Past 700 Years

237 Treble P, Harrison T, Shelley J, McKeegan K, Grove M \& McCulloch M:

High Resolution Trace Element and Oxygen Isotope Analyses of a Modern Speleothem

238 Vautravers M, Shackleton N \& Gruetzner J:

Millennial Scale Variability Records in Western Subtropical Atlantic Ocean

Wang F, Liang X \& Liu C:

The Correlation of Inorganic C, O Isotopic Composition of Chenghai Lake Sediments and its Environmental Implications

Palaeoclimatic Records from Blanket Mire at the QingHai-Tibetan Plateau, China

A Remarkable Climate Shift Around 1700 1500 a BP and its Significance in the Climate Prediction of the Coming 500 Years

\section{Symposium G07}

\section{Geochemistry of Pollution}

Special Poster Session: 18pm

Malcolm McCulloch \& Björn Öhlander

Convenors:

\section{S \& Jocelyne H:}

A20 Abrajano T, Stark A, Janice S \& Jocelyne H:
Molecular and Carbon Isotopic Characterization of Polycyclic Aromatic Molecular and Carbon Isotopic Characterization of Polycyclic Aromatic
Hydrocarbon Distribution in Mussels and Associated Sediments from the Massena-Cornwall Area, St. Lawrence River

321 Bessonova $\mathrm{E} \&$ Gaskova O:

Geochemical Estimation of Environment Impact of Co-Ni-As Tailings

322 Bohlin H, Mörth C \& Holm NG:

Nitrogen and Carbon Isotopes, and Metals in Waste Work Sediments, Kovik, Sweden

323 Bojakowska I:

Polycyclic Aromatic Hydrocarbons in Materials of Burned Peatbogs

324 Castrec-Rouelle M, Mandengyogo M, Dülz M, Ponthieu M \& Benedetti M:

$\mathrm{Cu}$ and $\mathrm{Zn}$ Transfer in an Ecosystem Impacted by Pig Manure: Soil and Soil Solution Data

325 Charlet L, Peretyashko T, Grimaldi M \& Bosbach D:

Reduction of Mercury by Surface Fe(II) and the Formation of $\mathrm{Hg}^{\circ}$ in Hydromorphic Soils

326 Cundy AB, Croudace IW, Warwick PE \& Oh J:

Geochemical and Hydrodynamic Controls on the Accumulation of Nuclear Reprocessing Wastes in Coastal Sediments

327 Dolenec T \& Vokal B:

Nitrogen 15 Signals of Antropogenic Nutrient Loading in Anemonia sulcata from the Adriatic Sea

328 Dongarrà G, Sabatino G \& Varrica D:

Heavy Metals in Road Dust and Vegetation from the Urban Area of Messina (Italy) 329 Feng X, Tang S, Shang L \& Yan H:

Total Gaseous Mercury Exchange between Air and Water Surface over Baihua Reservoir in Guiyang, China

330 Fernández-González Á, Andara Á, Pedreira V \& Prieto $M$ :

Sorption of $\mathrm{Pb}^{2+}$ on Barite and Crystallisation of $(\mathrm{Ba}, \mathrm{Pb}) \mathrm{SO}_{4}$ in Aqueous Environments

331 Gleisner M \& Herbert R:

Comparison of Sulfide Oxidation in Unweathered Pyritic Mine Tailings

332 Goncalves M, Nogueira JM, Putnis C \& Figueiras J:

Metal and Micro-organic Pollutant Partitioning between Sediments and Waste Waters from a Landfill

333 Gresch M, Oschwald P, Rytz I, Sydler P, Wettstein B \& Mergenthaler B:

Antimony and Lead Pollution in the Soil of Shooting Ranges

334 Hissler C \& Probst J:

Mercury Pollution in the Thur River Basin (North-East of France): DOC and Chloride Concentration Control on Mercury Partitioning between Dissolved and Particulate Phases 
Irina K, Vasiliy S, German B \& Yury S:

The Distribution of the Cs, Sr, U in the Chernobyl Clay-sandy Grounds: The Thermodynamic Model Development and Testing

336 Lee $\mathrm{S} \&$ Chung $\mathrm{J}$ :

Geochemistry of the Porewater in the Soils Near Mine Tailing Disposal Site

337

JE, Kim Y \& Choo CO:

Geochemical Characteristics of AMD from Dalsung Tungsten Mine, Korea

338

Thermochemistry of Poorly Crystalline Iron Oxides

339 Manfra L, Alessio M, Anselmi S, Conforto L, Improta S \& Manes F:

Carbon Isotopes in Detecting Urban Pollution in Rome

340 Ozherelieva N:

Features of Metals Distribution in the Bottom Sediments of the Malaya Talmovay River

341 Pasilis S \& Pemberton JE:

Speciation and Surface Interactions

342 Ponthieu M, Juillot F, Morin G \& Benedetti M.

Metal Ion Speciation in Smelter Impacted Soils and Soil Solution

343 Roman-Ross G, Cuello G, Tisserand D \& Charlet L:

Arsenic Removal by Gypsum and Calcite: The Continuum between Sorption and Solid-solution Phenomenon

344 Tsunoda T, Suzuki A, Kawahata H \& Shikazono N:

$$
\text { the Ryukyus, Japan }
$$

Majzlan J, Bender Koch C \& Navrotsky A

Symposium G08

Geochemistry of the Earth, Planets and Meteorites

\section{Convenors:}

Der-Chuen Lee \& Ingo Leya

155 Beck P, Gillet P, Barrat J, Jambon A \& El Goresy A:

High-pressure Silicates in Martian Meteorites

156 Frisia S, Borsato A, Mackenzie FT \& Tomasoni R:

Dissolution Experiments and Natural Weathering of Carbonates

157 Gnos E, Hofmann B, Villa IM \& Al-Kathiri A:

Sayh al Uhaymir 094 - A New Martian Meteorite from the Oman Desert

158 Oba M, Mita H \& Shimoyama A:

Determination of Kinetic Parameters for Individual Compounds on Release from Kerogen by Thermal Analysis

\section{Symposium G09 \\ Special Poster Session: 19am \\ Geochemistry and Mineral Physics}

345 Valentino GM:

Barite Dissolution Rates Measured with Different Methods

346 van Gaans PF:

How to Assess Controls of $\mathrm{Al}$ in Acidified Soil Solution

347 Warwick P, Croudace IW, Howard AG, Cundy AB \& Morris J:

Spatial and Temporal Variation of Tritium Activities in Coastal Marine Sediments of the Severn Estuary, U.K

348 Williams G, Harrison I, Noy D, Dumplton S, Carlick C \& Crowley O:

Natural Attenuation of Chiral Mecoprop in a Fractured Limestone Aquifer

Wingenfelder U, Furrer G \& Schulin R:

Heavy Metal Uptake by Natural and Modified Zeolites

350

Max Schmidt \& Martin Kunz

\section{Convenors:}

110 Boily J \& Seward TM:

Hydrolysis and Precipitation of Pd(II) in $0.6 \mathrm{M} \mathrm{NaCl}$

111 Chien Y, Mucci A, Paquette J \& Vali H:

The Influence of Ionic Strength and Magnesium Ions on Calcite Crystal Growth Morphology

112 Choo CO \& Kim Y:

SEM, FTIR, and NMR Studies of Dumortierite from an Al-rich Clay Deposit, Korea

113 Gunter M \& Palmer J:

Combined Sr and Cs Exchange in a Natural Clinoptilolite

114 Guozhi W \& Ruizhong H:

A Kinetic Experiments of Oxidation of Arsenopyrite in $\mathrm{Fe}_{2}\left(\mathrm{SO}_{4}\right)_{3}$ Solutions

Geochemical Information of Ore Fluid from Fluorite in Qinglong Antimony Deposit, Southwest Guizhou, China

115 Igarashi C \& Shikazono N:

Comosition of Sound Producing Sand in Japan

116 Jersek M, Dolenec T, Vokal B, Mirtic B, Zebec V \& Bermanec V: Correlation between Morphology and Isotopic Composition of Oxygen and Carbon of Calcite from Mezica Mines, Slovenia

117 Ji H, Wang S, Ouyang Z, Zhang S \& zhou D:

$\mathrm{Nd}-\mathrm{Sr}$-Pb Isotopic Compositions for red Residua Underlying Dolomites in Karst Terrains of Guizhou Province

118 Kasama T, Golla-Schindler U \& Putnis A:

Contribution of Fine Exsolution Lamellae of Hematite-ilmenite to Magnetic Properties 
$119 \quad$ Liu X \& Wang S:

Geochemical Evidence for Existence of Inland Foraminifera in the Nihewan Basin, China

120 Mirtic; B, Jersek M, Resnik A, Dolenec T \& Krivograd F

Morphological Characteristics of Fluorite Crystals from Mezica Mines in Northern Slovenia

121 Mladenovic A, Sturm S, Mirtic B \& Strupi Suput J:

The Alkali Silica Reaction of Different Natural Aggregates in Cement Mortars

122

Ogawa Y, Shikazono N, Ishiyama D, Sato H \& Mizuta T:

Water-rock Reaction Experiments for Application to the Formation Mechanism of Kuroko Deposits

123 Ohta A, Tsuno H, Kagi H \& Nomura $M$ :

XAFS Characterization of La and Nd Coprecipitated with Mn Dioxide and Fe Oxyhydroxide

124 Ootani H \& Shikazono N:

Geochemical Behavior of Minor and REE Elements in Loam and Andosol

125 Peng J, Hu R, Zhao J \& Qi L:

The Dramatic Fractionation of REEs in Hydrothermal Calcites from the Xikuangshan Antimony Deposit, Hunan, China

126 Qi H \& Hu R:

REE Geochemistry of Lignites in the Lincang Germanium Deposit, Western Yunnan Procince, China

127 Reutsky V, Logvinova A \& Sobolev N:

Carbon Isotopic Composition of Macrodiamonds from Yubileinaya Pipe (Yakutia)

Stanienda K:

$\mathrm{Mg}$-calcite in Triassic Limestone of Polish Silesia

129

Superhigh Concentration of REE and Strong Negative Ce Anomalies at the Carbonate Rock Weathering Front

130 Villegas-Jiménez A, Mucci A \& Paquette J:

Re-calibration of Surface Complexation Models for Magnesite and Dolomite using Brown Valence Theory and a Genetic Algorithm

131 Wang S, Ji H, Ouyang Z, Zhang S, Sun C \& Zhou D:

REE Geochemistry in the Weathering Front of red Residua Underlying Dolomites in Pingba County, Guizhou Province

132 Xie G \& Hu R:

Origin of Lamprophres in the Xikuangshan Antimony Deposits, Hunan, P.R. China: Evidence for Combined Trace Element with $\mathrm{Sr}$ and $\mathrm{Nd}$ Isotope Studies

133 Zangooi A:

Annite: Magmatic Evolution and Subsolidus Alteration in Nepheline Syenites, Mount Saint-Hilaire, Quebec, Canada

134 Zedgenizov D, Reutsky V, Shatsky V \& Fedorova E:

A Comparison of Carbon Isotope Composition and Impurity Defects of Microdiamonds of Octahedral and Cubic Habit from Udachnaya Kimberlite Pipe (Yakutia)

Symposium S01

\section{Presolar Grains and Gases}

Special Poster Session: 19am

Convenors:

Uli Ott \& Larry Nittler

142 Holland G, Gilmour J, Verchovsky S \& Turner G

Xenon Isotopes in Nanodiamonds

143 Kashiv Y:

Kinetics of the Condensation of Presolar SiC and its Trace Elements

144 Kitts K, Nichols, Jr. RH \& Podosek FA:

Megascale Isotopic Anomaly in $\mathrm{Cr}$

145 Mostefaoui S, Besmehn A \& Hoppe P:

The First Presolar Corundum in an Enstatite Chondrite: A NanoSIMS Study

146 Mukhopadhyay S, Nittler L \& Brownlee D:

Sulfur Isotope Imaging of Interplanetary Dust Particles

147 Mutschke H, Andersen AC, Jäger C \& Henning T:

Optical Constants of Presolar Diamonds (Revisited)

Symposium S02

\section{Stars, Disks and Planetary Growth}

Convenors:

Brigitte Zanda, Conel Alexander, Herbert Palme

\& Ed Young

148 Busfield A, Holland G, Bridges J, Gilmour J \& Turner G:

I-Xe Analyses of Chainpur Chondrules

149 Ebihara M, Hayano K \& Noguchi T:

REE, Th and U Abundances in Individual Chondrules from Dhajala, Allegan and Bjurböle Chondrites

150 Galli A, Whitby J \& Benz W:

Dust Settling and Aggregation in the Protosolar Nebula

151 Poitrasson F, Teutsch N, Levasseur S, Lee DC \& Halliday AN:

Iron Isotope Signature of the Inner Solar System

152 Qingzhu $Y$ :

Isn't the Moderately Volatile Element Depletion in the Inner Solar System Inherited from Interstellar Dust?

153 Snytnikov V, Parmon V, Nikitin S, Vshivkov V, Gleaves J \& Yablonsky G: Space Chemical Reactor of Protoplanetary Disk 


\section{Symposium S05}

Special Poster Session: 18pm

Source of Organic Compounds on the Early Earth and Other Solar System Bodies

Convenors:

Gerda Horneck \& André Brack

163 Lemke KH, Ross DS, Bischoff JL, Rosenbauer RJ \& Bird DK:

Hydrothermal Stability of Glycine and the Formation of Oligoglycine: Kinetics of Peptide Formation at $260^{\circ} \mathrm{C}$ and 200 Bars

164 Naraoka H, Mita H, Komiya M \& Shimoyama A:

DD of Individual PAHs from the Murchison and an Antarctic Carbonaceous Chondrite

165 Pearson VK, Kearsley A, Sephton M \& Gilmour I:

Locating Organic Material in Carbonaceous Chondrites

\section{Symposium S07}

Special Poster Session: 19pm

\section{Archean and Proterozoic Oceans, Climates, and} Geochemistry

Convenors: Balz Kamber, Dan Schrag, Minik Rosing \& Don Canfield

166 Chapman H, Bickle MJ, Hunter M, Fowler M, Nisbet E \& Martin T:

Banded Iron Formations as Monitors of Archaean Seawater Composition

167 Kasemann SA, Hawkesworth CJ \& Prave AR:

Kasemann SA, Hawkesworth CJ \& Prave AR:
Calcium Isotope Variation in Neoproterozoic Carbonate Rocks

168 Khabarov E, Ponomarchuk V \& Morozova I:

$\delta^{13} \mathrm{C}-{ }^{87} \mathrm{Sr} /{ }^{86} \mathrm{Sr}$-evolution Trends of the Meso-Neoproterozoic Carbonate Deposits: West Margin of the Siberian Craton

169 Morel P, Byerly GR, Lowe DR \& Kramers JD:

Re-Os Systematics of Archean Spherule Layers from the Barberton Greenstone Belt

A

C Isotopes in Early Paleoproterozoic Carbonate Rocks from the Minas Supergroup, Minas Gerais, Brazil

171 Stafford S, Capo RC, Stewart BW, Marmo J \& Ohmoto H:

Paleoenvironmental Investigation of the Proterozoic Hokkalampi Paleosol, Eastern Finland

172 Stewart B, Bau M \& Capo R:

Neodymium Isotope Investigation of 2.6 Ga Hamersley Group Carbonate, Western Australia

173 Yamaguchi $K$, Naraoka $H$, Watanabe $Y \&$ Ohmoto $H$ :

The Early Evolution of the Archean Nitrogen Biogeochemical Cycle
Symposium S11

Special Poster Session: 18am

\section{Mantle Melting and Magma Transport}

Convenors:

Pierre Schiano \& Paul Asimow

044 Ashchepkov I, Nikolai V, Roger M, Howard C, Anatoliy S \& Gennadiy A:

Geochemical Evidence for Multistage Melt Percolation in Mantle Keel beneath Wyoming Craton

045 Bouhedja M, Wagner C, Deloule E \& Reisberg L:

Mechanisms of Melt Migration and Mantle Metasomatism in the Lithosphere beneath the French Massif Central

046 Du Y, Qin X, Zhou W \& Zhang H:

The Mesozoic Mantle-derived Magma Underplating and Magmatic Processes in the Tongling Area, Anhui Province

047 Font L, Murton B, Roberts S \& Tindle A:

Melt and Source Diversity Under the Ultra Slow Spreading Southwest Indian Ridge Knight K, Baker J, Renne P, Halkett A \& White N:

Geochemical Clues on the Origins of Rajahmundry Trap Basalts, India

049 Nüsslein M, Griesshaber E \& Job R:

$\mathrm{CO}_{2}$ Fluxes from the Mantle Plume in the Eifel

050 Rapaille C, Marzoli A, Bertrand H, Feraud G, Reisberg L \& Fontignie D: Geochemistry and Age of the European CAMP Basalts

051 Safonov O, Perchuk L, Litvin Y \& Matveev Y:

Formation of Potassium-bearing Clinopyroxene in Potassic Mantle-derived Liquids

052 Snow JE, Dick HJB, Hellebrand E, Büchl A, von der Handt A \& Langmuir C: Geochemistry of Abyssal Peridotites from Gakkel Ridge, Arctic Ocean

053 Sobolev R:

Kinetics of Melts Crystallization

054 Su W, Hu R, Liu X, Qi L \& Bi X:

Mantle Metasomatism and Platinum-group Elements Fractionation: Evidence from Deep-source Xenoliths at Liuhe, Yunnan, China

055 Sushchevskaya N \& Belyatsky B:

Magmatism of the Indian and Atlantic Oceans as a Consequence of Deep Mantle Plumes Activity

056 Warren JM, Shimizu N \& Dick H:

High Pressure Melt Impregnation in a Mantle Peridotite 
Symposium S12

Special Poster Session: 19pm

\section{Mantle Volatiles: Primordial v Recycled}

\section{Convenors:}

Pete Burnard, Bernard Marty \& Mike Carroll

034 Demény A, Vennemann T, Hegner E, Embey-Isztin A, Homonnay Z \& Milton A:

Trace Element and Isotopic Evidence for Subduction-related Carbonate-silicate Melts in Mantle Xenoliths from the Pannonian Basin, Hungary

035 Kronz A, Jacob D, Cartigny P \& Viljoen F:

Cohenite (Iron Carbide) and Native Iron Formation within Garnet Included in Polycrystalline Diamonds by Redox Freezing in the Cratonic Lithosphere

036 le Roux P, Shirey S, Hauri E, Perfit M \& Mock T:

Degassing \& Preliminary Assimilation Histories of Selected on- and Off-axis EPR MORB Glasses $\left(8-10^{\circ} \mathrm{N}, 12-14^{\circ} \mathrm{N}, \& 15-16^{\circ} \mathrm{N}\right)$

037 Michael PJ \& Kamenetsky VS

Low $\mathrm{H}_{2} \mathrm{O}$ in the LOMU Source of Oceanic Magmas: Inferences from a South Atlantic Submarine Glass

$038 \quad$ Pilz $P$, Hammerschmidt $K$ \& Niedermann S:

MORB-like ${ }^{3} \mathrm{He} /{ }^{4} \mathrm{He}$ Ratios in Olivines from the Back-arc of the South American Central Volcanic Zone

039 Pineau F, Jendrzejewski N, Aubaud C, Appora I, Shilobreeva S \& Javoy M:

Carbon Isotopes in Basaltic Magmas, Processus or Source Signature ?

040 Sapienza G, Hilton D \& Scribano V:

He Isotopes in Peridotite Xenoliths from Sicily, Southern Italy

041 Wiersberg T, Niedermann S \& Erzinger J:

Fluid-rock Interaction of Kimberlites on the Base of their Noble Gas Composition

042 Wysoczanski R, Hauri E, Gamble J, Luhr J, Eggins S \& Wright I:

Volatile Elements in Pillow Lava Glasses from the Kermadec Arc - Havre Trough and Offshore Taupo Volcanic Zone, Southwest Pacific

043 Zaitsev A, Demény A, Wall F, Sindern S, Sitnikova M \& Karchevsky P:

Carbon and Oxygen Isotope Compositions of Carbonatite Complexes from the Kola Peninsula, Russia
Symposium S13

Special Poster Session: 19am

Subduction Factory: From Ocean to Mantle

\section{Convenors:}

Derrill Kerrick \& Peter Ulmer

015 Deyhle A \& Kopf A:

The use of Boron Isotopes in Natural Silicate-water Systems

016 Foley S, Tiepolo M \& Vannucci R:

Trace Element Partitioning Evidence for Growth of Early Continental Crust from Amphibolites, not Eclogites

017 Forneris J \& Holloway JR:

Stability of Hydrous Minerals in Subducting Eclogitized Crust: New Experimenta Perspectives

018 Hort M, Rüpke L \& Phipps Morgan J:

What Causes the Geochemical Diversity of Arc Lavas?

019 Savov I, ryan J, Chan L, D’Antonio M, Mottl M \& Fryer P:

Geochemistry of Serpentinites from the S.Chamorro Seamount, ODP Leg 195, Site 1200, Mariana Forearc- Implications For Recycling at Subduction Zones

020 Yeh G, You C, Chen J, Yang T, Chen Y \& Song S:

Fluid Geochemistry of Mud Volcanoes at the Accretionary Prism in Southern Taiwan

021 Zheng Y, Li L, Zhao Z \& Gong B:

Oxygen Isotope Mapping of UHP Metamorphic Rocks in the Dabie-Sulu Orogen of China 


\section{Symposium S14}

Characterising Slab, Mantle and Crustal Contributions to Arcs

\section{Convenors:}

\section{Mike Dungan \& Jon Davidson}

001 Antignano IV A \& Rushmer T:

Tonalite Generation in Arc Regimes: Results from Metadiorite Partial Melting Experiments

002 Beccaluva L, Bianchini G, Coltorti M, Del Moro A, Siena F \& Vaccaro C:

A Rare Case of Subduction-related Metasomatism in Mantle Xenoliths from the Betic Area (South Spain)

003 Chiaradia M \& Fontboté L:

Lead Isotope Evidence for Latitudinal Mantle Heterogeneity beneath the Andes,

$\stackrel{\circ}{Ð} 004 \quad$ Franciosi L, Lustrino M, Melluso L, Morra V \& D'Antonio M:

The Role of Metasomatising Fluids in the Genesis of Orogenic Magmas. A Case Study from Sardinia, Italy

Isotopic Constraints on the Origin of the Bushveld Complex Magmas in a Back-arc Environment

006 Nicolaysen K, Weis D, Scoates JS \& Myers JD:

Nicolaysen K, Weis D, Scoates JS \& Myers JD:
Sediment Subduction and Magma Genesis in the Central Aleutian arc

으 007 Nishio Y, Nakai S, Hirose K, Ishii T \& Sano Y:

Li Isotopic Systematics of Volcanic Rocks in Marginal Basins

$008 \quad$ Nohda S, kani T \& Otofuji Y:

$\mathrm{Pb}$ Isotopic Characteristics of the Tertiary Volcanic Rocks Observed in the Japan Sea Side of Northeast Japan

009 Ponomareva V, Bindeman I, Fournelle J \& Valley J:

The Impact of Last Glaciation on Volcanism in N. Pacific Arcs

010 Rosner M, Erzinger J \& Trumbull R:

Isotopic Crustal and Slab Fingerprints in Arc Volcanic Rocks from the Central Volcanic Zone of the Andes

011 Senda R, Kachi T \& Tanaka T:

$\mathrm{Sr}$, Nd and Os Isotopic Systematics of Nikubuchi Ultramafic Complex in Central Shikoku, Japan

012 van der Meer JPM, van Bergen MJ, Vroon PZ \& Davies GR:

INV Sr-Nd-Pb Isotope Constraints on Magma Genesis in the Sangihe Arc, North Indonesia

013 Yanagi T, Nakada M, Issiki H \& Maeda S:

Lower Crustal Renewal Associated with Formation of Sedimentary Basins and Arc Volcanism in the Middle to Late Cenozoic in Japan

014 Yokoyama T, Kobayashi K, Kuritani T \& Nakamura E:

Mantle Metasomatism and Rapid Ascent of Slab Components beneath Miyakejima Volcano, Izu Arc, Japan

\section{Symposium S15}

Special Poster Session: 19am

Trace Element Fingerprinting: Laboratory Studies and Petrogenetic Processes

Convenors:

Sue O’Reilly \& Ricardo Vannucci

059 Cottin J, Delpech G, Zerka M, O'Reilly SY, Gregoire M \& Lorand J:

Trace-element Variations and Melt Percolation within Mantle Xenoliths from Algeria

060 Dietzel M, Gussone N \& Eisenhauer A:

Precipitation of Aragonite by Membrane Diffusion of Gaseous $\mathrm{CO}_{2}$ and the Coprecipitation of $\mathrm{Sr}^{2+}$ and $\mathrm{Ba}^{2+}\left(10^{\circ}\right.$ to $\left.50^{\circ} \mathrm{C}\right)$

061 Fu S \& Gu X:

$\mathrm{Rb}-\mathrm{Sr}$ Isotopic Dating and its Genetic Significance to the Manaoke Gold Deposit, NW-Sichuan, China

062 Gu X, Schulz O, Vavtar F \& Liu J:

Rare Earth Element Geochemical Constraints on the Genesis of the Woxi W-Sb-Au Deposit, South China

063 Lee S, Kim Y, Lee D \& Chae B:

The Change of REE Patterns from Gneiss Core in Boreholes, Namyangju and Cheongyang Area, Korea

064 Marzoli A, Bussy F \& Jourdan F:

Parental Magmas and Crustal Contamination of Tholeiitic Basalts as Revealed by Mineral Major and Trace Element Compositions

065 McDade P, Wood B \& Blundy J:

McDade P, Wood B \& Blundy J:
Experimental Determination of Near-solidus Peridotite Trace Partition Coefficients 066 Mocek B, Ioniov D \& Boyd J:

Element Partitioning and Chemical Zoning in Minerals from Garnet Peridotites

067 Powell W, O'Reilly S, Griffin W \& Massimo T:

Trace Element Distribution between Coexisting Clinopyroxene and Amphibole in Xenoliths from Western Victoria, Australia

068 Scambelluri M, Muentener O, Ottolini L, Pettke T \& Vannucci R:

Boron and Chlorine Cycling in the Subducted Hydrous Oceanic Mantle

069 Wittenberg A, Schüßler J \& Koepke J:

Kinetic Studies on the Trace Element Distribution of Ca-Al-rich Silicates 


\section{Symposium S20}

Linking Geochronology with Petrology and Textures

\section{Convenors:}

Wolfgang Müller \& Derek Vance

$024 \quad$ Akinin V, Miller E \& Wooden J:

SHRIMP Dating of Lower Crust Xenoliths from Bering Sea Region

025

Bhattacharya $S$ :

Isotopic Data from Granulites of the Eastern Ghats Belt, India, Linked to Petrological Processes Through Textural Evidence

026 Carosi R, Di Vincenzo G \& Palmeri R:

The Relationship between Metamorphic Evolution and Argon Isotope Records in White Mica: Constraints from the Variscan Basement of Sardinia (Italy)

027 Prostyakov K, Travin A, Lepezin G, Volkova N \& Yudin D:

A Reconstruction of the Thermal History of the UHP Maksyutov Complex (South Urals) using ${ }^{40} \mathrm{Ar} /{ }^{39} \mathrm{Ar}$-dating Results

028 Vadlamani R, Y.j. BR \& Kunchitapadam G:

P-T-t History of Granulites from the Schirmacher Oasis, East Antarctica

029 Schneider D \& Holm D:

Timing of Metamorphism and Stabilization of Paleoproterozoic Laurentia

\section{Symposium S23 \\ Special Poster Session: 19pm \\ Ocean Productivity: Past and Present}

\section{Convenors: Martin Frank, Stefano Bernasconi \& Kimitaka Kawamura}

201 Andrew AS, Whitford DJ, Jeppson L, Talent JA, Mawson R \& Simpson AJ:

The Late Silurian Lau Event: Isotopic Evidence for Causes of Extinction

202 Christl M, Siegle S, Strobl C, Reuter S \& Mangini A:

Distribution and Sedimentary Flux of ${ }^{10}$ Beryllium, ${ }^{230}$ Thorium, and ${ }^{231}$ Protactinium in the South Atlantic Ocean on a Glacial / Interglacial Timescale; A Multibox Model Approach

203 Dolenec M, Ogorelec B \& Lojen S:

Isotopic Fractionation between Carbonate and Organic Carbon as Evidence of a Productivity Crash at the P/Tr Boundary in the Idrijca Valley (W Slovenia)

204 Dubinin A \& Sval'nov V:

Manganese Micronodule Composition as Possible Indicator of Biological Productivity of the Ocean

205 Geibert W \& Usbeck R:

The Adsorption of Th and Pa on Different Particle Types in Dependence of the Provenance of Natural Seawater

206 Latimer J \& Filippelli G:

Phosphorus Geochemistry and Export Production Across the Polar Front Zone in the Southeastern Atlantic Ocean

207 Nakanishi $T$ \& Minagawa $M$

Seasonal Variability of Biomarkers in Sinking Particles in the Japan Sea

208 Niggemann J, Kallmeyer J \& Schubert C:

Sediments in the Peruvian Upwelling Region: Organic Matter Composition and Sulfate Reduction Rates

209 Scholten J, Fietzke J, Mangini A, Stoffers P \& Ittekkot V:

Seasonal and Spatial Controls of ${ }^{230} \mathrm{Th} /{ }^{231} \mathrm{~Pa}$ Ratios in the Arabian Sea

210 Yamada M \& Aono T:

Seasonal Variation of ${ }^{231} \mathrm{~Pa}$ and ${ }^{230} \mathrm{Th}$ Fluxes in the West Caroline Basin 
Symposium S24

\section{Ocean Paleotemperatures}

\section{Convenors:}

David Lea, Ros Rickaby \& Thomas Nägler

211 Gussone N, Eisenhauer A, Haug G, Tiedemann R, Müller A \& Heuser A:

$\delta^{44} \mathrm{Ca}, \delta^{18} \mathrm{O}$ and $\mathrm{Mg} / \mathrm{Ca}$ Ratios Reveal Sea Surface Temperature (SST) and Sea Surface Salinity (SSS) Variations during the Emergence of the Central American Isthmus

212 Korte C, Jasper T, Kozur HW \& Veizer J:

$\delta^{18} \mathrm{O}$ of Permian and Triassic Brachiopods: Implications for Coeval Seawater and Paleotemperatures

213 Lynch-Stieglitz J, Liu Z, Koutavas A, Marchitto T \& Brady E:

Sea Surface Temperature Patterns in the Early Holocene: Global Ocean Response to Insolation Forcing

Geochemical Expressions of Early Marine Diagenesis in Corals - Implications for Paleoceanographic Reconstructions

215 Paul HA, Swart PK, Bernasconi SM, Peterson LC \& McKenzie JA:

INV Tropical Sea Surface Temperature and Salinity Change in the Cariaco Basin at the Last Glacial Maximum

\section{Symposium S30}

\section{Special Poster Session: 18am}

\section{Biogeochemical Processes in Lakes}

\section{Convenors: Bernhard Wehrli, Liba Granina \& Jean François Gaillard}

248 Anderson W, McFadden M, Mullins H \& Patterson W:

10,000 Year Nitrogen Isotope Record from Lake Ontario, Understanding Carbon and Nitrogen Dynamics from a Paleo-perspective

249 Canavan R, Slomp CP \& Van Cappellen P:

Trace Metal Dynamics in Freshwater Sediment: The Haringvliet

250 Hetényi M, Brukner-Wein A \& Sajgó C:

Biogeochemical Processes in Volcanic Crater Lakes and their Effect on the Oil Potential of Sediments Filling in the Craters

251 Hintelmann $\mathbf{H}$ \& Ogrinc $\mathrm{N}$ :

Pore Water Dissolved Organic Carbon Fluxes from Boreal Lake Sediments

252 Hjorth T:

Errors in Sequential Extractions of Sediments: The Freeze-drying Effect

253 Laukenmann S, Wild V, Christl M, Mangini A, Isenbeck-Schröter M \& Ilmberger J:

Redox Driven Cycling of Uranium between Sediment and Water in a Seasonal Anoxic and Sulfidic Lake

254 Reinhardt M, Müller B, Stierli R \& Gächter R:

Nutrient Retention Ponds in Agriculture - Load and Efficiency

255 Sahan E, Bottinelli M, Vazquez F, Tonolla M, Peduzzi R \& Zepp K

Chemical and Molecular Analysis of Methanogens \& SRB in Anaerobic Sediment of Lake Cadagno \& Rotsee

256 Teranes JL \& Bernasconi SM:

Carbon Cycling in Hypertrophic Lake Baldegg (Switzerland), with Implications for Eutrophic Models 
Symposium S33

Special Poster Session: 19am

The Deep Biosphere - Microbial Communities in Deeply Buried Media

Convenors:

Tim Ferdelman, Tommy Phelps \& Andreas Teske

242 Meister P, McKenzie JA, Vasconcelos C \& Leg 201 Shipboard Scientific Party Ocean Drilling Program:

Dolomite Formation on the Peru Margin: Evidence for Microbial Activity in the Deep Biosphere

243 Rock GJ, Aplin A, Matenaar I, Calvert C \& Brown A: Iron: Potential Fuel of the Deep Biosphere?

\section{Symposium S35}

Special Poster Session: 19am

\section{Molecular Tools for the Identification of Important} Geomicrobial Organisms

Convenors:

Dianne Newman \& Antje Boetius
Symposium S42

Special Poster Session: 19am

\section{Ocean Circulation: Past and Present}

Convenors:

Catherine Jeandel, Jess Adkins \& Ian Hall

217 Adkins JF, McIntyre K \& Schrag DP:

The Temperature, Salinity and $\delta^{18} \mathrm{O}$ of the LGM Deep Ocean

218 Amakawa H, Alibo D, Fukugawa K, Zhang J \& Nozaki Y:

Nd Concentration and Isotopic Ratio in the Waters of the Pacific Ocean

219 Aono T \& Yamada M:

Interannual Variability of the POC Export Flux Estimated from ${ }^{234} \mathrm{Th}$ in the Equatorial Pacific during the Period 1999 to 2001

220 Beney P, Vance D, Staubwasser M, Henderson G \& Slowey N:

Nd in Sedimentary Planktic Foraminifera Located in a Phase That Records the Nd Isotopic Composition of Surface Seawater

221 Fietzke J, Scholten J, Mangini A, Reuter S \& Stoffers P:

Distribution of ${ }^{230} \mathrm{Th}$ and ${ }^{231} \mathrm{~Pa}$ off SW-Africa

222 Jeandel C, Lacan F, Henry F, Thouron D, Olivier L \& Bénédicte M:

Water Mass Pathways off the Argentine Coast Traced by REE Concentrations and Nd Isotopic Composition

223 Norisuye K, Okamura K, Sohrin Y, Hasegawa H \& Nakanishi T:

${ }^{240} \mathrm{Pu} /{ }^{239} \mathrm{Pu}$ Isotopic Ratio in the Western Northwest Pacific Ocean

224 Scher HD, Martin EE \& Haase AA:

Circulation of Eocene to Pliocene Intermediate Water Masses in the Indian Ocean Evidence from Fossil Fish Teeth Nd Isotopes

225 Takebe $M$ \& Yamamoto $K$

What is Controlling the REE Composition of Pacific Deep Sea Sediment?

244 Croal LR, Johnson C, Beard B, Welsch S, Poulson R \& Newman DK:

Development of an Iron Isotope Biosignature for Anaerobic Photosynthetic Fe(II) Oxidizing Bacteria

245 Knittel K, Lösekann T, Boetius A, Nadalig T \& Amann R:

Diversity of Microorganisms Mediating Anaerobic Oxidation of Methane

246 McBeth J, Giles B, Ye Q, Li Y, Zhang C \& Wall J:

Fatty Acids and Stable Carbon Isotopes of a Sulfate-reducing Bacterium: Implications for Carbon Cycling in Organic-rich Marine Sediment

247 Ye Q, Fields M, Zhou J, Roh Y, Phelps T \& Zhang C:

Isolation of an Alkaliphilic Metal-reducing Bacterium from a Saline Pond Containing High Concentrations of Boron 


\section{Symposium S44}

Special Poster Session: 19am

Recent Advances in ICPMS and High-precision Isotope Ratio Mass Spectrometry

Convenors: Mark Rehkämper, Steve Galer \& Dieter Garbe-Schönberg

293 Alleman L, Cardinal D, Ziegler K \& André l:

New Developments in Measuring Silicon Isotopes by MC-ICP-MS

294 Belshaw NS, Pike AWG \& Henderson GM:

U-series Dating of Archaeological Bone Material by Laser Ablation Multiple-IonCounter ICP-MS

295 Dosso L, Taylor R \& Ishizuka O:

Interlab Comparison of Double Spike Lead Isotope Ratios for Basaltic Standards

Ehrlich S, Bar-Matthews M, Harlavan Y \& Halicz L:

$\mathrm{U}$ and $\mathrm{Pb}$ Isotope Ratios in Manganese Nodules by MC-ICP-MS

Evans D \& Dillon P.

Determination of Variations in Isotope Ratios of $\mathrm{Hg}$

298 Fretzdorff S, Garbe-Schoenberg D, Fietzke J, Livermore RA \& Stoffers P:

INV High Precision U-Series Isotope Measurements of East Scotia Back-arc Basalts using Single-Collector Sector-Field ICP-MS

299 Kinsley L, Graham M, Esat T \& McCulloch M:

Isotopic Composition of Uranium Standards and Sea-water Determined using Finnigan Neptune Multi-collector ICP-MS

300 Magna T, Wiechert U \& Halliday AN:

Lithium Isotopes and Crust-Mantle Interaction

301 Mortimer G, McCulloch M, Kinsley L \& Esat T:

High Precision ${ }^{234} \mathrm{U}{ }_{-}{ }^{230} \mathrm{Th}$ Dating using MC-ICPMS

302 Punturo R, Censi P, Lo Giudice A \& Pezzino A:

Sample Preparation and Multi-element Analysis of Geological Materials by HRICP-MS: An Application to the Building Stones of the Roman Theatre in Catania (Italy)

303 Tuttas D \& Schwieters JBS:

Advances in High Precision Isotope Ratio Measurements of Calcium using TIMS Ulfbeck D, Baker J \& Bizzaro M:

New Techniques for Separation and Analysis of Lu-Hf, Sm-Nd and the REE by MC-ICP-MS

Tarwick PE, Severmann S \& Palmer MR:

Chromatographic Extraction of $\mathrm{Fe}$ from Seawater and its Impact on Fe Isotope Fractionation

Multi-element Isotope Dilution by HR-ICP-MS

Symposium S45

Special Poster Session: 19am

Novel Approaches and New Techniques in Dating Minerals, Rocks, and Geological Processes

Convenors:

Igor Villa \& Holly Stein

030 Becker ML, Henderson GM \& Belshaw NS:

U-Th-Pb Chronology in Pleistocene Carbonates using MC-ICP-MS

031 Nemchin A \& Neymark L:

U-Pb SHRIMP Dating of Opals

032 Savatenkov $V$ \& Levsky $L$ :

Effect of Internal Sr Isotope Re-equilibration in Biotites: Implication for the Rea Thermal History

033 Wampler JM:

Stepwise Chemical Extraction of Potassium and Argon from Mica: An Alternative way to Obtain Age Spectra

\section{Symposium S47}

Special Poster Session: 19pm

\section{Microanalysis Mass-spectrometric Techniques}

\section{Convenors:}

D. Günther \& N. Shimizu

311 Bacon CR, Weber PK, Larsen KA, Hutcheon ID, Ingram BL \& Wooden JL:

INV Ion Microprobe Analysis of ${ }^{87} \mathrm{Sr} /{ }^{86} \mathrm{Sr}$ in $\mathrm{CaCO}_{3}$ and Application to Otoliths

312 Fayek M, Riciputi LR \& Kyser TK:

A New Method for U-Pb Isotopic Analyses of Uranium Oxide Minerals by SIMS

313 Gurenko A, Veksler I, Thomas R, Meixner A, Dorfman A \& Dingwell D: SIMS Study of ${ }^{11} \mathrm{~B} /{ }^{10} \mathrm{~B}$ in Immiscible Borosilicate Glasses

314 Jacobsen B, Baker J, Kent A, Peate D, Bernstein S \& Stecher O:

Comparison of Isotope Dilution and Laser Ablation REE Measurement of Geochemical Standards Reference Materials

315 Kent AJR, Joel B, Tod W, Ingrid U, Julie V \& Sophie S:

In situ Pb-isotope Analysis by LA-MC-ICP-MS: Applications to Geochemistry, Geochronology, Palaeoceanography and Archaeology

316 Reid J, Horn I \& Guenther D:

The Determination of Diffusion Profiles in Small Samples: A Comparison of Microbeam Techniques

317 Schulz M, White A, Bacon C, Weber P \& Bullen T:

SHRIMP RG Measurements of ${ }^{87} \mathrm{Sr} /{ }^{86} \mathrm{Sr}$ in Granitoid Calcites; Implications for Calcite Petrogenesis

318 Stern RA, Rayner N, Davis W, Amelin Y, Annesley I \& Bonli T:

A Method of Determining Uraninite U-Pb Ages by SHRIMP II Ion Microprobe

319 Stoll B, Jochum KP, Hofmann AW, Raczek I, Pfänder J \& Meixner A:

MPI-DING Reference Glasses for In-situ Microanalytical Techniques: New Trace Element and Isotope Data 


\section{Symposium S48}

Special Poster Session: 19pm

Small-scale Processes in Heterogeneous Environments with Relevance to Environmental Biogeochemistry

\section{Convenors: Andre Scheidegger, Ruben Kretzschmar \& Mike Hochella}

351 Birkefeld A, Nowack B \& Schulin R:

A New Method for in situ Analysis of Potentially Toxic Minerals Under Environmental Conditions

352 Claessens J, Behrends T \& Van Cappellen P:

Surface Chemistry of a Gram-negative Bacterium

353 Descostes M, Vitorge P, Mercier F \& Beaucaire C:

Pyrite $\left(\mathrm{FeS}_{2}\right)$ Oxidation at $\mathrm{pH}<3$

क 354 Dideriksen K \& Stipp S:

Characterisation of Iron Oxides in Fractured Granite

355 Fernandez-Bastero S, Gago-Duport L, Garcia T, Velo A, Villar MP \& Santos A:

XRD-Rietveld and RMC Analysis of the Aging Process in Glauconites

356 Fewless $T$ \& Luttge A.

Barite Dissolution Rates Measured with Different Methods

357 García T, Gago-Duport L, Fernández-Bastero S, Velo A, Santos A \& De la Rosa-Fox N: Estuarine-like Systems

$$
\text { Estuarine-like Systems }
$$

Godelitsas A, Astilleros J, Hallam K \& Putnis A:

Dissolution/precipitation Phenomena on Ca Carbonate Crystals Interacted with $\mathrm{Pb}^{2+}$ Ions in Aqueous Solutions

359 Gueguen C \& Guo L:

Thorium and Protactinium Sorption on Silica and Carbonate

Hyacinthe $\mathbf{C} \&$ Van Cappellen $P$

Composition and Chemical Reactivity of an Iron-Phosphorus-Manganese Phase in a Freshwater Estuarine Sediment

361 Karlby L \& Stipp S:

Substrate Preference of Bacteria

362 Luttge A, Arvidson RS, Beig MS \& Fewless TA:

Crystal Dissolution Kinetics: Is There Light at the end of the Tunnel?

363

A hindler M, Mutter A \& Putnis A:

AFM - Examinations on the Crystal Growth of Uranyl-oxide Minerals on the Surface of Calcite

364 Vasudevan D, Harrington L \& Cooper E:

Fluoride Sorption and Associated Al Release in Iron Oxide Rich Soils

365

Xifra I, Knechtenhofer L, Scheinost AC \& Kretzschmar R:

Factors Influencing the Vertical $\mathrm{Pb}$ Distribution in a Shooting Range Soil

366

Zerai B, Kadambi J \& Saylor B:

Characterization of Microscale Flow Through Porous Media during Geologic Sequestration of $\mathrm{CO}_{2}$

367 Zimmerman A, Goyne K, Chorover J, Kubicki J, Komarneni S \& Brantley S: The Effect of Mineral Mesoporosity on Amino Acid Adsorption
Symposium S49

Special Poster Session: 18pm

\section{The Geochemistry of Biogenic Minerals}

Convenors:

\section{Anne Cohen, Patricia Dove, Nobuchimi Shimizu}

\& Steve Weiner

101 Fu F, Akagi T, Suzuki Y \& Yabuki S:

REE Pattern of Carbonaceous Part of Coals: A New Proxy for the Original Plants of Coals

102 Golubev S \& Savenko A:

Solubility of Iron(III) and Aluminum Phosphates in Aqueous Solutions

103 Kodina L \& Galimov E:

Autigenic Carbonate Mineral Ikaite Originated from Biogenic Methane in the Kara Sea Sediments

104 Kovalevskii A, Kovalevskaya O \& Prokopchuk S:

Biogenic Minerals in Plants

105 Obst M, Dittrich M, Mavrocordatos D \& Wehrli B:

Calcite Formation by Picoplankton

106 Reynaud-Vaganay S, Ferrier-Pages C, Sambrotto R, Juillet-Leclerc A \& Gattuso J:

INV Effect of Feeding on the Carbon Isotopic Composition of the Zooxanthellate Coral Stylophora Pistillata

107 Sano Y, Terada K \& Park E:

Ion Microprobe Dating of Dinosaur Tooth: Implications for High-level Lead Exposure

108 Vasconcelos C, Bernasconi SM, Warthmann R \& McKenzie JA:

Temperature-dependent Oxygen Isotope Fractionation Factor for Dolomite: Constraints Based on Bacterial Culture Experiments

109 Vennemann TW, Eckert C \& Hubberten HW

Laser-based Oxygen Isotope Analysis of Biogenic Silica 


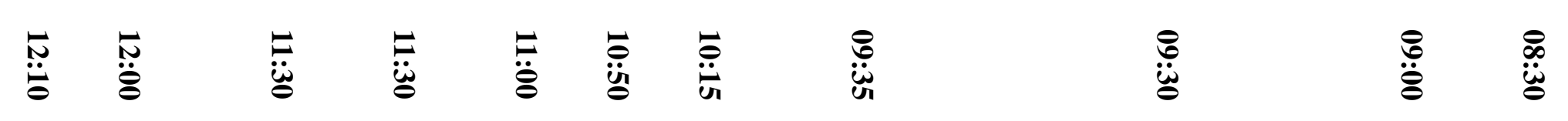
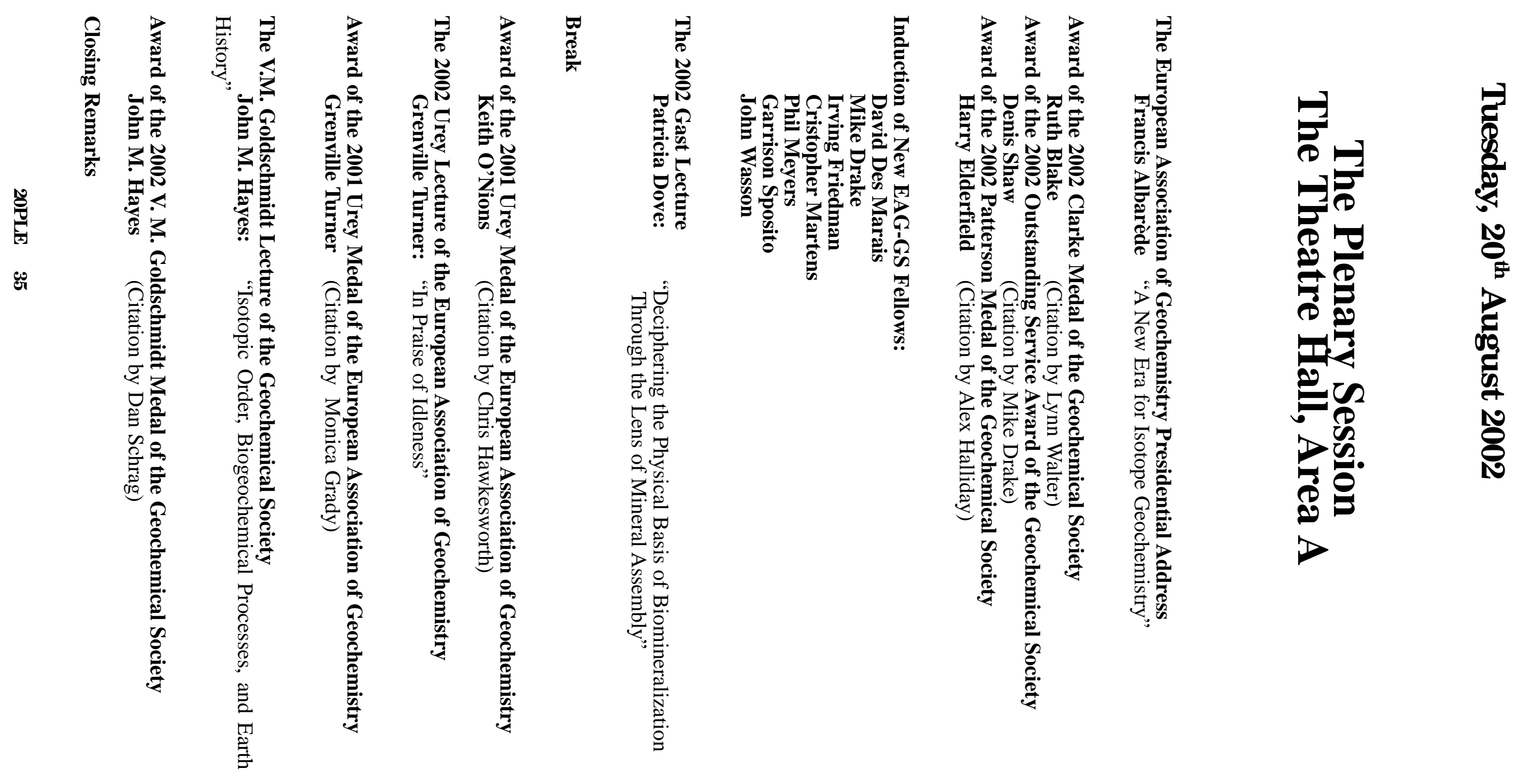


\section{Symposium G05}

\section{Igneous Geochemistry}

Convenors:

Alfons Berger, Alan Thompson \& Helen Williams

08:30 Tilton GR \& Bell K:

Mantle Pb Isostope Evolution Patterns

08:45 Hemond C, Dyment J, Maia M \& Gente P:

Central Indian Ridge and Reunion Hotspot in Rodrigues Area: Another Type of Hotspot - Ridge Interaction?

09:00 Gleeson M, Hunter A, McDermott F, Pearson G, Nowell G \& Fallick A: Geochemistry of Crustal Samples from the Atlantis Bank Platform, SWIR

09:15 Pushkarev Y, Kostoyanov A \& Orlova M:

Isotope Evidences of PGE Redistribution in the Mantle

09:30 Gaffney AM, Nelson BK \& Blichert-Toft J:

Chemical Complexity of the Kea Component Preserved in West Maui Lavas

09:45 Nelson BK, Blichert-Toft $J$ \& Albarède F:

$\mathrm{Nd}-\mathrm{Sr}-\mathrm{Hf}-\mathrm{Pb}$ Isotope Correlations in Lavas from Lanai, Hawaii

10:00 Waight T \& Baker J:

Chemical and Isotopic Investigations of low-Ti Depleted Continental Flood Basalts in East Greenland

10:15 Shaw J, Baker J, Menzies M, Thirlwall M \& Ibrahim K:

Petrogenesis of the Largest Intraplate Volcanic Field on the Arabian Plate (Jordan): Evidence for a Mixed Asthenosphere- Lithosphere Source

10:30 Teklay M, Hofmann AW, Brügmann GE \& Lassiter JC:

Chemical and Sr-Nd-Os Isotope Variations in Tholeiitic and Alkaline Flood Basalts from Eritrea: Evidence for Recycled Depleted Oceanic Crust in the Afar Plume

10:45 Stracke A, Zindler A, Salters VJ, McKenzie D \& Groenvold K:

The Dynamics of Melting beneath Theistareykir, Northern Iceland

11:00 Lowry D, Rollinson H \& Appel P:

Oxygen Isotopes of an Early Archaean Layered Ultramafic Body, West Greenland

11:15 Suzuki K, Shimizu H, Okamoto M, Hattori Y, Minami M \& Shimoda G:

Presence of Evolved Continental Crust in Archean Pilbara Craton, Western Australia: Evidence from Re-Os Isotopic Systematics of 3.4 Gyr Cherts

11:30 Shang CK, Siebel W, Satir M, Nsifa EN, Taubald H \& Chen F:

Geochemical and Geochronological Investigations of TTG Rocks from the Ntem Complex, Congo Craton and Implications for Post Magmatic Evolution

11:45 Conceicão RV, Rosa MdL, Conceição H \& Nardi LV:

Early Proterozoic Alkaline Magmatism in the Northeastern Brazil as an Evidence of Archean and Early Proterozoic Heterogeneous Mantle

12:00 Pla Cid J, Conceição RV, Nardi LV \& Stable L:

Late Proterozoic Alkaline Magmatism in the South Brazil as an Evidence of Mantle Heterogeneity

12:15 Delpech G, Grégoire M, Cottin J, O'Reilly SY, Michon G \& Moine BN:

$\mathrm{Na}-\mathrm{CO}_{2}$ Rich Metasomatism beneath the Kerguelen Oceanic Plateau (South Indian Ocean)

(Symposium G05 Continued in Session 21pm on Page 41)
Symposium G08

\section{Room C/S1}

Geochemistry of the Earth, Planets and Meteorites

Convenors:

Der-Chuen Lee \& Ingo Leya

08:30 Kounaves SP \& Hecht MH:

Geochemical Analysis on Mars

08:45 Musselwhite D \& Jones J:

Mineral/melt Partitioning of Sm, Eu and Gd: Implications for the Redox State of the Martian Mantle

09:00 Baker L, Franchi I, Wright I \& Pillinger C:

The Oxygen Isotopic Composition of Water Extracted from CV Carbonaceous Chondrites

09:15 Wang P, Rumble D \& McCoy TJ:

Oxygen Isotopic Composition of IVA Iron Meteorites and its Implications

09:30 Jagoutz E, Jotter R, Kubny A, Varela ME, Zartman R \& Kurat G: $\mathrm{Pb}-\mathrm{U}-\mathrm{Th}$ Isotopic Evolution of the D Orbigny Angrite

09:45 Ushikubo T, Hirai $K \&$ Hiyagon $H$ :

$\mathrm{Mg}$ Isotopic Compositions of W-L and Accretionary Rims of CAIs

10:00 Toppani A \& Libourel G:

New Constrains on Atmospheric Entry Conditions of Micrometeorites

10:15 Crozaz G, Floss C \& Wadhwa M:

Chemical Alteration of Hot and Cold Desert Meteorites

10:30 Sharp TG \& El Goresy A:

High-pressure Mineral Assemblages in Shocked Chondritic Meteorites: A Window to Constituents in Earth's Transition Zone and Lower Mantle

10:45 Nauret F, Abouchami W, Galer S, Hemond C \& Hofmann A:

$\mathrm{Sr}-\mathrm{Pb}$ Isotopic Evidence for Plume-ridge Interaction along the Central Indian Ridge

11:00 Schmitz MD, Vervoort JD, Bowring SA \& Patchett PJ:

Decoupling of the Lu-Hf and Sm-Nd Isotopic Systems in Granulitic Lower Crust beneath Southern Africa

11:15 White WM \& Paul D:

Constraints on ${ }^{232} \mathrm{Th} /{ }^{238} \mathrm{U}$ in the Crust from $\mathrm{Pb}$ Isotopes and Heat Flow

11:30 Ntaflos T, richter W \& Akinin $S$ :

LAM-ICP-MS and Whole-rock Investigations on Mantle Xenoliths from Chukotka, NE-Siberia

11:45 Coburn PM, Raiswell R, Bottrell S \& Newton R:

High-resolution Sulphur Isotopic Analysis, using Laser Ablation Techniques, on Pyritised Fossils from the Hunsrück Slate, Western Germany

12:00 Mullane E, Herrington RJ, Russell SS, Gounelle M, Weiss D \& Coles B: Iron Isotope Fractionation in an Archaean BIF Sample Suite

(Symposium G08 Continued in Session 21pm on Page 42) 


\section{Symposium S08}

\section{Komatiites}

\section{Convenors:}

\section{Nicholas Arndt, Janne Blichert-Toft \& Tim Grove}

08:30 Thordarson $\mathbf{T} \&$ Hill $R$ :

Endogenous Growth: Its Role in the Formation of Internal Pathways and the Emplacement of Mafic Flow Fields

08:45 Cas R, Beresford S, Rosengren N \& Trofimovs J:

INV Did Komatiites Behave Differently from Normal Lavas?

09:00 Barnes S, Hill R, Thordarson T, Dowling S \& Mattox T:

INV Bimodal Komatiite-dacite Volcanism in the Black Swan Area, Norseman-Wiluna Greenstone Belt, Australia

\section{9:15 Dann J:}

INV Inflation of Komatiite Lava Flows and the Origin of Spinifex Textures

09:30 Grove T, Parman S, Nuka P, de Wit M \& Dann J:

INV Influence of $\mathrm{H}_{2} \mathrm{O}$ on the Development of Spinifex Textures in Komatiite

09:45 Faure F, Arndt N \& Libourel G:

INV Crystallisation of Plate Spinifex Texture at $1 \mathrm{Atm}$. Pressure in a Thermal Gradient

10:00 Stone WE \& Deloule $E$ :

Hydromagmatic Amphibole in high-Mg Rocks of the Abitibi Greenstone Belt, Canada: Evidence for Archaean Wet Ultramafic Magmas

ฯ 10:15 Shimizu K, Nakamura E, Maruyama S \& Kobayashi K:

INV The Evolution of the Belingwe Greenstone Belt, Zimbabwe

10:30 Danyushevsky LV, Gee MAM, Nisbet EG \& Cheadle MJ:

INV Olivine-hosted Melt Inclusions in Belingwe Komatites: Implications for Cooling 10:45 Wilson A:

INV Early Archaean Highly-depleted Ultramafic Boninitic Lavas in the Southern Kaapvaal Craton, South Africa

11:00 Shirey SB, Wilson AH \& Carlson RW:

INV Re-Os Systematics of 3.3 Ga Nondweni-Commondale Komatiites, Kaapvaal Craton, South Africa

11:15 Stevenson RK, Bizzarro M, Simonetti A \& Gariépy C

Hf Isotope Composition of $3 \mathrm{Ga}$ Komatiites from Ontario, Canada

11:30 Williams DA:

Galileo Spacecraft Observations of Active Ultramafic Eruptions on Jupiter's Moon

(Symposium S08 Continued in Session 21pm on Page 43)
Symposium S18

Room C/S2

Properties of Geological Fluids and Solutes From Experiment to Simulation

\section{Convenors:}

Terry Seward \& Craig Manning

08:30 Wood RH, Liu W \& Doren DJ:

KEY Recent Progress in Predicting Free Energy of Aqueous Solutes at High Temperatures

09:00 Blencoe J:

Empirical Equations for Representing Vapor-liquid Equilibria in the $\mathrm{CO}_{2}-\mathrm{H}_{2} \mathrm{O}$ System at $110-350^{\circ} \mathrm{C}$

09:15 Diamond LW \& Krüger Y:

P-V-T-X Properties of Two $\mathrm{H}_{2} \mathrm{O}-\mathrm{CO}_{2}-\mathrm{NaCl}$ Mixtures up to $850^{\circ} \mathrm{C}$ and $500 \mathrm{MPa}$ Synthetic Fluid Inclusion Study

09:30 Haefner A \& Aranovich LY:

$\mathrm{H}_{2} \mathrm{O}$ Activity in $\mathrm{H}_{2} \mathrm{O}-\mathrm{N}_{2}$ Fluids at High Pressure and Temperature Measured by the Displacement of the Brucite-Periclase Equilibrium

09:45 Driesner T \& Heinrich CA:

Revised Critical Curve for the System $\mathrm{H}_{2} \mathrm{O}-\mathrm{NaCl}$

10:00 Lvov S, Zhou X, Fedkin M, Zhou Z, Kathuria A \& Barnes H:

Advanced Electrochemical Studies of Hydrothermal Systems

10:15 Dubois M, Monnin C, Papainocomou N \& Simonin J:

Thermodynamic Modelling of Lithium-bearing Aqueous Solutions

10:30 Martinez I, Sanchez Valle C, Daniel I, Philippot P, Reynard B \& Simionovici A: Experimental Study of Carbonate Aqueous Solutions at High Pressure and High Temperature

10:45 Newton R \& Manning C:

Activity Coefficient and Polymerization of Aqueous Silica Based on High-PT Solubility Measurements

11:00 Mayanovic RA, Jayanetti S, Anderson AJ, Bassett WA \& Chou I:

The Structure of $\mathrm{Yb}^{3+}$ and $\mathrm{Y}^{3+}$ Aquo ion and Chloro Complexes in Hydrothermal Solutions

11:15 Suleimenov O \& Seward T:

Grand Canonical Monte Carlo Simulations of High T-p Binary $\mathrm{H}_{2}-\mathrm{H}_{2} \mathrm{O}$ Fluids

11:30 Schmidt C \& Rickers K:

In-situ Determination of Mineral Solubilities in Fluids using a Diamond-anvil Cell and SR-XRF

11:45 Labotka T, Cole D, Fayek M \& Riciputi L:

Coupled Cation and Oxygen Exchange between Alkali Feldspar and Aqueous Chloride Solution

(Symposium S18 Continued in Session 21pm on Page 43) 


\section{Symposium S21}

\section{Erosion Factory I}

\section{Convenors:}

Nathalie Vigier \& Ken Farley

08:30 White A, Stonestrom D \& Schulz M:

Hydrologic and Thermodynamic Controls on Chemical Weathering

08:45 Hodson M:

The Influence of Amorphous Fe-rich Surface Coatings on the Dissolution of Anorthite at $\mathrm{pH} 2.6$

09:00 Chadwick O:

Control of Leaching Intensity on Weathering and Non-linear Changes in Soil Chemistry

09:15 Gaillardet J, Millot R \& Dupre B:

Chemical Weathering Rates in the Subarctics: The Example of the Mackenzie River System

09:30 Bourdon B, Vigier $N$ \& Allègre $C$ :

INV Models for Chemical Weathering Based on U-series Measured in Rivers

09:45 Vigier N, Burton K, Gislason S, Rogers N, Schaefer B \& James R.

Constraints on Basalt Erosion from Li Isotopes and U-series Nuclides Measured in Iceland Rivers

10:00 Reynolds B \& Wasserburg G:

Groundwater Weathering Rates from U- and Th- Series Nuclides

10:15 Matisoff G \& Whiting P:

Use of ${ }^{7} \mathrm{Be}$ as a Tracer of Sediment Erosion, Transport and Fate

KEY Spatially-averaged Erosion Rates from Cosmogenic Nuclides in Sediments: Ten Years Later

11:00 Bierman P, Nichols K, Clapp E, Matmon A, Caffee M \& Finkle R:

INV Tracking Landscape-scale Sediment Generation and Transport using in situ Produced ${ }^{10} \mathrm{Be}$ and ${ }^{26} \mathrm{Al}$

11:15 Gosse J \& Willenbring J:

Glacier Erosion Factory: Using ${ }^{26} \mathrm{Al} /{ }^{10} \mathrm{Be}$, Soils, and Geomorphology to Study Relief Development

\section{1:30 Heimsath AM:}

INV Simple Hillslope Erosion Narrated by Complex Methods

11:45 Schaller M, von Blanckenburg F, Hovius N \& Kubik P:

Paleo-erosion Rate Record in a 1.6 Ma Terrace Sequence of the Meuse River
Symposium S25

Room B/Fo

\section{Phanerozoic History of Greenhouse Gases}

Convenors:

Jerry Dickens, Mark Pagani \& David Beerling

08:30 Royer D:

INV A Critical Review of $\mathrm{CO}_{2}$ Proxies and Models

08:45 Berner RA:

KEY The Rise of Trees and their Effects on Paleozoic Atmospheric $\mathrm{CO}_{2}$ and $\mathrm{O}_{2}$

09:15 Kuhn T, Ostertag-Henning C, Joachimski M \& Freeman KH:

INV Evolution of the Photosynthetic Carbon Isotope Fractionation (ep) during the Late Paleozoic

09:30 Arens NC \& Jahren AH:

INV Reconstructing Greenhouse-gas History from the Plant Fossil Record: Examples from the Cretaceous

09:45 Brunner B, Wissler L, Bernasconi S, Weissert H \& D'Argenio B: Imbalances in the Sulfur Cycle: Important Players in the Carbon-system?

10:00 Pagani M, Zachos J \& Freeman K:

Eocene/Oligocene Alkenone-based $\mathrm{CO}_{2}$ Estimates

10:15 Kuerschner W, Kvacek Z \& Kump LR:

INV Tectonics, Weathering, Atmospheric $\mathrm{CO}_{2}$ and $\mathrm{C}$ Burial during the Mid-Miocene Climate Change

10:30 Pearson $\mathbf{P}$ \& Palmer M:

INV The Boron Isotope Approach to paleo- $\mathrm{pCO}_{2}$ Estimation

10:45 François LM, Gaillardet $\mathbf{J}$ \& Goddéris $Y$ :

INV Modelling the Cenozoic Evolution of Atmospheric $\mathrm{CO}_{2}$

11:00 Schrag D:

Control of Atmospheric $\mathrm{CO}_{2}$ and Climate Through Earth History

11:15 Kerrick D:

INV Magmatic $\mathrm{CO}_{2}$ Degassing and Global Paleoatmospheric $\mathrm{CO}_{2}$ Contents

11:30 Dickens G:

EPSL Frontiers Lecture: The Phanerozoic Carbon Cycle with a Gas Hydrate Capacitor

11:45 Kump L:

KEY $\mathrm{Is}_{\mathrm{CO}_{2}}$ the Phanerozoic Climate Driver? 


\section{Symposium S35}

Molecular Tools for the Identification of Important Geomicrobial Organisms

\section{Convenors:}

Dianne Newman \& Antje Boetius

08:30 Schouten S, Hopmans E, Schefuss E, Wuchter C \& Sinninghe Damste JS:

$K E Y \quad$ Geochemical and Environmental Importance of Marine Archaea

09:00 Nadalig T, Caprais JC, Loesekann T, Cambon-Bonavita M, Knittel K \& OluLeroy K:

Structure and Diversity of Microbial Communities at Two Methane Seep Sites (Gulf of Guinea)

09:15 Elvert M, Niemann H, Boetius A, Treude T \& Knittel K:

Lipid Biomarkers as a Tool for the Analysis of Anaerobic Methanotrophy in Marine Environments

09:30 Zhang C, Sassen R \& Lanoil B:

Carbon Cycling in the Gulf of Mexico Gas Hydrate Systems: A Review

09:45 Orphan V, House C, Hinrichs K, McKeegan K \& DeLong E:

INV Direct Phylogenetic and Isotopic Evidence for Multiple Groups of Archaea Involved in the Anaerobic Oxidation of Methane

10:00 Michaelis W, Seifert R, Nauhaus K, Treude T, Blumenberg M \& Knittel K:

INV Molecular Evidence for Microorganisms in Recent and Ancient Methane-related

10:30 Summons RE, Embaye T, Jahnke L \& Baumgartner M:

New Ether Lipid Biomarkers from a Thermophilic Methanogen

10:45 Benzerara K, Chapon V, Heulin T, Guyot F, Menguy N \& Skouri F:

Geomicrobiology of Carbonate Precipitations at the Surface of Pyroxenes in an Aridic Soil

11:00 Mauclaire L, Meister P, Zepp K, Vasconcelos C \& McKenzie JA:

Molecular Approach to Study Microbial Communities Involved in Modern Dolomite Formation

11:15 Simons D, Kenig F, Crich D \& Schroder-Adams C:

Significance of Novel Branched Alkanes with Quaternary Carbon Centers in Black Shales

11:30 Lee A \& Newman D:

Molecular Analyses of Mixed-species Biofilms on Carbon Steel

11:45 MacGregor BJ, Brüchert V, Fleischer S \& Amann R:

RNA as a Biomarker: Isolation of Small-subunit Ribosomal RNA for Stable Isotopic Characterization

12:00 Pearson A, Sessions AL, Delong EF \& Hayes JM:

INV Carbon Isotopic Analysis of Selected Nucleic Acids from Environmental Samples

12:15 Coates J \& O'Connor S:

INV A Universal Immuno-probe for (per)chlorate-reducing Bacteria

(Symposium S35 Continued in Session 21pm on Page 44)
Symposium S37

Room B/Ja

Colloids: Their Nature, Reactivity, and Role in the Transport of Pollutants

Convenors:

Gordon Brown \& Daniel Grolimund

08:30 Zachara J, Flury M \& Harsh J:

KEY Colloid Facilitated Migration of Radioelements - Mechanisms, Significance, and Needed Conditions

09:00 Buseck P \& Schwartz S:

INV Aerosols - The Colloids of the Atmosphere

09:15 Ingri J, Larsson J, Nordling S, Gustafsson Ö, Rönnegård J \& Andersson P: Biogeochemistry of Trace Metals during a Coastal Bloom in the Baltic Sea

09:30 Citeau L, Lamy I, van Oort F \& Elsass F:

Role of Colloids in the Metal Mobilisation in Soils: A Field Study

09:45 Grolimund D, Barmettler K \& Borkovec M:

INV Colloid-Facilitated Transport of Pollutants: Phenomena and Modeling

10:30 Navrotsky A:

INV Direct Calorimetric Measurements of Surface Energies and Phase Stability of Nanophase Oxides

10:45 Perigault JG \& Leckie JO:

INV Surface Complexation Modeling for the Description of Solution Chemistry, Adsorption, and Colloidal Aggregation

11:00 Heidmann I, Christl I \& Kretzschmar R:

Metal Sorption and Aggregation in Kaolinite-Fulvic Acid Dispersions

11:15 Icopini G, Brantley S \& Heaney P:

Kinetics of Silica Nanocolloid Formation from Supersaturated Solutions

11:30 Shaw S, Warner JA, Benning LG \& Brown Jr. GE:

INV SAXS/WAXS Studies of the Precipitation and Crystallisation of Iron and Aluminium (Oxy)hydroxides

11:45 Amor K \& Benning LG:

The Crystallisation of Colloidal As-S Phases: An in situ X-ray Diffraction Study

(Symposium S37 Continued in Session 21pm on Page 45) 


\section{Symposium S40}

Noble Gases in Geochemistry and Cosmochemistry

\section{Convenors:}

Don Porcelli, Chris Ballentine \& Rainer Wieler

08:30 Owen T:

KEY Noble Gases in Planetary Atmospheres

09:00 Trieloff M:

INV Primordial Noble Gases in the Earth: Remnants of Accreted Planetesimals or a Solar Protoatmosphere?

09:15 Ozima M, Miura YN \& Podosek FA:

INV Revisiting I-Xe Systematics, An Early Solar System Chronometer

09:30 Hohenberg CM, Pravdivtseva OV \& Meshik APM:

I-Xe Ages and Trapped Xe Compositions

09:45 Pravdivtseva O, Amelin Y, Hohenberg CM \& Meshik AP:

$\mathrm{I}-\mathrm{Xe}$ and $\mathrm{Pb}-\mathrm{Pb}$ Ages of Richardton Chondrules

10:00 Ebisawa N, Okazaki R, Nagao K \& Yamaguchi A:

Halogen-derived Noble Gases in the Allende Meteorite: A Laser Microscope Study

10:15 Vogel N, Baur H, Bischoff A \& Wieler R:

Noble Gases in Chondrules and Metal-sulfide Rims of Primitive Chondrites - Clues on Chondrule Formation

10:30 Busemann $H$, Baur H \& Wieler R:

Noble Gas Characteristics of the E Chondrite St. Mark's

10:45 Verchovsky A, Gilmour J, Halland G \& Wright I:

Search for Q: Single Grain Xe Isotope Analyses of Graphitic Residue from Yilmia (EL6)

11:00 Schwenzer SP, Mohapatra RK \& Ott U:

Nitrogen and Noble Gases in Caliche from the Martian Meteorite SaU 008

11:15 Nagao K \& Okazaki R:

Noble Gases of Antarctic Lunar Meteorite Yamato981031

(Symposium S40 Continued in Session 21pm on Page 45)

\section{Symposium S43}

\section{Room A/St}

\section{The Isotope Geochemistry of Hydrogen}

Convenors:

John Eiler \& Francois Robert

08:30 Jouzel J:

KEY Deuterium in the Terrestrial Water Cycle: Present-day Distribution and Paleoclimatic Applications

09:00 Rahn T, Eiler J, McCarthy M, Boering K, Atlas E \& Schauffler S:

The Deuterium Anomaly in Stratospheric Molecular Hydrogen

09:15 Sessions A, Schimmelmann A, Summons R, Boreham C, Logan G \& Hope J: Hydrogen Isotopic Compositions of Petroleum Hydrocarbons

09:30 Deloule E:

Measuring D/H Ratio of Femtograms of Hydrogen by Ion Microprobe: Limits and Applications

09:45 Hauri E:

$\mathrm{D} / \mathrm{H}$ and $\mathrm{H}_{2} \mathrm{O}$ in Mantle-Derived Basaltic Melt Inclusions

10:00 Boctor N, Alexander C, Wang J \& Hauri E:

$\mathrm{H}$ Isotope Signatures of Minerals, Melt Inclusions, and Impact Glasses in SNC Meteorites

10:15 Robert F \& Deloule E:

Using the D/H Ratio to Trace the Terrestrial Water Contamination in Chondritic Meteorites

10:30 Eiler I \& Kitchen N:

Hydrogen-isotope Geochemistry of the CM Chondrites 


\section{Symposium G03}

\section{Climate Change}

\section{Convenors:}

\section{Room B/Fo}

Miriam Andres \& Christian Schlïchter

13:30 Scheffler K, Hoernes S \& Schwark L:

Climate Changes during and after Palaeozoic Glaciation Phases in SW-Gondwana Recorded by Multi Proxygeochemical Investigations

13:45 Starinsky A, Stein M, Almogi-Labin A, Goldstein SL \& Hemleben C:

Strontium Isotopes in the Red Sea-Gulf of Aden during the Past 530 Kyr: The Role

of Hydrothermal and "Erosional" Components during Glacial Interglacial Cycles

14:00 Almogi-Labin A, Bar-Matthews M, Paterne M, Ayalon A \& Schilman B:

The Relationship between the Marine and the Terrestrial (Speleothems) Climatic Record during the Last $80 \mathrm{ka}$ in the Eastern Mediterranean

14:15 Wada H, Nagayama M, Miura H \& Kashima K:

Holocene Climatic Change Record in the Sediment Core from Lake Richardson, East Antarctica

14:30 McDermott F:

Solar Forcing of Holocene Climate; Where are the Amplifiers?

14:45 Shapley MD, Ito E \& Donovan J:

Paleohydrology of Lakes from Isotopic and Elemental Chemistry

$ث$ 15:00 Hsueh-Wen Y:

Abrupt Climate Changes in Taiwan

15:15 McGarry S, Bar-Matthews M, Matthews A \& Ayalon A:

Palaeohydrology in the Eastern Mediterranean from Speleothem Fluid Inclusion $\mathrm{D} / \mathrm{H}$ Analyses

15:30 Zimmerman S, Hemming S, Hemming NG \& Tomascak P:

Late Pleistocene Variations of Lake Level and Glacial Activity at Mono Lake, CA, USA

15:45 Mattey D, Grimes S, Hooker J \& Collinson M:

Testing Concordance of Oxygen Isotope Palaeotemperatures Obtained from Associated Rodent Tooth Phosphate and Freshwater Carbonate: An Eocene Example from the Hampshire Basin

\section{Symposium G05}

\section{Igneous Geochemistry}

Convenors:

Alfons Berger, Alan Thompson \& Helen Williams

13:30 Johnson EA \& Rossman GR:

The Thermal Stability of Hydrogen in Feldspars

13:45 Deines $P$ :

On the Carbon Isotope Fractionation between Silicate Melts and Gaseous $\mathrm{CO}_{2}$

14:00 Kanzaki M \& Xue X:

NMR Evidence for a New Water Dissolution Mechanism in Alkaline Earth Silicate Melts

14:15 Vrublevsky V, Gertner I \& Voitenko D:

Fractionation of Oxygen Isotopes between Minerals from Alkaline Basic Rocks of Kuznetsky Alatau Ridge (South Siberia)

14:30 Notsu K, Mori T \& Sumino H:

High $\mathrm{HCl}$ Flux from Miyakejima Volcano, Japan

14:45 Chazot G, Bertrand H, Mergoil J \& Sheppard S:

Immiscible Dolomitic Carbonatitic and Trachytic Magmas and the First Occurrence of Carbonatites in the French Massif Central

15:00 Monjoie P, Bussy F, Schaltegger U, Lapierre H \& Pfeifer H:

Contrasting Mantle Sources for the Permian Mafic Magmatism in the Alps: Insight from the Mont-Collon Gabbro (Dent-Blanche Nappe, Western Alps)

15:15 Bellomo S, Del Carlo P, D'Alessandro W, Coltelli M \& Parello F:

Magmatic Gas Scavenging Through Ashes: Mt. Etna July-August 2001 Eruption

15:30 Simon J \& Reid M:

The Bishop Tuff: A Direct Descendant of Glass Mountain Rhyolite? Probably Not

15:45 Andersen T \& Griffin W:

The Mesoproterozoic Continental Margin of the Baltic Shield: Geochemical Evidence for a Cordillera-type Setting

16:00 Zhao Z, Xiong X \& Bai Z:

The Adakite-like Dacites and Potassic Volcanic Rocks in Chinese Western Tianshan

16:15 Tejada ML \& Castillo P:

In Search of a Common Ground: Geochemical Study of Ancient Oceanic Crust in Eastern Luzon, Philippines 


\section{Symposium G08}

Geochemistry of the Earth, Planets and Meteorites

\section{Convenors:}

Der-Chuen Lee \& Ingo Leya

13:30 Beyer EE, Griffin W, Pearson N \& O'Reilly S:

Archean Mantle Hidden in Proterozoic Crust in SW Norway

13:45 Peltonen $P, O^{\prime} B r i e n ~ H \&$ Kukkonen I:

Chemical Composition and Thermal State of the Continental Mantle in Central Fennoscandia

14:00 Yao L \& Gao Z:

Abnomal Enrichment of Selenium in Yutangba Carbonaceous Cherts, Southeast Enshi, Hubei Province, China

14:15 Ye L, Liu Y, Li C \& Liu J:

Some Clue of Coupling Relationship between Dongchuan Copper and the Breakup of Rodinia

14:30 Wang J, Li Z \& Li C:

Origin of Ore-forming Fluids of MVT Pb-Zn Deposits in Kangdian Area, China

14:45 Shayestehfar MR:

Ore Geology, and Geochemistry of Soughan Ultramafic Mafic Complex, Esfandagheh Southeast Iran

15:00 Dangic A:

Geochemical Model of Early Earth`s Surface Systems, Based on Extended Conception of Ionic Potential

15:15 Gao Z \& Yao L:

Study on the Mechanism of Metallogenesis of the Dispersed Elements $\mathrm{Ge}, \mathrm{Se}, \mathrm{Cd}$ and $\mathrm{Tl}$

15:30 Ozawa K \& Nagahara $\mathrm{H}$ :

Incongruent Evaporation of Olivine at Low Temperature

15:45 Shilobreeva S \& Kuzmin L:

Carbon Migration in Olivines Under Natural Irradiation: Experimental and Numerical Modelling

16:00 Fialips C, Righi D \& Potter KN:

Effect of Agricultural Activities on the Mineralogy of Soil Clays

16:15 Makarenko G:

Fe-Mg Silicate Strings on the Earth

\section{Symposium G10}

\section{Computational Geochemistry}

\section{Room A/St}

Convenor:

Thomas Driesner

13:30 Sahai N:

Kinetic Effects of $\mathrm{Mg}^{2+}$ on Heterogeneous Apatite Nucleation at Amorphous Silica Surfaces

13:45 Kerisit S, Parker S \& Harding J:

Atomistic Simulation of the Structure and Reactivity of Calcite Surfaces

14:00 Cooke DJ \& Parker SC:

Segregation of Isovalent Impurities to the $\{00.1\}$ and $\{01.2\}$ Surfaces of Hematite $\left(\alpha-\mathrm{Fe}_{2} \mathrm{O}_{3}\right)$ using Atomistic Simulations

14:15 Zaidan O, Greathouse J \& Pabalan R:

Computer Simulation of Uranyl Adsorption on Montmorillonite Clay

14:30 Kulik DA:

Density Parameters in Thermodynamic Surface Complexation Models

14:45 Sommacal S, Sambridge M \& O'Neill H:

Computational Petrology and Pyroxene Thermodynamics

15:00 Shosa J:

Simplified Procedures for the Estimation of the Revised-HKF Equation of State Coefficients: Concerns and Insights 


\section{Symposium S08}

Room C/A2

\section{Komatiites}

\section{Convenors:}

\section{Nicholas Arndt, Janne Blichert-Toft \& Tim Grove}

13:30 Cheadle M \& Sparks D:

$K E Y \quad$ Can Komatiites be "Dry" Plume-type Magmas?

14:00 Parman S, Grove T, de Wit M \& Dann J:

KEY EPSL Frontiers Lecture: Komatiites: The Subduction Perspective

14:30 Walker R:

INV Evolution of Osmium Isotopes In Komatiite Sources

14:45 Hanski E, Walker RJ, Polyakov GV, Glotov A, Balykin P \& Hoa TT:

INV Permian-Triassic Komatiites and their Os Isotopic Characteristics in Northern Vietnam

15:00 Puchtel IS, Humayun M, Campbell AJ, Sproule RA \& Lesher CM:

INV PGEs in Abitibi Komatiites

15:15 Jenner G, Shirey S, Hyde D, Elkins L, Kjarsgaard B \& Kerswill J

$I N V$ Late Archean Komatiites and BIFs, Woodburn Lake Group, Churchill Province, Nunavut

15:30 Frei R \& Karstbjerg Jensen B

Re-Os, Sm-Nd Isotope- and REE Systematics on Komatiites and Pillow Basalts from the Earth's Oldest Oceanic Crustal Fragments (Isua Supracrustal Belt, W Greenland)

15:45 Arndt N:

INV Komatiites, Kimberlites and Boninites
Symposium S18

Properties of Geological Fluids and Solutes From Experiment to Simulation

Convenors:

Terry Seward \& Craig Manning

13:30 Sherman DM:

KEY Coordination Chemistry of Metals in Crustal Fluids: Theory and Experiment

14:00 Zakaznova-Iakovleva V \& Seward T:

Spectrophotometric Study of Thioarsenite Speciation in High Temperature Aqueous Solutions

14:15 Tossell JA:

Calculation of the Energetics for the Oxidation of Sb(III) Sulfides by Elemental S and Polysulfides in Aqueous Solution

14:30 Black J, Spiccia L \& McPhail DB:

Copper Complexes in Thiosulfate-ammonia-chloride Brines

14:45 Stefansson A \& Seward T:

The Hydrolysis of Gold(I) and the Formation of Chlorogold(I) Complexes in Hydrothermal Solutions to $600{ }^{\circ} \mathrm{C}$ and $2 \mathrm{Kbar}$

15:00 Baranova N, Osadchii E, Gurevich V, Tagirov B, Zotov A \& Schott J:

Experimental Determination of the Standard Thermodynamic Properties of Solid Phases in the Au-Ag-S System

15:15 Muller M \& Mountain B:

$\mathrm{Tl}$ and $\mathrm{Au}$ in Low T Hydrothermal Fluids: An Experimental Study

15:30 Tagirov B, Salvi S, Baranova N, Schott J \& Harrichoury J:

Experimental Study of $\mathrm{Au}(\mathrm{HS})_{2}$ - Stability in Hydrothermal Fluids using Minera Buffers

15:45 Mroczek E \& Christenson B

Oxidation Rates of $\mathrm{Hg} 0$ in Geothermal Fluids 


\section{Symposium S21}

\section{Erosion Factory I}

Convenors:

Nathalie Vigier \& Ken Farley

13:30 Singh SK \& France-Lanord C

Erosion Distribution in the Eastern Himalaya Traced by Sr-Nd Isotopic Compositions of River Sediments

13:45 Brown R, Cockburn H, Kohn B, Belton D, Fink D \& Gleadow A:

Combining Low Temperature Apatite Thermochronology and Cosmogenic Isotope Analysis in Quantitative Landscape Evolution Studies

14:00 Hewawasam T, Von Blanckenburg F \& Kubik P: Ancient Landscapes in Wet Tropical Highlands, Sri Lanka

14:15 Fitzgerald P, Baldwin S, Farley K, Hedges L, O'Sullivan P \& Webb L:

Constraining Landscape Evolution of the West Antarctic Rift Flank of Southern Victoria Land

14:30 Ehlers TA \& Farley K:

INV Apatite (U-Th)/He Signals of Transient Topography

14:45 Raab MJ, Brown RW \& Gallagher K:

Quantifying Denudation Rates with Vertical Relief Fission Track Profiles

15:00 Pik R, Marty B \& Carignan J:

Long-term Drainage Network Stability and Uplift of the Ethiopian Plateau Deduced from (U-Th)/He Thermochronometry

15:15 Barfod DN \& Stuart FM:

Cenozoic Denudation of Scotland from (U+Th)/He Apatite Thermochronology

15:30 Persano C, Stuart F \& Bishop P:

Low-T Thermochronology Constraints on the Development of the Australian Great Escarpment

15:45 Gleadow A, Kohn B, Brown R \& O'Sullivan P.

Contrasting Regional Denudation Patterns in Southeastern Australia from Apatite Fission-track Imaging
Symposium S35

Room B/Pi

Molecular Tools for the Identification of Important Geomicrobial Organisms

Convenors:

Dianne Newman \& Antje Boetius

13:30 Keller M, Zengler K, Toledo G, Elkins J, Mathur E \& Short J:

INV Microbiology: What is Next?

13:45 Morel FM:

INV Novel Metalloproteins in Marine Phytoplankton

14:00 Beja O:

KEY Light Driven Environmental Genomics

\section{Symposium S36}

Room B/Pi

Biogenic Substances and their Effect on Trace Metal Cycling and Mineral Weathering

\section{Convenors:}

Stephan Kraemer \& Javiera Cervini-Silva

14:30 Stone A \& Uchimiya M:

KEY Extracellular Redox Biochemicals: Design Constraints

15:00 Martin S \& Jun Y:

INV Microscopic Observations of Manganite Reductive Dissolution

15:15 Nico P, Benner S \& Fendorf $S$ :

INV Uranium Retention by Biogenic Magnetite

15:30 Kaiser E, Sulzberger B, Emmenegger L \& Sigg L

Effects of Biogenic Substances on the Light-induced Redox Cycling of Iron in Surface Waters

15:45 Brantley $S$ \& Liermann L:

INV Microbial Extraction of $\mathrm{Ni}, \mathrm{Mo}$, and Fe Micronutrients from Earth Materials 


\section{Symposium S37}

Colloids: Their Nature, Reactivity, and Role in the Transport of Pollutants

\section{Convenors:}

\section{Gordon Brown \& Daniel Grolimund}

13:30 Cummings $P$, Predota $M$ \& Chialvo A:

INV Molecular-based Study of the Electric Double Layer in Hydrothermal Systems

13:45 van Riemsdijk W \& Hiemstra $T$ :

INV Surface Chemistry of Reactive Mineral Colloids

14:00 Sverjensky D:

Standard States for the Equilibrium Constants of Surface Adsorption Reactions: Practical Implications

14:15 Benedetti MF, Ponthieu M, Hiemstra T \& van Riemsdijk W:

INV Modelling of Metal Ions Sorption to Various Oxy-hydroxides Colloids

14:30 Farges F, Benedetti M, Berrodier I \& Brown Jr GE:

INV Modelling the Sorption of Metal Cations on Metal Hydroxides: Experiment vs. Model

14:45 Peacock CL \& Sherman DM:

Vanadium (III, IV and V) Sorption onto Goethite $\alpha-\mathrm{FeOOH}$

15:00 Bazin D:

INV Solid State Concepts to Understand Catalysis using Nanoscale Metallic Particles

\& 15:15 Daehn R, Scheidegger AM, Manceau A, Baeyens B \& Bradbury M:

Surface Reactivity of Clay Nanoparticles as Studied by Polarized EXAFS

15:30 Casey B \& Phillips B:

INV Rates of Oxygen-Isotope Exchange in Al(III) Polyoxocations

15:45 Tossell JA:

Perturbing the Tridecameric $\mathrm{AlO}_{4} \mathrm{Al}_{12}(\mathrm{OH})_{24}\left(\mathrm{H}_{2} \mathrm{O}\right)_{12}{ }^{7+}$ Polycation: Effects of Substitution, Deprotonation, Dehydration and Adsorption of Arsenites and Arsenates

16:00 Fein JB, Yee $\mathbf{N} \&$ Boily J:

Low pH Protonation of Bacterial Cell Walls: New Data for Bacillus subtilis

16:15 Yee N \& Benning $L$.

In situ FTIR Study of Protonation Reactions at the Bacteria-water Interface

\section{Symposium S40}

Room A/Fm

Noble Gases in Geochemistry and Cosmochemistry

Convenors:

Don Porcelli, Chris Ballentine \& Rainer Wieler

13:30 Li Y, Song H \& Li J:

A Comparative Study of Helium Isotope For Manganese Nodules and their Surrounding Sediments

13:45 Sun Z \& Zhou W:

Isotopic Geochemistry of Hotsprings in South Jiangxi Province, China

14:00 Yang $T$ :

${ }^{3} \mathrm{He} /{ }^{4} \mathrm{He}$ Ratios of Fluid Samples in Taiwan

14:15 Zhou Z, Ballentine C, Kipfer R, Schoell M \& Thibodeaux S:

Noble Gas Tracing of Coalbed Methane Generation and Biomodification

14:30 Holocher J, Peeters F, Aeschbach-Hertig W, Hofer M \& Kipfer R:

Gas Exchange in Quasi-saturated Porous Media: Investigations on the Formation of Excess Air using Noble Gases

14:45 Aeschbach-Hertig W, Beyerle U \& Kipfer R:

Excess Air in Groundwater as a Proxy for Paleo-humidity

15:00 Winckler G \& Schlosser P:

INV Noble Gases in the Ocean - Recent Examples from the Modern and Paleocean

15:15 Lippmann J, Stute M, Torgersen T, Moser D, Hall J \& Onstott TC: Dating Ultra-deep Mine Waters with Noble Gases and ${ }^{36} \mathrm{Cl}$, Witwatersrand Basin, South Africa

15:30 Farley K, Shuster D, Burnett D \& Sisterson J:

Using Proton-induced ${ }^{3} \mathrm{He}$ to Study He Diffusion Kinetics and Rock Therma Histories

15:45 Stockli DF \& Farley KA

Apatite (U-Th)/He Multi Grain-size Analysis: A Thermal History Tool

16:00 Martens CS, Shay TJ, Mendlovitz HP, Menton MC, Moura JM \& Moraes OL: Radon-222 Determination of $\mathrm{CO}_{2}$ and Trace Gas Exchange Rates between Fores Canopies and the Troposphere in Brazilian Amazonia

(Symposium S40 Continued in Session 22am on Page 50) 


\section{Symposium G01}

\section{Geochronology}

\section{Convenors:}

Urs Schaltegger, Mike Cosca \& Jost Eikenberg

08:30 Tagami T, Murakami M, Hasebe N, Kamohara H \& Takemura K: Zircon Fission-track Thermochronology of the Nojima Fault System

08:45 Rahn M:

Preliminary Results from FT Dating of the Adula Nappe: Late Tilting or Not?

09:00 Baldwin SL, Batt GE \& Brandon M:

Thermochronology of the Foot Wall of the Central Segment of the Alpine Fault, South Island, New Zealand

09:15 Evans N, Wilson N, Cline J, McInnes B \& Byrne J:

Developments in Fluorite (U-Th)/He Thermochronology

09:30 Crowhurst PV, Farley KA, Ryan CG, Duddy I \& Blacklock KA:

Rutile as a Potential (U-Th)/He Thermochronometer

09:45 Travin A, Aschepkov I, Udin D \& Prostyakov K:

Laser and Stepwise-heating ${ }^{40} \mathrm{Ar} /{ }^{39} \mathrm{Ar}$ Dating of Kimberlite-like Rocks from Sayan Foothills and Peripheral Part of the Siberian Platform

10:00 Chen F, Guo J, Siebel W \& Satir M:

Provenance of Low-grade Metamorphic Terrains of the Dabie UHP Collisional Zone, Central China

\& 10:15 Reischmann T \& Kostopoulos D:

Timing of UHPM in Metasediments from the Rhodope Massif, N Greece

10:30 Peressini G, Poller U, Todt W, Quick JE, Sinigoi S \& Sbisa' A:

Age of Magmatism in the Ivrea Zone, NW Italy: A Zircon Study to Test the Emplacement Model

10:45 Corfu F, Krogh Ravna E \& Kullerud K:

A Late Ordovician U-Pb Age for HP Metamorphism of the Tromsdalstind Eclogite in the Uppermost Allochthon of the Scandinavian Caledonides

11:00 Liati A \& Gebauer D:

U-Pb SHRIMP-dating of Zircon Domains from Xenoliths of the Rio Grande Rift (Kilbourne Hole): Implications for the Timing of Mantle Events

11:15 Clechenko C, Valley J, Hamilton M, McLelland J \& Bickford M:

Direct U-Pb Dating of the Marcy Anorthosite, Adirondacks, NY, USA

11:30 Lapen TJ, Mahlen NJ, Johnson CM, Beard BL \& Baumgartner LP:

Lu-Hf Geochronology of UHP Metamorphism in the Zermatt-Saas Ophiolite, Lago di Cignana, Italy

11:45 Augustsson C \& Bahlburg H:

Sedimentary Sources Revealed by Nd Isotopes: The Late Palaeozoic of Southern Andean Patagonia

(Symposium G01 Continued in Session 22pm on Page 51)
Symposium S03

Room C/S1

Early Differentiation of Earth and Other Planets

Convenors:

Mini Wadhwa, Monica Grady, Kevin Zahnle

\& Kevin Righter

08:30 Jones J, Neal C \& Ely J:

KEY Highly Siderophile Elements and Planetary Accretion

09:00 Drake MJ:

Formation of the Earth

09:15 Palme H \& O'Neill H:

Meteorites and the Composition of the Earth

09:30 Javoy M:

The Early Evolution of the Earth: Core Formation, Mantle Differentiation and Volatile Evolution

09:45 Corgne A \& Wood BJ:

Constraints on Gross Mantle Differentiation from Perovskite-melt Partitioning of Trace Elements

10:00 Albarède F, Blichert-Toft J \& Boyet M:

KEY A Lu/Hf and Sm/Nd Perspective on the Early Differentiation of the Earth, Moon, Mars, and EPB

10:30 Mezger K, Münker C \& Scherer EE:

Lu-Hf Constraints on Early Lunar Differentiation

10:45 Schönbächler M, Lee D, Halliday AN, Rehkämper M, Hattendorf B \& Günther D:

${ }^{92} \mathrm{Nb}-{ }^{92} \mathrm{Zr}$ Chronometry and Early Lunar Evolution

11:00 Blichert-Toft J, Boyet $M$ \& Albarède $F$ :

${ }^{76} \mathrm{Lu}-{ }^{176} \mathrm{Hf},{ }^{147} \mathrm{Sm}-{ }^{143} \mathrm{Nd}$, and ${ }^{92} \mathrm{Zr}$ Isotope Systematics in Eucrites

11:15 Wiechert U, Halliday A, Palme H \& Rumbel III D:

Oxygen Isotopic Heterogeneity Among Eucrites

11:30 Holzheid A, Holzheid A \& Palme H:

The Formation of Meteoritic Basalts: Constraints from Metal-silicate Partition Coefficients

11:45 Hartmann WK:

Planetary Cratering Histories: Moon, Mars, and Questionable Cataclysm

12:00 Dikov YP, Gerasimov MV, Yakovlev OI \& Wlotzka F:

Impact-induced Early Differentiation of Terrestrial Planets

(Symposium S03 Continued in Session 22pm on Page 52) 


\section{Symposium S09}

\section{Core - Mantle Exchange}

\section{Convenors:}

Don Porcelli, Bernie Wood \& Rich Walker

08:30 Hillgren VJ:

INV Core-Mantle Interaction

08:45 O'Neill HSC \& Redfern SAT:

An Electrochemical Cell Across the Core-mantle Boundary

09:00 Wade J \& Wood BJ:

Heating the Core

09:15 Siebert J, Malavergne V, Guyot F, Hammouda T, Combes R \& Martinez I: Silicon, Sulphur and Carbon Behaviour during Core/mantle Segregation

09:30 Bodinier J, Kalfoun F, Godard M, Barsczus HG \& Sabaté P:

$\mathrm{Nb} / \mathrm{Ta}$ Geochemical Reservoirs

09:45 Jochum KP, Hofmann AW, Seufert M \& Stoll B: Niobium in Planetary Cores

10:00 Meibom A, Frei R, Chamberlain CP, Coleman RG, Hren MT \& Sleep NH:

Os Isotopes, Deep-rooted Mantle Plumes and the Timing of Inner Core Formation

10:15 Brandon A:

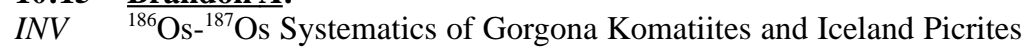

10:30 Collerson K, Schoenberg R \& Kamber B:

Unradiogenic W in Kimberlites: Direct Evidence for Core-Mantle Interaction

10:45 Kamber B, Schoenberg R \& Collerson K:

How Unradiogenic is $\mathrm{Pb}$ in the Core? No Limits to Core-mantle Exchange
Symposium S17

Room C/A2

Magma Chambers and Ore-forming Processes at the Magmatic - Hydrothermal Interface

Convenors:

Jim Webster \& Werner Halter

08:30 Holloway_J:

KEY Changes in Volatile Speciation during Magma Generation, Crystallization and Degassing

09:00 Nekvasil H, Lindsley D, Dondolini A, Horn J, Litvin V \& Rossier L:

INV The Role of Dissolved Water in the Compositional Evolution of Anorogenic Magmas

09:15 Stebbins J, Sandland T, Du L \& Kicenski T:

INV Structural Environments for Chloride and Fluoride Ions in Aluminosilicate Glasses: NMR Results

09:45 Veksler I, Badanina E \& Thomas R:

Experimental Evidence of the Role of Liquid Immiscibility in Evolution of Granitic Pegmatites and Li-F Granites

10:00 Dolejs D \& Baker DR:

Melting Equilibria of F-bearing Silicic Magmas: An Experimental Study

10:15 Schatz OJ, Dolejs D, Stix J, Williams-Jones AE \& Layne GD:

Boron Partitioning in the Haplogranite- $\mathrm{NaCl}-\mathrm{H}_{2} \mathrm{O}$ System at $800^{\circ} \mathrm{C}$ and $100 \mathrm{MPa}$

10:30 Webster J:

INV The Exsolution of Magmatic Brine

10:45 Kamenetsky V \& Naumov V:

Melt Immiscibility in Granite: A "Missing Link" in Magmatic-hydrothermal Transition

11:00 Métrich N, Bonnin-Mosbah M, Susini J, Menez B \& Galoisy L:

INV Presence of Sulphite $\left(\mathrm{S}^{\mathrm{IV}}\right)$ in Basaltic Magmas: Implications for Volcanic Sulphur Emissions

11:15 Wallace P:

INV Vapor Saturation in Felsic Magmas \& Vapor-Melt Partitioning of Sulfur

11:30 Bessonov D:

Mineral Forming Processes in the Modern Volcanic Areas (Kuril Islands) as the Indicator of Fluid Flow Conditions

11:45 Fiebig J, Caliro S \& Hunziker J:

Origin of Methane within a Subduction Related High-temperature Hydrothermal System and its Role in Risk Evaluation

(Symposium S17 Continued in Session 22pm on Page 53) 
Symposium S19

Room C/S2

Innovative Interpretations of Experimental and Field Geochemical Processes Using Reactive Transport Modeling

Convenors:

C. Steefel, C. Ayora \& P. Van Cappellen

08:30 Mader UK, Adler M, Steefel CI, Waber HN \& Traber D:

Core Infiltration Experiment and Modelling of Reactive Transport of high-pH Solution in Clay Stone

08:45 Soler J \& Mäder U:

The GTS-HPF Experiment: Reaction-induced Permeability Changes

09:00 do Nascimento Guimarães LJ, Gens A \& Olivella S:

Investigation of Damage Formation Around Wellbores using Reactive Transport Modeling

09:15 Fairchild IJ, Tuckwell GW, Baker A \& Tooth AF:

Combined Modelling of Hydrological and Hydrochemical Dripwater Data to Deduce Karstic Plumbing

09:30 Jamtveit B, Malthe-S' ${ }^{-}$renssen A, Kostenko O \& Flekkoy E:

Deformation Assisted Fluid Migration in Rocks

09:45 Kent D, Wilkie J, Curtis G \& Davis J:

Modeling the Influence of Variable $\mathrm{pH}$ on Zinc Contamination in a Quartz-sand Aquifer

10:00 Isenbeck-Schroeter M, Hoehn R, Stadler S, Jann S, Davis J \& Kent D:

Tracer Tests with Arsenic(III) and Arsenic (V) at the Cape Cod Site

10:15 Gwo JP, Mayes M \& Jardine P:

Reactive Transport in Fractured Saprolite: Determining Diffusive Mass Transfer and Surface Reaction Kinetics Parameters

10:45 Saaltink MW, Ayora C, Stuyfzand PJ \& Timmer H:

Calibration of a Reactive Transport Model to Interpret a Deep-well-recharge Field Experiment at Langerak (The Netherlands)

11:00 Mayer U \& Blowes D:

Constraining Reactive Transport Models using Mineralogical Data

11:15 Monnin C, Wheat G \& Mottl M:

The Influence of Basement Fluid Upwelling and Diagenetic Reactions on Mineral Stabilities in Oceanic Ridge Flank Sediments

11:30 Steefel CI, Rye RM, Sak PB \& Brantley SL:

Interpretation of Weathering Profiles from the Paleo-Proterozoic and Present using Reactive Transport Modeling

11:45 Gadish S, Matthews A \& Ilani S:

Low-temperature Reactive Transport of Fe-Mg-Si Bearing Solutions in Sedimentary Carbonate Host-rock

(Symposium S19 Continued in Session 22pm on Page 53)
Symposium S27

Room B/Fo

\section{Sources and Sinks of Aerosols and Dust}

\section{Convenors: $\quad$ Bruno Hamelin, Sidney Hemming \& Karen Kohfeld}

08:30 Kohfeld KE:

KEY The Role of Dust in Climate Cycle

09:00 Ridgwell A:

Does the Ocean Iron Cycle Destabilize the Glacial Climate System?

09:15 Tegen I, Harrison SP, Kohfeld KE, Engelstaedter S \& Werner M

Emission of Soil Dust Aerosol: Anthropogenic Contribution and Future Changes

09:30 Aubert D, Stille P \& Probst A:

Origin and Migration of Atmospheric REE in Soils and Surface Waters

09:45 Chauvel C, Dia A \& Bulourde M:

Eolian Dust Contribution to Soils on Mount Cameroon

10:00 Aleon J, Chaussidon M, Marty B, Schütz L \& Jaenicke R:

Oxygen Isotopic Composition of Single Aerosol Particles: A Study of Saharan Dus Sources

10:15 Moreno A, Cacho I, Canals M, Prins MA, Sánchez-Goñi MF \& Grimalt JO:

Saharan Dust Transport and High Latitude Glacial Climatic Variability at Millennia Time-scale

10:30 Abouchami W \& Zabel M:

The $\mathrm{Pb}$ Isotope Record of Terrigenous Input into the Tropical Atlantic

10:45 Bavon G, German CR, Burton KW \& Nesbitt RW:

The Role of Aeolian Dust in Scavenging Rare Earth Elements from the Ocean

11:00 Anderson R \& Fleisher $M$ :

Glacial-Interglacial Variability in the Accumulation of Lithogenic Material in Central Equatorial Pacific Sediments

11:15 Bory AJ, Biscaye PE \& Grousset FE:

Modern Seasonal Sources of east-Asian Dust to Greenland

11:30 Zhong.J, Hemming S \& Hanson G:

Evaluation of Ar-Ar Ages of Individual Mica Grains for Provenance Studies of Loess, Long Island, NY

11:45 Delmonte B, Basile-Doelsch I, Michard A, Petit JR, Maggi V \& RevelRolland M:

Sr-Nd Signature of Potential Source Areas for Dust in East Antartica: Preliminary Results 


\section{Symposium S31}

\section{Environmental Tracers for Groundwater Dating}

\section{Convenors:}

\section{Gisela Winckler \& Bernhard Lehmann}

08:30 Phillips F, Mills S \& Hogan J:

$K E Y \quad$ Salinization of the Rio Grande: Young Water, old Salts?

09:00 Hoehn E, Surbeck H, Salhi E \& von Gunten U:

Continuous Radon Measurement in Groundwater

09:15 Schlosser P, Stute M, Turrin B \& Plummer N:

INV Progress in tritium $/{ }^{3} \mathrm{He}$ Dating of Shallow Groundwater

09:30 Solomon K, Sheldon A \& Manning A:

INV Constraining Groundwater Flow in Fractured Aquifers using Environmental Tracers

09:45 Stute M, Simpson HJ, Chillrud SN, Law-Wai E \& Schlosser P:

INV Tracing Groundwater Transport Underneath a Landfill with $\mathrm{SF}_{6}, \mathrm{Br}$, and ${ }^{3} \mathrm{H} /{ }^{3} \mathrm{He}$

10:00 Peeters F, Aeschbach-Hertig W, Holocher J \& Kipfer R:

Excess Air Correction in Groundwater Dating with He Isotopes

10:15 Santella N, Schlosser P, Ho D \& Stute M:

Elevated $\mathrm{SF}_{6}$ Concentrations in Soil Air Near New York City and its Effect on the Utility of $\mathrm{SF}_{6}$ for Dating of Groundwater

10:30 Sivan O, Yechieli Y, Herut B \& Lazar B:

Geochemical Evolution of Seawater Intruding into a Coastal Aquifer

\&) 10:45 Loosî̀ HH \& Purtschert R:

INV How can SUSTAINABILITY in Groundwater use be Determined?

11:00 Bonotto DM:

Dual Evaluation of the U-isotopes Modelling for Brazilian Groundwaters

11:15 Morgenstern U:

INV Natural ${ }^{32} \mathrm{Si}$ as Environmental Tracer

11:30 Mahara Y:

INV Groundwater Dating using Dissolved Helium and ${ }^{36} \mathrm{Cl} / \mathrm{C}$

11:45 Castro MC \& Goblet P:

INV Calibration of Regional Groundwater Flow Models - Working Toward a Better Understanding of Site-specific Systems: He Insights

\section{Symposium S34}

Room B/Ja

High-temperature Organic Geochemistry and the Thermal Alteration of Petroleum

\section{Convenors:}

Jeff Seewald, Steve Larter \& Everett Shock

08:30 Helgeson HC \& Richard L

KEY A Chemical and Thermodynamic Model of Oil Generation in the Earth

09:15 Richard L \& Helgeson $H$ :

INV Thermodynamic Analysis of Pyrobitumen Formation during Thermal Alteration of Crude Oil in Deep Hot Reservoir and Source Rocks

09:30 Aplin AC, Love G, Dale J, Bennett B, Taylor G \& Larter S:

INV Alkylphenols and Light Aromatic Hydrocarbons in Oilfield Waters are Produced in Source Rocks, not from Petroleum Hydrolysis

09:45 Seewald J:

Petroleum Decomposition Under Redox-controlled Aqueous Conditions

10:00 van Aarssen B, Bastow T, Alexander R \& Kagi R:

INV Carbocation Reactions in Sediments: The Liquid Reaction Environment

10:15 Sun Y \& Xu S:

High Molecular Weight Polynuclear Aromatic Hydrocarbons as Indicators for High Temperature Alteration of Reservoired oil

10:30 Mango F:

INV Thermal Stability of Hydrocarbons in Sedimentary Basins

10:45 Manning D \& Cross M:

INV EPSL Frontiers Lecture: BSR, TSR and VFAs: Clues and Keys to Reservoir Processes

11:00 Cathles LM \& Losh S:

Implications of Gas Washing of Oil in the Offshore Louisiana Gulf of Mexico Basin

11:15 Mimura K, Arao T, Sugiura M \& Sugisaki R:

INV Shock Reaction of Phenanthrene

11:30 Kenig F, Simons D, Crich D, Cowen J, Ventura G \& Brown T:

INV Alkanes with a Quaternary Carbon Centre: A 2,200 Myr. Record of Sulfide Oxidizing Bacteria

11:45 Williams L, Canfield B, Holloway J \& Williams P

INV Smectite Incubation of Organic Molecules Under Seafloor Hydrothermal Conditions

12:00 Cox JS \& Seward TM:

Reaction Kinetics of Aspartic Acid Solutions at Elevated Temperatures

12:15 Oelkers E, Ruhier L \& Gout R:

An Experimental Study of Aqueous Formic Acid Decomposition Rates as a Function of $\mathrm{pH}$ and Temperature from 175 to $250^{\circ} \mathrm{C}$ 


\section{Symposium S36}

Room B/Pi

Biogenic Substances and their Effect on Trace Metal Cycling and Mineral Weathering

\section{Convenors:}

\section{Stephan Kraemer \& Javiera Cervini-Silva}

08:30 Nitsche $\mathrm{H}$ :

INV Selected Microbial Interactions with Actinides

08:45 Gadd GM:

INV Fungal Influence on Mineral Dissolution and Metal Mobility: Mechanisms and Biogeochemical Relevance

09:00 Frimmel FH, Delay M \& Vercammen K:

INV Fluorescence Spectroscopic and Chromatographic Evidence for the Interaction of NOM and Metal Ions

09:15 Maurice $\mathbf{P}$ :

INV Microbially Mediated Dissolution of Clays: Effects of Siderophores

09:30 Cervini-Silva J \& Sposito G:

Adsorption of Desferrioxamine-B and Oxalate on Al-goethite: Implications for Microbial Dissolution Processes

09:45 Reichard PU, Kretzschmar R \& Kraemer SM:

Fast Ligand Controlled Goethite Dissolution Kinetics Under Non-steady State Conditions in the Presence of Siderophores and Oxalate

or 10:00 Kendall T \& Hochella, Jr. MF:

INV Probing Siderophore-mineral Interaction using Force Measurements

10:15 Lemelle L, Oger P, Simionovici A, Lesourd M \& Gillet P:

An in situ Experimental Study of the Bacterial Colonization and Weathering of Silicate Surfaces

10:30 Nowack B:

Reactions of Biogenic Ligands in the Presence of Metals - What can we Learn from Studying Anthropogenic Chelating Agents?

10:45 Maier R \& Pemberton J:

INV Biosurfactant-mediated Metal Behavior in Soil

11:00 Gorby Y, McLean J, Pinchuk G, Hill E \& Dohnalkova A:

Regulation and Assembly of Extracellular Polymeric Substances by the Facultative Metal Reducing Bacterium Shewanella Oneidensis Strain MR-1

11:15 Myneni S, Edwards D \& Strathman T:

INV Molecular Investigation of Natural Organic Molecules and their Complexes using Soft X-rays

11:30 Peskleway CD, Henderson GS \& Wicks FJ:

Carboxylate Ions and Nordstrandite Growth: AFM Surface Observations

11:45 Ruiz J, Mathur R, Young S \& Brantley S:

Controls of Copper Isotope Fractionation

\section{Symposium S40}

\section{Room A/Fm}

Noble Gases in Geochemistry and Cosmochemistry

Convenors:

Don Porcelli, Chris Ballentine \& Rainer Wieler

08:30 Turner G, Harrison D \& Herrington R:

INV Mantle Helium in Sulphides Deposited in a Palaeozoic Arc Setting

08:45 Kurz M, Curtice J, Lott III D, Fornari D \& Geist D:

INV Noble Gases from the Deep Mantle: New Evidence from Oceanic Volcanism

09:00 Mouatt J, Harrison D, Turner G \& Thirlwall M:

Geographical Variation of ${ }^{3} \mathrm{He} /{ }^{4} \mathrm{He}$ Ratios within the Canary Islands

09:15 Gautheron CE \& Moreira M:

Rare Gas Systematics on North Atlantic Basalts $\left(33\right.$ to $\left.45^{\circ} \mathrm{N}\right)$

09:30 Dixon ET:

INV He and NE Ratios in Icelandic Basalts

09:45 Harrison D, Barry T \& Turner G:

INV Variable ${ }^{3} \mathrm{He} /{ }^{4} \mathrm{He}$ Ratios in Volcanic Lavas Caused by Isotopic Fractionation

10:00 Sarda P:

Pressure Influence on Ar Solubility in Tholeiite Melt

10:15 Kaneoka I:

How are Pristine Noble Gas Signatures of the Earth's Interior Affected by Secondary Processes?

10:30 Moreira M \& Kaminski E:

INV Evaluation of the Rare Gas Contents in the Mantle and the 'Helium Paradox'

10:45 Sumino H, Nagao K \& Notsu K:

Trace of Mantle Plume beneath Southwest Japan Revealed by Noble Gas Isotopes

11:00 Hopp J, Trieloff M \& Altherr R:

Light Noble Gases in the Lithospheric Mantle of the Red Sea Region

11:15 Yamamoto J, Kaneoka I, Nakai S, Kagi H, Prikhod'ko V \& Arai S: Extremely Low ${ }^{3} \mathrm{He} /{ }^{4} \mathrm{He}$ Ratios Observed in Siberian Mantle Xenoliths

11:30 Bouikine A, Korotchantseva E, Hopp J, Schwarz W, Althaus T \& Trieloff M: $\mathrm{He}, \mathrm{Ne}, \mathrm{Ar}$-isotope Composition of Mantle Xenoliths from Dreiser Weiher, West Eifel, Germany 


\section{Symposium G01}

\section{Geochronology}

\section{Convenors:}

Urs Schaltegger, Mike Cosca \& Jost Eikenberg

13:30 Weber B, López-Martìnez M \& Forsythe L:

Island Arc Origin of the El Arco Porphyry Copper Deposit, Baja California: Evidence from ${ }^{40} \mathrm{Ar}-{ }^{39} \mathrm{Ar}$ Dating and Radiogenic Isotopes

13:45 Kirk J, Ruiz J \& Chesley J:

A Major Gold-bearing Crust-forming Event at $3.03 \mathrm{Ga}$

14:00 Harlavan Y, Weinberger R, Ilani S, Tarawneh K, Rabba I \& Steinitz G:

$\mathrm{K}-\mathrm{Ar}$ Ages, Pb Isotopes and Geochemistry of Basalts from Ash Shaam Volcanic Field, NE Jordan

14:15 Meshik A, C. M. Hohenberg, Pravdivtseva OV \& Bernatowicz TJ:

Geochemical Measurements of ${ }^{130} \mathrm{Te}$ Half-life: Present Status

14:30 Poller U, Geisler T, Huth J \& Pidgeon R:

Understanding CL in Natural Zircons

14:45 Ludwig KR \& Mundil R:

Extracting Reliable U-Pb Ages and Errors from Complex Populations of Zircons from Phanerozoic Tuffs

15:00 Rios DC, Conceição H, Davis DW, Rosa MdLdS \& Marinho MM:

The Oldest Zircons from the South America Continent

er 15:15 Dunn SJ, Nemchin A, Cawood P \& Pidgeon R:

Detrital Zircons from the Jack Hills Metasediments, Western Australia: Provenance Record of the Earth's Oldest Material

15:30 Gopalan K, Sarangi S \& Kumar S:

$\mathrm{Pb}-\mathrm{Pb}$ Age of Earliest Megascopic, Eukaryotic Algae Bearing Vindhyan Sediments, India

15:45 Krogh T, Kamo S \& Kwok YY:

An Isotope Dilution, Etch Abrasion Solution to the Akilia Island U-Pb Age Controversy

\section{Symposium G04}

\section{Biogeochemistry}

Convenors:

Karl Föllmi, Maria Dittrich \& Jorge Spangenberg

13:30 Lerman A, Ver LMB \& Mackenzie FT:

Biogeochemical Limits on Greening of the Earth

13:45 Föllmi KB, Tamburini F, Hosein R, Van de Schootbrugge B \& Arn K: The Phosphorus Burial Curve Revisited

14:00 Westphal E \& Strauss H:

Contributions to our Understanding of the Global Sulfur Cycle: Evidence from Paleozoic Sediments

14:15 Peters-Kottig W, Strauss H \& Kerp H:

The Carbon Isotopic Composition of Terrestrial Organic Matter in the Late Paleozoic: Clues to Deciphering the Landplant-atmosphere Interaction

14:30 Suchi E \& Ostertag-Henning C:

Nutrient Replenishment in Late Palaeozoic Oceans

14:45 Sigleo AC:

Stable Isotopic Indicators of Nutrient Cycling in a Temperate North Pacific Estuary, OR, USA

15:00 Russell M \& Rosell-Melé A:

Biomarkers and Climate Proxies, Lake Baikal, Siberia

15:15 Brumsack H, Dellwig O, Kölsch S, Reuter R \& Terjung F:

Are Water Column Signatures of the NW German Backbarrier Tidal Flat Influenced by Microbial Activity?

15:30 Ogrinc N \& Faganeli J:

Sources of the Dissolved Inorganic Carbon in Shallow Coastal Waters

15:45 Szramek K \& Walter L:

Carbonate Equilibria and Mass Transport in Surface Waters

(Symposium G04 Continued in Session 23am on Page 72) 


\section{Symposium S03}

Early Differentiation of Earth and Other Planets

\section{Convenors:}

Mini Wadhwa, Monica Grady, Kevin Zahnle

13:30 Agee C:

KEY Experimental Constraints on Core Formation

14:00 Rushmer T, Humayun M \& Campbell A:

Siderophile Elements in Dynamically Segregated Metallic Liquids

14:15 Rubie D, Melosh J, Reid J, Liebske C \& Righter K:

Mechanisms of Metal-silicate Equilibration in the Terrestrial Magma Ocean

14:30 Danielson L, Sharp T \& Hervig R:

High P and T Partitioning of Au: Constraints on Core Formation

14:45 Hallidav A, Lee D, Fehr M, Quitté G, Porcelli D \& Rehkämper M:

KEY Accretion and Accredited Anomalies

15:15 Kleine T, Münker C, Mezger K, Palme H \& Bischoff A

Revised Hf-W Ages for Core Formation in Planetary Bodies

15:30 Yin Q, Jacobsen SB, Yamashita K, Blichert-Toft J, Telouk P \& Albarède F:

${ }^{182} \mathrm{Hf}-{ }^{182} \mathrm{~W}$ in Meteorites and the Timescale for Planetary Formation

15:45 Münker C, Pfänder J, Büchl A, Weyer S \& Mezger K:

The Influence of Core Formation on Nb-Ta Budgets of Terrestrial Planets

${ }^{182} \mathrm{Hf}-{ }^{182} \mathrm{~W}$, Accretion of the Earth and Origin of the Moon

(Symposium S03 Continued in Session 23am on Page 73)

Symposium S10

\section{Room C/A1}

\section{Geodynamics and Deep Earth Reservoirs}

Convenors:

John Lassiter, Peter van Keken \& John Brodholt

13:30 Tolstikhin I \& Hofmann A:

Generation of a Long-lived Primitive Mantle Reservoir during Late Stages of Earth Accretion

13:45 Goldstein SL, Langmuir CH \& Su Y:

Do we Need a Primitive Mantle Reservoir? An Updated Assessment

14:00 Carlson R:

KEY EPSL Frontiers Lecture: Reservoirs or Recycling?

14:30 Albarède $F$ \& van der Hilst $R$ :

INV Zoned Mantle Convection

14:45 Tatsumi Y \& Kogiso T:

The Subduction Factory: Its Role in the Evolution of the Mantle Reservoirs

15:00 Simon L \& Lecuyer C:

Continental Recycling: The Oxygen Isotope Point of View

15:15 Schaltegger U, Amundsen H, Jamtveit B, Frank M, Griffin WL \& Grönvold K: Contamination of OIB by Underlying Ancient Continental Lithosphere: U-Pb and Hf Isotopes in Zircons Question EM1 and EM2 Mantle Components

15:30 Kellogg L:

INV Heterogeneity in the Lower Mantle: Constraints from Numerical Models and Chemical Geodynamics

15:45 Tackley PJ \& Xie S:

INV Isotopic Evolution of the Mantle in Numerical Models of Mantle Convection and Plate Tectonics

(Symposium S10 Continued in Session 23am on Page 73) 


\section{Symposium S17}

Room C/A2

Magma Chambers and Ore-forming Processes at the Magmatic - Hydrothermal Interface

\section{Convenors:}

\section{Symposium S19}

Innovative Interpretations of Experimental and Field Geochemical Processes Using Reactive Transport Modeling

Convenors:

C. Steefel, C. Ayora \& P. Van Cappellen

13:30 Van Cappellen $P$ \& Regnier $P$ :

KEY Reactive Transport in Complex Biogeochemical Systems

14:00 Jakobsen $\mathrm{R}$ :

Including Stagnant Zones in Order to Model Overlapping Redox Processes Occurring in a Shallow Sandy Aquifer

14:15 Jaffe P \& Xu S:

Trace-metal Dynamics in Wetland Sediments; Laboratory Measurements and Numerical Simulations

14:30 Taillefert M \& Gaillard J:

Reactive Transport Modeling of Trace Metals in Stratified Water Columns

14:45 Regnier P, Laverman A, Pallud C, Van Lith Y \& Van Cappellen P: From Process-oriented Laboratory Experiments to the Modelling of Complex Natural Systems: Incorporation of Microbial Dynamics in a Biogeochemical Reaction Network Simulator Based on the Concept of a "Knowledge Base"

\section{5:00 Furukawa Y, Kostka J \& Smith A:} Multicomponent Inverse Modelling in Aquatic Sediments

\section{5:00 Menuge J, Barton M, Seeger C \& Brewer T:}

The Relationship of Fe Oxide-P-REE Mineralisation to Magmatism: The Pea Ridge Deposit, Missouri

15:15 Wood SA \& Samson IM:

INV The Hydrothermal Geochemistry of Tungsten in Granitoid Environments Solubilities of Ferberite and Scheelite as a Function of T, P, pH and Salinity

15:30 Beuchat S, Moritz R \& Pettke T:

The $\mathrm{Zn}-\mathrm{Pb}-\mathrm{Ag}$ San Cristobal District, Central Peru: Isotope and Fluid Inclusion Constraints

15:45 Bach W, Barriga F, Binns R, Roberts S, Vanko D \& Yeats C:

Anatomy of a Dacite-hosted Submarine Hydrothermal System - Results from Drilling at PACMANUS
15:15 Meile C \& Van Cappellen P:

Global Benthic Fluxes: Importance of Enhanced Solute Transport in Marine Sediments

15:30 Aagaard P, Zheng Z \& Breedveld G:

Modeling Natural Attenuation of Petroleum Contaminants in Aquifers: Conceptional Model and Simulations

15:45 Salas J \& Ayora C:

Groundwater Geochemistry and Dissolution Processes of the Okélobondo Uranium Ore (Gabon) 


\section{Symposium S22}

\section{Erosion Factory II}

Convenors: Jerome Gaillardet \& Bernhard Peucker-Ehrenbrink

14:30 Gislason SR, Kardjilov MI, Gisladottir G, Eiriksdottir ES, Sigfusson B \& Elefsen S:

INV A Quantitative Field Based Study of Basalt/basaltic Glass Weathering and its Role in Carbon Fixation

14:45 Wolff-Boenisch D, Gíslason SR \& Oelkers EH:

Dissolution Rates of Volcanic Glasses of Different Chemical Compositions

15:00 Köhler S, Dufaud F \& Oelkers E:

An Experimental Study of Illite Dissolution Kinetics as a Function of $\mathrm{pH}$ from 1.4 to 12.4 and Temperature from 5 to $50^{\circ} \mathrm{C}$

15:15 Robinson Z, Fairchild I, Spiro B \& Russell A:

Weathering Reactions within a Basaltic Glacial Outwash Plain

15:30 Dupré B, Dessert C, François L, Godderis Y, Allègre CJ \& Gaillardet J:

INV The Role of Basalt Chemical Weathering on the $\mathrm{CO}_{2}$ Cycle

15:45 Arn K, Hosein R, Föllmi KB, Steinmann P, Kramers J \& Aubert D:

Sr Isotope Systematics in Two Glaciated Crystalline Catchments in the Swiss Alps

16:00 Hosein R, Arn K, Houn S \& Karl F:

Detrital Phosphorus Weathering Rates and Mechanisms: Comparing Tropical and Glacial Catchments

16:15 Petelet-Giraud E, Negrel P \& Casanova J:

Constraining the Sr Isotopes Signature in Surface Waters Draining Granite-gneiss by Atmospheric and Anthropic Inputs Correction

(Symposium S22 Continued in Session 23am on Page 74)
Symposium S26

Room B/Fo

Mediterranean Sapropels and their Relationship to Global Climate Variations

Convenors: $\quad$ Gert J. De Lange, Hans-J. Brumsack, Philip A. Meyers \& Judith A. McKenzie

13:30 Emeis K:

KEY Hypotheses and Facts on the When, Why and How of Sapropel Formation in the Mediterranean Sea

13:45 Rohling EJ:

INV Ecology and Shell Chemistry: A Whole-fauna Stable Isotope Study of Eemian Sapropel S5

14:00 Scrivner AE, Vance D \& Rohling EJ:

INV Nd Data for the Nile, Eastern Mediterranean and Forams Document Nile Outflow Increases during S1 and S5

14:15 Martinez-Ruiz F, Paytan A, Kastner M \& Bernasconi S:

INV Geochemical Evidence for Enhanced Productivity and Paleoclimate Reconstruction during S1 Sapropel Deposition in the Mediterranean

14:30 Cacho I, Sierro F, Shackleton N, Elderfield H \& Grimalt J:

INV Reconstructing Alboran Sea Hydrography during the Last Organic Rich Layer Formation

14:45 Overmann J:

INV Bacteria and their Relevance during Formation and Preservation of Sapropels 


\section{Symposium S28}

Ice Age Terminations and Other Rapid Climate Changes

Convenors: Gideon Henderson, Claudine Stirling \& Joerg Schaefer

15:00 Broecker W, Clark E \& Piotrowski A:

KEY $\mathrm{CaCO}_{3}$ Preservation and Dissolution Events: What are They Trying to Tell us?

15:30 Phillips F \& Bowen D:

INV A Comparison of Cosmogenic Chronologies for Deglaciation in Western North America and Europe

15:45 Schaefer JM, Ivy-Ochs S, Denton GH, Schluechter C, Kubik PW \& Schlosser P:

Rise and Fall of the Last Glacial Maximum in Southern Mid-latitudes

16:00 Stone J, Balco G, Sugden D, Caffee M, Siddoway C \& Cowdery S: $10^{3}-10^{6}$ Year History of the West Antarctic Ice Sheet

16:15 Oberholzer P, Schaefer JM, Baroni C, Ivy-Ochs S, Orombelli G \& Baur H: Limited Pleistocene Glaciation in Deep Freeze Range, Northern Victoria Land, Antarctica, Derived from In-situ Cosmogenic Nuclides

(Symposium S28 Continued in Session 23am on Page 76)
Symposium S31

\section{Environmental Tracers for Groundwater Dating}

\section{Convenors:}

\section{Gisela Winckler \& Bernhard Lehmann}

13:30 Lehmann B, Purtschert R, Love A, Kutschera W, Beyerle U \& Frape $S$

${ }^{81} \mathrm{Kr}$ Calibration of ${ }^{36} \mathrm{Cl}$ - and ${ }^{4} \mathrm{He}$-evolution in the Western Great Artesian Basin Australia

13:45 Sturchio NC, Sultan M, Lu ZT, Du X, Lehmann BE \& Purtschert R:

Residence Time of Nubian Aquifer Water, Western Desert, Egypt

14:00 Gavrieli I, Bar-Matthews M, Halicz L, Ayalon A, Gur D \& Burg A:

Hydrological Stability in Carbonate Aquifers over the Last $250 \mathrm{kyr}$ as Reflected by ${ }^{234} \mathrm{U} /{ }^{238} \mathrm{U}$ in Groundwater, Speleothems and Tufa

14:15 Tolstikhin I, Kamensky I, Gannibal M, Tarakanov S, Lehmann B \& Waber H:

INV Residence Time of Helium Isotopes in Sediments and Related Groundwaters, Molasse Basin, Northern Switzerland 


\section{Symposium S38}

Advances in Tracing Sources and Fates of Pollutants in Ground Waters

\section{Convenors:}

\section{Stefan Haderlein \& Nadya Teutsch}

13:30 Bjerg PL:

KEY Natural Attenuation Processes for Groundwater Contaminants: Current Approaches and Understanding

14:00 Reinhard M, Litwiller E \& Gross B:

INV The Fate of Wastewater Indicator Compounds during Groundwater Recharge

14:15 Höhener P, Dakhel N, Pasteris G \& Werner D:

INV Fate of MTBE Relative to Ethanol and Benzene in the Unsaturated Zone

14:30 Meckenstock R, Morasch B, Vieth A, Richnow HH \& Griebler C:

INV Anaerobic Degradation of Aromatic Hydrocarbons as Monitored by ${ }^{13} \mathrm{C} /{ }^{12} \mathrm{C}$ Stable Isotope Fractionation and Specific Metabolites

14:45 Steinbach A \& Michaelis W:

Carbon and Hydrogen Isotope Fractionation of Organic Pollutants in Aquifers

15:00 Zwank L, Luzi S, Berg M, Schmidt TC \& Haderlein SB:

Stable Isotope Analysis of Volatile Organic Contaminants at Trace Levels

15:15 Aravena R, Brown C, Schiff S \& Elgood R:

INV Use of Geochemical and Isotope Tools to Evaluate Nitrate Attenuation in Riparian Wetlands in Agricultural Landscape in Southern Ontario

15:30 Pennisi M, Bianchini G, Cerbai N, Cioni R, Gonfiantini R \& Muti A:

Boron-rich Groundwaters in Alluvial Aquifers of Tuscany: Memory Effect of Past Geothermal Activity?

15:45 Vengosh A, Marei A, Guerrot C, Pankratov I \& Kloppmann W:

INV An Enigmatic Salinity Source in the Mediterranean Coastal Aquifer and Gaza Strip: Utilization of Isotopic (B, Sr, O) Constraints for Searching the Sources of Groundwater Contamination

\section{Symposium S41}

Room A/Fm

The Stable Isotope Geochemistry of "Heavy" Elements

Convenors:

13:30 O’Nions K \& Zhu X:

MED Natural and Experimental Mass Fractionation of Transition Metal Isotopes

14:00 von Blanckenburg $F$ \& Walczyk $T$ :

INV Iron Isotope Fractionation by the Human Body, Animals and Plants

14:15 Chang VT, Belshaw N, Makishima A, Williams RJP, Zhu X \& O'Nions RK:

INV $\mathrm{Mg}$ and $\mathrm{Ca}$ Isotope Fractionation during $\mathrm{CaCO}_{3}$ Biomineralization

14:30 Zhu X, Guo Y \& O’Nions K:

Spatial and Temporal Variations of Transition Metal Isotopes in Ocean

14:45

Siebert C, Nägler TF, von Blanckenburg F \& Kramers JD:

The Oceanic Mo Cycle over the Past $60 \mathrm{Ma}$

15:00 McManus J, Nägler T, Siebert C, Wheat G \& Hammond D: Oceanic Molybdenum Isotope Fractionation: Diagenesis and Hydrothermal Ridgeflank Alteration

15:15 Barling J \& Anbar A:

Mo Scavenging by Manganese Oxyhydroxides and the Seawater Mo Isotope Record in Oxic Sediments

15:30 Arnold GL, Anbar A \& Barling J:

Oxygenation of Proterozoic Oceans: Insight from Molybdenum Isotopes

15:45 Rehkämper M, Frank M, Hein J, Nielsen S \& Halliday A:

Secular Variation of Tl Isotopes in Ferromanganese Crusts?

(Symposium S41 Continued in Session 23am on Page 76) 


\section{Symposium G04}

\section{Special Poster Session: 22am \\ Biogeochemistry}

\section{Convenors:}

\section{Karl Föllmi, Maria Dittrich \& Jorge Spangenberg}

230

Arnosti C \& Holmer M:

Carbon Cycling in a Continental Margin Sediment: Contrasts between Organic Matter Characteristics and Remineralization Rates and Pathways

231 Berg U, Donnert D, Song Y, Reinhardt M, Neumann T \& Weidler PG:

Use of Calcite for the Retention of Phosphorus in Lake Sediments and P-recovery Applications

232 Borgendahl J \& Westman P

Natural Causes for Cyanobacterial Blooms in the Baltic Sea

233 Bosselmann K, Boettcher ME, Theune A, Hespenheide B \& Lilienthal S:

$\mathrm{S}-\mathrm{Fe}-\mathrm{Mn}$ Biogeochemistry of Temperate Intertidal Sediments of the North Sea

234 Böttcher ME, Khim B, Suzuki A, Gehre M, Wortmann U \& Brumsack H:

Microbial Sulfate Reduction in Deep Sediments of ODP Leg 181: Evidence from Stable Sulfur Isotope Fractionation and Pore Water Modeling

235 Cennamo P, Ciniglia C, Valentino GM \& Stanzione D:

Interaction between Acidic Geothermal Waters and Algae Living in Pisciarelli (Naples, Italy)

236 Enel M:

Element Contents in the Ash of Dropwort Roots and in the Soil Around the Roots

237 Faivre D, Zuddas $P$, Agrinier P, Guyot F \& Menguy N:

Significance of Oxygen Isotopic Signature in Magnetite $\left[\mathrm{Fe}_{3} \mathrm{O}_{4}\right]$ Under Earth Surface Conditions: Preliminary Results

238 Gazit-Yaari N, Lazar B \& Erez J:

Depletion Factor as a Paleodepth Indicator

239 Goldberg T, Guo Q, Liu C, Steiner M \& Strauss H:

Isotopic Investigation of the Sulphur and Carbon Cycles in Sedimentary Rocks from the Yangtze Platform, Southern China

240 Juillet-Leclerc A \& Yiou P.

The Measured Coral Oxygen Isotopes Result of the Superimposition of Two Fractionations

241 Kovac N, Bajt O, Faganeli J, Sket B \& Orel B:

Spectroscopic Studies (FT-IR, ${ }^{13} \mathrm{C}$ and ${ }^{1} \mathrm{H}-\mathrm{NMR}$ ) of Macroaggregates in the Northern Adriatic

242 Kovalevskii A \& Kovalevskaya O:

Physiological Role of Bioliths in Plants Life

243 Lysenko O \& Merkylueva N:

The Role of Aminoacids for Technogenic Radionuclide Migration in Soils

244 Müller AB, Strauss H \& Littke R:

Evolution of Late Paloeozoic Terrestrial Environments: The Early Permian Lake Systems in the Saar-Nahe Basin, Western Germany
245 Nilsson MR, Becker ML, Rasbury ET \& Dobson C:

Analyses of Proteins in Natural Carbonates: Recent Aragonitic Ooids, Great Bahama Bank

246 Ouyang Z, Ji H, Wang S, Yang R \& Wang S:

Geochemical Compositions of Carbonate Rocks and their Acid-insoluble Residues: Implications for the Genesis of Dolomite

247 Sah SP \& Brumme R:

The Natural Abundance of ${ }^{15} \mathrm{~N}$ and ${ }^{13} \mathrm{C}$ in the Soil and Needle of the Pine Fores (Pinus roxburghii) along Altitudinal Gradient in Nepal

248 Schneider C \& Exley C:

Looking for Equilibrium: The Determination of an Equilibrium Constant to Describe the Formation of Hydroxyaluminosilicates (HAS)

249 Schroll E, Kucha H \& Stumpfl E:

Bacteriogenic Lead-zinc Mineralization in the Bleiberg Deposit, Austria

250 Schubert CJ, Niggemann J, Ferdelman TF, Klockgether G \& Joergensen BB The Chlorin-Index: A New Parameter for Organic Matter Freshness in Sediments

251 Schulz-Gade W \& Peiffer S:

The Coupling of the Oxidation of Reduced Sulfur Compounds with the Reduction of Fe(III)-Minerals

252 Sobotovich E, Korkushko O, Lysenko O \& Shatilo V:

Whether or not the Isotope Relation Among the Biogenic Elements is Being an Indicator of Organism's Functional State?

253 Strekopytov $\mathrm{S} \&$ Larsen O:

Oxidation of Hydrogen Sulfide by Fe(III) in Phyllosilicates

254 Taunton A, Wood S \& Gunter M:

The Thermodynamics of Asbestos Mineral Dissolution and Conversion in the Human Lung

255 Uchida M, Shibata Y, Harada N, Ahagon N \& Yoneda M:

Compound-specific Radiocarbon Ages of Biomarkers in the Western North Pacific Marginal Sea Sediments

Waldner P, Schneebeli M, Schwikowski M, Stähli M \& Flühler H:

Nitrate Release from a Melting Snowpack

257 Wersin P, Johnson CA \& Furrer G:

Antimony Contamination in Soil and Ground Water by Shooting Range Activities

Yabuta H, Mita $\mathrm{H}$ \& Shimoyama A:

Aliphatic Hydrocarbons in the K/T Boundary Sediments at Kawaruppu, Hokkaido, Japan 


\section{Symposium G05}

\section{Igneous Geochemistry}

\section{Convenors:}

Alfons Berger, Alan Thompson \& Helen Williams

037 Alpaslan M, Otlu N, Ekici T, Temel A \& Boztug D:

Some Textural and Geochemical Evidences on Mixing and Mingling in the Genesis of Karamagara Volcanics, Saraykent-Yozgat, Central Anatolia, Turkey

038 Arnaud N, Agranier A, Chazot G, Pin C, Poidevin J \& Blichert Toft J:

High-K Magmas from the French Massif Central: Crust-mantle Interaction during the Hercynian Orogeny

039 Aslan Z, Kaygusuz A, Sen C \& Arslan M:

Petrographical and Geochemical Features of the Mafic Microgranuler Enclaves in the Upper Cretaceous Aged Torul (Gümüshane) and Sarihan (Bayburt) Granitoids, NE Turkey

040 Dacheng J, Hu R \& Lu Y:

The Mantle Source of the Agpaitic Lamprophyre in Northeastern Hunan Province, China

041 Day S \& Wood S:

The New Wave in Geochemistry Publishing - Electronic Journals

042 Dobnikar M, Fioretti AM, Bellieni G \& Dolenec T:

Amphibole Mineral Chemistry of Rocks of Karavanke Granitic Massif

징 043 Dobosi G, Kempton PD, Downes H \& Embey-Isztin A:

Formation of Lower Continental Crust by Tectonic Emplacement of Oceanic Crust. An Example: The Pannonian Basin

044 Doe BR:

The $\mathrm{Ce} / \mathrm{Yb}$ vs. Ba/Ce Plot in Volcanic and Tectonic Classification

045 Dolgopolova A, Dulski P, Seltmann R \& Weiss D:

REE Characteristics of Technogenic Products of the Orlovka Ta Granite

046 Doucet S, Scoates JS, Weis D \& Giret A:

High-MgO Basalts and Picrites from the Kerguelen Archipelago: Inferences for the Composition of the Kerguelen Mantle Plume

047 Ferrara G, Forte C, Petrini R, Slejko F \& Tonarini S:

Melt/biotite ${ }^{11} \mathrm{~B} /{ }^{10} \mathrm{~B}$ Isotopic Fractionation and the Boron Local Environment in the Structure of Volcanic Glasses

048 Ghorbani MR, Rostami G \& Ghaderi M:

A Lamprophyric Dyke from Milakuh, SW Damghan, Iran

049 Hegazy H:

Petrogenesis and Solidification History of Late Pan-African Dykes Assemblage, Northern Eastern Desert, Egypt

050 Hesse $M$ \& Grove $T$ :

Absarokites from the Western Mexican Volcanic Zone: Constraints on Mantle Wedge Conditions

\section{Ilbeyli N \& Pearce JA:}

Geochemical Characteristics of Cretaceous Collision-related Plutonism in Turkey

New Insight into Petrology, Geochemistry and Dating of the Vejen Pluton

$053 \quad$ Kani T, Takahashi E \& Nohda S:

Isotope Geochemistry of Submarine Lavas from South Arch Volcanic Field, Hawaii

054 Kaygusuz A, Aslan A \& Sen C:

Petrography and Petrology of Torul and Sarihan Plutons, the Eastern Pontides, Turkey

$055 \quad$ Kwon S \& Sagong H:

Regional Nd-Sr-Pb Isotopic Differences of the Mesozoic Granitoids in South Korea: Implications for the Basement Structure

056 Lassen B, Hattori K, Percival J \& Waight T:

Unusually Depleted Hf Isotopic Signatures in Late Archean Carbonatite: A Result of Carbonate Metasomatism

$057 \quad$ Liu Y, Ye L, Li C \& Liu J:

Preliminary Study on Geochemistry of Nanwenhe Later-Silurian Granite, SE Yunnan, China

058 Lustrino M, Melluso L, Morra V, Vannucci R \& Zanetti A:

Ultramafic Xenoliths from Nosy Be Island (N Madagascar)

059 Ni P \& Rankin AH:

A Possible Magmatic Origin of Bayan Obo Fe-Nb-REE Deposit, China

060 Obst K \& Rehfeldt T:

Mineral Chemistry of Mafic and Ultramafic Xenoliths from Jurassic Basalts in Southern Sweden

061 Pertsev A, Batanova V, Ariskin A \& Mochalov A:

Plutonic Evolution of an Island-arc Picritic Magma: Galmoenan Massif, Koryak Highland, Far East Russia

062 Pinto Ferreira V, Valley J, Sial A \& Spicuzza M:

Oxygen Isotopes and Granitoid Series Characterization in the Borborema Province, Northeastern Brazil

063 Rao A:

Rheology of the Proterozoic Massif Anorthosites

064 Siebel W, Chen F \& Satir M:

Geochemistry and Zircon Ages of Variscan S-type Granites from the Western Bohemian Massif

065 Souvent P, Fioretti A, Bellieni G \& Dolenec T:

Petrology of Tourmaline-rich Pegmatites from the Ravne District (Slovenia)

066 Tavares Ferreira PL, Murton B \& Munha J:

Small Scale Geochemical Variability in the Basalts from the Lucky Strike Hydrothermal Field

$067 \quad$ Varol E, Temel A \& Yurur T:

Petrology and Geochemistry of Çamlidere Volcanic Rocks, Central Anatolia, Turkey: Preliminary Results

Vrabec M \& Dolenec T:

Some Genetic Characteristics of Pegmatite Veins from the Pohorje Mountains (Slovenia)

069 Yilmaz H, Alpaslan M \& Temel A:

Petrographic and Geochemical Evidences Indicating the Crustal Assimilation in the Within-plate Basalts: Karasar Basalt (Divrisi-Sivas, Central Anatolia, Turkey 
Zhang H, Xu Z \& Liu C:

Geochemistry of Proterozoic Basic-ultrabasic Volcanics from the West of Yangtze Plate: Implications for the Crust-mantle Evolution

071 Zhang Y \& Xu Z:

Cooling Rates and Temperature in Eruption Columns Inferred from the Hydrous Species Geospeedometer

072 Zhi X, Reisberg L, Wagner C, Peng Z \& Xu X:

Longevity and Multistage Evolution of Subcontinental Lithospheric Mantle beneath Eastern China: Evidence from Re-Os Isotope Geochemistry of Mantle Peridotite Xenoliths from Jiangsu and Anhui Provinces, China

\section{Symposium G06}

Metamorphic Geochemistry and Crustal Fluids

\section{Convenors:}

Lucas Baumgartner \& Stoeff Heinrich

163 Boschi C, Frueh-Green GL \& Kelley DS:

Serpentinization and Carbonate Precipitation at the Lost City Vent Field $\left(30^{\circ} \mathrm{N}\right.$, MAR)

164 Brouwer FM \& Sorensen SS

Whole-rock and Mineral Trace Element Distributions in Alpine and Franciscan Eclogites

165 Fukuyama M, Nishiyama T \& Urata K:

Reaction Zones and Composite Veins Around the Metamorphosed Basic Dykes in the Hirao Limestone, Fukuoka, Japan

166 Ge C \& Ni P:

Fluid Geochemistry of an Ancient Analog to the Modern Seafloor Polymetallic Massive Sulfides- Yongping Super-large Copper Deposit, Jiangxi Province, China

167 Giorgis D, Rumble D \& Cosca M:

Negative $\delta^{18} \mathrm{O}$ Signatures in Morphologically Complex Zircons: Evidence for Proterozoic Cold-climate Water/rock Interaction in the Qinglongshan UHP Meta-granite (Sulu Terrain, China)

168 Handler M, Sorensen S \& Vicenzi E:

Microanalytical Characterisation of Hydrothermal Fluid Interaction with Feldspar Phenocrysts, Alta Andesite, Comstock Lode Region, Nevada

169 Katzir Y, Bröcker M, Valley JW \& Spicuzza MJ:

Oxygen Isotope Variations in Cycladic Eclogites: Assessing the Significance of Zircon Ages

170 Klemm L, Graeser S, Mullis J, Pettke T \& Heinrich C:

Metamorphic Pb-Ag Mineralization at Albrunpass (Central Alps)

171 Koschinsky A, Halbach P, Sander S, Michaelis W \& Seifert R:

Hydrothermal Fluids in the North Fiji Basin and Lesser Antilles

172 Kovalev K \& Naumov E:

Gold and Silver in Massive Sulfide Deposits in Asian Areas of Russia

173 Petrov V:

Metalliferous Black Shales in Precambrian of Siberian Platform

174 Prakashnarasimha K \& Srikantappa C:

Geochemical Characteristics Across the Archaean Dharwar Craton and Late Archaean Nilgiri Granulites, South India

175 Putnis C \& Mezger K:

Isotopic Tracing of a Mineral Replacement Reaction: The $\mathrm{KCl}-\mathrm{KBr}-\mathrm{H}_{2} \mathrm{O}$ System as a Model Example

176 Roselle GT, Bowman JR \& Huang S:

Modeling the Effects of Reaction Kinetics, Diffusion-dispersion, and Fluid Infiltration on Mixed-volatile $\left(\mathrm{CO}_{2}-\mathrm{H}_{2} \mathrm{O}\right)$ Metamorphic Reactions 
177 Shao S \& Zhang Q:

The Geochemistry of the Early Proterozoic Dahongshan Group, in Yunnan Province, West-south China

178 Skublov S:

REE Pattern of Amphibole Replacing Garnet

179 Sohrin Y, Kishida K, Okamura K \& Ishibashi J:

Tungsten and Molybdenum in Hydrothermal Fluids of the Izu-Bonin Arc and the Okinawa Trough

180 Steppan N, Kalt A \& Altherr R:

Partitioning of Li, Be and B between Minerals in Metapelitic Rocks - Case Studies of Ikaria Island (Greece), Künisches Gebirge (Germany), Campo Tencia (Swiss Alps)

\section{Symposium G10}

\section{Computational Geochemistry}

Convenor:

Thomas Driesner

275 Dunkl I \& Székely B:

Component Analysis with Visualization of Fitting ? PopShare, a Windows Program for Data Analysis

276 Li Z, Tu G, Li C, Hu R, Ni S \& Wang J:

Mineralization Processes Modeling of Shangmanggang Gold Deposit, Yunnan, China

277 Palyanova G, Pavlova G, Borisenko A \& Borovikov A:

Au-Ag Mineralization Formation at Dukat Deposit (NE Russia)

278 Sedano LA, Martin PL, Barcala JM, Campos R, Villar MV \& Rivas P.

Development of Advanced Tools for Modelling Wind's Tests

279 Szocs T:

$1 \mathrm{D}$ Geochemical Modelling using NETPATH and PHREEQCI (South-West Hungary)

280 Velo A, Fernandez-Bastero S, Garcia T, Vilas F, Santos A \& Gago-Duport L: Numerical Modelling of Competitive Nucleation Pathways 
Symposium S03

Early Differentiation of Earth and Other Planets

\section{Convenors:}

Mini Wadhwa, Monica Grady, Kevin Zahnle

140 Bizzarro M, Baker JA \& Haack H:

Hf-Nd Isotope Geochemistry of Chondrites

141 Buhre S, Jacob D \& Foley S:

Experimental Evidence for Shallow Recycling of Ocean Crust in the Archean Earth

142 Kadik A, Pineau F, Litvin Y \& Javoy M:

The Dissolution of Hydrogen and Carbon in the Reduced Silicate Melt

143 Osmaston MF:

Lunar Constraints on Core Formation: A New Model with Many Implications

144 Sharkov E \& Bogatikov O:

Early Differentiation of the Earth and the Moon: Evidence from Development of Tectonic-magmatic Processes on These Planetary Bodies

\section{Symposium S04 \\ Special Poster Session: 23am Impact Hazards from Comets and Asteroids}

\section{Convenor:}

Philippe Claeys

146 Agrinier P, Alexander D, Urs S \& Isabelle M:

Short Lifetime for $\mathrm{CO}_{2}$ in the Atmosphere after a Meteorite Impact on Sediments

147

Rodriguez-Tovar FJ, Martinez-Ruiz F \& Bernasconi SM:

Carbon Isotope Composition of Bioturbation Infills as Indication of the Macrobenthic-colonization Timing Across the Cretaceous-Tertiary Boundary (Agost Section, SE Spain)

148 Shukla P, Shukla A, Montanari A \& Bhandari N:

\section{Symposium S08}

Special Poster Session: 22pm

\section{Komatiites}

Convenors:

Nicholas Arndt, Janne Blichert-Toft \& Tim Grove

015 Beresford S, Lahaye Y, Cas R, Jane M, Lambert D \& Stone B:

Re-evaluation of the Genesis of Kambalda-style Komatiite-hosted Ni-Cu-(PGE) ore Deposits

016 Dowling SE, Hill R, Barnes S \& Thordarson T:

Decoupled Hybrid Boundary Layers at the Base of Komatiite Lava Pathways: Omnipresent Components of Actively Eroding Lava Pathways

017 Hill R, Barnes S, Dowling S, Perring C \& Thordarson T:

Emplacement of Komatiite Flow Fields: An Inflationary Model Based on Field Evidence and Modern Mafic Analogues

018 Lesher CM, Houle MG, Levesque M, Gibson HL, Williams DA \& Kerr RC:

Geochemical, Mineralogical, Textural, and Fluid Dynamic Constraints on Endogenous Growth in Differentiated Komatiite Flows

019 Thompson PME, Kempton PD, White RV, Saunders AD, Kerr AC \& Tarney J: Hf-Nd Isotope Systematics of the Gorgona Komatiites, and their Relationship with the Caribbean Plateau

020 Trofimovs J, Cas R \& Davis B:

Intrusive Komatiites: Field Evidence from the Kalgoorlie Terrane, Yilgarn Craton, Western Australia 


\section{Symposium S10 \\ Special Poster Session: 22am \\ Geodynamics and Deep Earth Reservoirs}

\section{Convenors:}

\section{John Lassiter, Peter van Keken \& John Brodholt}

112 Agranier A, Blichert-Toft J, Schilling J, Nelson B \& Albarède F:

$\mathrm{Hf}-\mathrm{Pb}$ Isotope Systematics in MORB along the Reykjanes Ridge $\left(50-64^{\circ} \mathrm{N}\right)$

113 Andres M, Blichert-Toft J \& Schilling J:

Evolution of the Depleted Asthenosphere beneath the Atlantic: Evidence from $\varepsilon \mathrm{Hf}$ in $\mathrm{N}-\mathrm{MORB}$ from $80^{\circ} \mathrm{N}$ to $55^{\circ} \mathrm{S}$

114 Aulbach S, Griffin WL, O'Reilly SY \& Kivi K:

Sulfides from the Lower Mantle?

115 Barry T, Kempton P \& Saunders A:

Hf Isotopes from the Ninetyeast Ridge

116 Batanova V, Bruegmann G, Bazylev B \& Sobolev A

PGE Abundances and Os Isotopes of the Depleted Mantle: Constraints from Ophiolite Peridotites

117 Belyatsky B, Sushchevskaya N \& Beltenev V:

Enriched Tholeiitic Basalts of the Equatorial Atlantic: A Possible Role of the African Subcontinental Mantle

118 Büchl A, Münker C, Mezger K \& Hofmann AW:

I19 Choi SH, Kwon S, Sagong H \& Cheong C:

$\mathrm{Sr}, \mathrm{Nd}$ and $\mathrm{Pb}$ Isotopic Investigations of Late Cenozoic Alkali Basalts and their Ultramafic Xenoliths in South Korea: A Mixing Zone in the Source Mantle beneath East Asia

120 Coussaert N, André L, Mercier JC \& Demaiffe D:

Geochemical Evidence for Metasomatic Clinopyroxenes in Lesotho Peridotites

121 Escrig S, Doucelance R \& Moreira M:

$\mathrm{Os}, \mathrm{Sr}, \mathrm{Nd}, \mathrm{Pb}$ Isotopic Systematics in Basalts and Carbonatites from Fogo Island, Cape Verde

122 Ferrachat S \& Kellogg LH:

Simulating Partial Melting and Chemical Fractionation in Mantle Dynamics Models Galer SJ:

New Perspectives on the Crust-mantle Invariant Ratio Mass Balance

124

Gasperini D, Macera P, Maffei K, Morten L \& Rizzo G:

"Plum-cake" Subcontinental Mantle beneath SE Alps as Resulting from the Geochemistry of Mantle Xenoliths

125 Ionov D \& Weis D:

Hf-Nd-Sr Isotope Relationships in Spinel and Garnet Facies Peridotite Xenoliths: Inferences for the Age and Evolution of the Lithospheric Mantle

126 Jeffcoate AB, Elliott T \& Ionov DA:

$\mathrm{Li}$ Isotopes Fractionation in the Mantle

127 Kamenetsky M, Sobolev A, Sobolev N \& Pokhilenko N:

Kimberlite Parental Melts: New Insights from Inclusions in Olivine
128 Kempton PD, Thompson P \& Saunders A:

Did the Ancestral Hawaii Plume Interact with a Mid-ocean Ridge? The Isotopic Evidence

129 Malfère J, Fontignie D, Blichert-Toft J \& Schilling J:

$\mathrm{Hf}$ and $\mathrm{Pb}$ Isotope Systematics in Basalts from the Iceland Neovolcanic Zones

130 Morgan WJ \& Phipps Morgan J:

Rare Gases Suggest That the MORB Source was Made by OIB/EMORB Melt Extraction from the Mantle

131 Nomade $S$, Feraud G, Renne P \& Chen Y:

New ${ }^{40} \mathrm{Ar} /{ }^{39} \mathrm{Ar}$ Ages for Central Atlantic Magmatic Province in French Guyana: A Younger Volcanism?

132 Parkinson I, Schaefer B, ODP Leg 192 Shipboard Scientists \& Arculus R:

A Lower Mantle Origin for the World's Biggest LIP? a High Precision Os Isotope Isochron from Ontong Java Plateau Basalts Drilled on ODP Leg 192

133 Pearson N, Griffin W, O'Reilly S \& Delpech G:

Magnesium Isotopic Composition of the Lithospheric Mantle: An In-situ Study of Mantle-derived Olivine

134 Schaefer BF, Parkinson IJ, Hole MJ, Kerr AC, Scarrow JH \& Rogers NW:

Re-Os Isotope Systematics of the British Tertiary Volcanic Province; Multiple Mantle Sources in the Proto-Iceland Plume

135 Shimoda G, Nohda S \& Morishita Y:

Role of Adakitic Magma in Producing EMI and EMII Reservoirs

136 Simon NSC, Carlson RW, Pearson DG \& Davies GR:

The Lu-Hf Isotope Composition of Cratonic Lithosphere: Disequilibrium between Garnet and Clinopyroxene in Kimberlite Xenoliths

137 van Keken $\mathbf{P}$ \& Ballentine C:

Helium Isotopic Evidence for Mantle Reservoirs: A Matter of Melting?

138 Zartman RE \& Richardson SH:

Evidence from Kimberlitic Zircon for a Decreasing Mantle Th/U

139 Zhou X, Wilde S, Sun M \& Nimchin A:

Local Response to Global Mesozoic Overturn: Inferred from SHRIMP Zircon Dating of Lower Crust Xenoliths, North China Craton 


\section{Symposium S16}

\section{Magmatic Differentiation - Rates and Processes}

\section{Convenors:}

Charlie Bacon \& Steve Blake

022 Barmina GS \& Ariskin AA:

Simulating Primary Phase Equilibria for the Parental Magma and Early Cumulates of the Kiglapait Intrusion

023 Costa F, Scaillet B \& Pichavant M:

Experimental Simulation of Interactions between Evolved Hydrous Liquids and Gabbroic Minerals at 200-400 MPa

024 Gagnevin D, Daly JS \& Poli G

Microchemical Investigation of K-feldspar Megacrysts: Clues to Magma Dynamics in a Plutonic Environment

025 Hellevang B \& Pedersen RB:

Petrogenesis of Plagioclase Phyric Basalt from the Arctic Ridges

026

Testing the Internally Consistent Age Information of U-series Disequilibria in Rhyolites: Inyo Domes, CA

027 Hora JM, Davidson J \& Hobden B

The Role of Mixing in the Evolution of Andesites at Ngauruhoe Volcano, New Zealand: Constraints from Analyses of Crystal Growth Zones

\& 028 Knesel K:

Gradients in Silicic Bodies Caused by Mixing Rather Than Chamber Differentiation

029 Lackey JS, Hinke H \& Valley J:

Tracking Contamination in Felsic Magma Chambers with $\delta^{18} \mathrm{O}$ of Magmatic Garnet and Zircon

030 Marrocchino E, Coltorti M, Visonà D \& Thirwall MF:

Petrology of Pedrazzo Magmatic Complex (Trento, Italy)

031 Renna MR, Tiepolo M, Tribuzio R \& Vannucci R:

Trace Element Behaviour during Magma Mingling: The Case Study of the Gabbrogranite Association of Ota (Western Corsica)

032 Snyder DC, Widom E \& Pietruszka AJ:

Time Scales of Formation of Zoned Magma Chambers: U-series Disequilibria in the Fogo Trachytes

033 Togashi S, Miyaji N, Yasui M, Ukawa M \& Yoshida T:

Geochemical Evolution of Magmas in Fuji Volcano, Japan

034 Wagner C, Deloule E, Fialin M \& Mokhtari A:

Inferences About Magma Reservoir Dynamics from Zoned Clinopyroxenes of an

Alkaline Suite in North Morocco
Nㅗㄴ

Chemical Versus Physical Origins of Rhyolite in a Magma Factory beneath Taupo Volcano, New Zealand

036 Wolff JA, Ramos FC \& Tollstrup DL:

Crustal Transport of Flood Basalt Magma: The Record of Crystal Isotopic Zoning
Symposium S17

Special Poster Session: 23am

Magma Chambers and Ore-forming Processes at the Magmatic - Hydrothermal Interface

Convenors:

Jim Webster \& Werner Halter

001 Bastrakov E, Kamenetsky V, Skirrow R \& Mernagh T:

Chemistry of High-temperature Fluids in Fe-oxide $\mathrm{Cu}$-Au Systems

002 Davidson P, Kamenetsky V, Hollings P, Cooke D \& Frikken P.

Magmatic Fluids Coexisting with Felsic Melts: An Example from Rio Blanco Rhyolite, Chile

003 Deng H, Campbell AJ \& Humayun M:

Platinum Group Elements in Sulfides from Yangliuping Cu-Ni-Pt-Pd Deposit in Sichuan, China

004 Freiberger $\mathbf{R}$ \& Hecht $L$ :

Fluid Evolution and Mineralogy during Multi-stage Hydrothermal Alteration of Quartz-depleted Granites (Episyenites)

005 Lüders V, Niedermann S \& Halbach P:

Helium Isotopic Composition of Fluid Inclusions Hosted in Massive Sulfides from Modern Hydrothermal Systems

006 Peretyazhko I, Zagorsky V, Smirnov S, Mikhailov M, Prokofiev V \& Madyukov I The Model of Pocket Formation in Boron-rich Granitic Pegmatites

007 Pokrovsky B, Sluzhenikin S, Kudriavtsev D, Krivolutskaya N \& Vrublevsky V: Stable Isotope Geochemistry of the Siberian Traps

008 Ponomarchuk V \& Sotnikov V:

${ }^{40} \mathrm{Ar} /{ }^{39} \mathrm{Ar}$ Dating of the Stages of Endogenic Activity at the Paleozoic Cu-Moporphyry Deposits in Southern Siberia

009 Qin X, Du Y, Zhou W \& Zhang H:

Petrologic and Mineralogical Study of Enclaves in Plutons in the Typical Mining Districts of Tongling, Anhui Province and its Bearing on the Process of Magmatism - Metallogeny

010 Reyf F:

Selective Mobilization of Metals from Granitic Melt into Exsolved Fluid and their Separate Deposition during Formation of the F-Be Deposit

011 Schardt C, Yang DJ \& Large PR:

Numerical Modelling of Heat and Fluid Flow in Submarine Terrains

012 Sotnikov V, Ponomarchuk V, Kiseleva V \& Bersina A:

$\left({ }^{8} \mathrm{Sr} /{ }^{86} \mathrm{Sr}\right) 0$ Isotope and Geochemical (F, Cl, REE) Heterogeneity in Apatite and Titanite Mineral Populations from Magmatites of Shakhtama Cu-Mo Porphyry Deposit, Eastern Transbaikalia, Russia

013 Wu G, Deng J, Wen C, Zhao C \& Du Y:

Fluid Inclusion Study of Ore-forming Fluids and its Bearing on the Hydrothermal Minerization of the Datuanshan Copper Deposit of Skarn Type in the Tongling Area, Anhui Province

014 Zhilong H, Chengming Z \& Longfang L:

The law of Gold Activities in Alkaline Basaltic Magma: Evidence from High Temperature and Ultrahigh Pressure Experiments 
Symposium S18

Special Poster Session: 22pm

Properties of Geological Fluids and Solutes - From

Experiment to Simulation

Convenors:

Terry Seward \& Craig Manning

150 Fouquet S, Tagirov B, Schott J, Harrichoury J \& Escalier J:

Experimental Determination of the Stability of Aluminum-borate Complexes in Hydrothermal Solutions

151 Masuda T, Nakashima S, Famin V \& Kaneda H:

Possible "Soft" Natures of S-containing Fluids

152 Naumov E, Borovikov A \& Borisenko A:

Ore-Forming Fluids of $\mathrm{Au}-\mathrm{Hg}$ Deposits

153 Seward TM, Henderson CMB \& Charnock JM:

An EXAFS Study of $\mathrm{Pd}^{2+}$ Solvation in Aqueous Media and Chloride Complexing to $340^{\circ} \mathrm{C}$ at Saturated Vapour Pressure

154 Wood R, Sharygin A, Balashov V, Grafton B \& Xiao C:

Determination of Multiple Ion Association and Ion Mobilities in Aqueous $\mathrm{Li}_{2} \mathrm{SO}_{4}$ and $\mathrm{K}_{2} \mathrm{SO}_{4}$ from Conductance Measurement at Temperatures from $523 \mathrm{~K}$ to $673 \mathrm{~K}$
Special Poster Session: 23am

Symposium S19

Innovative Interpretations of Experimental and Field
eochemical Processes Using Reactive Transport Modeling

Convenors:

C. Steefel, C. Ayora \& P. Van Cappellen

155 Arcos D, Bruno J \& Karnland O

Geochemical Model of the Granite-Bentonite-Groundwater at Äspö (LOT Experiment)

156 Corbella M \& Ayora C:

157 Fluid Mixing and Deep Dissolution of Carbonates

157 Geiger S, Driesner T, Matthai S \& Heinrich C:

Combining Control Volume Finite Element Methods with Realistic Fluid Properties for High-resolution Simulations of Multiphase Flow in Magmatic-hydrothermal Systems

Giambalvo ER, Steefel CI, Fisher AT, Rosenberg ND \& Wheat CG:

Effect of Fluid-Sediment Reaction on Seafloor Hydrothermal Fluxes of Solutes

Jordana S, Guimera J, Duro L, Domenec JA \& Subirana JM:

Modelling an in situ Test of PCE Oxidation using Permanganate

160 Jourabchi $P$, Van Cappellen $P$ \& Regnier P:

Application of Reactive Transport Modelling to the Interpretation of $\mathrm{pH}$ Changes in Sediments

161 Marcuello A, Gómez P, Saaltink M, Ayora C \& Carrera J:

Multi-component Reactive Transport Modelling at the Ratones Uranium Mine (Spain)

162 Rumynin V \& Hoehn E:

Adsorption of ${ }^{90} \mathrm{Sr}$ and ${ }^{137} \mathrm{Cs}$ Under Elevated Temperature and Pressure Conditions 


\section{Symposium S21}

Special Poster Session: 22pm

\section{Erosion Factory I}

\section{Convenors:}

Nathalie Vigier \& Ken Farley

284 Batt GE \& Hurford A:

INV (U-Th)/He Dating and Thermotectonic Re-Evaluation of Red Sea Rift Development in Yemen

285 Dequincey O, Chabaux F, Leprun J \& Clauer N:

Distribution of ${ }^{238} \mathrm{U}$-serie Disequilibria in a Laterite. Geochemical Implications

286 Fabel D, Stroeven A \& Harbor J:

Landscape Preservation Under Ice Sheets

287 Han G \& Liu C:

Characterization of River Waters Draining Carbonate Terrain: A Study of the Rivers in Karst-dominated Terrains, Guizhou Province, China

288 Kirstein L, Jamieson S \& Sinclair H:

Possible Tectonic Control on the Observed Asymmetry of Drainage Networks Across the Ladakh Batholith

289 Kober F, Schlunegger F, Ivy-Ochs S \& Wieler R:

The Dependency of Cosmognenic Nuclides to Climate and Surface Uplift in Transient Landscapes

i $\quad$ Geochemistry of Groundwater from the Morais Massif (NE.Portugal)

291 Perg L, von Blanckenburg F \& Kubik P:

Cosmogenic Nuclide Budget in a Glaciated Mountain Range (W. Alps)

292 Teng $\mathrm{H}$ :

Controls of Undersaturation on Etch Pit Formation

293

Xu Z, Liu C \& Zhang H:

Geochemistry of Dissolved and Suspended Loads of the Xijiang River, China: Weathering Processes and Erosion Rates
Symposium S22

Special Poster Session: 22am

\section{Erosion Factory II}

Convenors:

Jerome Gaillardet \& Bernhard Peucker-Ehrenbrink

294 Durand S \& Chabaux F:

Groundwater Influences on the Chemical Budget of River Water: Clues from U Isotopic Ratios

295 Foster DA, Staubwasser M \& Henderson G:

Ross Sea ${ }^{226} \mathrm{Ra}$ and Ba Profiles Measured by MC-ICP-MS

296 Harouiya N \& Oelkers E:

An Experimental Study of the Affect of Aqueous Fluoride on Quartz, Kaolinite, and Alkali Feldspar Dissolution Rates

297 Hattori Y, Suzuki K, Honda M \& Shimizu H:

Re-Os Isotopic Systematics of the Taklimakan Desert Sands, Moraines and River Sediments Around the Taklimakan Desert, and of Tibetan Soils

298 Jeong GY:

Biotite Oxidation in the Weathering Profiles of Granitic Rocks: Chemistry, Mineralogy, and Implications for Elemental Behavior

299 Lee K, Ryu J \& Chang H:

Isotopic and Elemental Geochemistry of the Han River, Korea: Implications for Water-rock Interaction

300 Li Y, Yang J, Zhang C, Deng B \& Phelps T:

Dissolution of Iron-rich Clay and Sulfur Sequestration by a Sulfate-reducing Bacterium

301 Liebetrau V, Eisenhauer A, Frei R, Bock B, Kronz A \& Hansen BT:

$\mathrm{Pb}$ - and Nd-Isotope Records of Baltic $\mathrm{Mn} / \mathrm{Fe}$-Precipitates: Evidence for Anthropogenic Pollution and Temporal Variation of Circum Baltic Weathering during the Little Ice Age

302 Liu C \& Han G:

Rare Earth Elements in River Waters Draining Karst Terrain, Guizhou, SW China Ma Y, Huo R \& Liu C:

Speciation and Fractionation of Rare Earth Elements in a Lateritic Profile from Southern China: Identification of the Carriers of Ce Anomalies

304 Montagnac P, Köhler S, Dufaud F \& Oelkers E:

An Experimental Study of the Dissolution Stoichiometry and Rates of a Natura Monazite as a Function of Temperature from 5 to $50^{\circ} \mathrm{C}$ and $\mathrm{pH}$ from 1 to 12.3

305 Negrel P \& Petelet-Giraud E:

Rare Earth Elements and Neodymium Isotopic Systematic in the Groundwaters of French Guiana

306 Pierret M, Chabaux F, Clauer N \& Causse C:

Isotopic Variations in the Sediments of the Caspian Sea: A Record for the Quaternary Continental Weathering?

307 Probst A, Godderis Y, Francois L, Labat D, Schott J \& Viville D:

Modelling Chemical Weathering at River Catchment Scale: Design and Calibration of the WiTCh Model

308 Shibata $S$ \& Tanaka $T$ :

Experimental Study for the Dissolution of Rare Earth Elements in Water-rock Interaction 
Symposium S25

Special Poster Session: 22am

\section{Phanerozoic History of Greenhouse Gases}

\section{Convenors:}

\section{Jerry Dickens, Mark Pagani \& David Beerling}

211 Davis S, Fourel F, Stott A, Torn M, Hillaire-Marcel C \& Bilodeau G:

Monitoring Sources and Fluxes of $\mathrm{CO}_{2}$ with High Precision Atmospheric Stable Isotopic Measurements

212 Schovsbo NH:

Carbon Isotope Stratigraphy of Middle Cambrian to Lower Silurian Shales from Baltoscandia: Implications for Presumed Climatic Stability

213 Smith F \& White J:

The Development of Neogene Grasslands in Relation to Climate and Atmospheric $\mathrm{CO}_{2}$ : The Carbon Isotope Ratios of Fossil Phytoliths

\section{Symposium S26}

Special Poster Session: 23am

Mediterranean Sapropels and their Relationship to Global Climate Variations

Convenors: Gert J. De Lange, Hans-J. Brumsack, Philip A. Meyers \& Judith A. McKenzie

201 Arnaboldi M \& Meyers PA:

Geochemical Comparison of Late Pliocene Sapropels from the Vrica Land Section and ODP Sites 964 and 974

202 Bar-Matthews M, Ayalon A, Gilmour M, Matthews A \& Hawkesworth C: Implications for Post-sapropel Aridity on Land in the Eastern Mediterranean Region De Lange GJ:

Palaeoceanographic and Diagenetic Aspects of Sapropel Formation in the Eastern Mediterranean

204 Larrasoaña JC, Roberts AP, Stoner JS \& Richter C:

Gauging Bottom-water Ventilation in the Eastern Mediterranean by Combining Geochemical and Magnetic Data from Sapropel-bearing Sediments

205

Meyers P \& Arnaboldi M:

High-resolution Comparison of Same-age Interrupted Sapropel Sequences from Four ODP Sites 


\section{Symposium S27}

Special Poster Session: 23am

\section{Sources and Sinks of Aerosols and Dust}

\section{Convenors: \\ Bruno Hamelin, Sidney Hemming \& Karen Kohfeld}

222 Fang J, Kawamura K, Ishimura Y \& Matsumoto K:

Carbon Isotopic Composition of Fatty Acids in the Marine Aerosols from the Western North Pacific: Implication for the Source and Atmospheric Transport

223 Gleason J, Johnson T, Rea D, Moore T, Owen R \& Blum J:

Calibrating Eolian Dust Accumulation Rates in the Central North Pacific Pelagic Clay Province

224 Hamamoto R \& Yanagi T:

Seasonal Variation of Sr Isotope Ratios of the Aeolian Dust in Rainwater

225 Hamelin B, Touchard Y, Angeletti B \& Rochette P.

Tracking the Ethiopian Flood Basalt Fallout from $\mathrm{Pb}$ Isotopes in Indian Ocean Sediments

226 Hemming SR

The State of the Northern Hemisphere Winds during Heinrich Events

227 Kanayama S, Yabuki S, Yanagisawa F \& Abe O:

Sr-isotope Composition as a Tracer for Source Identification of Long-range Transported Asian Dust

Major Change in $\mathrm{Pb}$ Inputs to the Eastern Equatorial Pacific Since the Last Deglaciation

229 Yabuki S, Ye W, Kanayama S, Honda M \& Chang Q:

Geochemistry of Loess Sections from High Altitude Region, Yili Basin, NW China

\section{Symposium S28}

Special Poster Session: 22am

Ice Age Terminations and Other Rapid Climate Changes

Convenors: Gideon Henderson, Claudine Stirling \& Joerg Schaefer

214 Bailey T \& Rosenthal Y:

Change in Seawater Chemistry Across the Pliensbachian-Toarcian Boundary: Preconditioning for an Oceanic Anoxic Event?

215 Beets CJ, Beets DJ \& Cleveringa $P$.

Rapid Climate Fluctuations during the Penultimate Deglaciation

216 Kelly M, von Blanckenburg F, Kubik P \& Schluechter C

Surface Exposure Ages of High Elevation Glacial Erosion Forms: An Attempt to Date Deglaciation of the Last Glacial Maximum Ice Cap in the Western Swis Alps

217 Muscheler R, Beer J, Laj C, Kissel C, Mazaud A \& Kubik PW:

${ }^{10} \mathrm{Be}$ and ${ }^{14} \mathrm{C}$ during the Last Deglaciation

218 Rinterknecht V, Raisbeck G, Yiou F, Clark P, Bitinas A \& Marks L: Preliminary ${ }^{10} \mathrm{Be}$ Chronology for the Last Deglaciation of the Southern Scandinavian Ice Sheet

219 Tütken T, Kuznetsova TV, Vennemann TW \& Pfretzschner H:

Late Pleistocene-holocene Climate of Siberia Deduced from Oxygen Isotope Compositions of Mammoth and Horse Bone Phosphate

\section{Symposium S31}

Special Poster Session: 23am

Environmental Tracers for Groundwater Dating

Convenors:

Gisela Winckler \& Bernhard Lehmann

281 Corcho Alvarado JA, Purtschert R, Hofer M, Aeschbach-Hertig W, Kipfer R \& Hinsby K:

Comparison of Residence Time Indicators $\left({ }^{3} \mathrm{H} /{ }^{3} \mathrm{He}, \mathrm{SF}_{6}, \mathrm{CFC}-12\right.$ and $\left.{ }^{85} \mathrm{Kr}\right)$ in Shallow Groundwater: A Case Study in the Odense Aquifer, Denmark

282 Deschamps P, Doucelance R, Ghaleb B, Hillaire-Marcel C \& Michelot J:

Evidence for Micro-scale U-mobility along Sedimentary Discontinuities in a Deep Limestone Formation as Inferred by ${ }^{234} \mathrm{U} /{ }^{238} \mathrm{U}$ Disequilibria

283 Devivier K, Savoye $S$ \& Devol-Brown I:

Has Iodide a Conservative Behaviour Towards Claystones? the Tournemire Argillite Case 
Symposium S34

Special Poster Session: 23am

High-temperature Organic Geochemistry and the Thermal Alteration of Petroleum

Convenors:

Jeff Seewald, Steve Larter \& Everett Shock

314 Cody G, Boctor N, Brandes J, Filley T, Hazen R \& Yoder Jr H:

INV Abiotic Carbon Fixation Promoted by Transition Metal Sulfides Under Hydrothermal Conditions

315 Lavric JV \& Spangenberg JE:

Aromatic Hydrothermal Petroleum from a Mercury Deposit (Idrija, Slovenia)

316 Leif R:

INV Experimental Investigation into the Role of Water during the Thermal Alteration of Aliphatic Hydrocarbons

317 Schwab V, Spangenberg JE \& Hunziker J:

Chemical and Isotopic Variations in Hydrocarbons from a Metamorphic Black Shale Sequence $\left(100-500^{\circ} \mathrm{C}\right)$

318 Sugisaki R, Iida Y, Murayama M \& Mimura K:

INV Field Evidence for Abiotic Syntheses of Organic Matter in Hydrothermal Conditions

319 Warton B, Grice K, Alexander R \& Kagi RI:

Subsurface Carbocation Processes Revealed by Detailed Study of the Aromatic $\mathrm{UCM}$
Symposium S36

Special Poster Session: 23am

Biogenic Substances and their Effect on Trace Metal Cycling and Mineral Weathering

Convenors:

Stephan Kraemer \& Javiera Cervini-Silva

259 Buerge-Weirich D \& Sulzberger B

Formation of $\mathrm{Cu}(\mathrm{I})$ in Natural Water

Buss HL, Luttge A \& Brantley SL:

Etch Pits and Leached Layers on Iron-silicate Surfaces during Siderophorepromoted Dissolution

261 Dahl A, Lalande M, Jackson B, Gaillard J \& Stahl D:

Correlating Bioavailability with Metal Toxicity using a Suite of Analytical Techniques

262 Frazier S, Reichard PU, Kretzschmar R \& Kraemer SM:

Production and Isolation of Phytosiderophores

263 Johnson $\mathrm{K} \&$ Fein JB:

Cd Partitioning in Metal-Mineral-Bacteria Systems: Testing the Surface Complexation Approach

264 Kawano M \& Tomita K

Bacterial Induced Mineralization in the Weathered Sediments

265

Yamamoto K, Yoshida H, Yogo S, Tanaka S, Milodowski A \& Metcalfe R:

A HREE-enriched Biogenic Ferric Redox Band in Tuffaceous Sedimentary Rock 
Symposium S37

Special Poster Session: 23am

Colloids: Their Nature, Reactivity, and Role in the Transport of Pollutants

\section{Convenors:}

\section{Gordon Brown \& Daniel Grolimund}

325 Alonso U, Missana T, Patelli A, Rigato V \& Ravagnan J:

326 Christiansen BC \& Stipp S:

Morphological and Structural Changes during Transformation of Green Rust Fe(II)(III)-hydroxide

327 Dahlqvist $\mathbf{R}$ \& Ingri J:

Behaviour of Ca during Ultrafiltration of River Water

328 Fukushi K, Sato T \& Yanase N:

Sorption of As(V) on Schwertmannite and its Effect on the Transformation

329 Kristensen R \& Stipp $S$ :

In situ Observations of Reductive Dissolution of Colloidal Lepidocrocite $(\gamma$ $\mathrm{FeOOH}$ ) in Ascorbic Acid

330 Lee SY \& Kim SJ:

Sorption of Naphthalene by Organo-clays

331 Machesky M, Ridley M, Wesolowski D \& Palmer D:

The Influence of Temperature on ion Adsorption Phenomena

8332 Missana T, Garcia-Gutiarrez M, Alonso U \& Quiñones J:

Migration of Bentonite Colloids in a Granite Fracture
Symposium S38

Special Poster Session: 23am

Advances in Tracing Sources and Fates of Pollutants in

\section{Groundwaters}

\section{Convenors:}

Stefan Haderlein \& Nadya Teutsch

333 Dold B \& Spangenberg JE:

Study of Water-soluble Sulfates in Tailings Profiles from Porphyry Copper Deposits by Sulfur and Oxygen Isotopes

334 Gassama N, Violette S, d'Ozouville N \& Dia A:

Multiple Origin of Water Salinization in a Coastal Aquifer, South India Geochemical Point of View

335 Huang W, Lerner D, Colin S, Zheng C \& Oswald S:

The Novel Application of an Oxygen Sensitive Fluorescent Indicator to Investigate Biodegradation Processes at a Plume Fringe in Porous Media

336 Morales TA \& Herbert R:

Morales TA \& Herbert R:
Surface Chemistry and Acidic Dissolution of Forsterite

337 Pfeifer H \& Zobrist J:

Arsenic in Deep Groundwater of Switzerland and their Environmental Impact and Health Risk

338 Pombo SA, Schroth MH, Pelz O \& Zeyer J:

Tracing Microbial Activity in a Contaminated Aquifer at the Field Scale using ${ }^{13} \mathrm{C}-$ labeling of Bacterial Fatty Acids

339 Segal-Rozenhaimer M, Shaviv A, Vengosh A, Gavrieli I, Mayer B \& Shavit U: Sources and Processes of Nitrogen along the Lower Jordan River

340 Temgoua $E$ \& Pfeifer $H$ :

Arsenic in Spring Waters and Soils in Southern Switzerland: Evidence of Complex Weathering and Re-deposition Processes

341 Vokal B, Szaran J, Trembaczowski A \& Dolenec T:

The Isotopic Composition of Sulfates in Rivers the Ljubljanica and the Sava in Slovenia 


\section{Symposium S39 \\ Special Poster Session: 22pm \\ New Geochemical Approaches to Energy, Waste and the Environment}

\section{Convenors:}

\section{Reto Giere \& Peter Stille}

342 Amram K \& Ganor J:

Dissolution Kinetics of Smectite Under Acidic Conditions

343 Berner UR \& Kulik DA:

Ca-Al-hydrates: Solid Solutions?

344 Bosbach D, Bosbach D, Rabung T \& Luckscheiter B:

$\mathrm{Cm}$ (III) / Eu(III) Coprecipitation With Powellite $\left(\mathrm{CaMoO}_{4}\right)$ during HLW Glass Corrosion

345 Curti E \& Berner UR:

Solubility of Ra in a Radioactive Repository Environment

346 Dolin V:

Integral Parameter for Balance Estimation of Radionuclides Biogeochemical Current in the Soil-Plant System

347 Ganor J, Cama J \& Metz V:

Coherency of Surface Protonation Data - Implication from Modelling of Dissolution Experiments

Isotopic Study of $\mathrm{CO}_{2}$ and $\mathrm{CH}_{4}$ Out-gassed from Argillites Investigated for Radioactive Waste Repository

349 Hummel W:

The Influence of Cyanide Complexation on the Speciation of Radionuclides

350

Stable Chlorine Isotopes as Tracers of Solute Transport in a Clay-rock Formation (Paris Basin, France)

351 McKinley IG \& Neall FB:

Geochemical Optimisation of EBS Design for HLW

352 Metz V, Cama J \& Ganor J:

Dependence of Smectite Dissolution Rate on Deviation from Equilibrium

353 Molling P, Sunio E, Ching J, Parini M \& Nordquist G:

Multi-disciplinary Analysis of a Flow Barrier in the Tiwi Geothermal Field, Philippines

354 Pabalan R, Yang L \& Browning $L$ :

Effects of Salt Formation on the Chemical Environment of a High-Level Nuclear Waste Repository

Rousset D \& Clauer N:

Acid-leaching of Clay Mineral: A New Dating Method of Fluid-flows?

356 Saylor B, Matisoff G, Morrison P, Janda N \& Zerai B:

Geochemical Reactions during Geologic Sequestration of $\mathrm{CO}_{2}$ in the Rose Run Formation, Ohio USA

357 Schuessler W, Metz V, Kienzler B \& Vejmelka P:

Geochemically Based Source Term Assessment for the Asse Salt Mine - Modelling and Experimental Results
Stille P, Gauthier-Lafaye F, Jensen K, Bracke G, Ewing R \& Louvat D:

REE Migration in Groundwaters Close to the Natural Fission Reactor of Bangombé (Gabon)

359 Thoenen T, Berner U, Curti E, Hummel W \& Pearson J:

The Nagra/PSI Chemical Thermodynamic Data Base

360 Tits J, Wieland E, Dobler J \& Kunz D:

The Uptake of Sr(II) by Calcium Silicate Hydrates: Adsorption Versus Co-precipitation

361 Wellman D \& Icenhower J:

Direct Synthesis of Na-Autunite

362 Yoshida H, Yamamoto K, Yogo S, Tanaka S, Milodowski A \& Metcalfe R:

A Redox Front Migration Process in Sedimentary Rock - Long-term Behavior of Nuclide Migration Relevant to Near-field Processes in Radioactive Waste Disposal

363 Yudintsev S, Stefanovsky S, Jang Y \& Ewing R:

X-ray Study of Actinide Host-Phases Formation

364 Zhu C, Winterle J \& Love E:

Groundwater Recharge in Late Pleistocene and Holocene at Yucca Mountain Nevada USA 


\section{Symposium S40}

Special Poster Session: 22pm

Noble Gases in Geochemistry and Cosmochemistry

\section{Convenors:}

Don Porcelli, Chris Ballentine \& Rainer Wieler

106 Hanyu T, Dunai TJ, Davies GR, Nakai S, Kaneoka I \& Fujii T:

Rare Gas and Sr-Nd-Pb-Hf Isotope Systematics of Deccan Flood Basalts

107 Kulongoski J, Hilton D \& Izbicki J:

Helium Studies in the Mojave Desert, California: Quantifying Mantle and Crustal Additions to the Regional Groundwater System

108 Marrocchi Y, Toplis M, Pik R \& Marty B:

Solubility and Diffusion of Helium in Amorphous Diopside and Anorthite: Measurements Above and Below the Glass Transition

109 Matsuda J \& Matsumoto T:

Helium Trapped in old Porcelain: on the Historical Variation of the He Isotopic Ratio in Air

$110 \quad$ Pi T \& Solé J:

$(\mathrm{U}+\mathrm{Th}) /$ Noble Gas Dating of Fluorite

111 Yokochi R, Pik R, Marty B \& Chazot G:

Extension of the Afar Plume Material: He Isotope Constraints

\section{Symposium S41}

Special Poster Session: 22am

The Stable Isotope Geochemistry of "Heavy" Elements

\section{Convenors:}

Jane Barling, Xiangkun Zhu, Tom Bullen \& Chloé Marechal

101 Cloquet C, Carignan J \& Libourel G:

High Precision Cadmium Isotopic Measurements by MC ICP-MS

102 Lv Z, Liu C, Liu J \& Zhao Z:

Carbon and Boron Isotope Compositions of Ziyang Witherite Deposits in Southern Qinling, China

103 Ohno T, Kouge I \& Hirata T:

Iron Isotopes in Human Blood

104 Wiederhold JG \& von Blanckenburg F:

Iron Isotope Variations in a Complete Natural Soil Catena with Lateral Iron Mobilization and Reprecipitation

105 Zhang H \& Liu C:

${ }^{87} \mathrm{Sr} /{ }^{86} \mathrm{Sr}$ of Apatites from Altay No.3 Pegmatite and its Implications
Symposium S43

Special Poster Session: 22pm

\section{The Isotope Geochemistry of Hydrogen}

Convenors:

John Eiler \& Francois Robert

266 Chikaraishi Y \& Naraoka H:

Hydrogen and Carbon Isotope Fractionation during Lipid Biosynthesis of Terrestrial Plants

267 Kreutz K, Kang S, Mayewski P, Introne D, Qin D \& Wake C:

Spatial Deuterium Excess Patterns in High-elevation Asian Precipitation

\section{Symposium S46}

Special Poster Session: 22pm Technique Developments in Cosmogenic Nuclides

\section{Convenors:}

Susan Ivy-Ochs \& Tim Jull

268 Kubik PW \& Ivy-Ochs S:

INV An Update on the Köfels ${ }^{10} \mathrm{Be}$ and ${ }^{26} \mathrm{Al}$ Production Rates

269 Niedermann S, Hermanns R \& Hetzel R:

Improving the Distinction of Cosmogenic ${ }^{21} \mathrm{Ne}$ from Other Neon Components in Quartz

270 Shuster D, Farley KA \& Vasconcelos PM

Cosmogenic ${ }^{3} \mathrm{He}$ in Goethite

271 Siame L, Bellier O, Baroux E, Sébrier M, Cushing M \& Braucher R:

${ }^{10}$ Be Down-concentration Profiles and High Denudation Rates: Diagnostic Criteria for Identifying Active Deformation? 


\section{Symposium G04}

\section{Biogeochemistry}

Convenors:

Karl Föllmi, Maria Dittrich \& Jorge Spangenberg

08:30 Toporski J, Steele A, Westall F, Thomas-Keptra K \& McKay DS:

Bacterial Silicification - An Experimental Approach

08:45 Mountain BW, Boerema J \& Benning l:

Biosilicification and Biodiversity in Wastewater from Wairakei Power Station, New Zealand

09:00 Alexandre G, Pokrovsky O, Schott J \& Boudou A:

Study of Diatoms/aqueous Solution Interface. I. Testing a Surface Complexation Approach

09:15 Pokrovsky O, Gelabert A, Viers J, Schott J \& Boudou A:

Study of Diatoms/aqueous Solution Interface. II. Interaction of Trace Metals (Zn, $\mathrm{Cu}, \mathrm{Cd}, \mathrm{Pb}, \mathrm{Cr}, \mathrm{Al}$ ) with Freshwater and Marine Diatoms

09:30 Rambeau C, Föllmi K, Adatte T, Matera V, Steinmann P \& Veuve P:

Cadmium Anomalies in Oolitic Carbonates of Bajocian and Oxfordian/Kimmeridgian Age in the Swiss and French Jura Mountains

09:45 Roychoudhury A:

Sulfate Respiration in Extreme Environments: A Kinetic Study

10:00 Koretsky C, Moore C, Meile C, DiChristina T \& Van Cappellen P:

Seasonal Oscillations in Microbial Iron and Sulfate Reduction in Saltmarsh Sediments

10:15 Spangenberg J \& Spanic D:

Biogeochemistry of an Alpine-type Zinc-lead Mineralization

10:30 Wightman PG \& Fein JB:

Adsorption and Precipitation of Iron by Bacillus subtilis Bacterial Cell Walls

10:45 Glasauer SM, Langley $S$ \& Beveridge TJ:

Controls on Fe Reduction and Mineral Formation by a Subsurface Bacterium

11:00 Zopfi J, Wieland A \& Kühl M:

Biogeochemical Cycling of $\mathrm{C}, \mathrm{O}$, and $\mathrm{S}$ in an Iron Rich Hypersaline Microbial Mat

11:15 Miners JS \& Hudson-Edwards KA:

Geochemical Controls on Metal Accumulation in Thames Estuary Eels

11:30 Caradec S, Grossi V, Gilbert F, Guigue C \& Goutx M:

Influence of Redox Oscillation on the Reactivity of Microalgal Fatty Acids in Sediments

11:45 Haas J:

Bioavailability of Clay-Adsorbed U(VI) to Shewanella putrefaciens

(Symposium G04 Continued in Session 23pm on Page 77)
Symposium G06

Room C/S2

Metamorphic Geochemistry and Crustal Fluids

Convenors:

Lucas Baumgartner \& Stoeff Heinrich

08:30 Argles T \& Foster G:

Unraveling an Orogenic Core: Isotopic Studies on the Western Syntaxis of the Himalaya

08:45 Schmickler B, Jacob D \& Foley S:

Zero Eclogites - Half way between Shallow Mantle and Deep Crustal Origins

09:00 Xiao Y, Hoefs J, Zhang Z \& van den Kerkhof A:

Fluid/rock Interactions in UHP Metamorphic Rocks from Drill Holes in Donghai, Sulu, China: Preliminary Results

09:15 Rolland Y, Cox S, Boullier A, Pennachioni G \& Mancktelow N:

Fluid Flow and Element Mobility in Middle-crust Shear Zones of Collisional Orogens: Insights from the Mont Blanc Massif Shear Zone Network

09:30 Rohrmeier M, Quadt AV, Handler R, Ovtcharova M, Ivanov Z \& Heinrich C The Geodynamic Evolution of Hydrothermal Vein Deposits in the Madan Metamorphic Core Complex, Bulgaria

09:45 Baker J, Matthews A \& Mattey DP:

Continuum of Peak Metamorphism in Anatectic Terrains

10:00 Nabelek P, Huff T \& Wilke M:

Carbonic Fluid Production during Regional and Contact Metamorphism in the Black Hills, USA

10:15 Cui X, Nabelek P \& Liu M:

Numerical Modelling of Reactive Flow of Mixed $\mathrm{H}_{2} \mathrm{O}-\mathrm{CO}_{2}$ Fluids and Progress of Calc-silicate Reactions in Contact Aureoles

10:30 Bowman J:

Trends of ${ }^{13} \mathrm{C}^{-18} \mathrm{O}$ Depletion in Metacarbonate Rocks: Records of Hydrodynamic Dispersion during Infiltration-driven Metamorphism?

10:45 Dini A, Tonarini S \& Leeman WP:

$\mathrm{B}$ and Sr Isotope Variations Induced by (Hydro-)Thermal Effects on Pelites

11:00 Wohlers A, Baumgartner L \& Hauzenberger C:

Experimental Investigations of Initial Melt Migration in Pelites

11:15 Berger A \& Rosenberg C:

Preservation of Residue-melt Equilibria in Contact-metamorphic Anatexites: The Effect of Deformation on Rapid Equilibration

11:30 Meth C \& Carlson W:

New Evidence of Diffusion-controlled Garnet Growth during Deformation

11:45 Nishiyama T:

Variational Formulation of the Steady Diffusion Model of a Reaction Zone 


\section{Symposium S03}

Early Differentiation of Earth and Other Planets

\section{Convenors:}

\section{Mini Wadhwa, Monica Grady, Kevin Zahnle}

\& Kevin Righter

08:30 Kasting J:

KEY Geochemical Constraints on the Rise of Atmospheric $\mathrm{O}_{2}$

09:00 Abe Y, Genda $H$ \& Nishikawa K:

A Mixed Proto-atmosphere during the Runaway Accretion

09:15 Marty B, Mathew K \& Marti K:

Martian Xenology

09:30 Solomon SC:

KEY EPSL Frontiers Lecture: Crust and Mantle Evolution on the Terrestrial Planets: A Geophysical Perspective on Early Differentiation

10:00 Valley JW, Cavosie A, Graham C, King E, Peck W \& Wilde SA

Zircon Evidence of the Earliest Archean Crust: 4.0-4.4 Ga

10:15 Nelson DR:

Hadean Earth Crust: Microanalytical Investigation of 4.4 to 4.0 Ga Zircons from Western Australia

10:30 Boyet M, Abarède F, Telouk P \& Rosing M: ${ }^{142} \mathrm{Nd}$ Anomaly Confirmed at Isua

10:45 Caro G, Bourdon B, Birck J \& Moorbath S:

${ }^{142} \mathrm{Nd} /{ }^{144} \mathrm{Nd}$ Precise Determination in Early Archean Rocks

11:00 Kreissig K \& Elliott T:

Fingerprinting Early Continental Evolution using Ca Isotopes

11:15 Bennett V, Nutman A, Friend C \& Norman M:

Geochemical Investigations of the Oldest (>3800 Ma) Abyssal Peridotites: Implications for Early Earth Processes

11:30 Wadhwa $M$ \& Grove $T$ :

Archean Cratons on Mars?: Evidence from Trace Elements, Isotopes and Oxidation States of SNC Magmas

11:45 Weiss B, Vali H, Baudenbacher F, Shuster D, Stewart S \& Kirschvink J: Records of the Ancient Martian Magnetic Field and Climate in ALH84001

\section{Symposium S10}

Room C/A1

\section{Geodynamics and Deep Earth Reservoirs}

Convenors:

John Lassiter, Peter van Keken \& John Brodholt

08:30 Saal AE, Hauri EH, Langmuir CH \& Perfit MR:

INV Vapor Undersaturation in Primitive Mid-ocean Ridge Basalt and the Volatile Content of the Earth's Upper Mantle

08:45 Porcelli D, Ballentine C \& Halliday A:

INV Xe Isotope Evolution of the Mantle

09:00 Trieloff M:

INV Primordial Noble Gases in OIBs: Primitive Mantle or Other Sources?

09:15 Ballentine CJ, Van Keken PE, Porcelli D \& Hauri EH:

INV The Mantle Zero Paradox Noble Gas Concentration

09:30 Lassiter J:

The Influence of Recycled Oceanic Crust on the Potassium and Argon Budget of the Earth

09:45 Phipps Morgan J \& Morgan WJ:

INV Modelling the Joint Rare Gas, Solid-isotope, and Trace Element Evolution of a Multi-component Mantle

10:00 Shim S \& Jeanloz R:

P-V-T Equation of State of $\mathrm{MgSiO}_{3}$ Perovskite and the Chemical Composition of the Lower Mantle

10:15 Boehler R:

INV Phase Behavior and Melting in the Deep Mantle

10:30 Frost DJ \& Langenhorst F:

INV The Oxidation State of Iron in the Lower Mantle

10:45 Dubrovinsky L, Dubrovinskaia N, Rozenberg G, Dmitriev V \& Weber h:

INV Fe-O System at Extreme Conditions

11:00 Mackwell S, Bystricky M, Stretton I \& Heidelbach F:

INV High-Strain Deformation of Mantle Minerals and Seismic Anisotropy

11:15 Jacob D, Bizimis M \& Salters V:

Lu-Hf Isotopic Systematics of Subducted Ancient Oceanic Crust: Roberts Victor Eclogites

11:30 Murphy D, Kamber B \& Collerson K:

Solution of the First Terrestrial Pb-isotope Paradox by Garnetite Accumulation in the Transition Zone

11:45 Pfänder JA, Münker C, Mezger K \& Hofmann AW

In Search of a Superchondritic Nb/Ta Reservoir: High-precision Nb/Ta and Zr/Hf Ratios in Ocean Island and Intraplate Basalts

(Symposium S10 Continued in Session 23pm on Page 78) 


\section{Symposium S16}

\section{Magmatic Differentiation - Rates and Processes}

\section{Convenors:}

Charlie Bacon \& Steve Blake

08:30 Blundy J, Sparks S, Annen C, Brooker R, Melnik O \& Cashman K:

KEY Generation, Ascent and Crystallisation of Calc-alkaline Silicic Magmas

09:00 Bacon CR \& Lanphere MA:

INV Magma Differentiation Rates and Processes at Mount Mazama (Crater Lake), a Cascades Arc Volcano

09:15 Kluska J, Gillot P \& Nativel P:

Differentiation Rates and Geochemical Characterization of Parental Magmas for The Piton des Neiges Volcano (Réunion Island, Indian Ocean)

09:30 Bohrson W \& Spera F:

INV Insights into Magmatic Differentiation: Energy Constrained Open-System Processes

09:45 Ariskin AA:

Parental Magmas for Differentiated Sills and Large Layered Intrusions

10:00 Mushkin A, Stein M, Halicz L \& Navon O:

The Daly Gap: Low-pressure Fractionation and Heat-loss from a Cooling Magma Chamber

10:15 Turner S, Foden J, George R \& Evans P:

A INV Time Scales and Processes of Potassic Magma Generation at Sangeang Api Volcano, Eastern Sunda arc

10:30 George R, Turner S, Hawkesworth C, Nye C, Stelling P \& Dreher S:

INV The Time Scales of Magmatic Differentiation at Island Arcs

10:45 Goldstein S, Cooper K, Reid M, Murrell M \& Sims K:

Effects of Rapid Crystallization on ${ }^{226} \mathrm{Ra}^{230} \mathrm{Th}$ Ages

11:00 Asmerom Y, Mukasa S, Cheng H, Polyak V \& Edwards L:

Timescale of Melt Differentiation from ${ }^{231} \mathrm{~Pa}^{226} \mathrm{Ra}$ Data

11:15 Davidson J, Tepley III F, Hora J \& Knesel K:

INV Magma System Processes Constrained by Mineral-scale Isotope Variations

11:30 Hawkesworth C, Zellmer G \& Sparks S:

INV Magma Evolution and Emplacement Time Scales beneath Montserrat

11:45 Ginibre C \& Wörner G:

INV Progress in Understanding Magma Chambers Based on High-resolution Phenocryst Microprobe Analysis

(Symposium S16 Continued in Session 23pm on Page 79)
Symposium S22

\section{Erosion Factory II}

Convenors:

Jerome Gaillardet \& Bernhard Peucker-Ehrenbrink

08:30 Dessert C, Dupré B, Schott J, Pokrovski O \& Fazlulin S:

Chemical Composition of Kamchatka Rivers, Russia

08:45 France-Lanord C, Galy A \& Singh S:

INV The Climatic Control of Weathering in the Himalayan River System

09:00 Bickle MJ, Bunbury J, Chapman H, Harris N, Fairchild I \& Ahmad T:

Modelling of Carbonate and Silicate Inputs to the Riverine Dissolved Load

09:15 Derry LA, Evans M \& France-Lanord C:

INV Tracing Hydrothermal and Metamorphic Fluxes of $\mathrm{CO}_{2}$ and Solutes from the Central Himalaya

09:30 Kump LR:

$K E Y$ Weathering Through Earth History: Controls and Consequences

10:00 Ding T, Wan D, Wang C \& Zhang F:

$\mathrm{Si}, \mathrm{O}$ and $\mathrm{H}$ Isotopic Compositions of Water and Suspended Materials in the Yangtze River, China

10:15 Riotte J \& Chabaux F

Groundwater Contribution to $\left({ }^{234} \mathrm{U} /{ }^{238} \mathrm{U}\right)$ A.r. of Surface Waters: Mount Cameroon Case

10:30 Chabaux F, Durand S, Schmitt A, Risacher F \& Elsass P:

U-Sr Isotopic Tracing of Water-rocks Interactions in Aquifer: Example of the Pollution of the Rhine Water Table by Salty Waters

10:45 Henderson G, Robinson LF, Smith A, Matthews I, Barker D \& Hall B: EPSL Frontiers Lecture: Weathering Control of River and Ocean $\left({ }^{234} \mathrm{U} /{ }^{238} \mathrm{U}\right)$

11:00 Pistiner JS \& Henderson GM:

Determining the Mechanisms of Lithium Isotope Fractionation during Weathering

11:15 Godfrey L, Chan L, Alonso R, Jordan T \& Lowenstein T: Isotope Constraints on Brine Formation in Closed Basin Salars, NW Argentina

11:30 Huh Y, Chan L \& Chadwick O:

INV Lithium Isotopes as a Probe of Weathering Processes: Hawaiian Soil Climosequence

11:45 Kosler J, Kucera M, Sylvester P \& Libertinova J:

Isotopic Composition of Li in Foraminifera and their Host Sediments

(Symposium S22 Continued in Session 23pm on Page 79) 


\section{Symposium S28}

Room B/Fo

\section{Ice Age Terminations and Other Rapid Climate Changes}

\section{Convenors: Gideon Henderson, Claudine Stirling \& Joerg Schaefer}

08:30 Lea D:

KEY New Insights into Glacial Terminations from Mg-paleothermometry

09:00 Spero H \& Lea D:

The Cause of Carbon Isotope Minimum Events on Glacial Terminations

09:15 McManus JF, Francois R, Gheradi J \& Nuwer J:

INV Variable Rates of Ocean Circulation from Sedimentary ${ }^{231} \mathrm{~Pa} /{ }^{230} \mathrm{Th}$ during the Last Ice Age Termination

09:30 Piotrowski A, Goldstein S \& Hemming S:

North Atlantic Deep Water Strength during the Last Deglaciation from Nd Isotopes

09:45 Rosenthal Y, Oppo D \& Linsley B:

INV The Amplitude and Phasing of Climate Change during the Last Deglaciation in the Sulu Sea, Western Equatorial Pacific

10:00 Koutavas A, Lynch-Stieglitz J \& Marchitto T:

El Niño-La Niña Pattern of Glacial-interglacial Transitions: Evidence from Geochemical Proxies in Foraminifera

10:15 Andres MS, Bernasconi SM \& McKenzie JA:

High-resolution, Southern-Hemisphere Record of Rapid Climate Change at 182

10:30 White J, Popp T, Schilla A, Johnsen S, Jouzel J \& Masson-Delmotte V:

The Timing of Atmosphere and Ocean Changes during an Abrupt Climate Change

10:45 Stein M:

The Fall and Rise of the Dead Sea during the Post-Glacial and the Younger Dryas Event

11:00 Raisbeck G, Yiou F \& Jouzel J:

Cosmogenic ${ }^{10} \mathrm{Be}$ as a High Resolution Correlation Tool for Climate Records

11:15 McGregor HV, Gagan MK, McCulloch MT \& Chappell J:

Abrupt Shift in mid-Holocene Climate in the Western Pacific Warm Pool

11:30 Jung S, Davies G, Ganssen G \& Kroon D:

Decadal-Centennial Scale Climate Variations in the Arabian Sea during the Early Holocene

11:45 Baldini J, McDermott F \& Fairchild I

Speleothem Trace Elements as Palaeohydrological Proxies during the ' 8,200 Year' Cold/dry Event

(Symposium S28 Continued in Session 23pm on Page 80)
Symposium S39

Room B/Ja

New Geochemical Approaches to Energy, Waste and the Environment

\section{Convenors:}

\section{Reto Giere \& Peter Stille}

08:30 Ewing R:

KEY Impact of the Nuclear Fuel Cycle on the Environmen

09:00 Crovisier JL \& Advocat $T$ :

INV The Relevance of Analogues for Long-term Prediction

09:15 Gauthier-Lafaye F, Stille P \& Del Nero M:

INV 2.O b.y old Natural Nuclear Wastes: The Natural Nuclear Reactors in Gabon

09:30 Lumpkin G, Smith K, Gieré R \& Williams T:

INV Assessing the Geochemical Behaviour of Ceramic Nuclear Waste Forms using Natural Samples

09:45 Eikenberg J, Bajo S \& Ruethi M:

Actinide Isotope Analysis for Determining Different Nuclear Fallout Component in Soils

10:30 Glasser FP:

KEY Geochemical Impacts of Combustion Wastes in Reuse and Disposal

11:00 Gieré R, Carleton LE, LaFree ST, Zingg A \& Tishmack JK: Impact of Tire-derived Fuel on the Chemical Composition of Coal-combustion Products

11:15 Donahoe RJ, Yang L, Graham EY, Schexnayder JM \& Howell JR: Secondary Mineral Formation in Coal Ash Disposal Facilities: Implications for Metals Sequestration

11:30 Cama J, Querol X, Ganor J \& Ayora C:

Properties of Fly-ash Synthetic Zeolite NaP1 for Soil Remediation

11:45 Arnórsson S:

INV Chemical Environmental Impact of Geothermal Resource Utilization

$$
\text { (Symposium S39 Continued in Session 23pm on Page 80) }
$$




\section{Symposium S41}

The Stable Isotope Geochemistry of "Heavy" Elements

\section{Convenors:}

Jane Barling, Xiangkun Zhu, Tom Bullen

08:30 Luck J, Ben Othman D \& Albarède F:

INV What do $\mathrm{Cu} / \mathrm{Zn}$ Isotopes Tell us on Meteorites?

08:45 Chen H \& Lee T:

Pitfalls of Ti Isotopic Measurement by Multi-Collecting-ICP-MS

09:00 Guo Y, Maxshima A, Zhu X, Belshaw N, O’Nions K \& Russell S:

High Precision Measurement of Ti Isotopes in Terrestrial and Extraterrestrial Materials

09:15 Nakai S \& Saito T:

Mass Fractionation of tin in Ancient Bronze

09:30 Archer C \& Vance D:

Large Fractionations in $\mathrm{Fe}, \mathrm{Cu}$ and $\mathrm{Zn}$ Isotopes Associated with Archean Microbially-mediated Sulphides

09:45 Larson PB, Ramos FC, Maher K, Gaspar M, Chang Z \& Meinert LD: Cu Isotopes: Tracing Metal Sources in Ore Deposits

10:00 Graham S, Griffin W, Jackson S, Walter M, Logan G \& Pearson N: In-situ $\mathrm{Cu}$ and $\mathrm{Fe}$ Isotope Evidence for Inorganic and Organic Components in the

10:15 Williams H, Lee D, Sylvain L, Nadya T, Franck P \& Mark R:

Fe Isotope Composition of Mid-ocean Ridge Basalts and Mantle Peridotites

10:30 Beard B, Johnson C \& Karen VD:

Iron Isotope Constraints on Fe Cycling and Mass Balance in the Oxygenated Earth

10:45 Rouxel O \& Ludden J:

Abiotic or Biotic Iron Isotope Fractionation during Oceanic Crust Alteration?

11:00 Anbar A, Arnold G, Rye R \& Weyer S:

INV Iron Isotopes in an Archean Paleosol

11:15 Matthews A, Morgans-Bell H, Emmanuel S, Jenkyns HC \& Halicz L:

Cyclic Variations of Iron Isotope Composition during Diagenesis: The Kimmeridge Clay Formation (UK)

11:30 Severmann S, Larsen O, Palmer MR \& Nüster J:

The Isotopic Signature of Fe-mineralisation during Early Diagenesis

11:45 Teutsch N, von Gunten U, Porcelli D \& Halliday A:

Iron Isotope Fractionation in Groundwater

(Symposium S41 Continued in Session 23pm on Page 81)

Symposium S46

$\operatorname{Room~A/St~}$

Technique Developments in Cosmogenic Nuclides

Convenors:

Susan Ivy-Ochs \& Tim Jull

08:30 Stone J:

KEY Calibration and Scaling of Cosmogenic Nuclide Production Rates

09:00 Dunai TJ:

INV Scaling Factors for In-situ Cosmogenic Production, an Attempt to Reach a Working Consensus

09:15 Lifton N, Pigati J, Jull AT \& Quade J:

INV Altitudinal Variation of in situ Cosmogenic ${ }^{14 /} \mathrm{C}$ Production Rates: Preliminary Results from the Southwestern U.S

09:30 Masarik J:

INV Numerical Simulation of In-situ Production of Cosmogenic Nuclides

09:45 Fifield K, Evans J \& Stone J:

INV Calibration of the Production Rate of ${ }^{36} \mathrm{Cl}$ from Potassium

10:00 Licciardi J \& Kurz M:

INV Calibration of Cosmogenic ${ }^{3} \mathrm{He}$ Production Rates from Postglacial Lava Flows in Iceland

10:15 Gaver E, Pik R, France-lanord C, Marty B \& Bourles D:

Cosmogenic ${ }^{3} \mathrm{He}$ Production Rate: Comparison of He and Be Data from Himalayan Samples

10:30 Stuart F, Williams A \& Christiansen H:

INV Towards Determining Cosmogenic ${ }^{3} \mathrm{He}$ Exposure Histories from old Volcanic Rocks

10:45 Bryce J \& Farley K:

${ }^{3} \mathrm{He}$ Exposure Dating of Magnetite

11:00 Shimaoka A, Kong P, Finkel $R$, Caffee M \& Nishiizumi K:

The Determination of in situ Cosmogenic Radionuclides in Olivine

11:15 Hetzel R, Niedermann S, Ivy-Ochs S, Kubik PW, Tao M \& Gao B:

${ }^{21} \mathrm{Ne}$ Versus ${ }^{10} \mathrm{Be}$ Surface Exposure Ages of Quartzite: A Comparison

(Symposium S46 Continued in Session 23pm on Page 81) 


\section{Symposium G04}

\section{Biogeochemistry}

Convenors:

Karl Föllmi, Maria Dittrich \& Jorge Spangenberg

13:30 Eilrich B, Leuenberger M, Burns SJ, Weyhenmeyer CE \& Steinmann P:

Concentration and Carbon Stable Isotope Patterns of Methane and DIC in Deep Peatlands - Implications for the Microbial Methanogenic Pathways and Gas Transport

13:45 Roehm C \& Roulet N:

Dynamics of DOM and its Influence on $\mathrm{CO}_{2}$ and $\mathrm{CH}_{4}$ Production Potentials in a Northern Peatland

14:00 Hartog N, van Bergen PF, Griffioen J, de Leeuw JW \& van der Weijden CH: The Reactivity of Organic Matter in Aquifer Sediments: Geological and Geochemical Controls

14:15 Mayer L \& Schick L:

Dissolved Fluorophore Production from Lipid-Protein Oxidation Reactions

14:30 Liang X, Zhu J \& Wang F:

Fe-Mn-S Cycling and the Distribution of Biomacromolecules and SRB in Lake Sediments from Southwest China

14:45 Moreira NF, Walter LM, McCall PJ, Vasconcelos C \& McKenzie JA: Hydrogeochemistry of a Modern Dolomite-Forming Lagoon System (Cabo FrioRJ, Brazil): Role of Sulfide Oxidation

15:00 Mitchell SW \& Baron D:

Timing and Mechanism of Lacustrine Organogenic Dolomitization, Bahama Islands

15:15 Tuyukina T:

Biogeochemical Specifics of Northern Taiga Ecosystems on Hard Gypsum Regolith

$15: 30$

Perrier T, Martin-Garin A, Mustin C \& Leyval C:

15:45 Mills RA, Severmann $S$, Palmer MR \& Fallick AE:

Hydrothermal Clays as Tracers of Seafloor Sulphide Mound Evolution
Symposium G06

Room C/S2

Metamorphic Geochemistry and Crustal Fluids

Convenors:

Lucas Baumgartner \& Stoeff Heinrich

13:30 Malmström M, Huthwelker T \& Lanford WA:

Non-stoichiometric Dissolution of Biotite: A Preliminary RBS-Study

13:45 Akinfiev NN \& Diamond LW:

Thermodynamic Description of Aqueous Non-electrolytes at Infinite Dilution over a Wide Range of State Parameters

14:00 Garofalo PS, Heinrich CA, G nther D \& Pettke T:

PTX Properties of a Natural Au-bearing Hydrothermal Fluid from a Multidisciplinary Study of Fluid Inclusions (Sigma Deposit - Canada)

14:15 Bakker RJ \& Kleinefeld B:

Fluid Inclusions as Micro-chemical Systems: Evidence and Modelling of Fluid-host Interactions in Plagioclase

14:30 Ghaderi M \& Ghorbani MR:

Tungsten-tin Deposits in Southwest of Shazand, Iran

14:45 Reves AG \& Read S:

Nontronite Formation in Rhyolitic Ignimbrite

15:00 Sato T, Akita N \& Arai S:

Geochemical Modelling of Hyperalkaline Spring Water and Precipitates at the Oman Ophiolite

15:15 Dublyansky Y:

Extreme Crystal-scale Variability of $\delta^{13} \mathrm{C}$ in Hydrothermal Calcite from Yucca Mountain, Nevada

15:30 Smirnov S, Dublyansky Y, Mel'gunov M \& Mel'gunova E:

REE Geochemistry of the Fluorite from Yucca Mountain, USA: Fingerprinting Multiple Sources of Matter in Hydrothermal Fluids

15:45 Gaskova O \& Dublyansky Y:

The Mobility of $\mathrm{U}$ and $\mathrm{Pb}$ in Cooling Aqueous Fluid Evolving from Reduced to Oxidized State 


\section{Symposium S04}

Impact Hazards from Comets and Asteroids

\section{Convenor:}

Philippe Claeys

13:30 Montanari A:

KEY Impact Stratigraphy: Searching for a Needle in the Haystack of the Rock Record

14:00 Becker L \& Poreda R:

Fullerenes and Interplanetary Dust (IDPs) in the Phanerozoic

14:15 Arrhenius G, Lepland A \& Asaro F:

Search for an Extraterrestrial Impact Record in Isua Sediments

14:30 Gerasimov MV, Dikov YP, Yakovlev OI \& Wlotzka F:

Chemical Consequences of an Impact of a Comet: Experimental Simulation

14:45 Genda $H$ \& Abe Y:

Effects of Giant Impacts on the Atmosphere Formation

15:00 Bendtsen J \& Bjerrum C.J:

Vulnerability of the Climate on Earth: Effect of Perturbations in the Insolation Caused by Extra-terrestrial Impacts or Large Volcanic Eruptions

15:15 Golding SD, Uysal IT, Baublys KA, Glikson AY \& Mory AJ:

Stable Isotope Geochemistry of Impact Related Alteration Phases from the Woodleigh Impact Structure, Western Australia
Symposium S10

Room C/A1

\section{Geodynamics and Deep Earth Reservoirs}

Convenors:

John Lassiter, Peter van Keken \& John Brodholt

13:30 Hofmann AW, Abouchami W, Eisele J, Jochum KP, Sobolev A \& Galer S: Anatomy of the Hawaiian Plume: Heterogeneity on Many Scales

13:45 Jull M \& Ribe N:

The Geochemistry of Hawaiian Plume Dynamics

14:00 Sobolev A, Hofmann AW, Shimizu N, Chaussidon M, Metrich $\mathbf{N} \&$ Nikogosian I:

Primary Melts Reveal Small-scale Heterogeneity in Convecting Mantle

14:15 Griselin M \& Lassiter JC:

Extreme Unradiogenic Os Isotopes in Hawaiian Mantle Xenoliths: Implications for Mantle Convection

14:30 Thompson G, Suzuki K, Tatsumi Y \& Honda M:

Osmium Isotopic Signature of EM1 Deduced from Rarotonga Island, Polynesia

14:45 Cooper K, Eiler J \& Asimow P:

Oxygen-isotope Evidence for Altered Oceanic Crust in the Atlantic MORB Source

15:00 Gannoun A, Thomas LE, Burton KW \& Schiano P. Open-system Behaviour in Mid-Ocean Ridge Basalts

15:15 Elliott T, Thomas A, Jeffcoate A \& Niu Y:

Li Isotope Variations in the Upper Mantle

15:30 Breddam K, Peate D, Stecher O \& Baker J:

New Double Spike $\mathrm{Pb}$-isotope Results for Primitive Icelandic Lavas

15:45 Kellogg J, Jacobsen S \& O'Connell R:

Relating Mixing in the Mantle to $\mathrm{Nd}, \mathrm{Sr}$, and $\mathrm{Pb}$ Ratios in Oceanic Basalts 


\section{Symposium S16}

\section{Magmatic Differentiation - Rates and Processes}

\section{Convenors:}

Charlie Bacon \& Steve Blake

13:30 Chakraborty S, Costa F \& Dohmen R:

A Diffusion Model for Calculating Magma Residence Times using Trace Element Zoning in Plagioclase

13:45 Morgan D, Blake S \& Rogers N:

Determination of Crystal Residence Times and Magma Chamber Volumes: Vesuvius 1944

14:00 Annen C, Sparks S \& Blundy J:

Silicic Melt Generation by Basalt Crystallization in the Deep Crust

14:15 Anderson A:

INV Preeruptive Sizes of Bubbles in Bishop Tuff Rhyolitic Magma

14:30 Reid M:

INV Crystal Ages as Tracers of Rhyolite Differentiation and Storage

14:45 Bindeman IN \& Valley JW:

Oxygen Isotope and U-Pb Insights into Dynamics and Longevity of Large Silicic Magma Systems

15:00 Vazquez JA \& Reid MR:

Constraining the Timing of Magmatic Evolution in the Youngest Toba Tuff Rhyolite Through Dating of Zoning in Allanite

15:15 Thomas $\mathrm{L}$, Blake $S$, Kelley $S$ \& Morgan D.

The Evolution of the Youngest Toba Tuff: A Crystal Disequilibrium Study

15:30 Charlier BLA, Davidson JP, Wilson CJN \& Simon JI:

Differentiation Processes in a High-silica Rhyolite as Recorded in Plagioclase Crystals from Taupo Volcano, New Zealand

15:45 Blake S, Sutton A, Wilson C \& Charlier B:

INV The Origin of Rhyolite Magmas and their 'Phenocrysts'
Symposium S22

\section{Erosion Factory II}

Convenors:

\section{Jerome Gaillardet \& Bernhard Peucker-Ehrenbrink}

13:30 Nielsen S, Rehkämper M, Porcelli D, Swarzenski P \& Halliday A: Isotopic Compositions and Concentrations of Estuarine Thallium

13:45 Galy A:

INV Isotopic Composition of Dissolved $\mathrm{Mg}$ in Natural Waters

14:00 Lemarchand $E$, Schott J \& Gaillardet J:

Isotopic Fractionation Related to Boron Sorption on Humic Acids

14:15 Ziegler K, Chadwick OA, Kelly EF \& Brzezinski MA:

INV The $\delta^{30} \mathrm{Si}$ Values of Soil Weathering Profiles: Indicators of Si Pathways at the Lithosphere/hydro(bio)sphere Interface

14:30 Banfield J, Grove E \& Macalady J:

$K E Y$ Biogeochemical vs. Erosional Contributions to Landscape Lowering

15:00 Davies G, Jung S \& Ganssen G:

Abrupt Climate Change in N-Africa: The Asynchronous Termination of the Africa Humid Period

15:15 Sherlock S, Burton K, Kelley S \& Reynolds B

Assessing the Role of Incongruent Weathering

15:30 Burton K, Gannoun A \& Henderson G:

Osmium Isotope Variations in the Oceans: Past and Present

15:45 Ravizza G \& Peucker-Ehrenbrink B:

The Marine Os Isotope Record of the Eocene-Oligocene Transition

16:00 Cohen A, Harding S, Coe A \& Schwark L:

Isotopic and Geochemical Evidence for Changes in Global Weathering during the Toarcian OAE

16:15 Lee CA, Wasserburg GJ \& Kyte FT:

Platinum Group Elements and Re in Marine Sediments Across the K-T Boundary: Constraints on Re-PGE Transport in the Marine Environment 


\section{Symposium S28}

Ice Age Terminations and Other Rapid Climate Changes

Convenors: Gideon Henderson, Claudine Stirling \& Joerg Schaefer

13:30 Battisti D:

KEY Mechanisms Responsible for Abrupt Climate Change

14:00 Delaygue G, Stocker TF, Joos F \& Plattner K:

Sensitivity of the Atmospheric Carbon-14 Content in a Climate Model

14:15 Mangini A:

Stalagmites Indicate a Link between Earth's Magnetic Field and Climate during the Past 200,000 Years

14:30 Esat T \& Yokoyama Y:

INV Rapid Sea-level, Ice-volume and Radiocarbon Excursions during a Heinrich Event at Huon Peninsula

14:45 Vance D \& Archer C:

Isotopic Constraints on the Origin of Heinrich Event Precursors

15:00 Ayalon A, Bar-Matthews M \& Kaufman A:

Climatic Conditions in the Eastern Mediterranean Region during Glacial Marine Isotopic Stage 6

15:15 Spötl C \& Mangini A:

A Th/U Dated Record of the Penultimate Deglaciation, Spannagel Cave, Austrian Alps

15:30 Caillon N, Severinghaus JP \& Jouzel J:

INV Timing of $\mathrm{CO}_{2}$ and Temperature Changes Across Termination-III from Argon Isotopes in Trapped Air from the Vostok Ice Core

15:45 Thompson WG, Spiegelman MW, Goldstein SL \& Speed RC:

The Timing of Glacial Terminations from Open-system Ages of Corals
Symposium S39

Room B/Ja

New Geochemical Approaches to Energy, Waste and the Environment

Convenors:

Reto Giere \& Peter Stille

13:30 Eggenberger $\mathrm{U}$, Bunge $\mathrm{R} \&$ Schenk $\mathrm{K}$ :

INV The Geochemical Impact of MSWI Bottom Ash on the Environment

13:45 Perret D, Stille P, Mäder U \& Schenk K:

INV Vitrified Waste: Route for the Future?

14:00 Johnson C, Baur I \& lachowski E:

INV The use of Cement to Control the Mobility of Heavy Metals in Wastes

14:15 Baur I \& Johnson C:

The Binding of Selenate and Selenite to Cement Minerals

14:30 Bonhoure I, Wieland E, Scheidegger A \& Tits J:

Radionuclides Immobilization by Cement and Cement Phases Studied by EXAFS

15:00 Eighmy T, Crannell B, Eusden D, Butler L \& Cartledge F:

INV Use of Surface Analysis, Solid-state Spectroscopy, and Geochemical Modelling to Characterize Phosphate-stabilized Wastes

15:15 Icenhower J, McGrail P \& Luttge A:

Origins of Deviations from Transition-State Theory: Effects of Ion-Exchange Kinetics in Glass

15:30 Samson S \& Nagy K:

Biotite Dissolution in Simulated Hanford Tank Waste

15:45 Pierce E, Martin W, Serne RJ \& Icenhower J:

Dissolution Kinetics of $\mathrm{UO}_{2}(\mathrm{cr})$ 


\section{Symposium S41}

The Stable Isotope Geochemistry of "Heavy" Elements

\section{Convenors:}

Jane Barling, Xiangkun Zhu, Tom Bullen

13:30 Hoefs J:

KEY Isotope Variations of Heavy Elements: A Perspective from Light Isotopes

14:00 Levasseur S, Warthmann RJ \& Halliday AN:

Fractionation of Fe Isotopes by Anaerobic Phototrophic Bacteria

14:15 Johnson C, Beard B, Welch S, Croal L, Newman D \& Nealson K:

INV Experimental Constraints on Fe Isotope Fractionations during Biogeochemica Cycling of $\mathrm{Fe}$

14:30 Bullen T, White A, Mandernack K \& Witte K:

Iron Isotope Fractionation: Does Equilibrium or Disequilibrium Rule?

14:45 Schauble E, Rossman G \& Taylor H:

Theoretical Estimates of Equilibrium Chromium-isotope Fractionations

15:00 Johnson TM, Ellis AS \& Bullen TD:

INV Cr Stable Isotopes: Measurement, Systematics and Applications

15:15 Marechal CN \& Sheppard SMF:

Isotopic Fractionation of $\mathrm{Cu}$ and $\mathrm{Zn}$ between Chloride and Nitrate Solutions and Malachite or Smithsonite at $30^{\circ}$ and $50^{\circ} \mathrm{C}$

@ $\quad$ 15:30 Galy A, Pokrovsky OS \& Schott J:

Ge-isotopic Fractionation during its Sorption on Goethite: An Experimental Study

Symposium S46

Room A/St

Technique Developments in Cosmogenic Nuclides

\section{Convenors:}

Susan Ivy-Ochs \& Tim Jull

13:30 Lal DL:

KEY Underground Cosmic Ray Geophysics: The New Expanding Frontier

14:00 Nolte E, Heisinger B, Lal D, Kubik PW, Ivy-Ochs S \& Neumaier S

INV Production of Selected Cosmogenic Radionuclides by Muons

14:15 Braucher R, Bourlès DL, Brown ET \& Colin F:

INV Re-evaluation of ${ }^{10} \mathrm{Be}$ Production by Muons

14:30 Phillips F:

INV Mugenic Nuclides: A Method for Dating Rapidly Eroding Landforms

14:45 Klein J \& Gosse J:

INV Production Rates of ${ }^{10} \mathrm{Be}$ and ${ }^{26} \mathrm{Al}$ in Mid-latitudes and High Altitudes

15:00 Bourlès D, Braucher R, Brown E, Kalvoda J \& Mercier J:

$I N V$ Younger Dryas Glacial Expansion in the Discontinously Glaciated Area of Western and Central Europe

15:15 Yokoyama Y, Caffee MW, Finkel RC, Ryerson FJ, Southon JR \& Nishiizumi K:

Extractions of In-situ Produced ${ }^{14} \mathrm{C}$ in Terrestrial Quartz and Measurements of ${ }^{14} \mathrm{C}$ Production Rate using Saturated Quartz

15:30 Carcaillet J, Bourlès DL \& Thouveny N:

High-resolution Authigenic ${ }^{10} \mathrm{Be} /{ }^{9} \mathrm{Be}$ Records: A Proxy Indicator of the Past Geomagnetic Field Variability

15:45 Lorenz R, Jull T, Swindle T \& Lunine J:

INV Radiocarbon on Titan

16:00 Suter M \& Synal HA:

INV New Developments in AMS - What is the Impact to Earth Sciences? 


\section{Goldschmidt 2002}

\section{Index of \\ Programme and Abstract Volumes}

To ensure that each paper can be easily found, this index gives the page numbers of each paper in both this programme volume and in the abstract volume which was prepared for Geochimica et Cosmochimica Acta. Entries in bold indicate a presenting author. Each paper has also been allocated a scheduling code (e.g. S03:22pm26:C/S1) which contains the scheduling information for that paper. The page number in the abstract volume (e.g.A304) also gives the name of the file containing the abstract on the conference website - this abstract can be found at A304.pdf). All abstract file names have 7 letters, thus the abstract on page A4 is found in the file A004.pdf.

The first part of the code gives the symposium (S03), the second part gives the date, session and timeslot of the presentation (22pm26 is Thursday August 22nd in the afternoon in timeslot 26), the third part gives the room or poster board number ( $\mathrm{C} / \mathrm{S} 1$ is lecture room Sanada 1 in Area $\mathrm{C})$.

The times of each timeslot (timeslot 26 is 14:45) and the names of each of the lecture rooms are shown in the tables below. The locations of these rooms, and of each group of poster boards can be found from the Map of the Congress Center (page ii).

\section{Goldschmidt 2002 Times}

am am

pm

pm

$$
\begin{aligned}
& 01=08: 30, \quad 09=10: 30, \quad 21=13: 30, \quad 27=15: 00 \text {, } \\
& 02=08: 45, \quad 10=10: 45, \quad 22=13: 45, \quad 28=15: 15 \text {, } \\
& 03=09: 00, \quad 11=11: 00, \quad 23=14: 00, \quad 29:=15: 30 \text {, } \\
& 04=09: 15, \quad 12=11: 15, \quad 24=14: 15, \quad 30=15: 45 \text {, } \\
& 05=09: 30, \quad 13=11: 30, \quad 25=14: 30, \quad 31=16: 00 \text {, } \\
& 06=09: 45, \quad 14=11: 45, \quad 26=14: 45, \quad 32=16: 15 \text {, } \\
& 07=10: 00, \quad 15=12.00 \text {, } \\
& 08=10: 15, \quad 16=12: 15 \text {, }
\end{aligned}
$$

\section{Goldschmidt 2002 Rooms}

Area A

Area B

$\mathrm{A} / \mathrm{Co}=$ Conference Hall, $\mathrm{B} / \mathrm{Fo}=$ Foyer B1,

$\mathrm{A} / \mathrm{Fm}=$ Forum,$\quad \mathrm{B} / \mathrm{Ja}=$ Jakobshorn,

$\mathrm{A} / \mathrm{St}=$ Studio,$\quad \mathrm{B} / \mathrm{Pi}=$ Pischa/Parsenn, 
Goldschmidt 2002 Index

$\mathrm{S} 40: 22 \mathrm{am} 11: \mathrm{A} / \mathrm{Fm}$ G06:22pmPO:P180 S42:19amPO:P218 S35:19amPO:P245 $\mathrm{S} 35: 21 \mathrm{am} 14: \mathrm{B} / \mathrm{Pi}$ $\mathrm{S} 45: 18 \mathrm{pm} 25: \mathrm{A} / \mathrm{Co}$ S02:19am09:C/S1 S47:19pmPO:P318 $\mathrm{S} 40: 21 \mathrm{am} 06: \mathrm{A} / \mathrm{Fm}$ S44:19amPO:P306 S37:21am14:B/Ja G07:19pm26:B/Ja S39:22pmPO:P342 S30:19pm30:B/Pi S10:22pm28:C/A S11:18amPO:P044 $\mathrm{S} 41: 22 \mathrm{pm} 29: \mathrm{A} / \mathrm{Fm}$ S41:22pm28:A/Fm S41:23am11:A/Fm $\mathrm{S} 44: 18 \mathrm{am} 03: \mathrm{A} / \mathrm{St}$ S20:19am06:A/Co G07:18pmPO:P330 G01:19pmPO:P257 S01:19amPO:P147 G05:21pm30:C/A1 S16:23pm24:C/A2 S18:21am11:C/S2 S10:23pm23:C/A1 S24:19am01:B/Fo S27:22am11:B/Fo $\mathrm{S} 23: 18 \mathrm{pm} 28: \mathrm{B} / \mathrm{Fo}$ S30:18amPO:P248 S42:18am10:B/Fo $\mathrm{S} 37: 21 \mathrm{am} 04: \mathrm{B} / \mathrm{Ja}$ S44:19amPO:P293 S10:22amPO:P120 S10:22amPO:P113 S28:23am08:B/Fo S23:19pmPO:P201 S27:23amPO:P225 G01:19pmPO:P258 S01:18am04:C/S1 S16:23am01:C/A2 S16:23pm23:C/A2 S47:19pmPO:P318 G07:18pmPO:P339 S14:18pmPO:P001 S23:19pmPO:P210 S42:19amPO:P219 S33:19amPO:P243 S34:22am05:B/Ja G05:21 am11:C/A1 S12:19pmPO:P039 S40:22am12:A/Fm G06:23pm27:C/S2

$\mathrm{S} 18: 21 \mathrm{am} 05: \mathrm{C} / \mathrm{S} 2$ $\mathrm{S} 34: 22 \mathrm{am} 12: \mathrm{B} / \mathrm{Ja}$ $\mathrm{S} 32: 18 \mathrm{pm} 30: \mathrm{B} / \mathrm{Pi}$ S38:22pm28:B/Ja S41:23am05:A/Fm $\mathrm{S} 28: 23 \mathrm{pm} 26: \mathrm{B} / \mathrm{Fo}$ $\mathrm{S} 24: 19 \mathrm{pm} 31: \mathrm{B} / \mathrm{Fo}$ S05:19pm31:C/S2 S19:23amPO:P155 S14:19am06:C/A2 S10:22amPO:P132 S13:18am13:C/A2 S25:21am05:B/Fo G06:23am01:C/S2 G05:22pmPO:P061 S16:22pmPO:P022 S16:23am06:C/A2 G04:22pm22:B/Pi S22:22pm30:A/Co $\mathrm{S} 22: 22 \mathrm{pm} 31: \mathrm{A} / \mathrm{C}$ S26:23amPO:P201 S26:23amPO:P205 G05:22pmPO:P038 S08:21 am06:C/A2 S08:21pm30:C/A2 S41:23am11:A/Fm S41:22pm29:A/Fm S01:18am04:C/S1

\begin{tabular}{|c|c|c|c|}
\hline 50 & A339 & Arnórsson S & S39:23am14:B/Ja \\
\hline 60 & A740 & Arnosti C & G04:22amPO:P230 \\
\hline 32 & A16 & Arrhenius G & S07:18am08:C/S2 \\
\hline 32 & A407 & Arrhenius G & S07:18am10:C/S2 \\
\hline 39 & A471 & Arrhenius G & S04:23pm24:C/S1 \\
\hline 2 & A882 & Arslan M & G05:22pmPO:P039 \\
\hline 11 & A552 & Arvidson RS & S48:18am06:B/Ja \\
\hline 12 & A16 & Arvidson RS & S48:19pmPO:P362 \\
\hline 33 & A741 & Arz H & S24:19am04:B/Fo \\
\hline 40 & A614 & Asahara Y & S42:18am07:B/Fo \\
\hline 33 & A836 & Asaro F & S04:23pm24:C/S1 \\
\hline 39 & A17 & Aschepkov I & G01:22am06:A/St \\
\hline 18 & A664 & Ash R & S02:19am07:C/S1 \\
\hline 70 & A17 & Ashchepkov I & S11:18amPO:P044 \\
\hline 22 & A18 & Asimow P & $\mathrm{S} 10: 23 \mathrm{pm} 26: \mathrm{C} / \mathrm{A} 1$ \\
\hline 52 & A673 & Asimow PD & S11:19am08:C/A1 \\
\hline 27 & A34 & Aslan A & G05:22pmPO:P054 \\
\hline 56 & A30 & Aslan Z & G05:22pmPO:P039 \\
\hline 56 & A52 & Asmerom Y & S16:23am11:C/A2 \\
\hline 76 & A18 & Astilleros J & S48:18am01:B/Ja \\
\hline 5 & A771 & Astilleros J & S48:19pmPO:P358 \\
\hline 15 & A19 & Atlas E & $\mathrm{S} 43: 21 \mathrm{am} 03: \mathrm{A} / \mathrm{St}$ \\
\hline 24 & A230 & Aubaud C & S12:18pm28:C/A2 \\
\hline 23 & A19 & Aubaud C & S12:18pm29:C/A2 \\
\hline 26 & A540 & Aubaud C & S12:19pmPO:P039 \\
\hline 41 & A20 & Aubert D & S27:22am05:B/Fo \\
\hline 79 & A21 & Aubert D & $\mathrm{S} 22: 22 \mathrm{pm} 30: \mathrm{A} / \mathrm{Co}$ \\
\hline 37 & A496 & Auclair A & S49:19pm28:A/Fm \\
\hline 78 & A725 & Audétat A & S17:22pm21:C/A2 \\
\hline 15 & A660 & Augustsson C & G01:22am14:A/St \\
\hline 48 & A20 & Aulbach S & S10:22amPO:P114 \\
\hline 9 & A237 & Aumont O & $\mathrm{S} 23: 18 \mathrm{pm} 27: \mathrm{B} / \mathrm{Fo}$ \\
\hline 31 & A21 & Austrheim H & $\mathrm{S} 45: 18 \mathrm{am} 06: \mathrm{A} / \mathrm{Co}$ \\
\hline 5 & A244 & Avino R & $\mathrm{S} 12: 18 \mathrm{pm} 21: \mathrm{C} / \mathrm{A} 2$ \\
\hline 39 & A355 & Ayalon A & $\mathrm{S} 45: 18 \mathrm{pm} 30: \mathrm{A} / \mathrm{Co}$ \\
\hline 33 & A14 & Ayalon A & G03:21pm23:B/Fo \\
\hline 62 & A155 & Ayalon A & G03:21pm28:B/Fo \\
\hline 62 & A22 & Ayalon A & $\mathrm{S} 31: 22 \mathrm{pm} 23: \mathrm{A} / \mathrm{Co}$ \\
\hline 75 & A22 & Ayalon A & S26:23amPO:P202 \\
\hline 30 & A23 & Ayalon A & S28:23pm27:B/Fo \\
\hline 67 & A306 & Ayliffe L & $\mathrm{S} 24: 19 \mathrm{pm} 26: \mathrm{B} / \mathrm{Fo}$ \\
\hline 23 & A860 & Ayora C & $\mathrm{S} 19: 22 \mathrm{am} 10: \mathrm{C} / \mathrm{S} 2$ \\
\hline 2 & A882 & Ayora C & S19:22pm30:C/S2 \\
\hline 74 & A83 & Ayora C & S19:23amPO:P156 \\
\hline 79 & $\mathbf{A 2 3}$ & Ayora C & S19:23amPO:P161 \\
\hline 33 & A741 & Ayora C & $\mathrm{S} 39: 23 \mathrm{am} 13: \mathrm{B} / \mathrm{Ja}$ \\
\hline 25 & A479 & & \\
\hline 29 & A24 & & \\
\hline 30 & A856 & & \\
\hline 32 & A24 & & \\
\hline 32 & A643 & & \\
\hline 49 & A25 & & \\
\hline & A462 & & \\
\hline
\end{tabular}
$50 \quad$ A858 $77 \quad$ A669 $37 \quad \mathrm{~A} 302$ 49 A513 $10 \quad$ A348 $56 \quad$ A25 $\begin{array}{ll}76 & \text { A26 }\end{array}$ $80 \quad$ A798 21 A488 19 A505 $64 \quad$ A26 $14 \quad$ A754 62 A580 3 A71 $38 \quad$ A27 $\begin{array}{ll}72 & \text { A27 }\end{array}$ 58 A593 63 A52 $74 \quad$ A28 51 A239 $\begin{array}{ll}54 & \text { A28 }\end{array}$ $54 \quad$ A 343 66 A29 66 A510 $58 \quad$ A29 $37 \quad$ A225 43 A30 76 A18

Bach W Bach W Bachmann O Bacon C Bacon CR Bacon CR Bacon S

Bada JL Badanina E Badanina E Baeyens B Bahlburg H Bai Z Bailey T Bajo $S$

Bajt O Baker A Baker DR Baker J Baker J Baker J Baker J Baker J G05:22pmPO:P069 Alpaslan M

Altherr R

Altherr R

S15:18am09:C/A1 S15:18am06:C/A1
58 A863

$50 \quad$ A96

4
$4 \quad$ A 846
Arndt N

Arnold G
75 A31

57 A3

3 A448

3 A798

$\begin{array}{ll}78 & \mathbf{A 3 2}\end{array}$

58 A35

$6 \quad$ A32

34 A465

$15 \quad$ A532

$5 \quad \mathbf{A 3 3}$

78 A32

$46 \quad$ A783

$12 \quad$ A33

$27 \quad$ A34

$78 \quad$ A151

14 A34

58 A388

58 A35

74 A35

6 A618

34 A282

$40 \quad$ A622

9 A36

9 A121

$28 \quad$ A605

$48 \quad$ A36

54 A28

$\begin{array}{ll}22 & \text { A37 }\end{array}$

53 A37

$46 \quad$ A38

62 A38

9 A91

6 A280

9 A829

$11 \quad$ A377

$41 \quad$ A14

41 A500

55 A266

66 A49

80 A39

21 A255

48 A660

53 A663

64 A152

64 A483

$75 \quad$ A116 $\begin{array}{lrr}\text { S13:18am05:C/A2 } & 3 & \text { A596 } \\ \text { S33:18am12:B/Pi } & \mathbf{4} & \text { A41 } \\ \text { S17:22pm30:C/A2 } & \mathbf{5 3} & \text { A41 } \\ \text { S20:19pm30:A/Co } & 20 & \text { A565 } \\ \text { S47:19pmPO:P317 } & 33 & \text { A690 } \\ \text { S47:19pmPO:P311 } & 33 & \text { A42 } \\ \text { S16:23am03:C/A2 } & \mathbf{7 4} & \text { A42 } \\ \text { S30:19am05:B/Pi } & 16 & \text { A357 } \\ \text { S05:19pm27:C/S2 } & 19 & \text { A277 } \\ \text { S17:22am05:C/A2 } & \mathbf{4 7} & \text { A43 } \\ \text { S17:22am06:C/A2 } & 47 & \text { A803 } \\ \text { S37:21pm28:B/Ja } & 45 & \text { A163 } \\ \text { G01:22am14:A/St } & 46 & \text { A38 } \\ \text { G05:21pm31:C/A1 } & 41 & \text { A 874 } \\ \text { S28:22amPO:P214 } & 67 & \text { A43 } \\ \text { S39:23am06:B/Ja } & 75 & \text { A210 } \\ \text { G04:22amPO:P241 } & 57 & \text { A414 } \\ \text { S19:22am04:C/S2 } & 48 & \text { A222 } \\ \text { S17:22am07:C/A2 } & 47 & \text { A190 } \\ \text { S44:18am04:A/St } & \mathbf{5} & \text { A44 } \\ \text { S30:19am01:B/Pi } & 16 & \text { A212 } \\ \text { S11:18amPO:P048 } & 27 & \text { A407 } \\ \text { S47:19pmPO:P314 } & 33 & \text { A360 } \\ \text { S44:19amPO:P304 } & 33 & \text { A792 } \\ \text { G05:21am08:C/A1 } & 36 & \text { A703 } \\ \text { G05:21am07:C/A1 } & 36 & \text { A817 } \\ \text { G06:23am06:C/S2 } & 72 & \text { A44 } \\ & & \end{array}$ 
Goldschmidt 2002 Index

\begin{tabular}{|c|c|c|c|c|c|c|c|c|c|c|c|}
\hline Author & Code & Prog. & Abs. & Author & Code & Prog. & Abs. & Author & Code & Prog. & Abs. \\
\hline Baker J & S10:23pm29:C/A1 & 78 & A103 & Bazylev B & S10:22amPO:P116 & 62 & A55 & Bernasconi S & $\mathrm{S} 26: 22 \mathrm{pm} 24: \mathrm{B} / \mathrm{Fo}$ & 54 & A489 \\
\hline Baker JA & S03:23pmPO:P140 & 61 & A79 & Beard B & S35:19amPO:P244 & 32 & A157 & Bernasconi SM & S24:18pmPO:P215 & 31 & A582 \\
\hline Baker L & G08:21am03:C/S1 & 36 & A45 & Beard B & S41:23am09:A/Fm & 76 & A58 & Bernasconi SM & S30:18amPO:P256 & 31 & A769 \\
\hline Baker PA & $\mathrm{S} 24: 19 \mathrm{pm} 25: \mathrm{B} / \mathrm{Fo}$ & 21 & A203 & Beard B & $\mathrm{S} 41: 23 \mathrm{pm} 24: \mathrm{A} / \mathrm{Fm}$ & 81 & A371 & Bernasconi SM & S49:18pmPO:P108 & 34 & A801 \\
\hline Bakker RJ & G06:23pm24:C/S2 & 77 & A45 & Beard BL & G01:22am13:A/St & 46 & A431 & Bernasconi SM & S04:23amPO:P147 & 61 & A644 \\
\hline Balashov V & S18:22pmPO:P154 & 64 & A845 & Beaucaire C & S48:19pmPO:P353 & 34 & A179 & Bernasconi SM & $\mathrm{S} 28: 23 \mathrm{am} 08: \mathrm{B} / \mathrm{Fo}$ & 75 & A22 \\
\hline Balcaen L & S20:19am11:A/Co & 15 & A517 & Beccaluva L & S15:18am10:C/A1 & 4 & A90 & Bernatowicz TJ & $\mathrm{G} 01: 22 \mathrm{pm} 24: \mathrm{A} / \mathrm{St}$ & 51 & A507 \\
\hline Balco G & $\mathrm{S} 28: 22 \mathrm{pm} 31: \mathrm{B} / \mathrm{Fo}$ & 55 & A745 & Beccaluva L & S15:18am11:C/A1 & 4 & A149 & Berner RA & S25:21am02:B/Fo & 38 & A72 \\
\hline Baldini J & S28:23am14:B/Fo & 75 & A46 & Beccaluva L & S14:18pmPO:P002 & 29 & A59 & Berner U & S39:22pmPO:P359 & 70 & A771 \\
\hline Baldwin S & $\mathrm{S} 21: 21 \mathrm{pm} 24: \mathrm{A} / \mathrm{Co}$ & 44 & A235 & Beck P & G08:19pmPO:P155 & 25 & A59 & Berner UR & S39:22pmPO:P343 & 70 & A73 \\
\hline Baldwin SL & G01:22am03:A/St & 46 & A46 & Becker $\mathbf{H}$ & S02:18pm30:C/S1 & 7 & A60 & Berner UR & $\mathrm{S} 39: 22 \mathrm{pmPO}: \mathrm{P} 345$ & 70 & A161 \\
\hline Ball L & $\mathrm{S} 44: 18 \mathrm{pm} 24: \mathrm{A} / \mathrm{St}$ & 10 & A47 & Becker $\mathbf{L}$ & S04:23pm23:C/S1 & 78 & A61 & Bernstein S & S47:19pmPO:P314 & 33 & A 360 \\
\hline Ballentine C & $\mathrm{S} 40: 21 \mathrm{pm} 24: \mathrm{A} / \mathrm{Fm}$ & 45 & A878 & Becker ML & S45:19amPO:P030 & 33 & A60 & Berrodier I & $\mathrm{S} 37: 21 \mathrm{pm} 25: \mathrm{B} / \mathrm{Ja}$ & 45 & A223 \\
\hline Ballentine C & S10:22amPO:P137 & 62 & A797 & Becker ML & G04:22amPO:P245 & 57 & A556 & Berry A & G09:18pm25:A/Fm & 7 & A73 \\
\hline Ballentine $\mathrm{C}$ & $\mathrm{S} 10: 23 \mathrm{am} 02: \mathrm{C} / \mathrm{A} 1$ & 73 & A612 & Bedini $\mathrm{R}$ & $\mathrm{S} 11: 18 \mathrm{pm} 30: \mathrm{C} / \mathrm{A} 1$ & 8 & A633 & Bersina A & S17:23amPO:P012 & 63 & A729 \\
\hline Ballentine CJ & S10:23am04:C/A1 & 73 & A47 & Bedini RM & G01:19pmPO:P259 & 23 & A61 & Bertrand $\mathrm{H}$ & S11:18amPO:P050 & 27 & A625 \\
\hline Balykin P & S08:21pm26:C/A2 & 43 & A309 & Bedzyk M & G09:18pm26:A/Fm & 7 & A136 & Bertrand $\mathrm{H}$ & G05:21pm26:C/A1 & 41 & A133 \\
\hline Banerjee D & S48:18pm30:B/Ja & 11 & A48 & Beer J & S28:22amPO:P218 & 67 & A538 & Besmehn A & S01:19amPO:P145 & 26 & A528 \\
\hline Banerjee NR & S33:18am09:B/Pi & 4 & A48 & Beets C & S44:18am12:A/St & 5 & A812 & Bessonov D & S17:22am13:C/A2 & 47 & A74 \\
\hline Banfield J & S22:23pm25:A/Co & 79 & A49 & Beets CJ & S28:22amPO:P215 & 67 & A62 & Bessonova $\mathrm{E}$ & G07:18pmPO:P321 & 24 & A74 \\
\hline Bar-Matthews M & S45:18pm30:A/Co & 11 & A377 & Beets DJ & S28:22amPO:P215 & 67 & A62 & Beuchat S & S17:22pm29:C/A2 & 53 & A75 \\
\hline Bar-Matthews M & $\mathrm{S} 49: 19 \mathrm{pm} 30: \mathrm{A} / \mathrm{Fm}$ & 22 & A436 & Behrends T & S48:19am03:B/Ja & 17 & A62 & Beveridge TJ & G04:23am10:B/Pi & 72 & A276 \\
\hline Bar-Matthews M & S44:19amPO:P296 & 33 & A209 & Behrends T & S48:19pmPO:P352 & 34 & A143 & Beyer EE & G08:21pm21:C/S1 & 42 & A75 \\
\hline Bar-Matthews M & G03:21pm23:B/Fo & 41 & A14 & Behrensmeyer K & S29:19pm25:A/St & 21 & A786 & Beyerle U & $\mathrm{S} 40: 21 \mathrm{pm} 26: \mathrm{A} / \mathrm{Fm}$ & 45 & A8 \\
\hline Bar-Matthews M & G03:21pm28:B/Fo & 41 & A500 & Beig M & S48:18am05:B/Ja & 6 & A63 & Beyerle U & S31:22pm21:A/Co & 55 & A445 \\
\hline Bar-Matthews M & $\mathrm{S} 31: 22 \mathrm{pm} 23: \mathrm{A} / \mathrm{Co}$ & 55 & A266 & Beig MS & S48:19pmPO:P362 & 34 & A465 & Bhandari N & S04:23amPO:P148 & 61 & A712 \\
\hline Bar-Matthews M & S26:23amPO:P202 & 66 & A49 & Beja O & $\mathrm{S35:21pm23:B/Pi}$ & 44 & A63 & Bhaskar Rao Y & S20:18pmPO:P028 & 30 & A793 \\
\hline Bar-Matthews M & S28:23pm27:B/Fo & 80 & A39 & Bekker A & S07:18pm24:C/S2 & 8 & A64 & Bhaskar Rao Y & G01:19pmPO:P258 & 23 & A860 \\
\hline Bar-Nun A & S05:19pm23:C/S2 & 19 & A50 & Bekker A & S07:18pm26:C/S2 & 8 & A840 & Bhattacharya S & S20:18pmPO:P025 & 30 & A76 \\
\hline Barabash N & S20:19pm28:A/Co & 20 & A791 & Bell DB & S15:18am07:C/A1 & 4 & A290 & Bi X & G09:18am04:A/Fm & 2 & A76 \\
\hline Baranova N & S18:21pm27:C/S2 & 43 & A50 & Bell K & G05:21am01:C/A1 & 36 & A776 & Bi $X$ & G09:18am01:A/Fm & 2 & A344 \\
\hline Baranova N & $\mathrm{S} 18: 21 \mathrm{pm} 29: \mathrm{C} / \mathrm{S} 2$ & 43 & A760 & Bell KR & S02:19pm29:C/S1 & 18 & A64 & Bi X & S11:18amPO:P054 & 27 & A749 \\
\hline Barbarand $\mathrm{J}$ & S45:18pm23:A/Co & 11 & A314 & Belle Jv & S44:18am12:A/St & 5 & A812 & Bianchini G & S14:18pmPO:P002 & 29 & A59 \\
\hline Barbier B & S05:19pm31:C/S2 & 19 & A505 & Bellieni G & G05:22pmPO:P042 & 58 & A188 & Bianchini G & $\mathrm{S} 38: 22 \mathrm{pm} 29: \mathrm{B} / \mathrm{Ja}$ & 56 & A589 \\
\hline Barcala JM & G10:22pmPO:P278 & 60 & A694 & Bellieni G & G05:22pmPO:P065 & 58 & A729 & Bickford M & G01:22am12:A/St & 46 & A144 \\
\hline Barfod DN & S21:21pm28:A/Co & 44 & A51 & Bellier O & S46:22pmPO:P271 & 71 & A714 & Bickle MJ & S07:19pmPO:P166 & 27 & A129 \\
\hline Barfod GH & S45:18am14:A/Co & 6 & A51 & Bellomo S & G05:21pm28:C/A1 & 41 & A65 & Bickle MJ & S22:23am03:A/Co & 74 & A77 \\
\hline Bargar J & $\mathrm{S} 48: 19 \mathrm{am} 07: \mathrm{B} / \mathrm{Ja}$ & 17 & A95 & Belousova E & G01:19pmPO:P260 & 23 & A89 & Bierman P & S21:21am11:A/Co & 38 & A77 \\
\hline Barkan E & S42:18am14:B/Fo & 5 & A466 & Belshaw N & S02:19am07:C/S1 & 12 & A33 & Biester H & $\mathrm{S} 32: 18 \mathrm{pm} 27: \mathrm{B} / \mathrm{Pi}$ & 10 & A395 \\
\hline Barker D & S22:23am10:A/Co & 74 & A 322 & Belshaw N & S24:19am14:B/Fo & 15 & A485 & Bilodeau G & S25:22amPO:P211 & 66 & A171 \\
\hline Barling J & $\mathrm{S} 41: 22 \mathrm{pm} 29: \mathrm{A} / \mathrm{Fm}$ & 56 & A30 & Belshaw N & $\mathrm{S} 41: 22 \mathrm{pm} 24: \mathrm{A} / \mathrm{Fm}$ & 56 & A129 & Bindeman I & S14:18pmPO:P009 & 29 & A611 \\
\hline Barling J & S41:22pm28:A/Fm & 56 & A52 & Belshaw N & $\mathrm{S} 41: 23 \mathrm{am} 03: \mathrm{A} / \mathrm{Fm}$ & 76 & A298 & Bindeman IN & S16:23pm26:C/A2 & 79 & A78 \\
\hline Barmettler K & G07:19pm24:B/Ja & 18 & A417 & Belshaw NS & S45:19amPO:P030 & 33 & A60 & Bingen B & S45:18am08:A/Co & 6 & A78 \\
\hline Barmettler K & $\mathrm{S} 37: 21 \mathrm{am} 06: \mathrm{B} / \mathrm{Ja}$ & 39 & A293 & Belshaw NS & S44:19amPO:P294 & 33 & A65 & Binns R & $\mathrm{S} 17: 22 \mathrm{pm} 30: \mathrm{C} / \mathrm{A} 2$ & 53 & A41 \\
\hline Barmina GS & S16:22pmPO:P022 & 63 & A52 & Beltenev V & S10:22amPO:P117 & 62 & A66 & Birck J & S03:23am10:C/S1 & 73 & A120 \\
\hline Barnes H & $\mathrm{S} 18: 21 \mathrm{am} 07: \mathrm{C} / \mathrm{S} 2$ & 37 & A467 & Belton D & $\mathrm{S} 21: 21 \mathrm{pm} 22: \mathrm{A} / \mathrm{Co}$ & 44 & A106 & Bird DK & S05:18pmPO:P163 & 27 & A447 \\
\hline Barnes S & S08:21am03:C/A2 & 37 & A53 & Belyatsky B & S11:18amPO:P055 & 27 & A754 & Birkefeld A & S48:19pmPO:P351 & 34 & A79 \\
\hline Barnes S & S08:22pmPO:P016 & 61 & A195 & Belyatsky B & S10:22amPO:P117 & 62 & A66 & Biscaye PE & $\mathrm{S} 27: 22 \mathrm{am} 12: \mathrm{B} / \mathrm{Fo}$ & 48 & A92 \\
\hline Barnes S & S08:22pmPO:P017 & 61 & A 328 & Ben Othman D & S41:23am01:A/Fm & 76 & A462 & Bischoff A & S02:19pm26:C/S1 & 18 & A844 \\
\hline Baron D & G04:23pm27:B/Pi & 77 & A515 & Bender Koch C & G07:18pmPO:P338 & 25 & A477 & Bischoff A & $\mathrm{S} 40: 21 \mathrm{am} 08: \mathrm{A} / \mathrm{Fm}$ & 40 & A809 \\
\hline Baroni C & $\mathrm{S} 28: 22 \mathrm{pm} 32: \mathrm{B} / \mathrm{Fo}$ & 55 & A565 & Bendtsen J & $\mathrm{S} 04: 23 \mathrm{pm} 27: \mathrm{C} / \mathrm{S} 1$ & 78 & A66 & Bischoff A & S03:22pm28:C/S1 & 52 & A404 \\
\hline Baroux E & S46:22pmPO:P271 & 71 & A714 & Benedetti M & G07:19pm23:B/Ja & 18 & A374 & Bischoff JL & S05:18pmPO:P163 & 27 & A447 \\
\hline Barrat J & G08:19pmPO:P155 & 25 & A59 & Benedetti M & G07:18pmPO:P324 & 24 & A123 & Bishop P & $\mathrm{S} 21: 21 \mathrm{pm} 29: \mathrm{A} / \mathrm{Co}$ & 44 & A593 \\
\hline Barriga $F$ & $\mathrm{~S} 17: 22 \mathrm{pm} 30: \mathrm{C} / \mathrm{A} 2$ & 53 & A41 & Benedetti M & G07:18pmPO:P342 & 25 & A612 & Bitinas A & S28:22amPO:P219 & 67 & A640 \\
\hline Barry T & $\mathrm{S} 40: 22 \mathrm{am} 06: \mathrm{A} / \mathrm{Fm}$ & 50 & A 312 & Benedetti M & $\mathrm{S} 37: 21 \mathrm{pm} 25: \mathrm{B} / \mathrm{Ja}$ & 45 & A223 & Bizimis M & $\mathrm{S} 10: 23 \mathrm{am} 12: \mathrm{C} / \mathrm{A} 1$ & 73 & A360 \\
\hline Barry $\mathrm{T}$ & S10:22amPO:P115 & 62 & A53 & Benedetti MF & S37:21pm24:B/Ja & 45 & A67 & Bizzaro M & S44:19amPO:P304 & 33 & A792 \\
\hline Barsczus HG & S09:22am05:C/A1 & 47 & A85 & Bénédicte M & S42:19amPO:P222 & 32 & A364 & Bizzarro M & S08:21am12:C/A2 & 37 & A741 \\
\hline Barth MG & S11:19pm29:C/A1 & 19 & A54 & Beney P & S42:19amPO:P220 & 32 & A67 & Bizzarro M & S03:23pmPO:P140 & 61 & A79 \\
\hline Barton M & $\mathrm{S} 17: 22 \mathrm{pm} 27: \mathrm{C} / \mathrm{A} 2$ & 53 & A507 & Benner S & $\mathrm{S} 48: 19 \mathrm{am} 01: \mathrm{B} / \mathrm{Ja}$ & 17 & A229 & Bjerg PL & S38:22pm21:B/Ja & 56 & A80 \\
\hline Basile-Doelsch I & $\mathrm{S} 27: 22 \mathrm{am} 14: \mathrm{B} / \mathrm{Fo}$ & 48 & A175 & Benner S & $\mathrm{S} 36: 21 \mathrm{pm} 28: \mathrm{B} / \mathrm{Pi}$ & 44 & A553 & Bjerrum CJ & S07:18am06:C/S2 & 3 & A80 \\
\hline Bassett WA & $\mathrm{S} 18: 21 \mathrm{am} 11: \mathrm{C} / \mathrm{S} 2$ & 37 & A496 & Bennett B & $\mathrm{S} 34: 22 \mathrm{am} 05: \mathrm{B} / \mathrm{Ja}$ & 49 & A25 & Bjerrum CJ & S04:23pm27:C/S1 & 78 & A66 \\
\hline Bastow T & $\mathrm{S} 34: 22 \mathrm{am} 07: \mathrm{B} / \mathrm{Ja}$ & 49 & A794 & Bennett V & S06:19am16:C/S2 & 13 & $\mathrm{~A} 312$ & Black J & S18:21pm25:C/S2 & 43 & A81 \\
\hline Bastrakov E & S17:23amPO:P001 & 63 & A54 & Bennett V & S14:19am06:C/A2 & 14 & A754 & Blacklock KA & $\mathrm{G} 01: 22 \mathrm{am} 05: \mathrm{A} / \mathrm{St}$ & 46 & A158 \\
\hline Batanova V & G05:22pmPO:P061 & 58 & A593 & Bennett V & S03:23am12:C/S1 & 73 & A68 & Blake R & $\mathrm{S} 33: 18 \mathrm{am} 01: \mathrm{B} / \mathrm{Pi}$ & 4 & A163 \\
\hline Batanova V & S10:22amPO:P116 & 62 & A55 & Benning L & $\mathrm{S} 37: 21 \mathrm{pm} 32: \mathrm{B} / \mathrm{Ja}$ & 45 & A862 & Blake S & S16:22pmPO:P035 & 63 & A839 \\
\hline Batt GE & $\mathrm{G} 01: 22 \mathrm{am} 03: \mathrm{A} / \mathrm{St}$ & 46 & A46 & Benning 1 & $\mathrm{G} 04: 23 \mathrm{am} 02: \mathrm{B} / \mathrm{Pi}$ & 72 & A529 & Blake $\mathbf{S}$ & S16:23pm30:C/A2 & 79 & A81 \\
\hline Batt GE & S21:22pmPO:P284 & 65 & A55 & Benning LG & S48:19am04:B/Ja & 17 & A68 & Blake S & $\mathrm{S} 16: 23 \mathrm{pm} 22: \mathrm{C} / \mathrm{A} 2$ & 79 & A525 \\
\hline Battisti D & S28:23pm21:B/Fo & 80 & A56 & Benning LG & $\mathrm{S} 37: 21 \mathrm{am} 14: \mathrm{B} / \mathrm{Ja}$ & 39 & A17 & Blake S & $\mathrm{S} 16: 23 \mathrm{pm} 28: \mathrm{C} / \mathrm{A} 2$ & 79 & A772 \\
\hline Bau M & S07:19pmPO:P172 & 27 & A742 & Benning LG & $\mathrm{S} 37: 21 \mathrm{am} 13: \mathrm{B} / \mathrm{Ja}$ & 39 & A704 & Bland PA & S02:18pm27:C/S1 & 7 & A11 \\
\hline Baublys KA & $\mathrm{S} 04: 23 \mathrm{pm} 28: \mathrm{C} / \mathrm{S} 1$ & 78 & A283 & Bentov $\mathrm{S}$ & $\mathrm{S} 49: 19 \mathrm{am} 07: \mathrm{A} / \mathrm{Fm}$ & 17 & A216 & Blencoe $\mathbf{J}$ & S18:21am03:C/S2 & 37 & A82 \\
\hline Baudenbacher F & S03:23am14:C/S1 & 73 & A827 & Benz W & S02:19pm22:C/S1 & 18 & A69 & Blichert-Toft J & G01:19pmPO:P259 & 23 & A61 \\
\hline Baumgartner L & G06:23am11:C/S2 & 72 & A842 & Benz W & S02:18amPO:P150 & 26 & A258 & Blichert-Toft $\mathrm{J}$ & G05:21am05:C/A1 & 36 & A255 \\
\hline Baumgartner LP & G01:22am13:A/St & 46 & A 431 & Benzerara $\mathbf{K}$ & $\mathrm{S35:21am10:B/Pi}$ & 39 & A69 & Blichert-Toft $\mathrm{J}$ & G05:21am06:C/A1 & 36 & A550 \\
\hline Baumgartner M & $\mathrm{S} 35: 21 \mathrm{am} 09: \mathrm{B} / \mathrm{Pi}$ & 39 & A752 & Beresford S & S08:21am02:C/A2 & 37 & A122 & Blichert-Toft J & S03:22am07:C/S1 & 46 & A11 \\
\hline Baur $\mathrm{H}$ & $\mathrm{S} 44: 18 \mathrm{am} 10: \mathrm{A} / \mathrm{St}$ & 5 & A 303 & Beresford S & S08:22pmPO:P015 & 61 & A70 & Blichert-Toft J & S03:22am11:C/S1 & 46 & A82 \\
\hline Baur H & $\mathrm{S} 40: 21 \mathrm{am} 09: \mathrm{A} / \mathrm{Fm}$ & 40 & A112 & Berg M & $\mathrm{S} 38: 22 \mathrm{pm} 27: \mathrm{B} / \mathrm{Ja}$ & 56 & A883 & Blichert-Toft J & $\mathrm{S} 03: 22 \mathrm{pm} 29: \mathrm{C} / \mathrm{S} 1$ & 52 & A863 \\
\hline Baur $\mathrm{H}$ & $\mathrm{S} 40: 21 \mathrm{am} 08: \mathrm{A} / \mathrm{Fm}$ & 40 & A809 & Berg P & S07:18pm21:C/S2 & 8 & A118 & Blichert-Toft J & S10:22amPO:P112 & 62 & A9 \\
\hline Baur H & $\mathrm{S} 28: 22 \mathrm{pm} 32: \mathrm{B} / \mathrm{Fo}$ & 55 & A565 & Berg U & G04:22amPO:P231 & 57 & A70 & Blichert-Toft $\mathrm{J}$ & S10:22amPO:P113 & 62 & A22 \\
\hline Baur I & S39:23pm24:B/Ja & 80 & A56 & Berger A & G06:23am12:C/S2 & 72 & A71 & Blichert-Toft J & S10:22amPO:P129 & 62 & A478 \\
\hline Baur I & $\mathrm{S} 39: 23 \mathrm{pm} 23: \mathrm{B} / \mathrm{Ja}$ & 80 & A369 & Berly $T$ & S13:18am13:C/A2 & 3 & A71 & Blichert Toft $\mathrm{J}$ & G05:22pmPO:P038 & 58 & A29 \\
\hline Baxter E & S20:19pm23:A/Co & 20 & A57 & Bermanec V & G09:19amPO:P116 & 25 & A366 & Blodau C & S30:19am14:B/Pi & 16 & A83 \\
\hline Bayon G & S27:22am10:B/Fo & 48 & A57 & Bernal JP & S44:18pm26:A/St & 10 & A72 & Blowes D & S19:22am11:C/S2 & 48 & A496 \\
\hline Bazin D & S37:21nm 27:B/Ja & 45 & A58 & Bernasconis & $\mathrm{S} 25 \cdot 21 \mathrm{am} 06 \cdot \mathrm{B} / \mathrm{Fo}$ & 38 & A107 & Blowes DW & $\mathrm{S} 30 \cdot 19 \mathrm{am} 13 \cdot \mathrm{B} / \mathrm{Pi}$ & 16 & \\
\hline
\end{tabular}


Goldschmidt 2002 Index

Author

Blum J

Blum JD

Blumenberg M

Blundy J

Blundy J

Blundy J

Blundy J

Blundy J

Blundy JD

Blundy JD

Boaretto E

Bocherens $\mathbf{H}$

Bock B

Bock B

Boctor N

Boctor $\mathrm{N}$

Bodinier J

Bodinier J

Bodnar R

Bodnar RJ

Boehler R

Boerema J

Boering K

Boetius A

Boetius A

Boettcher ME

Bogatikov O

Bohlin $\mathrm{H}$

Böhm F

Böhm F

Bohrson W

Boily J

Boily J

Boivin P

Bojakowska I

Bollmann J

Bomparola RM

Bonadiman C

Bonadiman C

Bonhoure I

Bonli T

Bonnin-Mosbah M

Bonotto DM

Bopp L

Bordeanu C

Boreham C

Borgendahl J

Borisenko A

Borisenko A

Borkovec M

Borovikov A

Borovikov A

Borsato A

Bory AJ

Bosak T

Bosbach D

Bosbach D

Bosbach D

Boschi C

Bosselmann K

Bostick B

Bostick B

Botta O

Böttcher ME

Bottinelli M

Bottrell S

Boudou A

Boudou A

Bouhedja M

Bouikine A

Boullier A

Bouman C

Bourdon $\mathrm{B}$

Bourdon B

Bourdon B

Bourles D

Bourlès D

Bourlès DL

Bourlès DL

Bourot-Denise M

Bowen D

Bowman J

Bowman JR
Code

S27:23amPO:P223

$\mathrm{S} 44: 18 \mathrm{am} 14: \mathrm{A} / \mathrm{St}$

S35:21 am07:B/Pi

S15:18am02:C/A1

S11:19pm26:C/A1

S15:19amPO:P065

S16:23am01:C/A2

S16:23pm23:C/A2

S15:18am01:C/A1

S14:19am14:C/A2

$\mathrm{S} 29: 19 \mathrm{pm} 26: \mathrm{A} / \mathrm{St}$

S29:19pm24:A/St

S24:19am09:B/Fo

S22:22amPO:P301

S43:21am07:A/St

S34:23amPO:P314

S11:19am07:C/A

S09:22am05:C/A1

S17:22pm23:C/A2

S17:22pm21:C/A2

S10:23am08:C/A1

G04:23am02:B/Pi

S43:21am03:A/St

S35:19amPO:P245

$\mathrm{S} 35: 21 \mathrm{am} 04: \mathrm{B} / \mathrm{P}$

G04:22amPO:P233

S03:23pmPO:P144

G07:18pmPO:P322

S24:19am13:B/Fo

S24:19am09:B/Fo

S16:23am05:C/A2

G09:19amPO:P110

$\mathrm{S} 37: 21 \mathrm{pm} 31: \mathrm{B} / \mathrm{Ja}$

S48:18pm31:B/Ja

G07:18pmPO:P323

S24:19pm32:B/Fo

G01:19pmPO:P260

S15:18am10:C/A1

S15:18am11:C/A1

S39:23pm25:B/Ja

S47:19pmPO:P318

S17:22am11:C/A2

S31:22am11:A/Co

S23:18pm27:B/Fo

$\mathrm{S} 29: 19 \mathrm{pm} 26: \mathrm{A} / \mathrm{St}$

S43:21am04:A/St

G04:22amPO:P232

G10:22pmPO:P277

S18:22pmPO:P152

S37:21 am06:B/Ja

G10:22pmPO:P277

S18:22pmPO:P152

G08:19pmPO:P156

S27:22am12:B/Fo

S07:18am13:C/S2

G07:18pmPO:P325

S39:22pmPO:P344

S39:22pmPO:P344

G06:22pmPO:P163

G04:22amPO:P233

S48:19am07:B/Ja

$\mathrm{S} 48: 19 \mathrm{am} 01: \mathrm{B} / \mathrm{Ja}$

S01:18am12:C/S1

G04:22amPO:P234

S30:18amPO:P255

G08:21am14:C/S1

G04:23am03:B/Pi

G04:23am04:B/Pi

S11:18amPO:P045

S40:22am 13:A/Fm

G06:23am04:C/S2

S44:18am11:A/St

S14:19am05:C/A2

S21:21am05:A/Co

S03:23am 10:C/S 1

S46:23am08:A/St

S46:23pm27:A/St

$\mathrm{S} 46: 23 \mathrm{pm} 24: \mathrm{A} / \mathrm{St}$

S46:23pm29:A/St

S02:19am12:C/S

$\mathrm{S} 28: 22 \mathrm{pm} 29: \mathrm{B} / \mathrm{Fo}$

G06:23am09:C/S2

G06:22pmPO:P176

Prog. Abs. Author

Bown P

A105 Boyet M

1984 Boyet $M$

29 A499 Boyet M

$\begin{array}{lll}7483 & \text { Boyet } M\end{array}$

79 A23 Boztug D

4 A846 Brabson E

A405 Brack A

21 A805 Bracke G

21 A84 Bradbury M

5 A211 Bradley J

65 A456 Brady E

40 A85 Brandes J

68 A147 Brandon A

14 A281 Brandon AD

47 A85 Brandon AD

53 A86 Brandon M

53 A37 Brantley S

A86 Brantley S

72 A529 Brantley S

40 A622 Brantley S

32 A407 Brantley SL

39 A214 Brantley SL

57 A94 Brasier M

61 A702 Brassell S

24 A87 Braucher R

15 A87 $\quad$ Braucher R

15 A211 Braucher $\mathbf{R}$

74 A88 Brauns M

A88 Breddam $\mathbf{K}$

45 A227 Breedveld G

11 A226 Brenan J

24 A89 Brennwald MS

$21 \quad \mathrm{~A} 680$

23 A89

$4 \quad \mathbf{A 9 0}$

4 A149

$80 \mathbf{A 9 0}$

33 A741

47 A508

49 A91

9 A91

21 A805

$40 \quad \mathrm{~A} 697$

$57 \quad$ A92

$60 \quad A$

39 A293

60 A

$64 \quad$ A547

$25 \quad$ A247

$48 \quad$ A92

$3 \quad \mathbf{A 9 3}$

24 A130

70 A93

70 A93

59 A94

57 A94

$17 \quad \mathbf{A 9 5}$

17 A229

2 A208

$57 \quad$ A95

31 A663

36 A145

$72 \quad \mathrm{~A} 13$

72 A609

$27 \quad$ A96

50 A96

72 A646

5 A97

14 A193

$\begin{array}{ll}38 & \text { A97 }\end{array}$

73 A120

$76 \quad$ A267

81 A98

81 A102

$81 \quad$ A119

12 A869

55 A598

72 $\mathbf{A 9 8}$

Brewer $\mathrm{T}$

Bridges J

Bröcker M

Broecker W

Broecker W

Brooker R

Brooker R

Brouwer FM

Brown A

Brown C

Brown E

Brown G

Brown GE

Brown Jr GE

Brown Jr. GE

Brown R

Brown R

Brown RW

Brown T

Brown, Jr. GE

Browning L

Brownlee C

Brownlee D

Brüchert V

Bruegmann $\mathrm{G}$

Brügmann GE

Brukner-Wein A

Brumme R

Brumsack $\mathrm{H}$

Brumsack H

Brunner B

Bryce J

Brzezinski MA

Büchl A

Büchl A

Büchl A

Buerge-Weirich D

Buffat P

Buhre S

Bullen T 
Goldschmidt 2002 Index

\begin{tabular}{|c|c|c|c|c|c|c|c|c|c|c|c|}
\hline Author & Code & Prog. & Abs. & Author & Code & Prog. & Abs. & Author & Code & Prog. & Abs. \\
\hline Carosi R & S20:18pmPO:P026 & 30 & A121 & Chen F & G05:22pmPO:P064 & 58 & A714 & Colin S & S38:23amPO:P335 & 69 & A345 \\
\hline Carrera J & S19:23amPO:P161 & 64 & A483 & Chen $\mathrm{H}$ & $\mathrm{S} 41: 23 \mathrm{am} 02: \mathrm{A} / \mathrm{Fm}$ & 76 & A135 & Collerson K & S07:18am03:C/S2 & 3 & A684 \\
\hline Carrez P & S02:19am01:C/S1 & 12 & A300 & Chen J & G09:18am11:A/Fm & 2 & A135 & Collerson K & S09:22am09:C/A1 & 47 & A148 \\
\hline Carter A & $\mathrm{S} 45: 18 \mathrm{pm} 23: \mathrm{A} / \mathrm{Co}$ & 11 & A314 & Chen J & G03:19pmPO:P226 & 24 & A134 & Collerson K & S09:22am10:C/A1 & 47 & A379 \\
\hline Cartigny P & S13:18am07:C/A2 & 3 & A113 & Chen J & G03:19pmPO:P236 & 24 & A763 & Collerson K & S10:23am13:C/A1 & 73 & A538 \\
\hline Cartigny $P$ & S12:18pm29:C/A2 & 9 & A121 & Chen J & S13:19amPO:P020 & 28 & A862 & Collinson M & G03:21pm30:B/Fo & 41 & A 493 \\
\hline Cartigny $\mathrm{P}$ & S12:19pmPO:P035 & 28 & $\mathrm{~A} 420$ & Chen Y & S13:19amPO:P020 & 28 & A862 & Coltelli M & $\mathrm{G} 05: 21 \mathrm{pm} 28: \mathrm{C} / \mathrm{A} 1$ & 41 & $\mathrm{~A} 65$ \\
\hline Cartledge $\mathrm{F}$ & $\mathrm{S} 39: 23 \mathrm{pm} 27: \mathrm{B} / \mathrm{Ja}$ & 80 & A209 & Chen Y & S10:22amPO:P131 & 62 & A559 & Coltorti M & S15:18am10:C/A1 & 4 & A90 \\
\hline Caruso A & $\mathrm{S} 49: 19 \mathrm{pm} 29: \mathrm{A} / \mathrm{Fm}$ & 22 & A236 & Chenery C & $\mathrm{S} 29: 19 \mathrm{pm} 21: \mathrm{A} / \mathrm{St}$ & 21 & A109 & Coltorti M & S15:18am11:C/A1 & 4 & A149 \\
\hline Cas $\mathbf{R}$ & S08:21am02:C/A2 & 37 & $\mathbf{A 1 2 2}$ & Cheney JT & S20:19am04:A/Co & 15 & A730 & Coltorti M & S14:18pmPO:P002 & 29 & A59 \\
\hline Cas R & S08:22pmPO:P015 & 61 & A70 & Cheng $\mathrm{H}$ & $\mathrm{S} 16: 23 \mathrm{am} 11: \mathrm{C} / \mathrm{A} 2$ & 74 & A35 & Coltorti M & S16:22pmPO:P030 & 63 & A486 \\
\hline Cas $\mathrm{R}$ & S08:22pmPO:P020 & 61 & A785 & Cheng L & G09:18pm26:A/Fm & 7 & A136 & Combes R & S09:22am04:C/A1 & 47 & A715 \\
\hline Casanova J & $\mathrm{S} 22: 22 \mathrm{pm} 32: \mathrm{A} / \mathrm{Co}$ & 54 & A595 & Chengming Z & S17:23amPO:P014 & 63 & A876 & Conceição H & G01:19pmPO:P278 & 23 & A647 \\
\hline Casey B & S37:21pm29:B/Ja & 45 & A122 & Cheong C & G01:19pmPO:P263 & 23 & A137 & Conceição H & G05:21 am14:C/A1 & 36 & A149 \\
\hline Casey W & $\mathrm{S} 48: 18 \mathrm{pm} 29: \mathrm{B} / \mathrm{Ja}$ & 11 & A250 & Cheong $\mathrm{C}$ & G01:19pmPO:P280 & 23 & A661 & Conceição H & $\mathrm{G} 01: 22 \mathrm{pm} 27: \mathrm{A} / \mathrm{St}$ & 51 & A640 \\
\hline Cashman K & S16:23am01:C/A2 & 74 & A83 & Cheong $\mathrm{C}$ & S10:22amPO:P119 & 62 & A139 & Conceição RV & G05:21am14:C/A1 & 36 & A149 \\
\hline Casiot C & $\mathrm{S} 48: 18 \mathrm{pm} 25: \mathrm{B} / \mathrm{Ja}$ & 11 & A526 & Cherneva Z & G01:19pmPO:P276 & 23 & A573 & Conceição RV & G05:21am15:C/A1 & 36 & A607 \\
\hline Castillo P & $\mathrm{G} 05: 21 \mathrm{pm} 32: \mathrm{C} / \mathrm{A} 1$ & 41 & A767 & Cherniak D & S11:18pm26:C/A1 & 8 & A254 & Conforto L & G07:18pmPO:P339 & 25 & A479 \\
\hline Castillo PR & S14:19am08:C/A2 & 14 & $\mathbf{A 1 2 3}$ & Chesley J & S14:19pm26:C/A2 & 20 & A137 & Connolly J & S13:18am01:C/A2 & 3 & A396 \\
\hline Castrec-Rouelle M & G07:18pmPO:P324 & 24 & A123 & Chesley J & G01:22pm22:A/St & 51 & A400 & Conrad P & S48:18am07:B/Ja & 6 & A150 \\
\hline Castro MC & S31:22am14:A/Co & 49 & A124 & Chesseman C & $\mathrm{S} 48: 18 \mathrm{pm} 22: \mathrm{B} / \mathrm{Ja}$ & 11 & A676 & Cooke D & S17:23amPO:P002 & 63 & A169 \\
\hline Cathles LM & S34:22am11:B/Ja & 49 & A124 & Chialvo A & $\mathrm{S} 37: 21 \mathrm{pm} 21: \mathrm{B} / \mathrm{Ja}$ & 45 & A160 & Cooke DJ & G10:21pm23:A/St & 42 & A150 \\
\hline Causse C & S22:22amPO:P306 & 65 & A602 & Chiaradia M & S14:18pmPO:P003 & 29 & A138 & Cooper C & S48:19am05:B/Ja & 17 & A151 \\
\hline Cave RR & S42:18am09:B/Fo & 5 & A132 & Chien Y & G09:19amPO:P111 & 25 & A138 & Cooper E & S48:19pmPO:P364 & 34 & A801 \\
\hline Cavosie A & S07:18am04:C/S2 & $\mathbf{3}$ & A125 & Chikaraishi Y & S43:22pmPO:P266 & 71 & A139 & Cooper K & S16:23am10:C/A2 & 74 & A284 \\
\hline Cavosie A & S03:23am07:C/S1 & 73 & A794 & Chillrud SN & S31:22am06:A/Co & 49 & A749 & Cooper K & S10:23pm26:C/A1 & 78 & A151 \\
\hline Cawood P & G01:22pm28:A/St & 51 & A201 & Ching J & S39:22pmPO:P353 & 70 & A519 & Corbella M & S19:23amPO:P156 & 64 & A152 \\
\hline Cayzer N & S45:18am04:A/Co & 6 & A441 & Chiodini G & S12:18pm21:C/A2 & 9 & A829 & Corcho Alvarado JA & S31:23amPO:P281 & 67 & A152 \\
\hline Celik F & G01:19pmPO:P262 & 23 & A125 & Choi M & G01:19pmPO:P263 & 23 & A137 & Cordier P & S02:19am01:C/S1 & 12 & A 300 \\
\hline Cennamo P & G04:22amPO:P235 & 57 & A126 & Choi SH & S10:22amPO:P119 & 62 & A139 & Corfu F & G01:19pmPO:P288 & 23 & A786 \\
\hline Censi P & S44:19amPO:P302 & 33 & A617 & Choo CO & G09:19amPO:P112 & 25 & A140 & Corfu F & G01:22am10:A/St & 46 & A153 \\
\hline Cerbai $\mathrm{N}$ & S38:22pm29:B/Ja & 56 & A589 & Choo CO & G07:18pmPO:P337 & 25 & A443 & Corgne A & S03:22am06:C/S1 & 46 & A153 \\
\hline Cervantes P & S14:19am09:C/A2 & 14 & A126 & Chorover J & S48:19pmPO:P367 & 34 & A882 & Corrége $\mathrm{O}$ & G07:19am09:B/Ja & 12 & A569 \\
\hline Cervini-Silva J & S36:22am05:B/Pi & 50 & A127 & Chou I & S18:21am11:C/S2 & 37 & A496 & Cosca M & S20:19am13:A/Co & 15 & A154 \\
\hline Chabaux F & S21:22pmPO:P285 & 65 & A177 & Christenson B & $\mathrm{S} 18: 21 \mathrm{pm} 30: \mathrm{C} / \mathrm{S} 2$ & 43 & A530 & Cosca M & G06:22pmPO:P167 & 59 & A274 \\
\hline Chabaux F & S22:22amPO:P294 & 65 & A202 & Christiansen BC & S37:23amPO:P326 & 69 & A140 & Cosca MA & S20:19am14:A/Co & 15 & A532 \\
\hline Chabaux F & S22:22amPO:P306 & 65 & A602 & Christiansen $\mathrm{H}$ & S46:23am09:A/St & 76 & A748 & Cosca MA & S20:19pm24:A/Co & 20 & A416 \\
\hline Chabaux F & S22:23am09:A/Co & 74 & A127 & Christie-Blick N & S07:19am08:C/S2 & 13 & A394 & Costa F & S16:22pmPO:P023 & 63 & A154 \\
\hline Chabaux F & S22:23am08:A/Co & 74 & A641 & Christl I & S37:21am11:B/Ja & 39 & A317 & Costa F & $\mathrm{S} 16: 23 \mathrm{pm} 21: \mathrm{C} / \mathrm{A} 2$ & 79 & A128 \\
\hline Chadwick O & S21:21am03:A/Co & 38 & A128 & Christl M & S23:19pmPO:P202 & 30 & A141 & Cottin J & S15:19amPO:P059 & 29 & A155 \\
\hline Chadwick O & S22:23am13:A/Co & 74 & A346 & Christl M & S30:18amPO:P253 & 31 & A434 & Cottin $\mathrm{J}$ & G05:21am16:C/A1 & 36 & A176 \\
\hline Chadwick OA & $\mathrm{S} 22: 23 \mathrm{pm} 24: \mathrm{A} / \mathrm{Co}$ & 79 & A881 & Christof O & S32:18pm28:B/Pi & 10 & A141 & Coussaert N & S10:22amPO:P120 & 62 & A155 \\
\hline Chae B & S15:19amPO:P063 & 29 & A441 & Chu N & S42:18am06:B/Fo & 5 & A142 & Cowdery S & $\mathrm{S} 28: 22 \mathrm{pm} 31: \mathrm{B} / \mathrm{Fo}$ & 55 & A745 \\
\hline Chakraborty $S$ & S16:23pm21:C/A2 & 79 & A128 & Chung J & G07:18pmPO:P336 & 25 & A440 & Cowen J & $\mathrm{S} 34: 22 \mathrm{am} 13: \mathrm{B} / \mathrm{Ja}$ & 49 & A393 \\
\hline Chamberlain CP & S09:22am07:C/A1 & 47 & A504 & Chung S & G01:19pmPO:P273 & 23 & A429 & Cox JS & S34:22am15:B/Ja & 49 & A156 \\
\hline Chamorro E & S15:18am02:C/A1 & 4 & A105 & Cingolani CA & S11:18pm29:C/A1 & 8 & A143 & Cox S & G06:23am04:C/S2 & 72 & A646 \\
\hline Chan L & S13:19amPO:P019 & 28 & A670 & Ciniglia C & G04:22amPO:P235 & 57 & A126 & Crannell B & $\mathrm{S} 39: 23 \mathrm{pm} 27: \mathrm{B} / \mathrm{Ja}$ & 80 & A209 \\
\hline Chan L & $\mathrm{S} 22: 23 \mathrm{am} 12: \mathrm{A} / \mathrm{Co}$ & 74 & A282 & Cioni R & $\mathrm{S} 38: 22 \mathrm{pm} 29: \mathrm{B} / \mathrm{Ja}$ & 56 & A589 & Creaser RA & S45:18am10:A/Co & 6 & A156 \\
\hline Chan L & $\mathrm{S} 22: 23 \mathrm{am} 13: \mathrm{A} / \mathrm{Co}$ & 74 & A346 & Cirrincione $\mathrm{R}$ & G01:19pmPO:P288 & 23 & A786 & Creaser RA & S45:18am11:A/Co & 6 & A696 \\
\hline Chang $\mathrm{H}$ & G01:19pmPO:P270 & 23 & A398 & Citeau L & S37:21am05:B/Ja & 39 & A142 & Crich D & $\mathrm{S} 35: 21 \mathrm{am} 12: \mathrm{B} / \mathrm{Pi}$ & 39 & A718 \\
\hline Chang $\mathrm{H}$ & S22:22amPO:P299 & 65 & A442 & Ciuffi $S$ & S11:18pm29:C/A1 & 8 & A143 & Crich D & $\mathrm{S} 34: 22 \mathrm{am} 13: \mathrm{B} / \mathrm{Ja}$ & 49 & A393 \\
\hline Chang Q & S27:23amPO:P229 & 67 & A855 & Civetta L & $\mathrm{S} 14: 19 \mathrm{pm} 28: \mathrm{C} / \mathrm{A} 2$ & 20 & A780 & Croal L & $\mathrm{S} 41: 23 \mathrm{pm} 24: \mathrm{A} / \mathrm{Fm}$ & 81 & A371 \\
\hline Chang VT & $\mathrm{S} 41: 22 \mathrm{pm} 24: \mathrm{A} / \mathrm{Fm}$ & 56 & A129 & Claessens J & S48:19pmPO:P352 & 34 & A143 & Croal LR & S35:19amPO:P244 & 32 & A157 \\
\hline Chang Z & $\mathrm{S} 41: 23 \mathrm{am} 06: \mathrm{A} / \mathrm{Fm}$ & 76 & A432 & Claire C & G07:18pmPO:P348 & 25 & A838 & Cronin TM & $\mathrm{S} 24: 19 \mathrm{pm} 25: \mathrm{B} / \mathrm{Fo}$ & 21 & A203 \\
\hline Chapman $\mathrm{H}$ & S07:19pmPO:P166 & 27 & A129 & Clapp E & S21:21am11:A/Co & 38 & A77 & Cross M & $\mathrm{S} 34: 22 \mathrm{am} 10: \mathrm{B} / \mathrm{Ja}$ & 49 & A481 \\
\hline Chapman H & S22:23am03:A/Co & 74 & A77 & Clark E & $\mathrm{S} 28: 22 \mathrm{pm} 27: \mathrm{B} / \mathrm{Fo}$ & 55 & A105 & Croudace I & $\mathrm{S} 44: 18 \mathrm{pm} 25: \mathrm{A} / \mathrm{St}$ & 10 & A766 \\
\hline Chapon V & $\mathrm{S} 35: 21 \mathrm{am} 10: \mathrm{B} / \mathrm{Pi}$ & 39 & A69 & Clark E & S28:22amPO:P216 & 67 & A104 & Croudace IW & G07:18pmPO:P326 & 24 & A160 \\
\hline Chappell J & $\mathrm{S} 28: 23 \mathrm{am} 12: \mathrm{B} / \mathrm{Fo}$ & 75 & A501 & Clark P & S28:22amPO:P219 & 67 & A640 & Croudace IW & G07:18pmPO:P347 & 25 & A823 \\
\hline Chappellaz J & S39:22pmPO:P348 & 70 & A274 & Clauer N & S21:22pmPO:P285 & 65 & A177 & Crovisier JL & S39:23am03:B/Ja & 75 & A157 \\
\hline Charlet L & G07:19am14:B/Ja & 12 & A783 & Clauer N & S22:22amPO:P306 & 65 & A602 & Crowhurst PV & G01:22am05:A/St & 46 & A158 \\
\hline Charlet L & $\mathrm{S} 48: 19 \mathrm{am} 06: \mathrm{B} / \mathrm{Ja}$ & 17 & A843 & Clauer N & $\mathrm{S} 39: 22 \mathrm{pmPO}: \mathrm{P} 355$ & 70 & A651 & Crowley O & G07:18pmPO:P348 & 25 & A838 \\
\hline Charlet L & G07:18pmPO:P325 & 24 & A130 & Clayton R & S01:18am06:C/S1 & 2 & A171 & Crozaz G & G08:21am08:C/S1 & 36 & A158 \\
\hline Charlet L & G07:18pmPO:P343 & 25 & A646 & Clechenko C & G01:22am12:A/St & 46 & A144 & Cubillas P & $\mathrm{S} 48: 18 \mathrm{am} 08: \mathrm{B} / \mathrm{Ja}$ & 6 & A614 \\
\hline Charlier B & $\mathrm{S} 16: 23 \mathrm{pm} 30: \mathrm{C} / \mathrm{A} 2$ & 79 & A81 & Cleveringa $\mathrm{P}$ & S28:22amPO:P215 & 67 & A62 & Cuello G & G07:18pmPO:P343 & 25 & A646 \\
\hline Charlier BLA & S16:22pmPO:P035 & 63 & A839 & Cline $\mathrm{J}$ & G01:22am04:A/St & 46 & A219 & Cui X & G06:23am08:C/S2 & 72 & A159 \\
\hline Charlier BLA & S16:23pm29:C/A2 & 79 & A130 & Cloquet $\mathrm{C}$ & S41:22amPO:P101 & 71 & A144 & Cuif JP & S49:19am09:A/Fm & 17 & A159 \\
\hline Charnley S & S01:18am11:C/S1 & 2 & A131 & Coates J & S35:21am16:B/Pi & 39 & A145 & Cukrov N & G03:19pmPO:P231 & 24 & A460 \\
\hline Charnock JM & S18:22pmPO:P153 & 64 & A699 & Coath C & S07:18pm25:C/S2 & 8 & A655 & Cummings $\mathbf{P}$ & S37:21pm21:B/Ja & 45 & A160 \\
\hline Chaussidon M & S02:19am02:C/S1 & 12 & A131 & Coburn PM & G08:21am14:C/S1 & 36 & A145 & Cundy AB & G07:18pmPO:P326 & 24 & A 160 \\
\hline Chaussidon M & $\mathrm{S} 11: 19 \mathrm{pm} 27: \mathrm{C} / \mathrm{A} 1$ & 19 & A464 & Cocherie A & S45:18pm29:A/Co & 11 & A146 & Cundy AB & G07:18pmPO:P347 & 25 & A 823 \\
\hline Chaussidon M & $\mathrm{S} 27: 22 \mathrm{am} 07: \mathrm{B} / \mathrm{Fo}$ & 48 & A12 & Cockburn $\mathrm{H}$ & $\mathrm{S} 21: 21 \mathrm{pm} 22: \mathrm{A} / \mathrm{Co}$ & 44 & A106 & Curti E & S39:22pmPO:P345 & 70 & A161 \\
\hline Chaussidon M & $\mathrm{S} 10: 23 \mathrm{pm} 23: \mathrm{C} / \mathrm{A} 1$ & 78 & A725 & Cody G & S01:18am15:C/S1 & 2 & A146 & Curti E & S39:22pmPO:P359 & 70 & A771 \\
\hline Chauvel C & S27:22am06:B/Fo & 48 & A132 & Cody G & S34:23amPO:P314 & 68 & A147 & Curtice J & $\mathrm{S} 40: 22 \mathrm{am} 02: \mathrm{A} / \mathrm{Fm}$ & 50 & $\mathrm{~A} 425$ \\
\hline Chavagnac V & S42:18am09:B/Fo & 5 & A132 & Coe A & $\mathrm{S} 22: 23 \mathrm{pm} 31: \mathrm{A} / \mathrm{Co}$ & 79 & A147 & Curtis G & S19:22am06:C/S2 & 48 & A394 \\
\hline Chazot G & $\mathrm{S} 11: 19 \mathrm{pm} 31: \mathrm{C} / \mathrm{A} 1$ & 19 & A621 & Coetzee LL & S07:18pm24:C/S2 & 8 & A64 & Cushing M & S46:22pmPO:P271 & 71 & A714 \\
\hline Chazot G & G05:21pm26:C/A1 & 41 & $\mathbf{A 1 3 3}$ & Cohen A & $\mathrm{S} 47: 19 \mathrm{am} 13: \mathrm{A} / \mathrm{St}$ & 16 & A436 & Cypionka H & S33:18am07:B/Pi & 4 & A161 \\
\hline Chazot G & G05:22pmPO:P038 & 58 & A29 & Cohen A & S22:23pm31:A/Co & 79 & A147 & & & & \\
\hline Chazot G & S40:22pmPO:P111 & 71 & A864 & Cohen AL & S49:19pm22:A/Fm & 22 & A148 & & & & \\
\hline Cheadle M & S08:21pm21:C/A2 & 43 & A133 & Cohn C & S06:19am14:C/S2 & 13 & A310 & & & & \\
\hline Cheadle MJ & S08:21am09:C/A2 & 37 & A168 & Cole D & S18:21am14:C/S2 & 37 & A427 & & & & \\
\hline Cheminée J & $\mathrm{S} 12: 18 \mathrm{pm} 28: \mathrm{C} / \mathrm{A} 2$ & 9 & A36 & Coleman RG & S09:22am07:C/A1 & 47 & A504 & & & & \\
\hline Chen F & G05:21am13:C/A1 & 36 & A700 & Coles B & G08:21am15:C/S1 & 36 & A533 & & & & \\
\hline Chen F & $\mathrm{G} 01 \cdot 22 \mathrm{am} 07 \cdot \mathrm{A} / \mathrm{St}$ & 46 & A134 & Colin $\mathrm{F}$ & $\mathrm{S} 46 \cdot 23 \mathrm{~nm} 24 \cdot \mathrm{A} / \mathrm{St}$ & 81 & & & & & \\
\hline
\end{tabular}


Goldschmidt 2002 Index

D

S14:19pm28:C/A2

S13:19amPO:P019

S14:18pmPO:P004

S25:21am06:B/Fo

S33:18am01:B/Pi

D'Argenio B

D'Hondt S

D'Orazio M

d'Ozouville N

Dacheng J

Dachs J

Daehn R

Dahl A

Dählmann A

Dahlqvist R

Dakhel N

Dale J

Dallai L

Dallai L

Dalpe C

Dalpe C

Daly JS

Dangic A

Dangic A

Dangic J

Daniel I

Danielson L

Dann J

Dann J

Dann J

S14:19pm28:C/A2

S38:23amPO:P334

G05:22pmPO:P040

$\mathrm{S} 30: 19 \mathrm{am} 01: \mathrm{B} / \mathrm{P}$

S37:21pm28:B/Ja

S36:23amPO:P261

S13:18am03:C/A2

S37:23amPO:P327

$\mathrm{S} 38: 22 \mathrm{pm} 24: \mathrm{B} / \mathrm{J}$

$\mathrm{S} 34: 22 \mathrm{am} 05: \mathrm{B} / \mathrm{Ja}$

G01:19pmPO:P260

G03:19pmPO:P227

S13:18am08:C/A2

S15:18am04:C/A1

S16:22pmPO:P024

G07:19pm30:B/Ja

G08:21pm27:C/S1

G07:19pm30:B/Ja

$\mathrm{S} 18: 21 \mathrm{am} 09 \cdot \mathrm{C} / \mathrm{S} 2$

S03:22pm25:C/S1

S08:21am04:C/A2

S08:21 am05:C/A2

S08:21pm23:C/A2

Danyushevsky LV S08:21am09:C/A2

Darling K

$\mathrm{S} 24 \cdot 19 \mathrm{am} 10 \cdot \mathrm{B} / \mathrm{Fo}$

S07:18pm29:C/S2

S07:18pm31:C/S2

S02:18pm29:C/S1

S49:19am09:A/Fm

G07:18pmPO:P348

S14:19pm27:C/A2

S16:22pmPO:P027

S16:23am12:C/A2

S16:23pm29:C/A2

S17:23amPO:P002

S16:22pmPO:P026

$\mathrm{S} 28: 23 \mathrm{am} 13: \mathrm{B} / \mathrm{Fo}$

S22:23pm27:A/Co

S11:19pm29:C/A1

S14:18pmPO:P012

S10:22amPO:P136

S40:22pmPO:P106

S01:18am06:C/S1

$\mathrm{S} 47: 19 \mathrm{am} 11: \mathrm{A} / \mathrm{St}$

S08:22pmPO:P020

$\mathrm{G} 01: 22 \mathrm{pm} 27: \mathrm{A} / \mathrm{St}$

S19:22am07:C/S2

S19:22am06:C/S2

PLENARY:20am

S25:22amPO:P211

S47:19pmPO:P318

S30:19pm21:B/Pi

G05:22pmPO:P041

S30:19pm30:B/Pi

S48:19pmPO:P357

S13:18am03:C/A2

$\mathrm{S} 23: 18 \mathrm{pm} 24: \mathrm{B} / \mathrm{Fo}$

G04:23pm23:B/Pi

S49:19pm21:A/Fm

$\mathrm{S} 49: 19 \mathrm{pm} 29: \mathrm{A} / \mathrm{Fm}$

$\mathrm{S} 47: 19 \mathrm{am} 14: \mathrm{A} / \mathrm{St}$

S08:21am05:C/A2

S08:21pm23:C/A2

G01:19pmPO:P279

S26:23amPO:P203

$\mathrm{S} 24: 19 \mathrm{pm} 23: \mathrm{B} / \mathrm{Fo}$

G05:21pm22:C/A1

$\mathrm{S} 24: 19 \mathrm{pm} 21 \cdot \mathrm{B} / \mathrm{Fo}$

G05:21pm28:C/A1

S14:18pmPO:P002
Del Nero M

Delaloye M

Delay M

Delaygue G

Dellwig O

Delmonte B

DeLong E

$41 \quad$ A65

Delong EF

Deloule E

Deloule E

A670

29 A242

38 A107

A163

20 A780

69 A265

8 A368

16 A212

A163

68 A164

$\begin{array}{ll}3 & \mathbf{A 1 6 4}\end{array}$

69 A165

$\begin{array}{ll}56 & \text { A337 }\end{array}$

49 A25

23 A89

24 A165

3 A867

$\mathrm{A} 103$

63 A256

18 A166

$42 \mathbf{A 1 6 6}$

18 A166

A489

$\begin{array}{ll}52 & \mathbf{A 1 6 7}\end{array}$

$\begin{array}{ll}37 & \mathbf{A 1 6 7}\end{array}$

37 A294

43 A580

$\begin{array}{ll}37 & \mathbf{A 1 6 8}\end{array}$

15 A33

8 \begin{tabular}{ll}
$\mathbf{A 1 6 8}$ \\
\hline
\end{tabular}

8 A733

$7 \quad$ A169

$17 \quad$ A159

$25 \quad$ A838

20 A535

63 A340

44 A170

79 A130

63 A169

$63 \quad$ A327

75 A375

79 A170

$19 \quad$ A54

29 A796

62 A717

71 A310

2 A171

$16 \quad$ A588

61 A785

51 A640

48 A356

$48 \quad$ A394

35 A2

66 A171

$33 \quad$ A741

$22 \quad \mathbf{1 7 2}$

58 A172

22 A18

34 A262

$3 \quad$ A164

9 A634

$77 \quad$ A313

22 A173

22 A236

16 A596

$37 \quad$ A294

43 A580

23 A651

66 A173

$21 \quad$ A207

$41 \quad \mathbf{A 1 7 4}$

21 A437

$41 \quad$ A65

Deloule $\mathbf{E}$

Deloule E

Deloule E

Delpech G

Delpech G

Delpech G

Delpech G

Demaiffe D

deMenocal $\mathrm{P}$

Demény A

Deng B

Deng $\mathrm{H}$

Deng J

Denton GH

DePaolo D

DePaolo D

DePaolo DJ

Dequincey O

Derry LA

Des Marais D

Deschamps $\mathrm{P}$

Descostes M

Desmurs L

Dessert C

Dessert C

Deutsch A

Devivier K

Devol-Brown I

Devreux F

Deyhle A

Deyhle A

DeYoro JJ

Di Primio R

Di Vincenzo G

Di Vincenzo G

Dia A

Dia A

Diamond LW

Diamond LW

DiChristina T

Dick H

Dick HJ

Dick HJB

Dickens G

Dickens G

Dickens G

Dideriksen K

Dieckmann V

Dietrich VJ

Dietzel M

Dietzel M

Dietzel M

Dikov YP

Dikov YP

Dillon $\mathrm{P}$

Dinelli E

Ding $T$

Dingwell D

Dini A

Dinkel C

Dittrich M

Dittrich M

Dittrich M

Dixon ET

Dmitriev V

S19:22am03:C/S2

S39:22pmPO:P360

G05.22pmPO:P042

G05:22pmPO:P043

G04:22amPO:P245

75

23 A125 Dohmen

50 A247 Dohnalkova A

80 A174 Dold B

51 A107 Dolejs D

48 A175 Dolejs D

39 A571

39 A585

11 A146

$27 \quad$ A96

$37 \quad$ A745

$\begin{array}{ll}40 & \mathbf{A 1 7 5}\end{array}$

A642

63 A816

$4 \quad$ A518

$29 \quad \mathrm{~A} 155$

$36 \mathbf{A 1 7 6}$

62 A584

62 A155

5 A483

$28 \quad$ A176

28 A868

$65 \quad \mathrm{~A} 453$ 


\section{Goldschmidt 2002 Index}

12:19pmPO:P041 S14:18pmPO:P010 $\mathrm{S} 44: 18 \mathrm{pm} 26: \mathrm{A} / \mathrm{St}$ S44:19amPO:P299 S44:19amPO:P301 S28:23pm25:B/Fo S18:22pmPO:P150

Ebel DS

Ebihara M

Ebisawa $\mathbf{N}$

Eckert C

Edwards D

Edwards L

Eggenberger U

Eggins S

Eggins S

Eggins $\mathrm{S}$

Eggleston C

Eggleston C

Ehlers TA

Ehrenfreund P

Ehrlich S

Ehrlich S

Eick MJ

Eighmy T

Eikenberg J

Eiler J

Eiler J

Eiler J

Eilrich B

Einaudi MT

Eirik Jens K

Eiriksdottir ES

Eisele J

Eisenhauer A

Eisenhauer A

Eisenhauer A

Eisenhauer A

Eisenhauer A

Eisenhauer A

Eisenreich $\mathbf{S}$

Ekici T

El Goresy A

El Goresy A

EI Goresy A

Elbaz-Poulichet F

Elbert D

Elburg M

Elburg M

Elderfield $\mathbf{H}$

Elderfield $\mathrm{H}$

Elgood R

Elkins J

Elkins L

Elliott T

Elliott T

Elliott T

Elliott T

Elliott T

Elliott T

Elliott T

Ellis AS

Elsass F

Elsass $\mathrm{P}$

Elsner M

Elvert M

Ely J

Elzinga E

Embaye T

Embey-Isztin A

Embey-Isztin A

Emeis K

Emmanuel S

Emmenegger L

Enel M

Engelen B

Engelstaedter S

Enmar R

Erbs M

Erel Y

Erez J

Erez J

Ernstsen V
S02:19pm25:C/S1

S02:18amPO:P149

S40:21am07:A/Fm

S49:18pmPO:P109

S36:22am12:B/Pi

S16:23am11:C/A2

S39:23pm21:B/Ja

S14:19am06:C/A2

S24:19pm23:B/Fo

S12:19pmPO:P042

S48:18am12:B/Ja

$\mathrm{S} 48: 18 \mathrm{am} 13: \mathrm{B} / \mathrm{Ja}$

S21:21pm25:A/Co

S01:18am12:C/S1

S44:18am06:A/St

S44:19amPO:P296

$\mathrm{S} 48: 18 \mathrm{pm} 32: \mathrm{B} / \mathrm{Ja}$

S39:23pm27:B/Ja

S39:23am06:B/Ja

S43:21am09:A/St

S43:21 am03:A/St

S10:23pm26:C/A1

G04:23pm21:B/Pi

S17:22pm25:C/A2

S45:18am14:A/Co

$\mathrm{S} 22: 22 \mathrm{pm} 25: \mathrm{A} / \mathrm{Co}$

S10:23pm21:C/A1

S24:19am13:B/Fo

S24:19am09:B/Fo

S24:19am10:B/Fo

S15:19amPO:P060

S24:18pmPO:P211

S22:22amPO:P301

S30:19am01:B/Pi

G05:22pmPO:P037

S02:19pm28:C/S1

G08:19pmPO:P155

G08:21am09:C/S1

$\mathrm{S} 48: 18 \mathrm{pm} 25: \mathrm{B} / \mathrm{Ja}$

G09:18pm21:A/Fm

S14:19pm29:C/A2

S14:19pm24:C/A2

S24:19am15:B/Fo

$\mathrm{S} 26: 22 \mathrm{pm} 25: \mathrm{B} / \mathrm{Fo}$

$\mathrm{S} 38: 22 \mathrm{pm} 28: \mathrm{B} / \mathrm{Ja}$

$\mathrm{S} 35: 21 \mathrm{pm} 21: \mathrm{B} / \mathrm{Pi}$

S08:21pm28:C/A2

S44:18am11:A/St

S11:18pm25:C/A1

S11:19am01:C/A1

S10:22amPO:P126

S16:22pmPO:P026

S03:23am11:C/S1

S10:23pm28:C/A1

$\mathrm{S} 41: 23 \mathrm{pm} 27: \mathrm{A} / \mathrm{Fm}$

S37:21 am05:B/Ja

S22:23am09:A/Co

S32:18pm31:B/Pi

S35:21am04:B/P

S03:22am01:C/S

$\mathrm{S} 48: 18 \mathrm{am} 09: \mathrm{B} / \mathrm{Ja}$

$\mathrm{S} 35: 21 \mathrm{am} 09: \mathrm{B} / \mathrm{Pi}$

S12:19pmPO:P034

G05:22pmPO:P043

S26:22pm21:B/Fo

S41:23am12:A/Fm

$\mathrm{S} 36: 21 \mathrm{pm} 29: \mathrm{B} / \mathrm{Pi}$

G04:22amPO:P236

S33:18am07:B/Pi

S27:22am04:B/Fo

S49:19pm30:A/Fm

$\mathrm{S} 32: 18 \mathrm{pm} 31: \mathrm{B} / \mathrm{Pi}$

S30:19pm 24:B/Pi

S49:19am07:A/Fm

G04:22amPO:P238

$\mathrm{S} 48: 18 \mathrm{pm} 31: \mathrm{B} / \mathrm{Ja}$
$18 \quad \mathbf{A 2 0 5}$

26 A205

40 A206

34 A804

50 A541

74 A35

80 A206

$14 \quad$ A754

$21 \quad \mathbf{2 0 7}$

28 A848

$\begin{array}{ll}6 & \mathrm{A207}\end{array}$

$\begin{array}{ll}6 & \text { A734 }\end{array}$

44 A208

$\begin{array}{ll}2 & \mathbf{A 2 0 8}\end{array}$

5 A303

33 A209

1 A759

A209
A20

75 A210

40 A210

$40 \quad$ A622

78 A151

7 A211

53 A430

6 A51

54 A275

78 A336

5 A87

15 A211

5 A331

29 A184

$31 \quad$ A299

65 A456

16 A212

58 A15

$18 \quad$ A212

$25 \quad$ A59

36 A702

11 A526

$7 \quad$ A689

$2 \quad \mathbf{2 1 3}$

$\begin{array}{ll}20 & \mathrm{~A} 238\end{array}$

$15 \quad$ A213

54 A115

56 A25

44 A390

43 A365

5 A97

8 A555

$14 \quad$ A719

62 A364

63 A327

73 A417

$\begin{array}{ll}78 & \text { A214 }\end{array}$

A 370

39 A142

$74 \quad \mathrm{~A} 127$

$10 \quad \mathrm{~A} 301$

$39 \quad \mathbf{A 2 1 4}$

$46 \quad$ A372

$6 \quad$ A628

$39 \quad$ A752

28 A176

$58 \quad$ A188

54 A215

76 A494

44 A378

$57 \quad$ A215

4 A161

$48 \quad$ A766

$22 \quad \mathrm{~A} 436$

10 A301

22 A700

$17 \quad \mathbf{2 1 6}$

57 A267

11 A226

$\begin{array}{ll}\text { Erzinger J } & \text { S14:18pmPO:P010 } \\ \text { Esat T } & \text { S44:18pm26:A/St } \\ \text { Esat T } & \text { S44:19amPO:P299 } \\ \text { Esat T } & \text { S44:19amPO:P301 } \\ \text { Esat T } & \text { S28:23pm25:B/Fo } \\ \text { Escalier J } & \text { S18:22pmPO:P150 } \\ \text { Escrig S } & \text { S10:22amPO:P121 } \\ \text { Eusden D } & \text { S39:23pm27:B/Ja } \\ \text { Evans D } & \text { S44:19amPO:P297 } \\ \text { Evans J } & \text { S45:18pm24:A/Co } \\ \text { Evans J } & \text { S29:19pm21:A/St } \\ \text { Evans J } & \text { S46:23am06:A/St } \\ \text { Evans JA } & \text { S45:18pm24:A/Co } \\ \text { Evans M } & \text { S22:23am04:A/Co } \\ \text { Evans N } & \text { G01:22am04:A/St } \\ \text { Evans P } & \text { S16:23am08:C/A2 } \\ \text { Evstigneeva TL } & \text { G09:18am07:A/Fm } \\ \text { Ewing R } & \text { S39:22pmPO:P358 } \\ \text { Ewing R } & \text { S39:22pmPO:P363 } \\ \text { Ewing R } & \text { S39:23am01:B/Ja } \\ \text { Exley C } & \text { G04:22amPO:P248 } \\ & \\ & \\ & \\ & \\ & \end{array}$

Fabel D

Fabian D

Faccini B

Faganeli J

Faganeli J

Fairchild I

Fairchild I

Fairchild I

Fairchild IJ

Faivre D

Fallick A

Fallick AE

Fallon S

Falloon T

Famin V

Fang J

Fanning CM

Farges $\mathbf{F}$

Farges $F$

Farley K

Farley K

Farley K

Farley K

Farley K

Farley KA

Farley KA

Farley KA

Farley KA

Farquhar J

Farquhar J

Faul U

Faure $\mathbf{F}$

Favre F

Fayek M

Fayek M

Fazlulin S

Fedkin $\mathrm{M}$

Fedo CM

Fedorova

Fehr M

Fein JB

Fein JB

Fein JB

Feineman MD 
Goldschmidt 2002 Index

Author

Code

S07:18am04:C/S2

S14:18pmPO:P009

Fournelle J

S07:18am 14:C/S2

Fowler M

Fowler M

France-Lanord C

S07:19pmPO:P166

$\mathrm{S} 21: 21 \mathrm{pm} 21: \mathrm{A} / \mathrm{Co}$

S22:23am04:A/Co

S22:23am02:A/Co

France-Lanord C

$\mathrm{S} 46: 23 \mathrm{am} 08: \mathrm{A} / \mathrm{St}$

G08:21am03:C/S1

S02:18pm 25:C/S 1

Franchi

Franchi IA

Franciosi L

Francis D

Francis D

Franck P

Francois L

Francois L

François L

François LM

Francois R

Francois R

Frank M

Frank M

Frank M

Frank M

Frank M

Frank M

Frank TD

Frape $S$

Fraser D

Fraser DG

Frazier $\mathrm{S}$

Frederick F

Fredrickson JK

Freedman $\mathrm{P}$

Freedman PA

Freeman K

Freeman $\mathrm{KH}$

Frei R

Frei R

Frei R

Frei R

Freiberger R

Fretzdorff S

Fricke $\mathrm{H}$

Friend $\mathrm{C}$

Frikken $\mathrm{P}$

Frimmel FH

Frisia $S$

Frost DJ

Frueh-Green GL

Fryer $\mathrm{P}$

Fryer $\mathrm{P}$

$\mathrm{Fu} F$

$\mathrm{Fu} S$

Fujii T

Fukugawa $\mathrm{K}$

Fukushi K

Fukuyama M

Furrer G

Furrer G

Furrer $\mathrm{G}$

Furrer $\mathrm{G}$

Furukawa Y

S19:22pm27:C/S2

Prog. Abs. Author

3 A125

29 A611

3 A289

$27 \quad$ A129

44 A720

74 A178

$\begin{array}{ll}\mathbf{7 4} & \mathbf{A 2 4 2}\end{array}$

$76 \quad$ A267

36 A45

$7 \quad$ A512

$29 \quad \mathrm{~A} 242$

8 A860

14 A594

$76 \quad$ A838

13 A281

65 A615

54 A202

38 A243

$9 \mathbf{A 2 4 3}$

$75 \quad \mathrm{~A} 503$

5 A33

5 A142

5 A244

5 A795

52 A673

$56 \quad$ A629

8 A468

$55 \quad$ A445

2 A853

$12 \quad \mathbf{A 4 5 5}$

68 A244

$20 \quad$ A200

11 A502

5 A303

5 A245

38 A578

$38 \quad \mathrm{~A} 423$

3 A649

$43 \quad$ A245

$47 \quad$ A504

$65 \quad$ A456

$63 \quad$ A246

33 A246

21 A531

73 A68

$63 \quad$ A169

$\begin{array}{ll}50 & \mathbf{A 2 4 7}\end{array}$

25 A247

$\begin{array}{ll}73 & \text { A248 }\end{array}$

59 A94

3 A528

28 A670

34 A248

29 A249

71 A310

32 A16

69 A249

59 A250

11 A48

11 A250

25 A841

$57 \quad$ A829

53 A251
Gaab AS S44:19amPO:P306

S30:19am07:B/Pi

S30:18amPO:P254

S36:22am02:B/Pi

S19:22am14:C/S2

S11:18pm26:C/A1

G05:21am05:C/A1

S24:19pm26:B/Fo

G03:19pmPO:P228

S24:18pmPO:P214

$\mathrm{S} 28: 23 \mathrm{am} 12: \mathrm{B} / \mathrm{Fo}$

S16:22pmPO:P024

S48:19pmPO:P355

S48:19pmPO:P357

G10:22pmPO:P280

S30:19pm29:B/Pi

$\mathrm{S} 19: 22 \mathrm{pm} 25: \mathrm{C} / \mathrm{S} 2$

S36:23amPO:P261

$\mathrm{S} 25: 21 \mathrm{am} 10: \mathrm{B} / \mathrm{Fo}$

S21:21am04:A/C

$\mathrm{S} 22: 22 \mathrm{pm} 29: \mathrm{A} / \mathrm{Co}$

$\mathrm{S} 22: 23 \mathrm{pm} 23: \mathrm{A} / \mathrm{Co}$

G08:21am10:C/S1

S10:23pm21:C/A1

S10:22amPO:P123

S06:19am15:C/S2

S49:18pmPO:P103

$\mathrm{S} 21: 21 \mathrm{pm} 26: \mathrm{A} / \mathrm{Co}$

S02:18amPO:P150

$\mathrm{S} 17: 22 \mathrm{am} 11: \mathrm{C} / \mathrm{A} 2$

$\mathrm{S} 22: 23 \mathrm{am} 02: \mathrm{A} / \mathrm{C}$

S22:23pm22:A/Co

S41:23pm29:A/Fm

S12:19pmPO:P042

S11:19am11:C/A1

S20:19pm21:A/Co

$\mathrm{S} 31: 22 \mathrm{pm} 24: \mathrm{A} / \mathrm{Co}$

S10:23pm27:C/A1

S22:23pm29:A/Co

S39:22pmPO:P342

S39:22pmPO:P347

S39:22pmPO:P352

$\mathrm{S} 39: 23 \mathrm{am} 13: \mathrm{B} / \mathrm{Ja}$

$\mathrm{S} 28: 23 \mathrm{am} 13: \mathrm{B} / \mathrm{Fo}$

$\mathrm{S} 22: 23 \mathrm{pm} 27: \mathrm{A} / \mathrm{Co}$

S46:23am12:A/St

S13:18am04:C/A2

G08:21pm28:C/S1

G08:21pm23:C/S1

Garbe-Schoenberg D S44:19amPO:P298

Garcia M G01:19pmPO:P277

Garcia T S48:19pmPO:P355

Garcia T

García T
Garcia-Gutiarrez M

Gariépy C

Garofalo PS

Gartvich J

Gaskova O

Gaskova 0

Gaspar M

Gasperini D

Gassama N

Gattuso J

Gaucher E

Gautheron CE

Gauthier-Lafaye F

Gauthier-Lafaye F

Gavrieli I

Gavrieli I

Gavrilenko B

Gayer E

Gazit-Yaari N

Ge C

Gebauer D

Gee MAM

Prog. Abs. Author

Code

Prog. Abs.

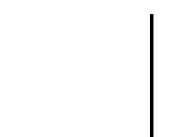

Gehre M

Gehring AU

Geibert W

Geiger S

Geisler T

Geisler T

Geist D

$33 \quad$ A836

Gelabert A

Gellatly AM

Genda H

A632

$50 \quad \mathbf{A 2 5 3}$

$\begin{array}{ll}48 & \mathbf{A 2 5 4}\end{array}$

8 A254

$\begin{array}{ll}36 & \mathbf{A 2 5 5}\end{array}$

21 A255

24 A352

31 A530

75 A501

63 A256

34 A230

34 A262

$60 \quad$ A803

$22 \mathbf{A 2 5 6}$

53 A761

68 A164

38 A243

$\begin{array}{ll}38 & \mathbf{A} 257\end{array}$

54 A202

79 A446

$36 \quad$ A547

78 A336

62 A257

$13 \quad \mathbf{A 2 5 8}$

34 A409

44 A621

26 A258

$47 \quad$ A508

$74 \quad$ A242

79
A259

81 A259

28 A848

14 A776

20 A260

55 A779

78 A260

79 A111

$70 \quad$ A17

$70 \quad$ A261

70 A509

$75 \quad$ A116

75 A375

79 A170

76 A326

3 A262

42 A261

42 A859

$33 \quad$ A246

$23 \quad$ A574

34 A230

$60 \quad \mathrm{~A} 803$

34 A262

69 A515

37 A741

$\begin{array}{ll}77 & \mathbf{A 2 6 3}\end{array}$

$2 \quad \mathbf{A 2 6 3}$ 


\section{Goldschmidt 2002 Index}

Author

Goldstein S

Goldstein S

Goldstein S

Goldstein SL

Goldstein SL

Goldstein SL

Goldstein SL

Golla-Schindler U

Golubev S

Gómez P

Goncalves M

Gonfiantini R

Gong B

Gong B

Gong B

Gopalan K

Gopalan K

Gorby Y

Gosse J

Gosse J

Gounelle M

Gounelle M

Gounelle M

Gounelle M

Gout R

Goutx M

Goyne K

Graeser S

Grafton B

Graham C

Graham EY

Graham M

Graham S

Graham S

Granger D

Granina L

Grantham MC

Granwehr J

Grard A

Grassineau N

Greathouse J

Green O

Gregoire M

Gregoire M

Gregoire M

Grégoire $\mathrm{M}$

Gresch M

Gribble GW

Grice K

Griebler C

Griesshaber E

Griesshaber E

Griffin W

Griffin W

Griffin W

Griffin W

Griffin W

Griffin W

Griffin WL

Griffin WL

Griffin WL

Griffioen J

Grimaldi M

Grimalt J

Grimalt J

Grimalt JO

Grimes S

Griselin M

Groenvold K

Grolimund D

Grolimund D

Grönvold K

Grönvold K

Grosbois C

Gross B

Grossi V

Grotzinger JP

Grousset FE

Grove E

Grove M

Grove T

Grove T

Grove T
Code

S42:18am04:B/Fo

S16:23am10:C/A2

S28:23am05:B/Fo

G03:19pmPO:P233

G03:21pm22:B/Fo

S10:22pm22:C/A1

$\mathrm{S} 28: 23 \mathrm{pm} 30: \mathrm{B} / \mathrm{Fo}$

G09:19amPO:P118

S49:18pmPO:P102

S19:23amPO:P161

G07:18pmPO:P332

S38:22pm29:B/Ja

S07:19am01:C/S2

S20:19am10:A/Co

S13:19amPO:P021

S20:18pmPO:P028

G01:22pm29:A/St

S36:22am11:B/Pi

S21:21am12:A/Co

$\mathrm{S} 46: 23 \mathrm{pm} 26: \mathrm{A} / \mathrm{St}$

S02:19am07:C/S1

S02:19am04:C/S1

S02:19am15:C/S1

G08:21am15:C/S1

$\mathrm{S} 34: 22 \mathrm{am} 16: \mathrm{B} / \mathrm{Ja}$

G04:23am13:B/P

S48:19pmPO:P367

G06:22pmPO:P170

S18:22pmPO:P154

S03:23am07:C/S1

S39:23am 12:B/Ja

S44:19amPO:P299

S47:19am07:A/St

S41:23am07:A/Fm

S21:21am09:A/Co

S30:19pm25:B/P

PLENARY:20am

G09:18pm29:A/Fm

S07:19am03:C/S2

S07:18am14:C/S2

G10:21pm24:A/St

S07:18am11:C/S2

S15:18am07:C/A1

S15:18am08:C/A1

S15:19amPO:P059

G05:21am16:C/A1

G07:18pmPO:P333

S32:18pm21:B/Pi

S34:23amPO:P319

$\mathrm{S} 38: 22 \mathrm{pm} 25: \mathrm{B} / \mathrm{Ja}$

S11:19pm28:C/A1

S11:18amPO:P049

G01:19pmPO:P260

S15:19amPO:P067

G05:21pm30:C/A1

G08:21pm21:C/S1

S10:22amPO:P133

S41:23am07:A/Fm

S47:19am07:A/St

S10:22pm28:C/A1

S10:22amPO:P114

$\mathrm{G} 04: 23 \mathrm{pm} 23: \mathrm{B} / \mathrm{Pi}$

G07:18pmPO:P325

S24:19am07:B/Fo

$\mathrm{S} 26: 22 \mathrm{pm} 25: \mathrm{B} / \mathrm{Fo}$

$\mathrm{S} 27: 22 \mathrm{am} 08: \mathrm{B} / \mathrm{Fo}$

G03:21pm30:B/Fo

S10:23pm24:C/A1

G05:21am10:C/A1

$\mathrm{S} 48: 18 \mathrm{pm} 22: \mathrm{B} / \mathrm{Ja}$

S37:21am06:B/Ja

S12:18pm31:C/A2

S10:22pm28:C/A1

G07:19pm27:B/Ja

S38:22pm23:B/Ja

G04:23am13:B/Pi

S07:19am06:C/S2

$\mathrm{S} 27: 22 \mathrm{am} 12: \mathrm{B} / \mathrm{Fo}$

$\mathrm{S} 22: 23 \mathrm{pm} 25: \mathrm{A} / \mathrm{Co}$

G03:19pmPO:P237

S14:19pm21:C/A2

S08:21am05:C/A2

S08:21pm23:C/A2

Prog. Abs. Author

\section{$5 \quad \mathrm{~A} 658$}

Grove T

A284 Grove T

75 A606 Gruetzner J

4 A476

1 A735

$52 \quad \mathbf{A 2 8 4}$

$80 \quad \mathrm{~A} 773$

5 A384

$34 \quad \mathrm{~A} 285$

64 A483

4 A285

$56 \quad$ A589

3 A874

5 A875

28 A875

$30 \quad$ A793

$51 \mathbf{A 2 8 6}$

$50 \quad$ A286

$\begin{array}{ll}38 & \text { A287 }\end{array}$

81 A403

2 A33

$\begin{array}{ll}2 & \text { A287 }\end{array}$

12 A657

36 A533

49 A567

2 A118

44882

59 A405

64 A845

73 A794

$75 \quad$ A192

A399

$6 \quad$ A292

$\begin{array}{ll}76 & \text { A288 }\end{array}$

$\begin{array}{ll}38 & \mathbf{2 8 8}\end{array}$

$22 \quad$ A289

A2

$7 \quad$ A268

13 A281

$3 \quad \mathbf{A 2 8 9}$

42 A868

3 A101

4 A290

4 A518

29 A155

A 176

24 A290

$\begin{array}{ll}10 & \text { A291 }\end{array}$

68 A823

56 A504

19 A291

27 A561

$23 \quad$ A89

29 A613

41 A20

42 A75

$62 \quad$ A584

76 A288

16 A292

52 A673

$62 \quad$ A38

$7 \quad$ A313

$24 \quad \mathrm{~A} 130$

15 A482

54 A115

48 A524

1 A493

$\begin{array}{ll}78 & \text { A292 }\end{array}$

$36 \quad$ A747

11 A676

$39 \quad \mathbf{A 2 9 3}$

9 A316

52 A673

$18 \quad \mathbf{A 2 9 3}$

56 A632

$72 \quad$ A118

$13 \quad$ A847

48 A92

$79 \quad$ A49

$24 \quad$ A784

$\begin{array}{ll}20 & \text { A294 }\end{array}$

$37 \quad \mathbf{A 2 9 4}$

Gu X

Gueguen C

Guenther D

Guenther D

Guerrot C

Guigue C

Guimera J

Guinness R

Gunnink J

Gunter M

Gunter M

Gunther D

Günther D

Günther D

Günther D

Günther D

inther D

Günther-Leopold I S44:18am07:A/St

Güntner U S24:19am06:B/Fo

Guo J G01:22am07:A/St

Guo L S48:19pmPO:P359

Guo Q G04:22amPO:P239

Guo $Y \quad S 41: 22 \mathrm{pm} 25: \mathrm{A} / \mathrm{Fm}$

Guo Y

Guozhi W

Gur D

Gurenko A

Gurevich V

Guss DM

Gussone N

Gussone N

Gussone N

Gussone N

Gussonne N

Gustafsson Ö

Guyot F

Guyot F

Guyot F

Guyot F 
Goldschmidt 2002 Index

Author

Hattori K

Hattori Y

Hattori Y

Haug G

Hauri E

Hauri E

Hauri E

Hauri E

Hauri E

Hauri EH

Hauri EH

Hauri EH

Hauzenberger C

Hawkesworth C

Hawkesworth C

Hawkesworth C

Hawkesworth CJ

Hayano K

Hayes JM

Hayes JM

Hazen R

Heald SM

Heaney $\mathrm{P}$

Hecht I

Hecht MH

Hedberg M

Hedges L

Hedges R

Hegazy $\mathrm{H}$

Hegner E

Heidelbach F

Heidmann I

Heijlen W

Heimsath AM

Hein J

Hein JR

Heinrich C

Heinrich C

Heinrich C

Heinrich C

Heinrich C

Heinrich CA

Heinrich CA

Heinrich CA

Heinrich CA

Heisinger B

Hékinian R

Helgeson $\mathrm{H}$

Helgeson HC

Helie J

Hellebrand E

Hellebrand E

Hellebrand $\mathrm{E}$

Hellebrand E

Hellevang B

Hellmann R

Helmy $\mathbf{H}$

Hemleben C

Hemley RJ

Hemming NG

Hemming $\mathrm{S}$

Hemming S

Hemming $\mathrm{S}$

Hemming $S$

Hemming SR

Hemond C

Hemond C

Henderson CMB

Henderson $G$

Henderson $G$

Henderson G

Henderson $G$

Henderson G

Henderson $G$

Henderson GM

Henderson GM

Henderson GM

Henderson GM

Henderson GM

Henderson GS

Henning $\mathrm{T}$

Henriksen $\mathrm{K}$

Henry $F$
Code

G05:22pmPO:P056 G05:21 am12:C/A1

S22:22amPO:P297

S24:18pmPO:P211

S12:18pm31:C/A2

S12:19pmPO:P036

S12:19pmPO:P042

S43:21 am07:A/St

S43:21am06:A/St

S11:19am03:C/A1

S10:23am04:C/A1

S10:23am01:C/A1

G06:23am11:C/S2

S26:23amPO:P202

S16:23am09:C/A2

S16:23am13:C/A2

S07:19pmPO:P167

S02:18amPO:P149

PLENARY:20am

S35:21am15:B/Pi

S34:23amPO:P314

S48:18pm26:B/Ja

$\mathrm{S} 37: 21 \mathrm{am} 12: \mathrm{B} / \mathrm{Ja}$

S17:23amPO:P004

G08:21am01:C/S1

$\mathrm{S} 44: 18 \mathrm{pm} 21: \mathrm{A} / \mathrm{St}$

$\mathrm{S} 21: 21 \mathrm{pm} 24: \mathrm{A} / \mathrm{Co}$

S29:19pm29:A/St

G05:22pmPO:P049

S12:19pmPO:P034

S10:23am11:C/A1

S37:21am11:B/Ja

G01:19pmPO:P283

S21:21am13:A/Co

$\mathrm{S} 41: 22 \mathrm{pm} 30: \mathrm{A} / \mathrm{Fm}$

S42:18am03:B/Fo

S47:19am14:A/St

G01:19pmPO:P289

G06:22pmPO:P170

S19:23amPO:P157

G06:23am05:C/S2

S18:21am06:C/S2

S17:22pm22:C/A2

S17:22pm25:C/A2

G06:23pm23:C/S2

$\mathrm{S} 46: 23 \mathrm{pm} 23: \mathrm{A} / \mathrm{St}$

S12:18pm28:C/A2

S34:22am04:B/Ja

S34:22am01:B/Ja

S30:19am04:B/Pi

S11:18pm31:C/A1

S11:19am10:C/A1

S20:19am03:A/Co

S11:18amPO:P052

S16:22pmPO:P025

S48:18am04:B/Ja

G09:18am05:A/Fm

G03:21pm22:B/Fo

G09:18pm24:A/Fm

G03:21pm29:B/Fo

S42:18am04:B/Fo

G03:21pm29:B/Fo

$\mathrm{S} 27: 22 \mathrm{am} 13: \mathrm{B} / \mathrm{Fo}$

$\mathrm{S} 28: 23 \mathrm{am} 05: \mathrm{B} / \mathrm{Fo}$

S27:23amPO:P226

G05:21am02:C/A1

G08:21 am10:C/S1

S18:22pmPO:P153

S24:19am14:B/Fo

G03:19pmPO:P228

S42:19amPO:P220

S22:22amPO:P295

S22:23am10:A/Co

$\mathrm{S} 22: 23 \mathrm{pm} 29: \mathrm{A} / \mathrm{Co}$

$\mathrm{S} 42: 18 \mathrm{am} 12: \mathrm{B} / \mathrm{Fo}$

$\mathrm{S} 42: 18 \mathrm{am} 05: \mathrm{B} / \mathrm{Fo}$

S45:19amPO:P030

S44:19amPO:P294

S22:23am11:A/Co

S36:22am13:B/Pi

S01:19amPO:P147

S49:19am04:A/Fm

S42:19amPO:P222

Prog. Abs. Author

58 A433

36 A755 Heraty L

65 A 315

31 A299 Herbert R

9 A316 Herbert T

28 A437 Hering J

28 A848 Hermann J

40 A85 Hermanns R

$\begin{array}{ll}\text { A315 } & \text { Herrin JS }\end{array}$

gton $R$

\begin{tabular}{ll|l}
73 & A659 & Herrington R \\
Herut B
\end{tabular}

72 A842 Hervig R

66 A49 Hervig R

74 A270 Hespenheide B

74 A316 Hesse M

27 A384 Hesslein R

26 A205 Hetényi M

35 A3 Hetzel R

39 A585 Hetzel R

A147 Heulin T

11 A502 Heumann A

39 A351

A246

36 A413 Heuser A

10 A638 Hewawasam T

44 A235 Hewins RH

21 A604 Hiemstra T

58 A317 Hiemstra T

28 A176 Higgins J

73 A473 Higgins S

$\begin{array}{llll}39 & \text { A317 } & \text { Higgins } \mathrm{S}\end{array}$

23 A683 Hill E

\begin{tabular}{ll|l}
38 & A318 & Hill R
\end{tabular}

56 A629 Hill R

5 A795 Hill R

16 A596 Hill R

23 A811 Hillaire-Marcel C

59 A405

64 A269

$72 \mathrm{~A} 645$

$37 \quad$ A196

53 A 304

53 A430

77 A263

81 A558

9 A36

49 A637

$\begin{array}{ll}49 & \mathbf{A 3 1 8}\end{array}$

$16 \quad \mathbf{A 3 1 9}$

8 A810

14 A319

15 A518

27 A722

63 A320

$\begin{array}{ll}6 & \text { A320 }\end{array}$

$\begin{array}{lll}2 & \mathbf{A 3 2 1}\end{array}$

41 A735

7 A666

41 A881

5 A658

41 A88

$48 \quad$ A877

75 A606

67 A32

$36 \mathbf{A 3 2 2}$

$36 \quad$ A547

64 A699

15 A485

24 A352

32 A67

65 A241

$74 \quad \mathbf{A 3 2 2}$

79 A111

5 A642

5 A736

33 A60

33 A65

74 A606

$50 \quad \mathbf{A 5 9 4}$

$26 \quad$ A540

$17 \mathbf{A 3 2 3}$

32 A364

Code

Prog. Abs.

Author

Code

Prog. Abs.

S20:19am12:A/Co

$\mathrm{S} 32: 18 \mathrm{pm} 29: \mathrm{B} / \mathrm{Pi}$

G07:18pmPO:P331

S38:23amPO:P336

S24:19am05:B/Fo

S30:19pm28:B/Pi

S13:18am13:C/A2

S46:22pmPO:P269

S14:19pm30:C/A2

S40:22am01:A/Fm

G08:21am15:C/S1

S31:22am09:A/Co

$\mathrm{S} 48: 18 \mathrm{am} 04: \mathrm{B} / \mathrm{Ja}$

$\mathrm{S} 03: 22 \mathrm{pm} 25: \mathrm{C} / \mathrm{S} 1$

G04:22amPO:P233

G05:22pmPO:P050

S30:19am03:B/Pi

S30:18amPO:P250

S46:22pmPO:P269

S46:23am12:A/St

$\mathrm{S} 35: 21 \mathrm{am} 10: \mathrm{B} / \mathrm{Pi}$

S16:22pmPO:P026

S24:19am13:B/Fo

S24:19am09:B/Fo

S24:18pmPO:P211

S21:21pm23:A/Co

S02:19am 12:C/S1

$\mathrm{S} 37: 21 \mathrm{pm} 24: \mathrm{B} / \mathrm{Ja}$

$\mathrm{S} 37: 21 \mathrm{pm} 22: \mathrm{B} / \mathrm{Ja}$

S07:19am09:C/S2

$\mathrm{S} 48: 18 \mathrm{am} 12: \mathrm{B} / \mathrm{Ja}$

$\mathrm{S} 48: 18 \mathrm{am} 13: \mathrm{B} / \mathrm{Ja}$

$\mathrm{S} 36: 22 \mathrm{am} 11: \mathrm{B} / \mathrm{Pi}$ 


\section{Goldschmidt 2002 Index}

\begin{tabular}{|c|c|c|c|c|c|c|c|c|c|c|c|}
\hline Author & Code & Prog. & Abs. & Author & Code & Prog. & Abs. & Author & Code & Prog. & Abs. \\
\hline Huang S & G06:22pmPO:P176 & 59 & A648 & Ishizuka O & S14:19am11:C/A2 & 14 & A357 & Jendrzejewski N & $\mathrm{S} 12: 18 \mathrm{pm} 29: \mathrm{C} / \mathrm{A} 2$ & 9 & A121 \\
\hline Huang W & S38:23amPO:P335 & 69 & A345 & Ishizuka O & S44:19amPO:P295 & 33 & A194 & Jendrzejewski N & S12:19pmPO:P039 & 28 & A605 \\
\hline Hubberten HW & S49:18pmPO:P109 & 34 & A804 & Issiki H & S14:18pmPO:P013 & 29 & A858 & Jendrzejewski N & S39:22pmPO:P350 & 70 & A435 \\
\hline Hudson-Edwards KA & G04:23am12:B/Pi & 72 & A514 & Ito $\mathbf{E}$ & S30:19am05:B/Pi & 16 & A357 & Jenkin G & S20:19pm22:A/Co & 20 & A365 \\
\hline Huff T & G06:23am07:C/S2 & 72 & A543 & Ito E & G03:21pm26:B/Fo & 41 & A701 & Jenkyns HC & S41:23am12:A/Fm & 76 & A494 \\
\hline Hug S & S30:19pm27:B/Pi & 22 & A450 & Ittekkot V & S23:19pmPO:P209 & 30 & A685 & Jenner G & S08:21pm28:C/A2 & 43 & A365 \\
\hline Hug SJ & G07:19am13:B/Ja & 12 & A346 & Ivanov Z & G06:23am05:C/S2 & 72 & A645 & Jensen K & S39:22pmPO:P358 & 70 & A742 \\
\hline Huh Y & S22:23am13:A/Co & 74 & A346 & Ivy-Ochs S & $\mathrm{S} 28: 22 \mathrm{pm} 32: \mathrm{B} / \mathrm{Fo}$ & 55 & A565 & Jeong GY & S22:22amPO:P298 & 65 & A366 \\
\hline Huisman DJ & G07:19am11:B/Ja & 12 & A347 & Ivy-Ochs S & $\mathrm{S} 28: 22 \mathrm{pm} 30: \mathrm{B} / \mathrm{Fo}$ & 55 & A672 & Jephcoat A & S07:18am11:C/S2 & 3 & A101 \\
\hline Humayun M & S15:18am12:C/A1 & 4 & A347 & Ivy-Ochs S & S21:22pmPO:P289 & 65 & A408 & Jeppson L & S23:19pmPO:P201 & 30 & A23 \\
\hline Humayun M & S02:19am11:C/S1 & 12 & A117 & Ivy-Ochs S & S46:22pmPO:P268 & 71 & A421 & Jeremiason $\mathrm{J}$ & S30:19am01:B/Pi & 16 & A 212 \\
\hline Humayun M & S02:19am13:C/S1 & 12 & A639 & Ivy-Ochs S & S46:23am12:A/St & 76 & A326 & Jersek M & G09:19amPO:P116 & 25 & A366 \\
\hline Humayun M & S02:19am12:C/S1 & 12 & A869 & Ivy-Ochs S & S46:23pm23:A/St & 81 & A558 & Jersek M & G09:19amPO:P120 & 26 & A514 \\
\hline Humayun M & S08:21pm27:C/A2 & 43 & A616 & Iwata $\mathrm{N}$ & G01:19pmPO:P268 & 23 & A358 & Ji H & G09:19amPO:P117 & 25 & A367 \\
\hline Humayun M & S03:22pm23:C/S1 & 52 & A656 & Izbicki J & S40:22pmPO:P107 & 71 & A424 & Ji H & G09:19amPO:P129 & 26 & A136 \\
\hline Humayun M & S17:23amPO:P003 & 63 & A177 & Izraeli ES & $\mathrm{S} 12: 18 \mathrm{pm} 32: \mathrm{C} / \mathrm{A} 2$ & 9 & A403 & Ji H & G09:19amPO:P131 & 26 & A821 \\
\hline Hummel W & S39:22pmPO:P349 & 70 & A348 & & & & & Ji H & G04:22amPO:P246 & 57 & A572 \\
\hline Hummel W & S39:22pmPO:P349 & 70 & A348 & & & & & Jia Y & S07:18pm28:C/S2 & 8 & A 367 \\
\hline Hummel W & S39:22pmPO:P359 & 70 & A771 & & & & & Joachimski M & S49:19pm28:A/Fm & 22 & A37 \\
\hline Hunkeler D & S32:18pm30:B/Pi & 10 & A348 & & & & & Joachimski M & $\mathrm{S} 25: 21 \mathrm{am} 04: \mathrm{B} / \mathrm{Fo}$ & 38 & A 423 \\
\hline Hunter A & G05:21am03:C/A1 & 36 & A279 & & & & & Job R & S11:18amPO:P049 & 27 & A561 \\
\hline Hunter M & S07:19pmPO:P166 & 27 & A129 & & & & & Jocelyne H & G07:18pmPO:P320 & 24 & A6 \\
\hline Hunziker J & $\mathrm{S} 17: 22 \mathrm{am} 14: \mathrm{C} / \mathrm{A} 2$ & 47 & A233 & & & & & Jochum KP & S47:19pmPO:P319 & 33 & A744 \\
\hline Hunziker J & S34:23amPO:P317 & 68 & A691 & & & & & Jochum KP & S09:22am06:C/A1 & 47 & A368 \\
\hline Huo R & S22:22amPO:P303 & 65 & A471 & & & & & Jochum KP & $\mathrm{S} 10: 23 \mathrm{pm} 21: \mathrm{C} / \mathrm{A} 1$ & 78 & A336 \\
\hline Hurford A & $\mathrm{S} 21: 22 \mathrm{pmPO}: \mathrm{P} 284$ & 65 & A55 & & & & & Joel B & S47:19pmPO:P315 & 33 & A395 \\
\hline Hurford T & $\mathrm{S} 45: 18 \mathrm{pm} 23: \mathrm{A} / \mathrm{Co}$ & 11 & A314 & & & & & Joergensen BB & $\mathrm{S} 33: 18 \mathrm{am} 05: \mathrm{B} / \mathrm{Pi}$ & 4 & A 378 \\
\hline Hutcheon ID & S47:19pmPO:P311 & 33 & A42 & Jackson B & S36:23amPO:P261 & 68 & A164 & Joergensen BB & S33:18am13:B/Pi & 4 & A551 \\
\hline Huth J & $\mathrm{G} 01: 22 \mathrm{pm} 25: \mathrm{A} / \mathrm{St}$ & 51 & A609 & Jackson I & S11:19pm24:C/A1 & 19 & A359 & Joergensen BB & G04:22amPO:P250 & 57 & A689 \\
\hline Huthwelker T & G06:23pm21:C/S2 & 77 & A479 & Jackson S & $\mathrm{S} 41: 23 \mathrm{am} 07: \mathrm{A} / \mathrm{Fm}$ & 76 & A288 & Johnsen S & S28:23am09:B/Fo & 75 & A 832 \\
\hline Hyacinthe C & S48:19pmPO:P360 & 34 & A349 & Jackson SE & S47:19am01:A/St & 16 & A359 & Johnson C & S35:19amPO:P244 & 32 & A157 \\
\hline \multirow[t]{12}{*}{ Hyde D } & S08:21pm28:C/A2 & 43 & A365 & Jackson TL & S02:18pm25:C/S1 & 7 & A512 & Johnson C & $\mathrm{S} 41: 23 \mathrm{am} 09: \mathrm{A} / \mathrm{Fm}$ & 76 & A58 \\
\hline & & & & Jacob D & S12:19pmPO:P035 & 28 & A420 & Johnson C & $\mathrm{S} 39: 23 \mathrm{pm} 24: \mathrm{B} / \mathrm{Ja}$ & 80 & A56 \\
\hline & & & & Jacob D & S03:23pmPO:P141 & 61 & A110 & Johnson C & S39:23pm23:B/Ja & 80 & A369 \\
\hline & & & & Jacob D & G06:23am02:C/S2 & 72 & A680 & Johnson C & S41:23pm24:A/Fm & 81 & A371 \\
\hline & & & & Jacob D & S10:23am12:C/A1 & 73 & $\mathbf{A 3 6 0}$ & Johnson CA & $\mathrm{S} 30: 19 \mathrm{pm} 27: \mathrm{B} / \mathrm{Pi}$ & 22 & A450 \\
\hline & & & & Jacobsen B & S47:19pmPO:P314 & 33 & A360 & Johnson CA & G04:22amPO:P257 & 57 & A 829 \\
\hline & & & & Jacobsen C & S05:19pm25:C/S2 & 19 & A237 & Johnson CM & G01:22am13:A/St & 46 & A431 \\
\hline & & & & Jacobsen S & S03:22pm31:C/S1 & 52 & A361 & Johnson EA & G05:21pm21:C/A1 & 41 & A369 \\
\hline & & & & Jacobsen S & S10:23pm30:C/A1 & 78 & A391 & Johnson K & S36:23amPO:P263 & 68 & A370 \\
\hline & & & & Jacobsen SB & $\mathrm{S} 03: 22 \mathrm{pm} 29: \mathrm{C} / \mathrm{S} 1$ & 52 & A863 & Johnson $\mathrm{T}$ & S27:23amPO:P223 & 67 & A278 \\
\hline & & & & Jaenicke R & S27:22am07:B/Fo & 48 & A12 & Johnson TM & S41:23pm27:A/Fm & 81 & A370 \\
\hline & & & & Jaffe P & S19:22pm24:C/S2 & 53 & A361 & Jon D & S14:19pm23:C/A2 & 20 & A200 \\
\hline Ian $\mathrm{H}$ & G07:18pmPO:P348 & 25 & A838 & Jäger C & S01:19amPO:P147 & 26 & A540 & Jones A & S01:18am03:C/S1 & 2 & A371 \\
\hline Ibrahim K & G05:21am08:C/A1 & 36 & A703 & Jagoutz E & G08:21am05:C/S1 & 36 & $\mathbf{A 3 6 2}$ & Jones J & G08:21am02:C/S1 & 36 & A539 \\
\hline Icenhower J & S39:22pmPO:P361 & 70 & A828 & Jahn B & S20:19am10:A/Co & 15 & A875 & Jones J & S03:22am01:C/S1 & 46 & A372 \\
\hline Icenhower J & S39:23pm28:B/Ja & 80 & A351 & Jahnke L & $\mathrm{S} 35: 21 \mathrm{am} 09: \mathrm{B} / \mathrm{Pi}$ & 39 & A752 & Joos F & $\mathrm{S} 28: 23 \mathrm{pm} 23: \mathrm{B} / \mathrm{Fo}$ & 80 & A174 \\
\hline Icenhower J & $\mathrm{S} 39: 23 \mathrm{pm} 30: \mathrm{B} / \mathrm{Ja}$ & 80 & A602 & Jahren AH & $\mathrm{S} 25: 21 \mathrm{am} 05: \mathrm{B} / \mathrm{Fo}$ & 38 & A27 & Jordan $\mathrm{T}$ & $\mathrm{S} 22: 23 \mathrm{am} 12: \mathrm{A} / \mathrm{Co}$ & 74 & A282 \\
\hline Icopini G & S37:21am12:B/Ja & 39 & A351 & Jakobsen R & S19:22pm23:C/S2 & 53 & A362 & Jordana S & S19:23amPO:P159 & 64 & A 372 \\
\hline Igarashi C & G09:19amPO:P115 & 25 & A352 & Jambon A & G09:18pm24:A/Fm & 7 & A666 & Jørgensen B & $\mathrm{S} 33: 18 \mathrm{am} 01: \mathrm{B} / \mathrm{Pi}$ & 4 & A 163 \\
\hline Ihlenfeld C & G03:19pmPO:P228 & 24 & A352 & Jambon A & G08:19pmPO:P155 & 25 & A59 & Josh H & $\mathrm{S} 24: 19 \mathrm{pm} 21: \mathrm{B} / \mathrm{Fo}$ & 21 & A437 \\
\hline Iida Y & S34:23amPO:P318 & 68 & A750 & Jambor JL & S30:19am13:B/Pi & 16 & A616 & Jotter R & G08:21am05:C/S1 & 36 & A362 \\
\hline Iizuka T & S47:19am05:A/St & 16 & A353 & James N & S07:19am04:C/S2 & 13 & A603 & Jourabchi P & S19:23amPO:P160 & 64 & A373 \\
\hline Ikehara M & $\mathrm{S} 23: 18 \mathrm{pm} 29: \mathrm{B} / \mathrm{Fo}$ & 9 & A387 & James R & $\mathrm{S} 21: 21 \mathrm{am} 06: \mathrm{A} / \mathrm{Co}$ & 38 & A806 & Jourdan F & S15:19amPO:P064 & 29 & A 490 \\
\hline Ilani S & $\mathrm{S} 19: 22 \mathrm{am} 14: \mathrm{C} / \mathrm{S} 2$ & 48 & A254 & Jamieson S & S21:22pmPO:P288 & 65 & A401 & Jouzel J & S43:21am01:A/St & 40 & A373 \\
\hline Ilani S & G01:22pm23:A/St & 51 & A311 & Jamtveit B & S19:22am05:C/S2 & 48 & A363 & Jouzel J & S28:23am11:B/Fo & 75 & A623 \\
\hline Ilbeyli N & G05:22pmPO:P051 & 58 & A353 & Jamtveit B & S10:22pm28:C/A1 & 52 & A673 & Jouzel J & S28:23am09:B/Fo & 75 & A832 \\
\hline Ilmberger J & S30:18amPO:P253 & 31 & A434 & Janák M & G01:19pmPO:P287 & 23 & A777 & Jouzel J & S28:23pm29:B/Fo & 80 & A115 \\
\hline Imboden D & $\mathrm{S} 30: 19 \mathrm{am} 11: \mathrm{B} / \mathrm{Pi}$ & 16 & A104 & Janardhan A & G01:19pmPO:P258 & 23 & A860 & Juillet-Leclerc A & S49:18pmPO:P106 & 34 & A636 \\
\hline Immenhauser A & S24:19am11:B/Fo & 15 & A354 & Janda N & S39:22pmPO:P356 & 70 & A671 & Juillet-Leclerc A & G04:22amPO:P240 & 57 & A374 \\
\hline Improta S & G07:18pmPO:P339 & 25 & A479 & Jane M & S08:22pmPO:P015 & 61 & A70 & Juillot F & $\mathrm{S} 48: 18 \mathrm{pm} 25: \mathrm{B} / \mathrm{Ja}$ & 11 & A526 \\
\hline Inagaki F & S33:18am14:B/Pi & 4 & A354 & Jang Y & S39:22pmPO:P363 & 70 & A866 & Juillot F & G07:19pm23:B/Ja & 18 & A374 \\
\hline Ingeneri $\mathrm{K}$ & $\mathrm{S} 44: 18 \mathrm{pm} 21: \mathrm{A} / \mathrm{St}$ & 10 & A638 & Janice $S$ & G07:18pmPO:P320 & 24 & A6 & Juillot F & G07:18pmPO:P342 & 25 & A612 \\
\hline Ingram BL & S47:19pmPO:P311 & 33 & A42 & Jann S & S19:22am07:C/S2 & 48 & A356 & Julie V & S47:19pmPO:P315 & 33 & A395 \\
\hline Ingri J & S37:21am04:B/Ja & 39 & A355 & Janssen C & S02:18pm26:C/S1 & 7 & A824 & Jull AT & S46:23am04:A/St & 76 & A457 \\
\hline Ingri J & S37:23amPO:P327 & 69 & A165 & Jardine P & S19:22am08:C/S2 & 48 & A300 & Jull M & S11:19am05:C/A1 & 14 & A719 \\
\hline Ingrid U & S47:19pmPO:P315 & 33 & A395 & Jarvis $\mathrm{K}$ & S45:18pm23:A/Co & 11 & A314 & Jull M & S10:23pm22:C/A1 & 78 & A375 \\
\hline Innocenti F & S14:19pm28:C/A2 & 20 & A780 & Jasper T & S24:18pmPO:P212 & 31 & A411 & Jull T & $\mathrm{S} 46: 23 \mathrm{pm} 30: \mathrm{A} / \mathrm{St}$ & 81 & A461 \\
\hline Inoue $\mathrm{T}$ & G09:18am11:A/Fm & 2 & A135 & Javoy M & S13:18am07:C/A2 & 3 & A113 & Jun Y & $\mathrm{S} 36: 21 \mathrm{pm} 27: \mathrm{B} / \mathrm{Pi}$ & 44 & A 488 \\
\hline Introne D & S43:22pmPO:P267 & 71 & A418 & Javoy M & S12:18pm28:C/A2 & 9 & A36 & Jung $S$ & S20:19pm29:A/Co & 20 & A376 \\
\hline Ione $\mathbf{K}$ & S05:19pm28:C/S2 & 19 & A355 & Javoy M & S12:18pm29:C/A2 & 9 & A121 & Jung $S$ & S28:23am13:B/Fo & 75 & A375 \\
\hline Ioniov D & S15:19amPO:P066 & 29 & A516 & Javoy M & S12:19pmPO:P039 & 28 & A605 & Jung S & $\mathrm{S} 22: 23 \mathrm{pm} 27: \mathrm{A} / \mathrm{Co}$ & 79 & A170 \\
\hline Ionov D & S10:22amPO:P125 & 62 & A356 & Javoy M & S03:22am05:C/S1 & 46 & $\mathbf{A 3 6 3}$ & & & & \\
\hline Ionov DA & S10:22amPO:P126 & 62 & A364 & Javoy M & S03:23pmPO:P142 & 61 & A377 & & & & \\
\hline Ireland TR & S06:19am16:C/S2 & 13 & A 312 & Javoy M & S39:22pmPO:P350 & 70 & A435 & & & & \\
\hline Isabelle M & S04:23amPO:P146 & 61 & A9 & Jayanetti S & S18:21am11:C/S2 & 37 & A496 & & & & \\
\hline Isenbeck-Schroeter $\mathrm{M}$ & & & & Jayasuriya K & G09:18pm25:A/Fm & 7 & A73 & & & & \\
\hline & S19:22am07:C/S2 & 48 & A356 & Jeandel C & S42:18am11:B/Fo & $\mathbf{5}$ & A427 & & & & \\
\hline Isenbeck-Schröter M & S30:18amPO:P253 & 31 & A434 & Jeandel C & S42:19amPO:P222 & 32 & A364 & & & & \\
\hline Ishibashi J & G06:22pmPO:P179 & 60 & A726 & Jeanloz R & S10:23am07:C/A1 & 73 & A708 & & & & \\
\hline Ishii $\mathrm{T}$ & S14:18pmPO:P007 & 29 & A556 & Jeffcoate A & S10:23pm28:C/A1 & 78 & A214 & & & & \\
\hline Ishimura $\mathrm{Y}$ & S27:23amPO:P222 & 67 & A223 & Jeffcoate AB & S10:22amPO:P126 & 62 & A364 & & & & \\
\hline & & 26 & & Jeffries $\mathrm{T}$ & & & & & & & \\
\hline
\end{tabular}


$\mathbf{K}$

Kachi T

Kadambi J

Kadik A

Kafri R

Kagan E

Kagi $\mathrm{H}$

Kagi H

Kagi R

Kagi RI

Kah LC

Kaiser E

Kalfoun F

Kallmeyer J

Kallmeyer J

Kalt A

Kalvoda J

Kamber B

Kamber B

Kamber B

Kamber B

Kamber BS

Kamenetsky M

Kamenetsky M

Kamenetsky V

Kamenetsky V

Kamenetsky V

Kamenetsky V

Kamenetsky V

Kamenetsky VS

Kamenov B

Kamensky I

Kaminski E

Kamo S

Kamohara $\mathrm{H}$

Kanayama S

Kanayama S

Kaneda H

Kaneoka I

Kaneoka I

Kaneoka I

Kang S

kani T

Kani T

Kanzaki M

Kanzaki M

Karchevsky P

Kardjilov MI

Karen VD

Karhu J

Karl F

Karlby L

Karnland O

Karstbjerg Jensen B

Kasama T

Kasama T

Kasemann SA

Kashima K

Kashiv Y

Kashiwagi $\mathrm{H}$

Kasian SEM

Kasting J

Kastner M

Kathuria A

Katzir Y

Kaufman A

Kaufman AJ

Kaufman AJ

Kaulina T

Kawabe I

Kawahata $\mathrm{H}$

Kawamura K

Kawamura K

Kawano M

Kaygusuz A

Kaygusuz A

Kearsley A
S14:18pmPO-P011 S48:19pmPO:P366 S03:23pmPO:P142 S06:19am11:C/S2 S45:18pm30:A/Co G09:19amPO:P123 S40:22am12:A/Fm S34:22am07:B/Ja

S34:23amPO:P319 S07:18pm23:C/S2 $\mathrm{S} 36: 21 \mathrm{pm} 29: \mathrm{B} / \mathrm{Pi}$ S09:22am05:C/A1 S33:18am05:B/Pi S23:19pmPO:P208 G06:22pmPO:P180 S46:23pm27:A/St S13:18am11:C/A2 S09:22am09:C/A1 S09:22am10:C/A1

S10:23am13:C/A1 S07:18am03:C/S2 S11:18pm24:C/A1 S10:22amPO:P127 S11:18pm24:C/A1 S14:19am06:C/A2 S17:22am10:C/A2 S17:23amPO:P001 S17:23amPO:P002 S12:19pmPO:P037 G05:22pmPO:P052 $\mathrm{S} 31: 22 \mathrm{pm} 24: \mathrm{A} / \mathrm{Co}$ S40:22am09:A/Fm G01:22pm30:A/St G01:22am01:A/St S27:23amPO:P227 S27:23amPO:P229 S18:22pmPO:P151 S40:22am08:A/Fm $\mathrm{S} 40: 22 \mathrm{am} 12: \mathrm{A} / \mathrm{Fm}$ S40:22pmPO:P106 S43:22pmPO:P267 S14:18pmPO:P008 G05:22pmPO:P053 G09:18am13:A/Fm G05:21pm23:C/A1 S12:19pmPO:P043 S22:22pm25:A/Co S41:23am09:A/Fm S07:18pm30:C/S2 S22:22pm31:A/Co S48:19pmPO:P361 S19:23amPO:P155 S08:21pm29:C/A2 S07:18pm32:C/S2 G09:19amPO:P118 S07:19pmPO:P167 G03:21pm24:B/Fo S01:19amPO:P143 G03:19pmPO:P229 $\mathrm{S} 30: 19 \mathrm{am} 03: \mathrm{B} / \mathrm{Pi}$ S03:23am01:C/S1 S26:22pm24:B/Fo S18:21 am07:C/S2 G06:22pmPO:P169 S28:23pm27:B/Fo S07:18pm26:C/S2 S07:19am05:C/S2 G01:19pmPO:P269 S07:19am02:C/S2 G07:18pmPO:P344 S23:18pm29:B/Fo S27:23amPO:P222 S36:23amPO:P264 G05:22pmPO:P039 G05:22pmPO:P054 S05:18pmPO:P165
Kelemen P

Kelemen P

Kelemen P

Kelemen P

Kelemen P

Kelemen P

Keller L

29 A696

Keller M

34 A871 Kelley DS

61 A377

3 A429

11 A377 Kelley S

26 A570 Kelley S

50 A858 Kelley S

\begin{tabular}{ll|l}
49 & A794 & Kellogg J
\end{tabular}

68 A823 Kellogg L

8 A468 Kellogg LH

4 A 378

$47 \quad$ A85

$30 \quad \mathrm{~A} 555$

60 A740

81 A98

3 A404

$47 \quad$ A148

$\begin{array}{ll}47 & \mathbf{A 3 7 9}\end{array}$

$73 \quad \mathrm{~A} 538$

3 A684

8 A860

62 A380

$8 \quad \mathrm{~A} 860$

14 A754

47 A379

$63 \quad$ A54

63 A169

28 A511

58 A 380

55 A779

$50 \quad$ A522

51 A419

46 A760

67 A381

67 A855

64 A491

50 A381

$50 \quad$ A858

71 A310

$71 \quad$ A418

29 A

$58 \quad$ A382

2 A853

41 A382

28 A868

54 A275

76 A58

8 A383

54 A343

34 A 383

64 A26

43 A245

8 A537

25 A 384

27 A384

41 A815

26 A385

24 A385

16 A325

$\begin{array}{ll}73 & \mathbf{A 3 8 6}\end{array}$

54 A489

37 A467

59 A386

80 A39

8 A 840

13 A335

23 A387

$13 \quad$ A497

$25 \quad$ A787

$\begin{array}{ll}9 & \mathbf{A 3 8 7}\end{array}$

$67 \quad$ A223

68 A388

58 A 35

58 A388

$27 \quad$ A586

S11:19am12:C/A1 S14:19am04:C/A2

S11:19am01:C/A1

S11:19am05:C/A1

S11:19am09:C/A1

S11:19pm27:C/A

S05:19pm 25:C/S2

S35:21pm21:B/Pi

G06:22pmPO:P163

S15:18am02:C/A1

$\mathrm{S} 45: 18 \mathrm{pm} 22: \mathrm{A} / \mathrm{Co}$

S20:19pm25:A/Co

$\mathrm{S} 22: 23 \mathrm{pm} 28: \mathrm{A} / \mathrm{Co}$

S16:23pm28:C/A2

S10:23pm30:C/A1

S10:22pm29:C/A1

S10:22amPO:P122

$\mathrm{S} 22: 23 \mathrm{pm} 24: \mathrm{A} / \mathrm{Co}$

S28:22amPO:P217

S10:22amPO:P115

S14:19am12:C/A2

G05:22pmPO:P043

S08:22pmPO:P019

S10:22amPO:P128

S36:22am07:B/P

$\mathrm{S} 48: 19 \mathrm{am} 07: \mathrm{B} / \mathrm{J}$

$\mathrm{S} 35: 21 \mathrm{am} 12: \mathrm{B} / \mathrm{Pi}$

S34:22am13:B/Ja

S07:19am08:C/S2

S47:19pmPO:P314

S47:19pmPO:P315

S19:22am07:C/S2

S19:22am06:C/S2

S32:18pm27:B/Pi

G10:21pm22:A/S

G04:22pm24:B/Pi

S08:22pmPO:P019

S10:22amPO:P134

S08:22pmPO:P018

S07:18pm28:C/S2

S13:18am01:C/A2

S25:21am12:B/Fo

S08:21pm28:C/A2

S07:19pmPO:P168

G01:19pmPO:P263

G04:22amPO:P234 
Goldschmidt 2002 Index

Author

Code

S48:18pm24:B/Ja $\mathrm{S} 48: 18 \mathrm{pm} 23: \mathrm{B} / \mathrm{Ja}$ G07:19pm24:B/Ja S48:19pmPO:P365 $\mathrm{S} 37: 21 \mathrm{am} 11: \mathrm{B} / \mathrm{Ja}$ $\mathrm{S} 36: 22 \mathrm{am} 06: \mathrm{B} / \mathrm{Pi}$ S36:23amPO:P262 S43:22pmPO:P267 S45:18am01:A/Co S37:23amPO:P329 G09:19amPO:P120 S17:23amPO:P007 G01:22am10:A/St G01:22pm30:A/St S20:19am03:A/Co S12:19pmPO:P035 S22:22amPO:P301 $\mathrm{S} 28: 23 \mathrm{am} 13: \mathrm{B} / \mathrm{Fo}$ S02:19am09:C/S1 S14:18pmPO:P005 S18:21am04:C/S2 G01:19pmPO:P271 S48:19pmPO:P367 $\mathrm{S} 42: 18 \mathrm{am} 06: \mathrm{B} / \mathrm{Fo}$ S21:21am14:A/Co $\mathrm{S} 21: 21 \mathrm{pm} 23: \mathrm{A} / \mathrm{Co}$ S21:22pmPO:P291 S28:22amPO:P217 $\mathrm{S} 42: 18 \mathrm{am} 10: \mathrm{B} / \mathrm{Fo}$ $\mathrm{S} 28: 22 \mathrm{pm} 30: \mathrm{B} / \mathrm{Fo}$ S28:22amPO:P218 S46:22pmPO:P268 $\mathrm{S} 46: 23 \mathrm{am} 12: \mathrm{A} / \mathrm{St}$ $\mathrm{S} 46: 23 \mathrm{pm} 23: \mathrm{A} / \mathrm{St}$ G08:21am05:C/S1 S22:23am14:A/Co G04:22amPO:P249 S17:23amPO:P007 G01:19pmPO:P272 S25:21am08:B/Fo $\mathrm{S} 30: 19 \mathrm{am} 12: \mathrm{B} / \mathrm{Pi}$ G04:23am11:B/Pi $\mathrm{S} 45: 18 \mathrm{am} 06: \mathrm{A} / \mathrm{Co}$ S25:21am04:B/F G08:21pm22:C/S1 G10:21pm25:A/St S39:22pmPO:P343 G01:22am10:A/St S40:22pmPO:P107 G01:22pm29:A/St S25:21am14:B/Fo S25:21am08:B/Fo S22:23am05:A/Co S39:22pmPO:P360 G08:21 am05:C/S1 S14:18pmPO:P014 S40:22am02:A/Fm S46:23am07:A/St $\mathrm{S} 31: 22 \mathrm{pm} 21: \mathrm{A} / \mathrm{Co}$ G08:21pm30:C/S1 S28:22amPO:P220 $\mathrm{S} 25 \cdot 21 \mathrm{am} 08 \cdot \mathrm{B} / \mathrm{Fo}$ G01:22pm30:A/St G01:19pmPO:P263 G01:19pmPO:P280 G05:22pmPO:P055 S10:22amPO:P119 S07:19am04:C/S2 S47:19pmPO:P312 $\mathrm{S} 22: 23 \mathrm{pm} 32: \mathrm{A} / \mathrm{Co}$

Prog. Abs. Author

Code

Prog. Abs. Author

Code

Prog. Abs.

$11 \quad$ A676

11 A799

$\begin{array}{ll}18 & \mathbf{A 4 1 7}\end{array}$

$34 \quad \mathrm{~A} 850$

$39 \quad$ A 317

50 A629

68 A244

$71 \quad \mathrm{~A} 418$

$6 \quad \mathbf{A 4 1 8}$

69 A419

26 A514

63 A608

$46 \quad$ A153

$51 \quad \mathbf{A 4 1 9}$

15 A518

28 A420

65 A456

75 A375

$12 \quad$ A16

29 A420

$37 \quad$ A182

$23 \quad$ A421

34 A882

$5 \quad \mathrm{~A} 142$

$38 \quad \mathrm{~A} 673$

$44 \quad$ A327

$65 \quad$ A591

67 A392

5 A244

55 A672

67 A538

71 A421

76 A326

81 A558

$36 \quad$ A362

74 A412

57 A688

$63 \quad$ A608

$23 \quad \mathrm{~A} 422$

38 A422

$16 \quad$ A587

72 A883

6 A280

$38 \quad \mathbf{A 4 2 3}$

$42 \quad$ A588

$42 \quad \mathbf{A 4 2 3}$

$70 \quad$ A73

46 A153

71 A424

$51 \quad$ A286

$\begin{array}{ll}38 & \mathbf{A 4 2 4}\end{array}$

38 A422

$\begin{array}{ll}74 & \mathbf{A 4 2 5}\end{array}$

$70 \quad$ A777

$36 \quad$ A362

29 A864

$50 \quad \mathbf{4} 25$

76 A456

55 A445

42 A708

$67 \quad$ A789

$38 \quad \mathrm{~A} 422$

51 A419

$23 \quad$ A137

23 A661

58 A426

$62 \quad$ A139

$13 \quad$ A603

$33 \quad$ A226

79 A440

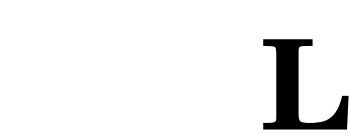

Labat D

Labotka T

Lacan F

Lacan F

lachowski E

Lackey JS

Lacrampe-Couloume $\mathrm{G}$

LaFree ST

Lahaye Y

Laj C

Lal D

Lal DL

Lalande M

Lambert D

Lamy I

Lan C

Lancet D

Lanford WA

Langenhorst $\mathrm{F}$

Langley $\mathrm{S}$

Langmuir C

Langmuir $\mathbf{C H}$

Langmuir $\mathrm{CH}$

Langmuir $\mathrm{CH}$

Langmuir $\mathrm{CH}$

Langmuir D

Lanoil B

Lanphere MA

Lanzirotti A

Lapen TJ

Lapierre $\mathrm{H}$

Lapierre $\mathrm{H}$

Large PR

Larrasoaña JC

Larsen KA

Larsen $\mathrm{O}$

Larsen $\mathrm{O}$

Larson PB

Larsson $\mathrm{H}$

Larsson J

Larter S

Lassen B

Lassiter J

Lassiter JC

Lassiter JC

Latimer J

Laukenmann S

Lauretta DS

Laurie C

Lavastre $\mathrm{V}$

Laverman A

Lavric JV

Law-Wai E

Layne G

Layne G

Layne GD

Layne GD

Lazar B

Lazar B

Lazar B

Le Quéré C

Le Roex AP

le Roux P

Lea D

Lea D

Lea D

Lea D

Lea D

Lear CL

Leckie JO

Lecuyer C

Lecuyer $\mathrm{C}$

Lecuyer

\section{S22:22amPO:P307 \\ S18:21am14:C/S2 \\ $\mathrm{S} 42: 18 \mathrm{am} 11: \mathrm{B} / \mathrm{Fo}$ \\ S42:19amPO:P222 \\ $\mathrm{S} 39: 23 \mathrm{pm} 23: \mathrm{B} / \mathrm{Ja}$ \\ S16:22pmPO:P029}

$\mathrm{S} 33: 18 \mathrm{am} 10: \mathrm{B} / \mathrm{P}$

S39:23am11:B/Ja

S08:22pmPO:P015

S28:22amPO:P218

S46:23pm23:A/St

S46:23pm21:A/St

S36:23amPO:P261

S08:22pmPO:P015

$\mathrm{S} 37: 21 \mathrm{am} 05: \mathrm{B} / \mathrm{Ja}$

G01:19pmPO:P273

S06:19am11:C/S2

S17:22pm25:C/A2

G06:23pm21:C/S2

S10:23am09:C/A1

G04:23am10:B/Pi

S11:18amPO:P052

S14:19am03:C/A2

S11:19am03:C/A1

S10:22pm22:C/A1

S10:23am01:C/A1

G07:19am10:B/Ja

$\mathrm{S} 35: 21 \mathrm{am} 05: \mathrm{B} / \mathrm{Pi}$

S16:23am03:C/A2

$\mathrm{S} 48: 18 \mathrm{pm} 23: \mathrm{B} / \mathrm{Ja}$

G01:22am13:A/St

S13:18am13:C/A2

G05:21pm27:C/A1

S17:23amPO:P011

S26:23amPO:P204

S47:19pmPO:P311

G04:22amPO:P253

S41:23am13:A/Fm

S41:23am06:A/Fm

S06:19am14:C/S2

S37:21 am04:B/Ja

S34:22am05:B/Ja

G05:22pmPO:P056

S10:23am05:C/A1

G05:21 am09:C/A1

S10:23pm24:C/A1

S23:19pmPO:P206

S30:18amPO:P253

$\mathrm{S} 44: 18 \mathrm{am} 14: \mathrm{A} / \mathrm{St}$

S14:19pm23:C/A2

S39:22pmPO:P350

S19:22pm26:C/S2

S34:23amPO:P315

$\mathrm{S} 31: 22 \mathrm{am} 06: \mathrm{A} / \mathrm{Co}$

S11:18pm27:C/A1

S47:19am13:A/St

S49:19pm22:A/Fm

S17:22am08:C/A2

S49:19pm30:A/Fm

S31:22am09:A/Co

G04:22amPO:P238

S23:18pm27:B/Fo

S15:18am07:C/A1

S12:19pmPO:P036

S42:18am08:B/Fo

S24:19pm21:B/Fo

$\mathrm{S} 24: 19 \mathrm{pm} 31: \mathrm{B} / \mathrm{Fo}$ 
Goldschmidt 2002 Index

\begin{tabular}{|c|c|c|c|c|c|c|c|c|c|c|c|}
\hline Author & Code & Prog. & Abs. & Author & Code & Prog. & Abs. & Author & Code & Prog. & Abs. \\
\hline Libourel G & G08:21am07:C/S1 & 36 & A781 & Luckscheiter B & $\mathrm{S} 39: 22 \mathrm{pmPO}: \mathrm{P} 344$ & 70 & A93 & Manceau A & $\mathrm{S} 37: 21 \mathrm{pm} 28: \mathrm{B} / \mathrm{Ja}$ & 45 & A163 \\
\hline Libourel G & S08:21am06:C/A2 & 37 & A225 & Ludden J & S11:19am13:C/A1 & 14 & A594 & Mancktelow N & G01:19pmPO:P267 & 23 & A342 \\
\hline Libourel G & S41:22amPO:P101 & 71 & A144 & Ludden $\mathrm{J}$ & $\mathrm{S} 41: 23 \mathrm{am} 10: \mathrm{A} / \mathrm{Fm}$ & 76 & A652 & Mancktelow N & G06:23am04:C/S2 & 72 & A646 \\
\hline Licciardi J & S46:23am07:A/St & 76 & A456 & Lüders V & S17:23amPO:P005 & 63 & A463 & Mandengyogo M & G07:18pmPO:P324 & 24 & A 123 \\
\hline Liebetrau V & S22:22amPO:P301 & 65 & A456 & Ludwig KR & G01:22pm26:A/St & 51 & A463 & Mandernack K & $\mathrm{S} 41: 23 \mathrm{pm} 25: \mathrm{A} / \mathrm{Fm}$ & 81 & A 110 \\
\hline Liebske C & S03:22pm24:C/S1 & 52 & A654 & Lugolobi F & S24:18pmPO:P216 & 31 & A772 & Manes F & G07:18pmPO:P339 & 25 & A479 \\
\hline Lienemann $\mathrm{C}$ & $\mathrm{S} 30: 19 \mathrm{pm} 29: \mathrm{B} / \mathrm{Pi}$ & 22 & A 256 & Luhr J & S12:19pmPO:P042 & 28 & A848 & Manfra L & G07:18pmPO:P339 & 25 & A479 \\
\hline Liermann L & $\mathrm{S} 36: 21 \mathrm{pm} 30: \mathrm{B} / \mathrm{Pi}$ & 44 & A100 & Lumpkin G & S39:23am05:B/Ja & 75 & A464 & Mangelsdorf K & S33:18am04:B/Pi & 4 & A342 \\
\hline Lifton $\mathbf{N}$ & S46:23am04:A/St & 76 & A457 & Lundstrom C & S11:19pm27:C/A1 & 19 & A464 & Mangelsdorf K & S24:19am06:B/Fo & 15 & A480 \\
\hline Lilienthal S & G04:22amPO:P233 & 57 & A94 & Lunine $\mathbf{J}$ & S46:23pm30:A/St & 81 & A461 & Mangini A & G01:19pmPO:P274 & 23 & A482 \\
\hline Lin A & G01:19pmPO:P268 & 23 & A358 & Lustrino M & S14:18pmPO:P004 & 29 & A242 & Mangini A & S23:19pmPO:P202 & 30 & A141 \\
\hline Lin $L$ & S33:18am11:B/Pi & 4 & A457 & Lustrino M & G05:22pmPO:P058 & 58 & A465 & Mangini A & S23:19pmPO:P209 & 30 & A685 \\
\hline Lin L & S33:18am10:B/Pi & 4 & A706 & Luttge A & S48:18am06:B/Ja & 6 & A32 & Mangini A & S30:18amPO:P253 & 31 & A434 \\
\hline Lindsay J & S07:18am11:C/S2 & 3 & A101 & Luttge A & $\mathrm{S} 48: 18 \mathrm{am} 05: \mathrm{B} / \mathrm{Ja}$ & 6 & A63 & Mangini A & S42:19amPO:P221 & 32 & A233 \\
\hline Lindsley D & S17:22am03:C/A2 & 47 & A549 & Luttge A & S48:18am07:B/Ja & 6 & A150 & Mangini A & S28:23pm24:B/Fo & 80 & A480 \\
\hline Linsley B & S28:23am06:B/Fo & 75 & A649 & Luttge A & S48:19pmPO:P356 & 34 & A232 & Mangini A & $\mathrm{S} 28: 23 \mathrm{pm} 28: \mathrm{B} / \mathrm{Fo}$ & 80 & A733 \\
\hline Lippmann J & $\mathrm{S} 33: 18 \mathrm{am} 11: \mathrm{B} / \mathrm{Pi}$ & 4 & A457 & Luttge A & S48:19pmPO:P362 & 34 & A465 & Mango F & S34:22am09:B/Ja & 49 & A481 \\
\hline Lippmann $\mathbf{J}$ & S40:21pm28:A/Fm & 45 & A458 & Luttge A & S36:23amPO:P260 & 68 & A113 & Manning A & $\mathrm{S} 31: 22 \mathrm{am} 05: \mathrm{A} / \mathrm{Co}$ & 49 & A727 \\
\hline Lippolt HJ & G01:19pmPO:P284 & 23 & A692 & Luttge A & $\mathrm{S} 39: 23 \mathrm{pm} 28: \mathrm{B} / \mathrm{Ja}$ & 80 & A351 & Manning C & $\mathrm{S} 18: 21 \mathrm{am} 10: \mathrm{C} / \mathrm{S} 2$ & 37 & A551 \\
\hline Litasov K & G09:18am10:A/Fm & 2 & A458 & Luxton TP & $\mathrm{S} 48: 18 \mathrm{pm} 32: \mathrm{B} / \mathrm{Ja}$ & 11 & A759 & Manning D & S34:22am10:B/Ja & 49 & A481 \\
\hline Littke R & G04:22amPO:P244 & 57 & A534 & Luz B & S42:18am14:B/Fo & 5 & A466 & Mao H & G09:18pm24:A/Fm & 7 & A666 \\
\hline Litvin V & S17:22am03:C/A2 & 47 & A549 & Luzi S & $\mathrm{S} 38: 22 \mathrm{pm} 27: \mathrm{B} / \mathrm{Ja}$ & 56 & A883 & Marbach T & G01:19pmPO:P274 & 23 & A482 \\
\hline Litvin Y & S11:18amPO:P051 & 27 & A661 & Lv Z & S41:22amPO:P102 & 71 & A466 & Marchal O & S24:19am07:B/Fo & 15 & A482 \\
\hline Litvin Y & S03:23pmPO:P142 & 61 & A377 & Lvov S & S18:21am07:C/S2 & 37 & A467 & Marchesini D & S07:18am07:C/S2 & 3 & A830 \\
\hline Litwiller E & $\mathrm{S} 38: 22 \mathrm{pm} 23: \mathrm{B} / \mathrm{Ja}$ & 56 & A632 & Lyakhovsky V & $\mathrm{S} 11: 19 \mathrm{pm} 25: \mathrm{C} / \mathrm{A} 1$ & 19 & A448 & Marchitto T & S42:18am01:B/Fo & 5 & A483 \\
\hline Liu C & G07:19pm22:B/Ja & 18 & A849 & Lynch-Stieglitz J & S24:18pmPO:P213 & 31 & A467 & Marchitto T & S24:18pmPO:P213 & 31 & A467 \\
\hline Liu C & G03:19pmPO:P239 & 24 & A820 & Lynch-Stieglitz J & $\mathrm{S} 28: 23 \mathrm{am} 07: \mathrm{B} / \mathrm{Fo}$ & 75 & A413 & Marchitto T & $\mathrm{S} 28: 23 \mathrm{am} 07: \mathrm{B} / \mathrm{Fo}$ & 75 & A413 \\
\hline Liu C & G04:22amPO:P239 & 57 & A283 & Lyons J & S02:18pm23:C/S1 & 7 & A468 & Marcuello A & S19:23amPO:P161 & 64 & A483 \\
\hline Liu C & G05:22pmPO:P070 & 59 & A872 & Lyons J & S07:18pm25:C/S2 & 8 & A655 & Marcus R & S02:18pm21:C/S1 & 7 & A484 \\
\hline Liu C & S21:22pmPO:P287 & 65 & A306 & Lyons T & S07:18pm23:C/S2 & 8 & A468 & Marechal CN & S41:23pm28:A/Fm & 81 & A484 \\
\hline Liu C & S22:22amPO:P302 & 65 & A459 & Lysenko O & G04:22amPO:P243 & 57 & A469 & Marei A & $\mathrm{S} 38: 22 \mathrm{pm} 30: \mathrm{B} / \mathrm{Ja}$ & 56 & A804 \\
\hline Liu C & S22:22amPO:P303 & 65 & A471 & Lysenko O & G04:22amPO:P252 & 57 & A725 & Marinho MM & G01:19pmPO:P278 & 23 & A647 \\
\hline Liu C & S21:22pmPO:P293 & 65 & A851 & & & & & Marinho MM & G01:22pm27:A/St & 51 & A640 \\
\hline Liu C & S41:22amPO:P102 & 71 & A466 & & & & & Mark R & $\mathrm{S} 41: 23 \mathrm{am} 08: \mathrm{A} / \mathrm{Fm}$ & 76 & A 838 \\
\hline Liu C & S41:22amPO:P105 & 71 & A873 & & & & & Markey R & $\mathrm{S} 45: 18 \mathrm{am} 07: \mathrm{A} / \mathrm{Co}$ & 6 & A738 \\
\hline Liu J & G09:18am02:A/Fm & 2 & $\mathbf{A}$ & & & & & Markey RJ & S45:18am09:A/Co & 6 & A308 \\
\hline Liu J & S15:19amPO:P062 & 29 & A295 & & & & & Märki M & S30:19am08:B/Pi & 16 & A485 \\
\hline Liu J & G08:21pm24:C/S1 & 42 & A861 & & & & & Marks L & S28:22amPO:P219 & 67 & A640 \\
\hline Liu J & G05:22pmPO:P057 & 58 & A459 & & & & & Marmo J & S07:19pmPO:P171 & 27 & A735 \\
\hline Liu J & S41:22amPO:P102 & 71 & A466 & & & & & Marques LS & G01:19pmPO:P278 & 23 & A647 \\
\hline Liu M & G06:23am08:C/S2 & 72 & A159 & & & & & Marriott C & S24:19am14:B/Fo & 15 & A485 \\
\hline Liu S & $\mathrm{S} 44: 18 \mathrm{am} 05: \mathrm{A} / \mathrm{St}$ & 5 & A 850 & & & & & Marrocchi Y & S40:22pmPO:P108 & 71 & A486 \\
\hline Liu W & $\mathrm{S} 18: 21 \mathrm{am} 01: \mathrm{C} / \mathrm{S} 2$ & 37 & A845 & & & & & Marrocchino E & S16:22pmPO:P030 & 63 & A486 \\
\hline Liu X & G09:18am08:A/Fm & 2 & A236 & Ma Y & S22:22amPO:P303 & 65 & A471 & Marshall J & $\mathrm{S} 24: 19 \mathrm{pm} 23: \mathrm{B} / \mathrm{Fo}$ & 21 & A207 \\
\hline Liu X & S11:18amPO:P054 & 27 & A749 & Maas R & G03:19pmPO:P228 & 24 & A352 & Martens CS & $\mathrm{S} 40: 21 \mathrm{pm} 31: \mathrm{A} / \mathrm{Fm}$ & 45 & A487 \\
\hline Liu Y & G08:21pm24:C/S1 & 42 & A861 & Macalady J & $\mathrm{S} 22: 23 \mathrm{pm} 25: \mathrm{A} / \mathrm{Co}$ & 79 & A49 & Marti K & S02:19pm27:C/S1 & 18 & A487 \\
\hline Liu Y & G05:22pmPO:P057 & 58 & A459 & Macambira MJB & G01:19pmPO:P278 & 23 & A647 & Marti K & S03:23am04:C/S1 & 73 & A490 \\
\hline Liu Z & S24:18pmPO:P213 & 31 & A467 & Macaulay J & $\mathrm{S} 32: 18 \mathrm{pm} 26: \mathrm{B} / \mathrm{Pi}$ & 10 & A716 & Martin EE & S42:19amPO:P224 & 32 & A677 \\
\hline Livermore RA & S44:19amPO:P298 & 33 & A246 & Macdougall D & S24:19am08:B/Fo & 15 & A181 & Martin P & S24:19pm31:B/Fo & 21 & A488 \\
\hline Lo C & G01:19pmPO:P273 & 23 & A429 & Macera P & S10:22amPO:P124 & 62 & A264 & Martin PL & G10:22pmPO:P278 & 60 & A694 \\
\hline Lo Giudice A & S44:19amPO:P302 & 33 & A617 & MacGregor BJ & S35:21am14:B/Pi & 39 & A471 & Martin S & S36:21pm27:B/Pi & 44 & A488 \\
\hline Loesekann T & $\mathrm{S} 35: 21 \mathrm{am} 03: \mathrm{B} / \mathrm{Pi}$ & 39 & A543 & Machado A & $\mathrm{S} 44: 18 \mathrm{pm} 23: \mathrm{A} / \mathrm{St}$ & 10 & A472 & Martin T & S07:19pmPO:P166 & 27 & A129 \\
\hline Logan G & $\mathrm{S} 43: 21 \mathrm{am} 04: \mathrm{A} / \mathrm{St}$ & 40 & A697 & Machado N & S44:18pm23:A/St & 10 & A472 & Martin W & $\mathrm{S} 39: 23 \mathrm{pm} 30: \mathrm{B} / \mathrm{Ja}$ & 80 & A602 \\
\hline Logan G & $\mathrm{S} 41: 23 \mathrm{am} 07: \mathrm{A} / \mathrm{Fm}$ & 76 & A288 & Machesky M & S37:23amPO:P331 & 69 & A472 & Martin-Garin A & $\mathrm{G} 04: 23 \mathrm{pm} 29: \mathrm{B} / \mathrm{Pi}$ & 77 & A592 \\
\hline Logvinova A & G09:19amPO:P127 & 26 & A635 & MacIsaac C & $\mathrm{S} 24: 19 \mathrm{am} 08: \mathrm{B} / \mathrm{Fo}$ & 15 & A181 & Martinez I & S18:21am09:C/S2 & 37 & A489 \\
\hline Lojen S & G03:19pmPO:P231 & 24 & A460 & Mackenzie FT & G08:19pmPO:P156 & 25 & A 247 & Martinez I & S09:22am04:C/A1 & 47 & A715 \\
\hline Lojen S & S23:19pmPO:P203 & 30 & A190 & Mackenzie FT & $\mathrm{G} 04: 22 \mathrm{pm} 21: \mathrm{B} / \mathrm{Pi}$ & 51 & A449 & Martinez-Ruiz F & S26:22pm24:B/Fo & 54 & A489 \\
\hline Long X & G09:18am02:A/Fm & 2 & $\mathrm{~A}$ & Mackwell S & S10:23am11:C/A1 & 73 & $\mathbf{A 4 7 3}$ & Martinez-Ruiz F & S04:23amPO:P147 & 61 & A644 \\
\hline Longfang L & S17:23amPO:P014 & 63 & A876 & Mäder U & $\mathrm{S} 19: 22 \mathrm{am} 02: \mathrm{C} / \mathrm{S} 2$ & 48 & A726 & Martrat B & $\mathrm{S} 24: 19 \mathrm{am} 07: \mathrm{B} / \mathrm{Fo}$ & 15 & A482 \\
\hline Longinelli A & G03:19pmPO:P227 & 24 & A165 & Mäder U & $\mathrm{S} 39: 23 \mathrm{pm} 22: \mathrm{B} / \mathrm{Ja}$ & 80 & A592 & Marty B & S02:18pm29:C/S1 & 7 & A169 \\
\hline Looslî HH & S31:22am10:A/Co & 49 & A460 & Mader UK & S19:22am01:C/S2 & 48 & A473 & Marty B & $\mathrm{S} 12: 18 \mathrm{pm} 24: \mathrm{C} / \mathrm{A} 2$ & 9 & A 329 \\
\hline López-Martìnez M & $\mathrm{G} 01: 22 \mathrm{pm} 21: \mathrm{A} / \mathrm{St}$ & 51 & A826 & Madyukov I & S17:23amPO:P006 & 63 & A590 & Marty B & $\mathrm{S} 21: 21 \mathrm{pm} 27: \mathrm{A} / \mathrm{Co}$ & 44 & A603 \\
\hline Lorand J & S11:18pm30:C/A1 & 8 & A633 & Maeda S & S14:18pmPO:P013 & 29 & A858 & Marty B & $\mathrm{S} 27: 22 \mathrm{am} 07: \mathrm{B} / \mathrm{Fo}$ & 48 & A12 \\
\hline Lorand $\mathrm{J}$ & S15:19amPO:P059 & 29 & A155 & Maffei K & S10:22amPO:P124 & 62 & A264 & Marty B & S40:22pmPO:P108 & 71 & A486 \\
\hline Lorenz R & $\mathrm{S} 46: 23 \mathrm{pm} 30: \mathrm{A} / \mathrm{St}$ & 81 & A461 & Maggi V & S27:22am14:B/Fo & 48 & A175 & Marty B & S40:22pmPO:P111 & 71 & A864 \\
\hline Lösekann T & S35:19amPO:P245 & 32 & A407 & Magloughlin J & S20:19am09:A/Co & 15 & A474 & Marty B & S03:23am04:C/S1 & 73 & A490 \\
\hline Losh S & S34:22am11:B/Ja & 49 & A124 & Magna T & S44:19amPO:P300 & 33 & A474 & Marty B & S46:23am08:A/St & 76 & A267 \\
\hline Lott III D & S40:22am02:A/Fm & 50 & A425 & Mahara Y & S31:22am13:A/Co & 49 & A475 & Maruyama S & S08:21am08:C/A2 & 37 & A709 \\
\hline \multicolumn{4}{|c|}{ Loukola-Ruskeeniemi K } & Maher K & S41:23am06:A/Fm & 76 & A432 & Marzoli A & S11:18amPO:P050 & 27 & A625 \\
\hline & S07:18am15:C/S2 & 3 & A461 & Maheshwari A & G03:19pmPO:P232 & 24 & A475 & Marzoli A & S15:19amPO:P064 & 29 & A490 \\
\hline Louvat D & S39:22pmPO:P358 & 70 & A742 & Mahlen NJ & G01:22am13:A/St & 46 & A431 & Masarik J & S46:23am05:A/St & 76 & A491 \\
\hline Love A & $\mathrm{S} 31: 22 \mathrm{pm} 21: \mathrm{A} / \mathrm{Co}$ & 55 & A445 & Mahoney J & G07:19am10:B/Ja & 12 & A430 & Mason PR & S15:18am09:C/A1 & 4 & A579 \\
\hline Love E & S39:22pmPO:P364 & 70 & A879 & Maia M & G05:21am02:C/A1 & 36 & A322 & Mason PR & S11:19pm29:C/A1 & 19 & A54 \\
\hline Love G & S05:19pm26:C/S2 & 19 & A825 & Maier R & S36:22am10:B/Pi & $\mathbf{5 0}$ & A476 & Mason PR & S14:19pm30:C/A2 & 20 & A324 \\
\hline Love G & $\mathrm{S} 34: 22 \mathrm{am} 05: \mathrm{B} / \mathrm{Ja}$ & 49 & A25 & Major C & G03:19pmPO:P233 & 24 & A476 & Massimo T & S15:19amPO:P067 & 29 & A613 \\
\hline Lowe DR & S07:19pmPO:P169 & 27 & A523 & Majzlan J & G07:18pmPO:P338 & 25 & A477 & Masson-Delmotte V & S28:23am09:B/Fo & 75 & A832 \\
\hline Lowenstein $\mathrm{T}$ & S22:23am12:A/Co & 74 & A282 & Makarenko G & G08:21pm32:C/S1 & 42 & A477 & Masuda T & S18:22pmPO:P151 & 64 & A491 \\
\hline Lowry D & G05:21am11:C/A1 & 36 & A462 & Makishima A & $\mathrm{S} 41: 22 \mathrm{pm} 24: \mathrm{A} / \mathrm{Fm}$ & 56 & A129 & Matenaar I & S33:19amPO:P243 & 32 & A643 \\
\hline Lowry GV & G07:19am08:B/Ja & 12 & A399 & Malavergne V & $\mathrm{S} 09: 22 \mathrm{am} 04: \mathrm{C} / \mathrm{A} 1$ & 47 & A715 & Matera V & G04:23am05:B/Pi & 72 & A623 \\
\hline $\mathrm{Lu} \mathrm{Y}$ & G05:22pmPO:P040 & 58 & A368 & Malfère J & S10:22amPO:P129 & 62 & A478 & Mathew K & S03:23am04:C/S1 & 73 & A490 \\
\hline $\mathrm{Lu} \mathrm{ZT}$ & $\mathrm{S} 31: 22 \mathrm{pm} 22: \mathrm{A} / \mathrm{Co}$ & 55 & A748 & Malitch K & S11:19am14:C/A1 & 14 & A478 & Mathur E & $\mathrm{S} 35: 21 \mathrm{pm} 21: \mathrm{B} / \mathrm{Pi}$ & 44 & A390 \\
\hline Lucchini F & G07:19pm26:B/Ja & 18 & A664 & Malmström M & G06:23pm21:C/S2 & 77 & A479 & Mathur R & $\mathrm{S} 36: 22 \mathrm{am} 14: \mathrm{B} / \mathrm{Pi}$ & 50 & A654 \\
\hline
\end{tabular}


Goldschmidt 2002 Index

Author

Matisoff G

Matmon A

Matrajt G

Matsuda J

Matsumoto K

Matsumoto T

Matsuno K

Mattey D

Mattey DP

Matthai S

Matthews A

Matthews A

Matthews A

Matthews A

Matthews A

Matthews I

Mattielli N

Mattox T

Matveev Y

Mauclaire $\mathbf{L}$

Maurette M

Maurice P

Mavrocordatos D

Mawson R

Maxshima A

Mayanovic RA

Mayer B

Mayer L

Mayer U

Mayer UK

Mayes M

Mayewski P

Mazaud A

Mazumdar A

Mazzoleni $\mathrm{P}$

Mazzucchelli M

McBeth J

McCall PJ

McCarthy M

McConnaughey $\mathbf{T}$

McCoy TJ

McCulloch M

McCulloch M

McCulloch M

McCulloch M

McCulloch M

McCulloch M

McCulloch MT

McCulloch MT

McDade P

McDade P

McDermott $F$

McDermott F

McDermott F

McDonough W

McDonough W

McFadden $\mathrm{M}$

McGarry $S$

McGrail P

McGregor HV

McInnes B

McIntyre K

McKay DS

McKeegan K

McKeegan K

McKeegan K

McKeegan K

McKeegan KD

McKenzie D

McKenzie D

McKenzie D

McKenzie JA

McKenzie JA

McKenzie JA

McKenzie JA

McKenzie JA

McKenzie JA

McKenzie JA

McKinley IG

McKinley JP

McLean J

McLelland J

McManus J
Code

S39:22pmPO:P356 S21:21am11:A/Co S05:19pm27:C/S2 S40:22pmPO:P109 S27:23amPO:P222 S40:22pmPO:P109 S05:19pm29:C/S2 G03:21pm30:B/Fo G06:23am06:C/S2 S19:23amPO:P157 G03:21pm28:B/Fo S19:22am14:C/S2 S26:23amPO:P202 G06:23am06:C/S2 S41:23am12:A/Fm S22:23am10:A/Co S11:19am01:C/A S08:21am03:C/A2 S11:18amPO:P051 S35:21am11:B/Pi S05:19pm21:C/S2 S36:22am04:B/Pi S49:18pmPO:P105 S23:19pmPO:P201 S41:23am03:A/Fm S18:21am11:C/S2

S38:23amPO:P339 G04:23pm24:B/Pi S19:22am11:C/S2 S30:19am13:B/Pi S19:22am08:C/S2 S43:22pmPO:P267 S28:22amPO:P218 S07:19am02:C/S2 G01:19pmPO:P288 S11:18pm29:C/A1 S35:19amPO:P246 G04:23pm26:B/P S43:21am03:A/St

S49:19pm26:A/Fm G08:21 am04:C/S S44:18pm26:A/St G07:19pm21:B/Ja S24:19pm26:B/Fo G03:19pmPO:P237 S44:19amPO:P299 S44:19amPO:P301 S29:19pm23:A/St $\mathrm{S} 28: 23 \mathrm{am} 12: \mathrm{B} / \mathrm{Fo}$ S11:19pm26:C/A1 S15:19amPO:P065 G05:21am03:C/A1 G03:21pm25:B/Fo S28:23am 14:B/Fo S13:18am08:C/A2 S15:18am04:C/A1 S30:18amPO:P248 G03:21pm28:B/Fo S39:23pm28:B/Ja S28:23am12:B/Fo G01:22am04:A/St S42:19amPO:P217 G04:23am01:B/P S07:18pm27:C/S2 S07:18pm25:C/S2 G03:19pmPO:P237 $\mathrm{S} 35: 21 \mathrm{am} 06: \mathrm{B} / \mathrm{Pi}$ S02:19am02:C/S S11:18pm21:C/A1 S12:18pm31:C/A2 G05:21 am10:C/A1 S49:19am05:A/Fm S24:18pmPO:P215 S33:19amPO:P242 S49:18pmPO:P108 $\mathrm{S} 35: 21 \mathrm{am} 11: \mathrm{B} / \mathrm{Pi}$ $\mathrm{S} 28: 23 \mathrm{am} 08: \mathrm{B} / \mathrm{Fo}$ G04:23pm26:B/Pi S39:22pmPO:P351 S48:18pm26:B/Ja

$\mathrm{S} 36 \cdot 22 \mathrm{am} 11 \cdot \mathrm{B} / \mathrm{Pi}$ G01:22am12:A/St S41:22pm27:A/Fm

Prog. Abs. Author

\section{$70 \quad$ A671}

McManus JF

McPhail DB

1 A492

Meckenstock R

Mehl L

$67 \quad$ A223

Meibom A

71 A492 Meier M

19 A493 Meierhenrich U

41 A493 Meile C

72 A44 Meile C

64 A269

41 A500

$48 \quad \mathrm{~A} 254$

66 A49

72 A44

$\begin{array}{ll}6 & \mathrm{~A} 494\end{array}$

$\begin{array}{ll}4 & \text { A322 } \\ 14 & \text { A719 }\end{array}$

$37 \quad$ A53

$27 \quad$ A661

$39 \mathbf{A 4 9 4}$

$\begin{array}{ll}19 & \mathbf{A 4 9 5}\end{array}$

$\begin{array}{ll}50 & \mathbf{A 4 9 5}\end{array}$

34 A566

A23

$76 \quad$ A298

$37 \quad \mathbf{A 4 9 6}$

69 A695

$\begin{array}{ll}77 & \mathbf{A 4 9 7}\end{array}$

$48 \quad \mathbf{A 4 9 6}$

6 A616

$48 \quad \mathrm{~A} 300$

71 A418

67 A538

$\begin{array}{ll}13 & \mathbf{A 4 9 7}\end{array}$

$23 \quad$ A786

8 A143

$32 \quad \mathrm{~A} 498$

$77 \quad$ A522

$40 \quad$ A622

$\begin{array}{ll}22 & \mathbf{A 4 9 8}\end{array}$

36 A821

$10 \quad$ A72

$18 \quad \mathbf{4 9 9}$

21 A255

24 A784

33 A399

$33 \quad$ A527

21 A531

75 A501

19 A84

$\begin{array}{ll}29 & \text { A499 }\end{array}$

36 A279

$41 \mathbf{A 5 0 0}$

75 A46

3 A867

$4 \quad \mathrm{~A} 103$

$31 \quad \mathrm{~A} 2$

$41 \mathrm{A500}$

$80 \quad \mathrm{~A} 35$

$\begin{array}{ll}75 & \text { A501 }\end{array}$

$46 \quad$ A219

32 A7

72 A781

8 A225

$8 \quad \mathrm{~A} 655$

24 A784

39 A571

2 A131

8 A501

9 A316

$36 \quad$ A747

17 A808

$31 \quad \mathrm{~A} 582$

32 A506

34 A801

39 A494

75 A22

$77 \quad$ A522

$70 \quad \mathrm{~A} 502$

$11 \mathbf{A 5 0 2}$

$50 \quad$ A286

46 A144

$56 \mathbf{A 5 0 3}$

Meinert LD

Meisel T

Meisel T

Meisel T

Meister $\mathrm{P}$

Meister P

Meixner A

Meixner A

Mel'gunov $\mathrm{M}$

Mel'gunova E

Melluso L

Melluso L

Melnik O

Melosh J

Mendlovitz HP

Menez B

Menguy N

Menguy $\mathrm{N}$

Menton MC

Menuge J

Menzies M

Mercier F

Mercier J

Mercier JC

Mergenthaler B

Mergoil J

Merkle RK

Merkylueva N

Mernagh T

Mertz D

Meshik A

Meshik AP

Meshik APM

Metcalfe R

Metcalfe R

Meth C

Metrich N 
Morten L

Mörth C

Mortimer G

Mortimer G

Mory A

Moser D

Moser J

Mostefaoui S

Mostefaoui S

Motelica-Heino M

Mottl M

Mottl M

Mottl MJ

Mouatt J

Mountain B

Mountain BW

Moura JM

Mroczek E

Mucci A

Mucci A

Mucci A

Muchez P

Muehlenbachs K

Mueller A

Mueller W

Muentener O

Mukasa S

Mukhopadhyay S

Mulch A

Mulch A

Mulitza S

Mullane E

Müller A

Müller AB

Müller B

Müller B

Müller B

Müller G

Muller M

Mullins H

Mullis J

Mumma M

Munday D

Munday D

Mundil R

Mungall J

Mungall JE

Munha J

Münker C

Münker C

Münker C

Münker C

Münker C

Münker C

Münker C

Munoz Caro G

Muntener O

Murakami M

Murakami M

Murakami T

Murayama M

Muri G

Murphy D

Murrell M

Murton B

Murton B

Muscheler R

Mushkin A

Musselwhite D

Mustin C

Muti A

Mutschke $\mathrm{H}$

Mutter A

Mutter A

Myers JD

Myneni S

Myneni S
S10:22amPO:P124 G07:18pmPO:P322 S44:18pm26:A/S S44:19amPO:P301

S04:23pm28:C/S1

$\mathrm{S} 40: 21 \mathrm{pm} 28: \mathrm{A} / \mathrm{Fm}$

S44:18pm30:A/St

S02:19am08:C/S1

S01:19amPO:P145

S30:19pm21:B/Pi

S13:19amPO:P019

$\mathrm{S} 19: 22 \mathrm{am} 12: \mathrm{C} / \mathrm{S} 2$

S13:18am06:C/A2

S40:22am03:A/Fm

S18:21pm28:C/S2

G04:23am02:B/Pi

$\mathrm{S} 40: 21 \mathrm{pm} 31: \mathrm{A} / \mathrm{Fm}$

S18:21pm30:C/S2

S49:19am03:A/Fm

G09:19amPO:P111

G09:19amPO:P130

G01:19pmPO:P283

S33:18am09:B/Pi

S24:18pmPO:P214

S29:19pm23:A/St

S15:19amPO:P068

S16.23am11:C/A2

S01:19amPO:P146

S20:19am13:A/Co

S20:19am14:A/Co

S24:19am04:B/Fo

G08:21am15:C/S1

S24:18pmPO:P211

G04:22amPO:P244

$\mathrm{S} 30: 19 \mathrm{am} 07: \mathrm{B} / \mathrm{P}$

$\mathrm{S} 30: 19 \mathrm{am} 08: \mathrm{B} / \mathrm{P}$

S30:18amPO:P254

$\mathrm{S} 32: 18 \mathrm{pm} 27: \mathrm{B} / \mathrm{Pi}$

S18:21pm28:C/S2

S30:18amPO:P248

G06:22pmPO:P170

S01:18am14:C/S1

S44:18am03:A/St

S14:19pm27:C/A2

G01:22pm26:A/St

S17:22pm26:C/A2

S13:18am14:C/A2

G05:22pmPO:P066

S45:18am 13:A/Co

$\mathrm{S} 02: 19 \mathrm{pm} 26: \mathrm{C} / \mathrm{S}$

S03.22am09.C/S 1

$\mathrm{S} 03: 22 \mathrm{pm} 28: \mathrm{C} / \mathrm{S}$

S03:22pm30:C/S1

S10:22amPO:P118

S10:23am14:C/A1

S05:19pm31:C/S2

S11:19am06:C/A1

G01:19pmPO:P275

G01:22am01:A/St

S07:18pm32:C/S2

S34:23amPO:P318

S30:19am06:B/Pi

S10:23am13:C/A1

S16:23am10:C/A2

S11:18amPO:P047

G05:22pmPO:P066

S28:22amPO:P218

S16:23am07:C/A2

G08:21am02:C/S1

G04:23pm29:B/Pi

$\mathrm{S} 38: 22 \mathrm{pm} 29: \mathrm{B} / \mathrm{J}$

S01:19amPO:P147

S48:18am11:B/Ja

S48:19pmPO:P363

S14:18pmPO:P006

S32:18pm32:B/P

S36:22am 12:B/Pi
62 A264

$24 \quad$ A87

$10 \quad$ A72

$33 \quad$ A527

8 A283

45 A458

0 A506

12 A401

26 A528

22 A172

$28 \quad \mathrm{~A} 670$

$48 \quad$ A520

A528

$50 \mathbf{A 5 2 9}$

43 A533

72 A529

45 A487

$43 \quad \mathbf{A 5 3 0}$

7 A579

25 A138

6 A807

23 A683

$\begin{array}{ll}4 & \mathbf{A 4 8}\end{array}$

31 A530

$21 \mathbf{A 5 3 1}$

29 A671

44 A35

26 A531

15 A 154

$15 \quad \mathbf{5 3 3 2}$

$15 \quad \mathbf{A 5 3 2}$

$\mathbf{3 6}$
$\mathbf{4 5 3 3}$

31 A299

57 A534

16 A253

16 A485

31 A632

10 A395

$43 \quad \mathbf{A 5 3 3}$

31 A2

59 A405

$2 \quad \mathbf{A 5 3 4}$

5 A771

$20 \mathbf{A 5 3 5}$

51 A463

53 A 308

$3 \mathbf{A 5 3 5}$

58 A765

6 A677

18 A844

$46 \quad$ A510

52 A404

52 A536

62 A108

73 A597

19 A505

$14 \mathbf{A 5 3 6}$

$23 \quad$ A537

46 A760

$8 \begin{array}{ll}\mathbf{A 5 3 7}\end{array}$

68 A750

$16 \quad$ A812

$73 \quad \mathbf{A 5 3 8}$

$74 \quad$ A284

$27 \quad$ A239

58 A765

67 A538

$74 \quad$ A539

$36 \quad \mathbf{A 5 3 9}$

77 A592

56 A589

26 A540

$6 \quad \mathbf{A 5 4 0}$

$34 \quad$ A678

29 A553

$10 \quad \mathbf{5 4 1}$

50 A541

$\mathbf{N}$

Nabelek P G06:23am08:C/S2

S35:19amPO:P245

S35:21am03:B/Pi

G09:18pm22:A/Fm

$\mathrm{S} 41: 23 \mathrm{am} 08: \mathrm{A} / \mathrm{Fm}$

S02:19am08:C/S1

S02:19am14:C/S1

G08:21pm29:C/S

$\mathrm{S} 12: 18 \mathrm{pm} 23: \mathrm{C} / \mathrm{A} 2$

$\mathrm{S} 40: 21 \mathrm{am} 07: \mathrm{A} / \mathrm{Fm}$

S40:21am12:A/Fm

S40:22am10:A/Fm

G03:21pm24:B/Fo

S44:18pm27:A/St

S24:19am10:B/Fo

$\mathrm{S} 24: 19 \mathrm{am} 11: \mathrm{B} / \mathrm{Fo}$

$\mathrm{S} 41: 22 \mathrm{pm} 27: \mathrm{A} / \mathrm{Fm}$

$\mathrm{S} 41: 22 \mathrm{pm} 26: \mathrm{A} / \mathrm{Fm}$

$\mathrm{S} 39: 23 \mathrm{pm} 29: \mathrm{B} / \mathrm{Ja}$

$\mathrm{S} 48: 18 \mathrm{am} 15: \mathrm{B} / \mathrm{Ja}$

S14:18pmPO:P013

S14:18pmPO:P007

S40:22am12:A/Fm

S40:22pmPO:P106

S41:23am04:A/Fm

S14:18pmPO:P014

S08:21 am08:C/A2

S01:18am09:C/S1

S23:19pmPO:P207

S42:19amPO:P223

S18:22pmPO:P151

$\mathrm{S} 23: 18 \mathrm{pm} 29: \mathrm{B} / \mathrm{Fo}$

S05:18pmPO:P164

S07:19pmPO:P173

S43:22pmPO:P266

S07:19am04:C/S2

G05:21 am14:C/A1

G05:21 am15:C/A

$\mathrm{S} 23: 18 \mathrm{pm} 29: \mathrm{B} / \mathrm{Fo}$

S16:23am04:C/A2

$\mathrm{S} 35: 21 \mathrm{am} 07: \mathrm{B} / \mathrm{Pi}$

G06:22pmPO:P172

S18:22pmPO:P152

S17:22am10:C/A2

G08:21am10:C/S1

S12:18pm32:C/A2

S11:19pm25:C/A1

S16:23am07:C/A2

G07:18pmPO:P338

S37:21am09:B/Ja

$\mathrm{S} 48: 19 \mathrm{am} 05: \mathrm{B} / \mathrm{Ja}$ 


\section{Goldschmidt 2002 Index}

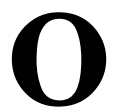

O'Brien PJ

O'Connell R

S20:19am03:A/Co S10:23pm30:C/A1 $\mathrm{S} 35: 21 \mathrm{am} 16: \mathrm{B} / \mathrm{Pi}$

O'Connor S

O'Neill H

O'Neill H

O'Neill H

O'Neill HSC

O'Nions K

O'Nions K

O'Nions K

O'Nions RK

O'Reilly S

O'Reilly S

O'Reilly S

O'Reilly S

O'Reilly SY

O'Reilly SY

O'Reilly SY

O'Reilly SY

O'Reilly SY

O'Sullivan P

O'Sullivan P

G09:18pm25:A/Fm

$\mathrm{G} 10: 21 \mathrm{pm} 26: \mathrm{A} / \mathrm{St}$

S03:22am04:C/S1

S09:22am02:C/A1

S41:22pm21:A/Fm

$\mathrm{S} 41: 22 \mathrm{pm} 25: \mathrm{A} / \mathrm{Fm}$

$\mathrm{S} 41: 23 \mathrm{am} 03: \mathrm{A} / \mathrm{Fm}$

$\mathrm{S} 41: 22 \mathrm{pm} 24: \mathrm{A} / \mathrm{Fm}$

G01:19pmPO:P260

S15:19amPO:P067

G08:21pm21:C/S1

S10:22amPO:P133

S15:18am08:C/A1

$\mathrm{S} 47: 19 \mathrm{am} 07: \mathrm{A} / \mathrm{St}$

S15:19amPO:P059

G05:21am16:C/A1

S10:22amPO:P114

$\mathrm{S} 21: 21 \mathrm{pm} 24: \mathrm{A} / \mathrm{Co}$

$\mathrm{S} 21: 21 \mathrm{pm} 30: \mathrm{A} / \mathrm{Co}$

G08:19pmPO:P158

S24:19pm27:B/Fo

Oba T

Oberholzer P

S28:22pm32:B/Fo

S44:18am10:A/St

S20:19pm30:A/Co

Oberli F

Oberti R

$\mathrm{S} 15: 18 \mathrm{am} 05 \cdot \mathrm{C} / \mathrm{A}$

Obst K

G05:22pmPO:P060

S49:18pmPO:P105

ODP Leg 192 Shipboard Scientists

S10:22amPO:P132

ODP Leg 201 Shipboard Party

S33:18am05:B/Pi

Oelkers E

S34:22am16:B/Ja

Oelkers E

$\mathrm{S} 22: 22 \mathrm{pm} 25: \mathrm{A} / \mathrm{Co}$

Oelkers E

Oelkers E

Oelkers E

Oelkers EH

Ogawa Y

Oger P

Ogorelec B

Ogrinc N

Ogrinc N

$\mathrm{Oh} \mathrm{J}$

Öhlander B

Ohmoto $\mathrm{H}$

Ohmoto $\mathrm{H}$

Ohnishi K

Ohno T

Ohta A

Ohtani E

Ohtani H

Okada H

Okamoto M

Okamura K

Okamura K

Okazaki R

Okazaki R

Olivella S

Olivier L

Olu-Leroy K

Onstott T

Onstott T

Onstott TC

Ootani H

Oppo D

Orel B

Orihashi Y

Orlova M

Orme CA

Orombelli G

Orphan V

Osadchii E

Oschwald P

S22:22amPO:P296

$\mathrm{S} 22 \cdot 22 \mathrm{amPO}: \mathrm{P} 304$

$\mathrm{S} 22: 22 \mathrm{pm} 26: \mathrm{A} / \mathrm{Co}$

G09:19amPO:P122

S36:22am08:B/Pi

S23:19pmPO:P203

S30:18amPO:P251

G04:22pm29:B/Pi

G07:18pmPO:P326

G07:19am09:B/Ja

S07:19pmPO:P171

S07:19pmPO:P173

$\mathrm{S} 23: 18 \mathrm{pm} 29: \mathrm{B} / \mathrm{Fo}$

S41:22amPO:P103

G09:19amPO:P123

G09:18am10:A/Fm

G09:18pm30:A/Fm

S33:18am14:B/Pi

G05:21am12:C/A1

S42:19amPO:P223

G06:22pmPO:P179

$\mathrm{S} 40: 21 \mathrm{am} 07: \mathrm{A} / \mathrm{Fm}$

$\mathrm{S} 40: 21 \mathrm{am} 12: \mathrm{A} / \mathrm{Fm}$

S19:22am03:C/S2

S42:19amPO:P222

S35:21am03:B/Pi

S33:18am11:B/Pi

S33:18am10:B/Pi

$\mathrm{S} 40: 21 \mathrm{pm} 28: \mathrm{A} / \mathrm{Fm}$

G09:19amPO:P124

S28:23am06:B/Fo

G04:22amPO:P241

G01:19pmPO:P286

G05:21am04:C/A1

PLENARY:20am

S28:22pm32:B/Fo

S35:21am06:B/Pi

S18:21pm27:C/S2

G07:18pmPO:P333
$15 \quad \mathrm{~A} 518$

78 A391

39 A145

$7 \quad$ A73

$42 \quad$ A728

6 A578

7 A563

$\begin{array}{ll}\mathbf{4} & \mathbf{A 5 6 3}\end{array}$

6 A880

6 A298

56 A129

23 89

29 A613

42 A75

62 A584

4 A518

6 A292

A155

$36 \quad \mathrm{~A} 176$

$62 \quad$ A38

44 A235

A 278

5 A564

21 A564

A565

5 A303

$20 \quad A 565$

4 A775

58 A566

34 A566

$62 \quad \mathrm{~A} 580$

$4 \quad$ A378

$\begin{array}{ll}49 & \mathbf{A 5 6 7}\end{array}$

54 A275

54 A410

65 A311

$65 \quad \mathrm{~A} 520$

54 A843

26 A568

$\begin{array}{ll}50 & \mathrm{~A} 447\end{array}$

$30 \quad$ A 190

31 A330

$51 \quad \mathbf{A 5 6 8}$

24 A160

$2 \quad \mathbf{A 5 6 9}$

$27 \quad$ A735

$27 \quad$ A857

$\begin{array}{ll}9 & \text { A387 }\end{array}$

$71 \quad$ A569

$26 \quad$ A570

2 A458

$7 \quad$ A707

4 A354

$36 \quad$ A755

$32 \quad$ A559

60 A726

40 A206

40 A544

$48 \quad$ A187

$32 \quad$ A364

39 A543

$4 \quad$ A457

4 A706

4 A458

26 A570

75 A649

$57 \quad \mathrm{~A} 414$

23 A762

$36 \quad$ A617

35 A2

55 A565

39 A571

43 A50

$24 \quad$ A290

Osmaston MF S03:23pmPO:P143 Ostertag-Henning C S23:18pm25:B/Fo Ostertag-Henning C S25:21am04:B/Fo Ostertag-Henning C G04:22pm25:B/Pi $\mathrm{S} 38: 23 \mathrm{amPO}: \mathrm{P} 33$ ald $S$ Otlu N

Otofuji Y

Ott U

Ott U

Ottonello G

Ouyang Z

Ouyang Z

Ouyang Z

Overmann $\mathbf{J}$

Ovtcharova M

Ovtcharova M

Owen R

Owen $\mathrm{T}$

Owen $T$

Owens KE

Ozawa A

Ozawa K

Ozawa K

Ozherelieva N

Ozima M

O’Brien $\mathrm{H}$

Pabalan R

Pabalan R

Pacheco FAL

Pagani M

Pak DK

Pal A

Palenzona $\mathrm{M}$

Pallud C

Palme H

Palme H

Palme H

Palme H

Palmer D

Palmer D

Palmer J

Palmer M

Palmer MR

Palmer MR

Palmer MR

Palmeri R

Palyanova $\mathrm{G}$

Pan Y

Pankratov I

Papainocomou N

Papesch W

Paquette J

Paquette J

Paquette J

Paquin J

Parello F

Parini M

Park E

Parker S

Parker SC

Parkinson I

Parkinson IJ

Parks GA 
Goldschmidt 2002 Index

Author

Code

G06:22pmPO:P173

S11:19am06:C/A1

Petrov

S47:19am 14:A/S

S15:19amPO:P068

Pettke T

Pettke T

$\mathrm{S} 17: 22 \mathrm{pm} 21: \mathrm{C} / \mathrm{A} 2$

S17:22pm29:C/A2

S17:22pm22:C/A2

Pettke T

$\mathrm{S} 17: 22 \mathrm{pm} 25: \mathrm{C} / \mathrm{A} 2$

Pettke T

G06:22pmPO:P170

Pettke T

G06:23pm23:C/S2

Peucker-Ehrenbrink B

S13:18am05:C/A2

Peucker-Ehrenbrink B

S22:23pm30:A/Co

Peytcheva I

G01:19pmPO:P276

Peytcheva I

Peytcheva I

Pezzino A

Pezzino A

Pfänder J

Pfänder $\mathbf{J}$

Pfänder JA

Pfeifer $\mathrm{H}$

Pfeifer $\mathrm{H}$

Pfeifer $\mathrm{H}$

Pfeifer K

Pfister S

Pfretzschner $\mathrm{H}$

Pfretzschner $\mathrm{H}$

01:19pmPO:P289

G05:22pmPO:P052

G01:19pmPO:P288

S44:19amPO:P302

S47:19pmPO:P319

S03:22pm30:C/S 1

S10:23am14:C/A1

G05:21pm27:C/A1

S38:23amPO:P337

S38:23amPO:P340

$\mathrm{S} 23: 18 \mathrm{pm} 24: \mathrm{B} / \mathrm{Fo}$

G07:19pm24:B/J

S28:22amPO:P220

S28:22amPO:P220

S35:19amPO:P247

S22:22amPO:P300

Phelps T

Philippot $\mathrm{P}$

Philippot $\mathrm{P}$

Phillips B

Phillips B

Phillips F

Phillips F

Phillips F

Phipps Morgan J

Phipps Morgan J

Phipps Morgan J

Phipps Morgan J

Phipps Morgan J

Phoenix V

Pi T

Picard S

Picardal F

Pichat $S$

Pichavant M

Pidgeon R

Pidgeon R

Pidgeon RT

Pidgeon RT

Pierce E

13:18am07:C/A2

S18:21am09:C/S2

$\mathrm{S} 48: 18 \mathrm{pm} 29: \mathrm{B} / \mathrm{Ja}$

$\mathrm{S} 37: 21 \mathrm{pm} 29: \mathrm{B} / \mathrm{Ja}$

S31:22am01:A/Co

S28:22pm29:B/Fo

S46:23pm25:A/St

S13:18am12:C/A2

S11:18pm28:C/A1

S13:19amPO:P018

S10:22amPO:P130

S10:23am06:C/A1

S48:19am04:B/Ja

S40:22pmPO:P110

$\mathrm{S} 24: 19 \mathrm{pm} 29: \mathrm{B} / \mathrm{Fo}$

$\mathrm{S} 48: 19 \mathrm{am} 05: \mathrm{B} / \mathrm{Ja}$

S27:23amPO:P228

S16:22pmPO:P023

G01:22pm28:A/St

G01:22pm25:A/St

S45:18pm28:A/Co

S06:19am16:C/S2

S39:23pm30:B/Ja

Pierret M

S22:22amPO:P306

Pierson-Wickmann A

S07:19am04:C/S2
S16:22pmPO:P032

$\mathrm{S} 46: 23 \mathrm{am} 04: \mathrm{A} / \mathrm{St}$

S21:21pm27:A/Co

S40:22pmPO:P108

S40:22pmPO:P111

$\mathrm{S} 46: 23 \mathrm{am} 08: \mathrm{A} / \mathrm{St}$

S29:19pm29:A/St

S44:19amPO:P294

A

Pike AWG
Pillinger C

Pillinger CT

Pilz P

Pimentel MM

Pin $\mathrm{C}$

Pin $\mathrm{C}$

Pina $\mathrm{C}$

Pinchuk G

Pineau $\mathrm{F}$

Pineau $\mathrm{F}$

Pineau $\mathrm{F}$

Pineau $F$

Pinto Ferreira V

Piotrowski A

Piotrowski A

Piotrowski A

Piotrowski A

Pistiner JS

S22:23am11:A/Co
Prog. Abs. Author

\begin{tabular}{rr|}
59 & A \\
14 & A536 \\
$\mathbf{1 6}$ & A596 \\
29 & A671 \\
53 & A37 \\
53 & A75 \\
53 & A304 \\
53 & $\mathrm{~A} 430$ \\
59 & A405 \\
77 & A263
\end{tabular}

Pla Cid J

Plank T

Platt JP

Platt U

Plattner K

Plummer N

Podosek FA

Podosek FA

Poidevin J

Poitrasson $\mathrm{F}$

Pokhilenko N

Pokrovski O

Pokrovsky B

79 A626

Pokrovsky O

3 A573

3 A 811

58 A380 Pokrovsky OS

$23 \quad$ A786

$33 \quad$ A617

33 A744

$52 \quad$ A536

$\begin{array}{ll}73 & \mathbf{A 5 9 7}\end{array}$

41 A519

69 A597

69 A768

9 A634

18 A417

$67 \quad$ A789

$\begin{array}{ll}67 & \text { A789 }\end{array}$

32 A861

65 A453

$3 \mathrm{~A} 113$

37 A489

$11 \quad$ A250

45 A122

$\begin{array}{ll}49 & \mathbf{A 5 9 8}\end{array}$

$\begin{array}{ll}55 & \text { A598 }\end{array}$

81 A599

3 A656

$\begin{array}{ll}8 & \text { A599 }\end{array}$

28 A343

62 A525

73 A600

$17 \quad \mathrm{~A} 68$

71 A600

21 A439

17 A151

67 A601

63 A154

51 A201

51 A609

11 A601

13 A312

$80 \quad \mathbf{A 6 0 2}$

$65 \quad \mathrm{~A} 602$

$13 \quad \mathbf{A 6 0 3}$

$63 \quad$ A723

$76 \quad$ A457

$44 \quad \mathbf{A 6 0 3}$

71 A486

71 A864

76 A267

21 A604

33 A65

36 A45

$7 \quad$ A512

28 A604

$27 \quad$ A713

19 A621

58 A29

6 A618

$50 \quad$ A286

9 A36

9 A121

28 A605

61 A377

58 A605

24 A476

55 A105

67 A104

$75 \quad \mathbf{A 6 0 6}$

74 A606
Poli G

Poller U

Poller U

Poller U

Poller U

Pollok K

Polyak V

Polyakov GV

Pombo SA

Ponomarchuk V

Ponomarchuk V

Ponomarchuk V

Ponomarchuk V

Ponomareva V

Ponthieu M

Ponthieu M

Ponthieu M

Ponthieu M

Popp T

Porcelli D

Porcelli D

Porcelli D

Porcelli D

Porcelli D

Porcelli D

Porcelli D

Porcelli D

Poreda R

Potter KN

Potts R

Poulson R

Powell W

Powlesland D

Pravdivtseva OV S40:21 am05:A/Fm

Pravdivtseva OV G01:22pm24:A/St

Prave AR S07:19pmPO:P167

Predota M

Prieto $\mathbf{M}$

Prieto M

Prieur D

Prikhod'ko V

Prikhodko V

Prins MA

Prinzhofer A

Probst A

Probst A

Probst J

Prokofiev V

Prokopchuk S

Prostyakov K

Prostyakov K

Prostyakov K

Ptacek CJ

Puceat E

Puchtel IS

Puchtel IS

Punturo R

Purtschert R

Purtschert R

Purtschert R

Purtschert R

Pushkarev Y

Putlitz B

Putnis A

G05:21am15:C/A1

S13:18am02:C/A2

S32:18pm23:B/Pi

$\mathrm{S} 28: 23 \mathrm{pm} 23: \mathrm{B} / \mathrm{Fo}$

S01:19amPO:P144 
Goldschmidt 2002 Index

Author

Regenspurg S

Regnier P

Regnier $\mathrm{P}$

Regnier P

Rehfeldt T

Rehkämper M

Rehkämper M

Rehkämper M

Rehkämper M

Rehkämper M

Rehkämper M

Rehkämper M

Reichard PU

Reichard PU

Reichert $\mathrm{P}$

Reichert P

Reid J

Reid J

Reid M

Reid M

Reid M

Reid MR

Reid RP

Reiners P

Reinhard M

Reinhardt M

Reinhardt M

Reisberg L

Reisberg L

Reisberg L

Reisberg L

Reisberg L

Reischmann $\mathrm{T}$

Reischmann $\mathrm{T}$

Reischmann T

Reitz A

Renac C

Renaud S

Renna MR

Renne P

Renne $\mathrm{P}$

Renne P

Rentsch D

Resnik A

Reuter R

Reuter $\mathrm{S}$

Reuter S

Reutsky V

Reutsky V

Revel-Rolland M

Reville K

Reyes AG

Reyf F

Reynard B

Reynaud-Vaganay S

Reynolds B

Reynolds B

Ribe N

Richard L

Richard L

Richardson SH

Richnow HH

Richter C

richter W

Riciputi L

Riciputi L

Riciputi LR

Rickaby $\mathbf{R}$

Rickard D

Rickers K

Ridgwell A

Ridley M

Rigato $\mathrm{V}$

Righi D

Righter K

Righter K

Righter K

Rilling J

Rinkevich B

Rinterknecht V

Rios DC

Riotte J

Ripley EM
Code

S30:19am12:B/Pi S19:22pm26:C/S2 $\mathrm{S} 19: 22 \mathrm{pm} 21: \mathrm{C} / \mathrm{S} 2$ S19:23amPO:P160 G05:22pmPO:P060 $\mathrm{S} 44: 18 \mathrm{am} 13: \mathrm{A} / \mathrm{S}$ S02:18pm31:C/S1 $\mathrm{S} 02 \cdot 19 \mathrm{pm} 26 \cdot \mathrm{C} / \mathrm{S} 1$ $\mathrm{S} 03: 22 \mathrm{am} 10: \mathrm{C} / \mathrm{S}$ S03:22pm26:C/S1 S41:22pm30:A/Fm S22:23pm21:A/Co S36:22am06:B/Pi S36:23amPO:P262 S30:19am09:B/Pi

S30:19am10:B/Pi

S47:19pmPO:P316 S03:22pm24:C/S1 G05:21pm29:C/A1 S16:23am10:C/A2 S16:23pm25:C/A2 S16:23pm27:C/A2 S49:19am05:A/Fm S45:18pm27:A/Co S38:22pm 23:B/Ja S30:18amPO:P254 G04:22amPO:P231 S02:18pm29:C/S1 S11:18pm30:C/A1 S11:18amPO:P045 S11:18amPO:P050 G05:22pmPO:P072 G01:19pmPO:P257 G01:19pmPO:P266 G01:22am08:A/St S23:18pm24:B/Fo S15:18am08:C/A1 $\mathrm{S} 24: 19 \mathrm{pm} 32: \mathrm{B} / \mathrm{Fo}$ S16:22pmPO:P031 S02:19pm 27:C/S1 S11:18amPO:P048 S10:22amPO:P131

S48:18pm30:B/Ja G09:19amPO:P120 G04:22pm28:B/Pi

S23:19pmPO:P202 S42:19amPO:P221 G09:19amPO:P127 G09:19amPO:P134 $\mathrm{S} 27: 22 \mathrm{am} 14: \mathrm{B} / \mathrm{Fo}$ $\mathrm{S} 48: 19 \mathrm{am} 01: \mathrm{B} / \mathrm{Ja}$ G06:23pm26:C/S2 S17:23amPO:P010 S18:21am09:C/S2 S49:18pmPO:P106 S21:21am07:A/Co S22:23pm28:A/Co S10:23pm22:C/A1 $\mathrm{S} 34: 22 \mathrm{am} 01: \mathrm{B} / \mathrm{Ja}$ S34:22am04:B/Ja S10:22amPO:P138 $\mathrm{S} 38: 22 \mathrm{pm} 25: \mathrm{B} / \mathrm{J}$ S26:23amPO:P204 G08:21am13:C/S 1 S44:18pm21:A/St S18:21 am14:C/S2 S47:19pmPO:P312 S49:19am14:A/Fm S48:19am06:B/Ja S18:21am13:C/S2 S27:22am03:B/Fo S37:23amPO:P331 S37:23amPO:P325 G08:21pm31:C/S S02:19am13:C/S S14:19pm26:C/A2 S03:22pm24:C/S1 S14:19am04:C/A2 S49:19am07:A/Fm S28:22amPO:P219 G01:22pm27:A/St S22:23am08:A/Co S15:18am03:C/A1

Prog. Abs.

Author

Code

Prog. Abs.

Author

Code

Prog. Abs.

$16 \quad$ A587

$\begin{array}{ll}53 & \mathbf{A 6 2 8}\end{array}$

53 A795

64 A373

58 A566

5 A847

$\begin{array}{ll}7 & \text { A227 }\end{array}$

18 A844

$46 \quad$ A686

52 A304

$56 \quad$ A629

$\begin{array}{ll}79 & \mathbf{A 5 5 4}\end{array}$

50 A629

68 A244

16 A186

$16 \mathbf{A 6 3 0}$

$33 \quad$ A630

52 A654

$41 \quad \mathbf{7 1 8}$

74 A284

79 A631

79 A802

17 A808

11 A631

$56 \mathbf{A 6 3 2}$

$31 \quad$ A632

$57 \quad$ A70

$7 \quad$ A169

$8 \quad \mathbf{A 6 3 3}$

$27 \quad$ A96

27 A625

59 A876

23 A19

$23 \quad$ A330

$46 \quad \mathbf{6 3 3}$

$9 \mathbf{A 6 3 4}$

4 A518

$21 \quad \mathrm{~A} 680$

$63 \quad$ A634

18 A487

27 A407

$62 \quad$ A559

1 A48

26 A514

51 A107

A 141

32 A233

26 A635

26 A871

48 A175

17 A229

$\mathbf{A 6 3 5}$
$\mathbf{6}$

63 A636

$37 \quad \mathrm{~A} 489$

$34 \quad \mathrm{~A} 636$

$\begin{array}{ll}38 & \mathbf{A 6 3 7}\end{array}$

$\begin{array}{ll}79 & \mathbf{4} 705\end{array}$

78 A375

49 A318

$\begin{array}{ll}49 & \mathbf{6 6 3 7}\end{array}$

62 A870

56 A504

66 A432

36 A561

$10 \quad \mathbf{6 6 3 8}$

37 A427

33 A226

$17 \mathbf{A 6 3 8}$

17 A843

37 A68

$48 \quad \mathbf{A 6 3 9}$

69 A472

69 A15

42 A232

$12 \quad$ A639

$\begin{array}{ll}20 & \mathrm{~A} 137\end{array}$

52 A654

4 A389

17 A216

67 A640

$51 \quad \mathbf{A 6 4 0}$

74 A641

$4 \quad \mathrm{~A} 452$

S22:23am09:A/Co $\mathrm{S} 49: 19 \mathrm{pm} 25: \mathrm{A} / \mathrm{Fm}$ S11:18pm29:C/A1 G10:22pmPO:P278 S10:22amPO:P124 S01:18am13:C/S

$\mathrm{S} 45: 18 \mathrm{am} 14: \mathrm{A} / \mathrm{Co}$ S02:19am02:C/S1 S43:21am08:A/St S26:23amPO:P204 S11:18amPO:P047 $\mathrm{S} 17: 22 \mathrm{pm} 30: \mathrm{C} / \mathrm{A} 2$ $\mathrm{S} 23: 18 \mathrm{pm} 23: \mathrm{B} / \mathrm{Fo}$ S42:18am12:B/Fo S22:23am10:A/Co S22:22pm28:A/Co G01:19pmPO:P264 S27:23amPO:P225 S33:19amPO:P243 $\mathrm{S} 30: 19 \mathrm{pm} 30: \mathrm{B} / \mathrm{Pi}$

Rock GJ

Rodriguez IR

Rodriguez-Tovar FJ S04.23amPO:P147

Roehm C G04:23pm22:B/Pi

Roger M S11:18amPO:P044

Rogers $\mathrm{N}$

Rogers N

Rogers NW

Roh Y

Rohling EJ 
Sanloup C

Sano $Y$

Sano Y

Santella N

Santos A

Santos A

Santos A

Sapienza G

Sarangi S

Sarda $\mathbf{P}$

Sarkar SC

Sarnthein M

Sartbaeva A

Sass H

Sassen R

Satir M

Satir M

Satir M

Sato $\mathrm{H}$

Sato $\mathrm{H}$

Sato K

Sato T

Sato $T$

Satoh $\mathrm{H}$

Saunders A

Saunders A

Saunders AD

Savatenkov V

Savenko A

Savenko A

Savina M

Savina M

Savov I

Savoye S

Saylor B

Saylor B

Sbisa' A

Scaillet B

Scambelluri M

Scarrow JH

Schaefer B

Schaefer B

Schaefer BF

Schaefer JM

Schaefer JM

Schaller M

Schaltegger U

Schaltegger U

Schaltegger U

Schardt C

Scharer U

Schatz H

Schatz OJ

Schauble E

Schauffler S

Scheffler K

Schefuss E

Scheidegger A

Scheidegger AM

Scheidegger AM

Scheinost A

Scheinost A

Scheinost AC

Scheinost AC

Schenk K

Schenk K

Scher HD

Scherer E

Scherer EE

Schexnayder JM

Schiano P

Schiano P

Schick L

Schiff S

Schilla A

Schilling J

Schilling J

Schilling J

Schilman B

Schimmelmann A

Schindler EU

Schindler M

Schindler M
G09:18pm24:A/Fm

S14:18pmPO:P007

S49:18pmPO:P107

S31:22am08:A/Co

S48:19pmPO:P355

S48:19pmPO:P357

G10:22pmPO:P280

S12:19pmPO:P040

G01:22pm29:A/St

S40:22am07:A/Fm

S45:18am09:A/Co

S24:19pm21:B/Fo

G09:18pm28:A/Fm

S33:18am07:B/P

$\mathrm{S} 35: 21 \mathrm{am} 05: \mathrm{B} / \mathrm{P}$

G05:21am13:C/A1

G01:22am07:A/St

G05:22pmPO:P064

G09:18pm30:A/Fm

G09:19amPO:P122

G01:19pmPO:P282

S37:23amPO:P328

G06:23pm27:C/S2

S47:19am10:A/St

S10:22amPO:P115

S10:22amPO:P128

S08:22pmPO:P019

S45:19amPO:P032

G09:18am14:A/Fm

S49:18pmPO:P102

S01:18am06:C/S1

S47:19am 11:A/St

S13:19amPO:P019

S31:23amPO:P283

S48:19pmPO:P366

S39:22pmPO:P356

G01:22am09:A/St

S16:22pmPO:P023

S15:19amPO:P068

S10:22amPO:P134

S21:21am06:A/Co

S10:22amPO:P132

S10:22amPO:P134

$\mathrm{S} 28: 22 \mathrm{pm} 32: \mathrm{B} / \mathrm{Fo}$

S28:22pm30:B/Fo

S21:21am14:A/Co

S11:19am06:C/A1

G05:21pm27:C/A1

S10:22pm28:C/A1

S17:23amPO:P011

S45:18am03:A/Co

S02:18pm29:C/S

S17:22am08:C/A2

S41:23pm26:A/Fm

S43:21am03:A/St

G03:21pm21:B/Fo

$\mathrm{S} 35: 21 \mathrm{am} 01: \mathrm{B} / \mathrm{Pi}$

$\mathrm{S} 39: 23 \mathrm{pm} 25: \mathrm{B} / \mathrm{Ja}$

S48:18pm22:B/Ja

$\mathrm{S} 37: 21 \mathrm{pm} 28: \mathrm{B} / \mathrm{Ja}$

S48:18pm23:B/Ja

G07:19pm24:B/Ja

S48:18pm24:B/Ja

S48:19pmPO:P365

$\mathrm{S} 39: 23 \mathrm{pm} 21: \mathrm{B} / \mathrm{Ja}$

$\mathrm{S} 39: 23 \mathrm{pm} 22: \mathrm{B} / \mathrm{Ja}$

S42:19amPO:P224

S45:18am13:A/Co

S03:22am09:C/S1

$\mathrm{S} 39: 23 \mathrm{am} 12: \mathrm{B} / \mathrm{Ja}$

S14:19pm25:C/A2

S10:23pm27:C/A1

G04:23pm24:B/P

$\mathrm{S} 38: 22 \mathrm{pm} 28: \mathrm{B} / \mathrm{J}$

S28:23am09:B/Fo

S10:22amPO:P112

S10:22amPO:P113

S10:22amPO:P129

G03:21pm23:B/Fo

S43:21am04:A/St

S30:19am03:B/Pi

S48:18am11:B/Ja

S48:19pmPO:P363
A666

A556

34 A666

A667

A230

34 A262

A803

8 A667

51 A286

\begin{tabular}{ll}
$\mathbf{A 6 6 8}$ \\
\hline
\end{tabular}

6 A308

14437

A627

A161

9 $\mathrm{A} 872$

36 A700

$46 \quad$ A134

A714

A707

26 A568

A668

69 A249

77 A669

$16 \quad$ A527

62 A5

62 A392

61 A773

33 A669

A670

4 A285

2 A171

$6 \quad$ A588

$28 \mathrm{~A} 670$

67 A180

34 A87

70 A671

46 A590

63 A154

29 A671

62 A672

38 A806

$62 \quad$ A580

62 A672

55 A565

55 A672

$38 \quad \mathbf{4 6 7 3}$

14 A536

41 A519

$52 \quad$ A673

63 A674

A699

A169

$47 \quad$ A674

81 A675

$40 \quad$ A622

41 A675

39 A687

$80 \quad$ A90

11 A676

45 A163

11 A799

8 A417

11 A676

34 A850

80 A206

80 A592

$32 \quad$ A677

$\begin{array}{ll}6 & \mathbf{4 6 7 7}\end{array}$

$46 \quad$ A510

75 A192

$20 \mathbf{A 6 7 8}$

78 A260

77 A497

56 A25

$75 \quad$ A832

62 A9

62 A22

62 A478

$41 \quad$ A14

$40 \quad$ A697

16 A 325

6 A540

$34 \quad$ A678

Author

Schippers A

Schlegel ML

Schloemer S

Schlosser P

Schlosser P

Schlosser P

Schlosser P

Schlosser P

Schlosser P

Schluechter C

Schluechter C

Schlunegger $F$

Schmickler B

Schmidt C

Schmidt DN

Schmidt M

Schmidt TC

Schmitt A

Schmitt A

Schmitz MD

Schneebeli M

Schneider C

Schneider D

Schneider J

Schoell M

Schoenberg R

Schoenberg R

Schoenberg R

Schöler H

Schöler H

Scholten J

Scholten J

Schönbächler M

chönbächler M

Schott J

Schott J

Schott J

Schott J 


\section{Goldschmidt 2002 Index}

Author

Code

$\mathrm{S} 41: 23 \mathrm{pm} 28: \mathrm{A} / \mathrm{Fm}$ $\mathrm{S} 22: 23 \mathrm{pm} 28: \mathrm{A} / \mathrm{Co}$

Sherlock S

Sherman DM S18:21pm21:C/S2

Sherman DM

:21pm26:B/J

Sherwood Lollar B $\quad$ S33:18am11:B/Pi

Sherwood Lollar B S33:18am10:B/Pi

Sherwood OA S49:19pm25:A/Fm

Shibata S S44:18pm28:A/St

Shibata S

Shibata Y

Shikazono N

Shikazono N

Shikazono N

Shikazono N

Shikazono N

Shikazono N

Shilobreeva S

Shilobreeva S

Shim S

Shimaoka A

Shimizu A

Shimizu H

Shimizu $\mathrm{H}$

Shimizu K

Shimizu N

Shimizu N

Shimizu N

Shimizu N

Shimizu N

Shimizu N

Shimoda G

Shimoda G

Shimoyama A

Shimoyama A

Shimoyama A

Shirey S

Shirey $S$

Shirey SB

Short J

Shosa J

Shotyk W

Shukla A

Shukla P

Shuster D

Shuster D

Shuster D

Sial A

Sial A

Sial AN

Siame L

Siddoway C

Siebel W

Siebel W

Siebel W

Siebert C

Siebert C

Siebert J

Siegle S

Siena F

Siena $\mathrm{F}$

Siena F

Sierro F

Sigfusson B

Sigg L

Sigg L

Sigleo AC

Sigurdsson I

Silk P

Sillitoe R

Simionovici A

Simionovici A

Simmons S

Simon J

Simon JI

Simon L

Simon NSC

Simonetti A

Simonin J

Simons D

Simons D

Simpson AJ

Simpson HJ

Sims K
Prog. Abs. Author

\section{$81 \quad$ A484}

$79 \quad$ A705

$43 \quad$ A705

45 A583

4 A457

4 A706

22 A706

$10 \quad$ A763

$\begin{array}{ll}65 & \text { A707 }\end{array}$

57 A791

$\begin{array}{ll}7 & \mathbf{A 7 0 7}\end{array}$

24 A385

$25 \quad \mathrm{~A} 352$

$25 \quad$ A787

26 A568

$26 \quad$ A570

28 A605

$\begin{array}{ll}42 & \text { A708 }\end{array}$

$\begin{array}{ll}73 & \mathbf{A 7 0 8}\end{array}$

$\begin{array}{ll}76 & \text { A709 }\end{array}$

$\begin{array}{ll}9 & \text { A710 }\end{array}$

$36 \quad$ A755

65 A315

$37 \quad \mathbf{A 7 0 9}$

$4 \quad$ A626

8 A710

9 A316

22 A148

27 A822

78 A725

$36 \quad$ A755

62 A711

25 A564

27 A546

57 A855

28 A437

43 A 365

37 A711

44 A390

$\begin{array}{ll}42 & \mathrm{~A} 712\end{array}$

18 A275

61 A712

61 A712

45 A224

$71 \quad \mathrm{~A} 713$

73 A827

24 A475

58 A605

27 A713

71 A714

$55 \quad$ A745

36 A700

$46 \quad \mathbf{A 1 3 4}$

$58 \quad \mathrm{~A} 714$

56 A503

$\begin{array}{ll}56 & \text { A715 }\end{array}$

$\begin{array}{ll}47 & \text { A715 }\end{array}$

30 A141

4 A90

$4 \quad$ A149

$29 \quad$ A59

54 A115

54 A275

22 A852

44378

$51 \quad \mathbf{A 7 1 6}$

8 A739

$10 \quad$ A716

$\begin{array}{ll}6 & \text { A738 }\end{array}$

37 A489

50 A447

53 A86

A718

79 A130

52 A717

$62 \quad$ A717

37 A741

$37 \quad$ A198

$\begin{array}{ll}39 & \mathbf{A 7 1 8}\end{array}$

49 A393

30 A23

$49 \quad$ A749

$\begin{array}{ll}10 & \text { A47 }\end{array}$

Sims K

Sims K

Sindern $S$

Singh S

Sivan $O$

Sket B

Slater G

Smith A

Smith A

Smith A

Smith F

Snape C

Snow J

Soest R

Solé J

Soler J

Song $\mathrm{H}$

Song $\mathrm{S}$

Song Y

Sparks S

\section{Sims K}

Sinclair $\mathrm{H}$

Singh SK

Sinninghe Damste JS S35:21am01:B/Pi

Sisson T

Sisterson J

Sitnikova M

Skirrow R

Skouri F

Skublov S

Slaughter M

Sleep NH

Slejko F

Slomp CP

Slowey N

Sluzhenikin S

Smirnov S

Smirnov S

Smith D

Smith K

Smith T

Snorasson A

Snow JE

Snow JE

Snow JE

Snow TP

Snyder DC

Snytnikov V

Snytnikov V

Sobolev A

Sobolev A

Sobolev A

Sobolev A

Sobolev N

Sobolev N

Sobolev R

Sobotovich E

Söderlund U

Sohn Y

Sohrin Y

Sohrin Y

Solomon K

Solomon SC

Sommacal S

Sophie $S$

Sorensen S

Sorensen SS

Sorokin A

Sotnikov V

Sotnikov V

Southon JR

Souvent $P$

Sowerby $S$

Spalla O

Spangenberg J

Spangenberg JE

Spangenberg JE

Spangenberg JE

Spanic D

Sparks D

Sparks S

S11:19am01:C/A1

S11:19am05:C/A1

S16:23am10:C/A2

S21:22pmPO:P288

S12:19pmPO:P043

S22:23am02:A/Co

S21:21pm21:A/Co

S40:21pm29:A/Fm

S12:19pmPO:P043

S31:22am09:A/Co

G04:22amPO:P241

S17:23amPO:P001

$\mathrm{S} 35: 21 \mathrm{am} 10: \mathrm{B} / \mathrm{Pi}$

G06:22pmPO:P178

$\mathrm{S} 33: 18 \mathrm{am} 10: \mathrm{B} / \mathrm{Pi}$

G07:19am10:B/Ja

S09:22am07:C/A1

G05:22pmPO:P047

S30:18amPO:P249

S42:19amPO:P220

S17:23amPO:P007

S17:23amPO:P006

G06:23pm29:C/S2

$\mathrm{S} 30: 19 \mathrm{am} 05: \mathrm{B} / \mathrm{Pi}$

$\mathrm{S} 19: 22 \mathrm{pm} 27: \mathrm{C} / \mathrm{S} 2$

S22:23am10:A/Co

S33:18am03:B/Pi

S25:22amPO:P213

$\mathrm{S} 39: 23 \mathrm{am} 05: \mathrm{B} / \mathrm{Ja}$

S14:19pm27:C/A2

S05:19pm26:C/S2 
Goldschmidt 2002 Index

Author

Code

S02:18pm32:C/S1

S17:22am08:C/A2

$\mathrm{S} 24: 19 \mathrm{am} 07: \mathrm{B} / \mathrm{Fo}$

$\mathrm{S} 28: 23 \mathrm{pm} 23: \mathrm{B} / \mathrm{Fo}$

S40:21pm30:A/Fm

S23:19pmPO:P209

S42:19amPO:P221

S44:19amPO:P298

S47:19pmPO:P319

S44:19amPO:P306

S09:22am06:C/A1

S49:19am13:A/Fm

S36:21 pm25:B/Pi

S08:22pmPO:P015

S28:22pm31:B/Fo

$\mathrm{S} 46: 23 \mathrm{am} 06: \mathrm{A} / \mathrm{St}$

S46:23am01:A/S

S08:21am07:C/A2

S26:23amPO:P204

$\mathrm{S} 21: 21 \mathrm{am} 01: \mathrm{A} / \mathrm{Co}$

$\mathrm{S} 20: 19 \mathrm{am} 04: \mathrm{A} / \mathrm{Co}$

S25:22amPO:P211

S20:19am07:A/Co

$\mathrm{S} 11: 18 \mathrm{pm} 21: \mathrm{C} / \mathrm{A} 1$

G05:21am10:C/A1

$\mathrm{S} 36: 22 \mathrm{am} 12: \mathrm{B} / \mathrm{Pi}$

G04:22pm24:B/Pi

G04:22pm23:B/P

G04:22amPO:P239

G04:22amPO:P244

G04:22amPO:P253

S10:23am 11:C/A1

S23:19pmPO:P202

S21:22pmPO:P286

G09:19amPO:P121

S21:21 pm29:A/Co

S46:23am09:A/St

$\mathrm{S} 21: 21 \mathrm{pm} 28: \mathrm{A} / \mathrm{Co}$

G04:22amPO:P249

G09:18pm26:A/Fm

$\mathrm{S} 32: 18 \mathrm{pm} 29: \mathrm{B} / \mathrm{Pi}$

S48:18am15:B/Ja

S31:22pm22:A/Co

G09:19amPO:P121

$\mathrm{S} 23: 18 \mathrm{pm} 28: \mathrm{B} / \mathrm{Fo}$

$\mathrm{S} 40: 21 \mathrm{pm} 28: \mathrm{A} / \mathrm{Fm}$

S31:22am08:A/Co

$\mathrm{S} 31: 22 \mathrm{am} 04: \mathrm{A} / \mathrm{Co}$

S31:22am06: $\mathrm{A} / \mathrm{Co}$

S19:22am10:C/S2

S11:18amPO:P054

S10:22pm22:C/A1

S19:23amPO:P159

G04:22pm 25:B/Pi

S28:22pm31:B/Fo

$\mathrm{S} 34: 22 \mathrm{am} 12: \mathrm{B} / \mathrm{Ja}$

S34:23amPO:P318

$\mathrm{S} 34: 22 \mathrm{am} 12: \mathrm{B} / \mathrm{Ja}$

S30:19pm24:B/P

S23:18pm30:B/Fo

S18:21am12:C/S2

$\mathrm{S} 31: 22 \mathrm{pm} 22: \mathrm{A} / \mathrm{Co}$

S36:21 pm29:B/Pi

S36:23amPO:P259

S12:18pm23:C/A2

G05:21pm25:C/A1

S40:22am10:A/Fm

S43:21am04:A/St

S35:21am09:B/Pi

G09:19amPO:P129

G09:19amPO:P131

S10:22amPO:P139

S14:19am06:C/A2

S34:22am08:B/Ja

S40:21pm22:A/Fm

S39:22pmPO:P353

S31:22am03:A/Co

G09:18am09:A/Fm

S11:18amPO:P055

S10:22amPO:P117

S17:22am 11:C/A2

S46:23pm31:A/St

$\mathrm{S} 16: 23 \mathrm{pm} 30 \cdot \mathrm{C} / \mathrm{A} 2$
Prog. Abs. Author

\begin{tabular}{ll}
7 & $\mathbf{A 7 4 3}$ \\
\hline &
\end{tabular}

Sutton S

A674 Sutton S

15 A482 Sutton S

80 A174 Suzuki A

45 A743 Suzuki A

30 A685 Suzuki K

2 A233

33 A246

33 A744

33 A836

A368

$\begin{array}{ll}17 & \text { A744 }\end{array}$

44 A

$61 \quad$ A70

5 A745

76 A234

\begin{tabular}{ll} 
A6746 \\
\hline
\end{tabular}

A745

$66 \quad \mathrm{~A} 432$

38 A831

$15 \quad \mathrm{~A} 730$

66 A171

$15 \quad \mathbf{A 7 4 6}$

8 A501

$36 \quad \mathbf{A 7 4 7}$

50 A541

51 A595

51 A830

57 A283

57 A534

$57 \quad$ A747

73 A473

$30 \quad$ A141

65 A221

26 A516

$44 \mathbf{A 5 9 3}$

$\begin{array}{ll}76 & \text { A748 }\end{array}$

44 A51

57 A688

A136

$10 \quad \mathrm{~A} 627$

$6 \quad$ A679

55 A748

26 A516

9 A237

45 A458

49 A667

49 A679

49 A749

48 A660

7749

52 A284

64 A372

51 A750

55 A745

49 A513

68 A750

49 A513

22 A700

9 A751

$37 \quad \mathbf{A 7 5 1}$

55 A748

$44 \quad \mathbf{A 3 7 8}$

68 A109

$9 \quad$ A710

41 A560

50 A752

$\begin{array}{ll}40 & \mathbf{6 9 9 7}\end{array}$

$39 \mathbf{A 7 5 2}$

26 A136

26 A821

62 A878

$14 \quad \mathbf{A 5}$

$\begin{array}{ll}49 & \mathbf{A 7 5 3}\end{array}$

$45 \quad \mathbf{A 7 5 3}$

$70 \quad$ A519

49 A334

2 A263

$27 \quad$ A754

62 A66

47 A 08

81 A755

79 A81

Suzuki K

Suzuki Y

Sval'nov V

Svojtka M

Swart PK

Swarzenski P

Swindle T

Sydler P

Sylvain L

Sylvester P

Synal HA

Szabo C

Szaran J

Székely B

Szocs T

Szramek K

Tachibana S

Tackley PJ

Tadanier CJ

Tagami $\mathrm{T}$

Tagami $\mathrm{T}$

Tagami $\mathrm{T}$

Tagami T

Tagirov B

Tagirov B

Tagirov B

Taguchi T

Taillefert M

Taillefert M

Takahashi E

Takahashi T

Takai K

Takebe M

Takemura K

Takigami Y

Takigami Y

Takino A

Talent JA

Tamburini F

Tan B

Tanaka K

Tanaka S

Tanaka S

Tanaka T

Tanaka T

Tanaka T

Tang S

Tang S

Tanimizu M

Tao M

Tarakanov S

Tarawneh K

Tarney J

Tatsumi Y

Tatsumi Y

Tatsumi Y

Tatsumi Y

Taubald H

Taunton A

Taylor G

Taylor H

Taylor R

Taylor $\mathbf{R}$
Taylor R

Sverjensky D

Tavares Ferreira PL

Code

Prog. Abs.

Author

S48:18pm24:B/Ja

S49:19am06:A/Fm

S17:22pm23:C/A2

G07:18pmPO:P344

G04:22amPO:P234

G05:21am12:C/A1

S22:22amPO:P297

S10:23pm25:C/A1

S49:18pmPO:P101

S23:19pmPO:P204

S37:21pm23:B/Ja

S47:19am15:A/St

S24:18pmPO:P215

$\mathrm{S} 22: 23 \mathrm{pm} 21: \mathrm{A} / \mathrm{Co}$

S46:23pm30:A/St

G07:18pmPO:P333

S41:23am08:A/Fm

S22:23am14:A/Co

$\mathrm{S} 46: 23 \mathrm{pm} 31: \mathrm{A} / \mathrm{St}$

S17:22pm23:C/A2

S38:23amPO:P341

G10:22pmPO:P275

G10:22pmPO:P279

$\mathrm{G} 04: 22 \mathrm{pm} 30: \mathrm{B} / \mathrm{Pi}$

12 A401

S10:22pm30:C/A1

S48:18pm32:B/Ja

G01:19pmPO:P275

G01:19pmPO:P277

G01:19pmPO:P290

G01:22am01:A/St

S18:21pm27:C/S2

S18:21pm29:C/S2

S18:22pmPO:P150

S49:19am10:A/Fm

$\mathrm{S} 30: 19 \mathrm{pm} 29: \mathrm{B} / \mathrm{P}$

S19:22pm25:C/S2

G05:22pmPO:P053

$\mathrm{S} 07: 19 \mathrm{am} 02: \mathrm{C} / \mathrm{S} 2$

S33:18am08:B/Pi

S42:19amPO:P225

G01:22am01:A/St

G01:19pmPO:P268

G01:19pmPO:P286

G09:18pm30:A/Fm

S23:19pmPO:P201

G04:22pm22:B/P

S11:19pm24:C/A1

S07:19am02:C/S2

S36:23amPO:P265

S39:22pmPO:P362

S44:18pm28:A/St 
Goldschmidt 2002 Index

\begin{tabular}{|c|c|c|c|c|c|c|c|c|c|c|c|}
\hline Author & Code & Prog. & Abs. & Author & Code & Prog. & Abs. & Author & Code & Prog. & Abs. \\
\hline Tonarini S & S14:19am07:C/A2 & 14 & A445 & Ushikubo T & G08:21am06:C/S1 & 36 & A792 & Vannucci R & $\mathrm{S} 47: 19 \mathrm{am} 06: \mathrm{A} / \mathrm{St}$ & 16 & A775 \\
\hline Tonarini $\mathbf{S}$ & S14:19pm28:C/A2 & 20 & $\mathbf{A 7 8 0}$ & Utsunomiya S & S07:18pm32:C/S2 & 8 & A537 & Vannucci R & S11:19pm31:C/A1 & 19 & A 621 \\
\hline Tonarini S & G05:22pmPO:P047 & 58 & A231 & Uysal IT & $\mathrm{S} 04: 23 \mathrm{pm} 28: \mathrm{C} / \mathrm{S} 1$ & 78 & A283 & Vannucci R & S13:19amPO:P016 & 28 & A238 \\
\hline Tonarini S & G06:23am10:C/S2 & 72 & A186 & & & & & Vannucci R & S15:19amPO:P068 & 29 & A671 \\
\hline Tonolla M & S30:18amPO:P255 & 31 & A663 & & & & & Vannucci R & G05:22pmPO:P058 & 58 & A 465 \\
\hline Toomey DR & S11:19pm23:C/A1 & 19 & $\mathbf{A 7 8 0}$ & & & & & Vannucci R & S16:22pmPO:P031 & 63 & A634 \\
\hline Tooth AF & $\mathrm{S} 19: 22 \mathrm{am} 04: \mathrm{C} / \mathrm{S} 2$ & 48 & A222 & & & & & Vantelon D & S48:18pm23:B/Ja & 11 & A799 \\
\hline Toplis M & S40:22pmPO:P108 & 71 & A486 & & & & & Varekamp J & S24:18pmPO:P216 & 31 & A772 \\
\hline Toporski J & G04:23am01:B/Pi & 72 & A781 & & & & & Varekamp JC & S17:22pm24:C/A2 & 53 & $\mathbf{A 8 0 0}$ \\
\hline Toppani A & G08:21am07:C/S1 & 36 & A781 & & & & & Varela ME & G08:21am05:C/S1 & 36 & A362 \\
\hline Torgersen $\mathrm{T}$ & $\mathrm{S} 40: 21 \mathrm{pm} 28: \mathrm{A} / \mathrm{Fm}$ & 45 & A458 & & & & & Varfalvy L & $\mathrm{S} 30: 19 \mathrm{am} 04: \mathrm{B} / \mathrm{Pi}$ & 16 & A319 \\
\hline Torn M & S25:22amPO:P211 & 66 & A171 & & & & & Varol E & G05:22pmPO:P067 & 58 & A800 \\
\hline Torsander $\mathrm{P}$ & $\mathrm{S} 22: 22 \mathrm{pm} 25: \mathrm{A} / \mathrm{Co}$ & 54 & A275 & & & & & Varrica D & G07:18pmPO:P328 & 24 & A193 \\
\hline Tossell JA & S18:21pm24:C/S2 & 43 & A782 & & & & & Vasconcelos C & S49:19am05:A/Fm & 17 & A808 \\
\hline Tossell JA & S37:21pm30:B/Ja & 45 & A782 & Vaccaro C & S14:18pmPO:P002 & 29 & A59 & Vasconcelos C & S33:19amPO:P242 & 32 & A506 \\
\hline Touchard Y & S27:23amPO:P225 & 67 & A306 & Vadlamani Ravikant & S20:18pmPO:P028 & 30 & A793 & Vasconcelos C & S49:18pmPO:P108 & 34 & A801 \\
\hline Tournassat C & G07:19am14:B/Ja & 12 & A783 & Valenta A & S01:18am09:C/S1 & 2 & A583 & Vasconcelos C & $\mathrm{S} 35: 21 \mathrm{am} 11: \mathrm{B} / \mathrm{Pi}$ & 39 & A494 \\
\hline Townley H & S20:19pm22:A/Co & 20 & A365 & Valentino GM & G07:18pmPO:P345 & 25 & A793 & Vasconcelos C & G04:23pm26:B/Pi & 77 & A522 \\
\hline Traber D & S19:22am01:C/S2 & 48 & A473 & Valentino GM & G04:22amPO:P235 & 57 & A126 & Vasconcelos PM & S46:22pmPO:P270 & 71 & A713 \\
\hline Trainor $\mathrm{T}$ & G07:19pm23:B/Ja & 18 & A374 & Vali H & S49:19am03:A/Fm & 17 & A579 & Vasudevan D & S48:19pmPO:P364 & 34 & A801 \\
\hline Travin A & S20:19pm28:A/Co & 20 & A791 & Vali H & G09:19amPO:P111 & 25 & A138 & Vautravers M & G03:19pmPO:P238 & 24 & A802 \\
\hline Travin A & S20:18pmPO:P027 & 30 & A615 & Vali H & S03:23am14:C/S1 & 73 & A827 & Vavtar F & S15:19amPO:P062 & 29 & A295 \\
\hline Travin A & G01:22am06:A/St & 46 & $\mathbf{A 7 8 3}$ & Valley J & S14:18pmPO:P009 & 29 & A611 & Vazquez F & S30:18amPO:P255 & 31 & A663 \\
\hline Trayhorn S & S14:19am13:C/A2 & 14 & A195 & Valley J & G01:22am12:A/St & 46 & A144 & Vazquez JA & S16:23pm27:C/A2 & 79 & A802 \\
\hline Treble $\mathrm{P}$ & G03:19pmPO:P237 & 24 & A784 & Valley J & G05:22pmPO:P062 & 58 & A605 & Veblen D & G09:18pm21:A/Fm & 7 & A689 \\
\hline Trembaczowski A & S38:23amPO:P341 & 69 & A809 & Valley J & S16:22pmPO:P029 & 63 & A428 & Veizer J & S24:18pmPO:P212 & 31 & A411 \\
\hline Treude $\mathrm{T}$ & $\mathrm{S} 35: 21 \mathrm{am04:B/Pi}$ & 39 & A214 & Valley JW & S07:18am04:C/S2 & 3 & A125 & Vejmelka P & S39:22pmPO:P357 & 70 & A690 \\
\hline Treude $\mathrm{T}$ & $\mathrm{S} 35: 21 \mathrm{am} 07: \mathrm{B} / \mathrm{Pi}$ & 39 & A770 & Valley JW & G06:22pmPO:P169 & 59 & A386 & Veksler I & S47:19pmPO:P313 & 33 & A299 \\
\hline Tribuzio R & S16:22pmPO:P031 & 63 & A634 & Valley JW & S03:23am07:C/S1 & 73 & A794 & Veksler I & S17:22am05:C/A2 & 47 & A43 \\
\hline Trieloff $\mathbf{M}$ & S40:21am03:A/Fm & 40 & A784 & Valley JW & $\mathrm{S} 16: 23 \mathrm{pm} 26: \mathrm{C} / \mathrm{A} 2$ & 79 & A78 & Veksler I & S17:22am06:C/A2 & 47 & A803 \\
\hline Trieloff M & S40:22am13:A/Fm & 50 & A96 & Vaman B & S23:18pm30:B/Fo & 9 & A751 & Velazquez M & PLENARY:20am & 35 & A2 \\
\hline Trieloff M & S40:22am11:A/Fm & 50 & A339 & van Aarssen B & S34:22am07:B/Ja & 49 & A794 & Velo A & S48:19pmPO:P355 & 34 & A230 \\
\hline Trieloff $\mathbf{M}$ & S10:23am03:C/A1 & 73 & A785 & van Beek P & $\mathrm{S} 23: 18 \mathrm{pm} 23: \mathrm{B} / \mathrm{Fo}$ & 9 & A808 & Velo A & S48:19pmPO:P357 & 34 & A262 \\
\hline Tripa E & S01:18am06:C/S1 & 2 & A171 & van Bergen M & S14:19pm29:C/A2 & 20 & A213 & Velo A & G10:22pmPO:P280 & 60 & A803 \\
\hline Troelstra S & S44:18am12:A/St & 5 & A812 & Van Bergen MJ & S14:19pm30:C/A2 & 20 & A324 & Vengosh A & S38:22pm30:B/Ja & 56 & A804 \\
\hline Trofimovs J & S08:21am02:C/A2 & 37 & A122 & van Bergen MJ & S14:18pmPO:P012 & 29 & A796 & Vengosh A & S38:23amPO:P339 & 69 & A695 \\
\hline Trofimovs J & S08:22pmPO:P020 & 61 & A785 & van Bergen PF & G04:23pm23:B/Pi & 77 & A313 & Vennemann $\mathrm{T}$ & S24:19am12:B/Fo & 15 & A682 \\
\hline Trombetta A & G01:19pmPO:P288 & 23 & A786 & van Bronswijk W & $\mathrm{S} 45: 18 \mathrm{pm} 28: \mathrm{A} / \mathrm{Co}$ & 11 & A601 & Vennemann $\mathrm{T}$ & S12:19pmPO:P034 & 28 & A176 \\
\hline Trubkin NV & G09:18am07:A/Fm & 2 & A219 & Van Cappellen P & $\mathrm{S} 48: 19 \mathrm{am} 03: \mathrm{B} / \mathrm{Ja}$ & 17 & A62 & Vennemann TW & S49:18pmPO:P109 & 34 & A804 \\
\hline Trueman CNG & S29:19pm25:A/St & 21 & A786 & Van Cappellen P & S48:19am06:B/Ja & 17 & A843 & Vennemann TW & S28:22amPO:P220 & 67 & A789 \\
\hline Trumbull R & S14:18pmPO:P010 & 29 & A650 & Van Cappellen P & S30:18amPO:P249 & 31 & A117 & Ventura G & $\mathrm{S} 34: 22 \mathrm{am} 13: \mathrm{B} / \mathrm{Ja}$ & 49 & A393 \\
\hline Tsapin A & S33:18am14:B/Pi & 4 & A354 & Van Cappellen P & S48:19pmPO:P352 & 34 & A143 & Ver LMB & $\mathrm{G} 04: 22 \mathrm{pm} 21: \mathrm{B} / \mathrm{Pi}$ & 51 & A449 \\
\hline Tsuno H & G09:19amPO:P123 & 26 & A570 & Van Cappellen P & S48:19pmPO:P360 & 34 & A349 & Vercammen $\mathrm{K}$ & $\mathrm{S} 36: 22 \mathrm{am} 03: \mathrm{B} / \mathrm{Pi}$ & 50 & A247 \\
\hline Tsunoda $\mathrm{T}$ & G07:18pmPO:P344 & 25 & A787 & Van Cappellen P & $\mathrm{S} 19: 22 \mathrm{pm} 28: \mathrm{C} / \mathrm{S} 2$ & 53 & A505 & Verchovsky A & S40:21am10:A/Fm & 40 & A805 \\
\hline $\mathrm{Tu} \mathrm{G}$ & G10:22pmPO:P276 & 60 & A 452 & Van Cappellen P & $\mathrm{S} 19: 22 \mathrm{pm} 26: \mathrm{C} / \mathrm{S} 2$ & 53 & A628 & Verchovsky S & S05:19pm26:C/S2 & 19 & A825 \\
\hline Tuckwell GW & S19:22am04:C/S2 & 48 & A222 & Van Cappellen P & $\mathrm{S} 19: 22 \mathrm{pm} 21: \mathrm{C} / \mathrm{S} 2$ & 53 & A795 & Verchovsky S & S01:19amPO:P142 & 26 & A337 \\
\hline Turek A & G01:19pmPO:P270 & 23 & A398 & Van Cappellen P & S19:23amPO:P160 & 64 & A373 & Verri G & S29:19pm26:A/St & 21 & A805 \\
\hline Turku A & G09:18am06:A/Fm & 2 & A787 & Van Cappellen P & G04:23am07:B/Pi & 72 & A411 & Vervoort JD & S13:18am02:C/A2 & 3 & A806 \\
\hline Turner G & S01:18am08:C/S1 & 2 & A788 & van de Flierdt T & S42:18am07:B/Fo & 5 & A33 & Vervoort JD & G08:21am11:C/S1 & 36 & A682 \\
\hline Turner G & S02:18amPO:P148 & 26 & A112 & Van de Flierdt $T$ & $\mathrm{~S} 42: 18 \mathrm{am} 06: \mathrm{B} / \mathrm{Fo}$ & 5 & A142 & Veryovkin I & $\mathrm{S} 47: 19 \mathrm{am} 11: \mathrm{A} / \mathrm{St}$ & 16 & A588 \\
\hline Turner G & S01:19amPO:P142 & 26 & A337 & van de Flierdt $T$ & S42:18am03:B/Fo & 5 & A795 & Veuve $\mathrm{P}$ & $\mathrm{G} 04: 23 \mathrm{am} 05: \mathrm{B} / \mathrm{Pi}$ & 72 & A623 \\
\hline Turner G & PLENARY:20am & 35 & A5 & Van de Schootbrugge & & & & Vicenzi E & G06:22pmPO:P168 & 59 & A307 \\
\hline Turner G & $\mathrm{S} 40: 22 \mathrm{am06}: \mathrm{A} / \mathrm{Fm}$ & 50 & A312 & & $\mathrm{G} 04: 22 \mathrm{pm} 22: \mathrm{B} / \mathrm{Pi}$ & 51 & A239 & Viers J & G04:23am04:B/Pi & 72 & A609 \\
\hline Turner G & $\mathrm{S} 40: 22 \mathrm{am03:A/Fm}$ & 50 & A529 & van den Kerkhof A & G06:23am03:C/S2 & 72 & A849 & Vieth A & $\mathrm{S} 38: 22 \mathrm{pm} 25: \mathrm{B} / \mathrm{Ja}$ & 56 & A504 \\
\hline Turner G & $\mathrm{S} 40: 22 \mathrm{am} 01: \mathrm{A} / \mathrm{Fm}$ & 50 & A789 & van der Hilst R & $\mathrm{S} 10: 22 \mathrm{pm} 25: \mathrm{C} / \mathrm{A} 1$ & 52 & A12 & Vigier $\mathrm{N}$ & $\mathrm{S} 21: 21 \mathrm{am} 05: \mathrm{A} / \mathrm{Co}$ & 38 & A97 \\
\hline Turner S & $\mathrm{S} 14: 19 \mathrm{pm} 24: \mathrm{C} / \mathrm{A} 2$ & 20 & A238 & van der Meer JPM & S14:18pmPO:P012 & 29 & A796 & Vigier $\mathbf{N}$ & S21:21am06:A/Co & 38 & A806 \\
\hline Turner S & S16:23am09:C/A2 & 74 & A270 & van der Weijden $\mathrm{CH}$ & $\mathrm{S} 48: 19 \mathrm{am} 06: \mathrm{B} / \mathrm{Ja}$ & 17 & A843 & Vijaya Kumar T & G01:19pmPO:P258 & 23 & A860 \\
\hline Turner S & S16:23am08:C/A2 & 74 & A788 & Van der Weijden $\mathrm{CH}$ & S21:22pmPO:P290 & 65 & A577 & Vilas F & G10:22pmPO:P280 & 60 & A803 \\
\hline Tuross N & $\mathrm{S} 29: 19 \mathrm{pm} 25: \mathrm{A} / \mathrm{St}$ & 21 & A786 & van der Weijden $\mathrm{CH}$ & G04:23pm23:B/Pi & 77 & A313 & Viljoen F & S12:19pmPO:P035 & 28 & A420 \\
\hline Turrin B & $\mathrm{S} 31: 22 \mathrm{am} 04: \mathrm{A} / \mathrm{Co}$ & 49 & A679 & Van Dusen A & S07:19am05:C/S2 & 13 & A335 & Villa IM & S45:18am12:A/Co & 6 & A698 \\
\hline Tütken T & S28:22amPO:P220 & 67 & A789 & van Gaans P & G07:19pm25:B/Ja & 18 & A732 & Villa IM & S45:18am05:A/Co & 6 & A807 \\
\hline Tuttas D & $\mathrm{S} 44: 18 \mathrm{pm} 22: \mathrm{A} / \mathrm{St}$ & 10 & A693 & van Gaans PF & G07:18pmPO:P346 & 25 & A796 & Villa IM & G01:19pmPO:P279 & 23 & A651 \\
\hline Tuttas D & S44:19amPO:P303 & 33 & A789 & van Keken P & S10:22amPO:P137 & 62 & A797 & Villa IM & G08:19pmPO:P157 & 25 & A280 \\
\hline \multirow[t]{11}{*}{ Tuyukina T } & G04:23pm28:B/Pi & 77 & A790 & Van Kranendonk M & S07:18am11:C/S2 & 3 & A101 & Villar MP & S48:19pmPO:P355 & 34 & A230 \\
\hline & & & & Van Lith Y & $\mathrm{S} 19: 22 \mathrm{pm} 26: \mathrm{C} / \mathrm{S} 2$ & 53 & A628 & Villar MV & G10:22pmPO:P278 & 60 & A694 \\
\hline & & & & van Oort F & $\mathrm{S} 37: 21 \mathrm{am} 05: \mathrm{B} / \mathrm{Ja}$ & 39 & A142 & Villegas-Jiménez A & G09:19amPO:P130 & 26 & A807 \\
\hline & & & & Van Orman JA & S11:19am03:C/A1 & 14 & A659 & Violette S & S38:23amPO:P334 & 69 & A265 \\
\hline & & & & van Riemsdijk W & $\mathrm{S} 37: 21 \mathrm{pm} 24: \mathrm{B} / \mathrm{Ja}$ & 45 & A67 & Viollier E & S23:18pm23:B/Fo & 9 & A808 \\
\hline & & & & van Riemsdijk W & S37:21pm22:B/Ja & 45 & A797 & Visonà D & S16:22pmPO:P030 & 63 & A486 \\
\hline & & & & van Zuilen M & S07:18am08:C/S2 & 3 & A448 & Visscher PT & S49:19am05:A/Fm & 17 & A808 \\
\hline & & & & van Zuilen M & S07:18am10:C/S2 & 3 & A798 & Viti C & G01:19pmPO:P264 & 23 & A182 \\
\hline & & & & Van Keken PE & $\mathrm{S} 10: 23 \mathrm{am} 04: \mathrm{C} / \mathrm{A} 1$ & 73 & A47 & Vitorge $\mathrm{P}$ & S48:19pmPO:P353 & 34 & A179 \\
\hline & & & & VanCalsteren P & $\mathrm{S} 29: 19 \mathrm{pm} 29: \mathrm{A} / \mathrm{St}$ & 21 & A604 & Viville D & S22:22amPO:P307 & 65 & A615 \\
\hline & & & & Vance D & $\mathrm{S} 44: 18 \mathrm{am} 03: \mathrm{A} / \mathrm{St}$ & 5 & A771 & Vladimirov V & S20:19pm28:A/Co & 20 & A791 \\
\hline Uchida M & G04:22amPO:P255 & 57 & A791 & Vance D & S42:19amPO:P220 & 32 & A67 & Voegelin A & G07:19am13:B/Ja & 12 & A346 \\
\hline Uchimiya M & $\mathrm{S} 36: 21 \mathrm{pm} 25: \mathrm{B} / \mathrm{Pi}$ & 44 & A & Vance D & $\mathrm{S} 26: 22 \mathrm{pm} 23: \mathrm{B} / \mathrm{Fo}$ & 54 & A694 & Voegelin A & G07:19pm24:B/Ja & 18 & A417 \\
\hline Udin D & S20:19pm28:A/Co & 20 & A791 & Vance D & S41:23am05:A/Fm & 76 & A26 & Vogel N & S40:21am08:A/Fm & 40 & A809 \\
\hline Udin D & G01:22am06:A/St & 46 & A783 & Vance D & S28:23pm26:B/Fo & 80 & A798 & Voigt D & S12:18pm21:C/A2 & 9 & A829 \\
\hline Ukawa M & S16:22pmPO:P033 & 63 & A778 & Vanhaecke F & S20:19am11:A/Co & 15 & A517 & Voitel L & $\mathrm{S} 23: 18 \mathrm{pm} 23: \mathrm{B} / \mathrm{Fo}$ & 9 & A808 \\
\hline Ulfbeck D & S44:19amPO:P304 & 33 & A792 & Vanhala H & S02:18pm28:C/S1 & 7 & A799 & Voitenko D & G05:21pm24:C/A1 & 41 & A813 \\
\hline Urata K & G06:22pmPO:P165 & 59 & A250 & Vanko D & $\mathrm{S} 17: 22 \mathrm{pm} 30: \mathrm{C} / \mathrm{A} 2$ & 53 & A41 & Vokal B & G07:18pmPO:P327 & 24 & A191 \\
\hline Urs S & S04:23amPO:P146 & 61 & A9 & Vannucci R & S15:18am05:C/A1 & 4 & A775 & Vokal B & G03:19pmPO:P231 & 24 & A460 \\
\hline & $\mathrm{S} 23 \cdot 19 \mathrm{pmPO} \cdot \mathrm{P} 205$ & 30 & A269 & Vannucci R & $\mathrm{S} 11: 18 \mathrm{pm} 29: \mathrm{C} / \mathrm{A} 1$ & 8 & A143 & Vokal B & $\mathrm{G} 09 \cdot 19 \mathrm{amPO} \cdot \mathrm{P} 116$ & 25 & \\
\hline
\end{tabular}


Goldschmidt 2002 Index

Author

Code

S38:23amPO:P341

$\mathrm{S} 20: 18 \mathrm{pmPO}: \mathrm{P027}$

von Blanckenburg F S21:21 am14:A/Co

Von Blanckenburg F S21:21pm23:A/Co

von Blanckenburg F S41:22pm26:A/Fm

von Blanckenburg F S41:22pm23:A/Fm

von Blanckenburg F S21:22pmPO:P291

von Blanckenburg F S28:22amPO:P217

von Blanckenburg F S41:22amPO:P104

von der Handt A S11:18pm31:C/A1

von der Handt A S11:18amPO:P052

von Gunten U

von Gunten U

von Gunten U

von Quadt A

von Quadt A

von Quadt A

Vrabec M

Vreca $\mathbf{P}$

Vriend S

Vriend $\mathrm{S}$

Vroon $\mathrm{P}$

Vroon P

Vroon PZ

Vrublevsky V

Vrublevsky V

Vshivkov V

S48:18am10:B/Ja

S31:22am03:A/Co

S41:23am 14:A/Fm

G01:19pmPO:P276

G01:19pmPO:P289

G05:22pmPO:P052

G05:22pmPO:P068

S30:19am06:B/Pi

G07:19am11:B/Ja

G07:19pm25:B/Ja

S44:18am12:A/St

S14:18pmPO:P012

G05:21pm24:C/A1

S17:23amPO:P007

S02:18amPO:P153
S44:18am11:A/St

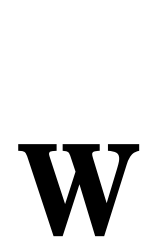

Waber H

Waber HN

Wada H

Wade J

Wadhwa M

Wadhwa M

Wagner C

Wagner C

Wagner C

Waight $\mathrm{T}$

Waight $T$

Waight $\mathrm{T}$

Wake C

Walczyk T

Waldner P

Walker J

Walker R

Walker R

Walker RJ

Wall F

Wall J

Wallace $\mathbf{P}$

Wallace $\mathbf{P}$

Walter $\mathbf{L}$

Walter LM

Walter M

Wampler JM

Wan D

Wan G

Wang C

Wang $\mathrm{F}$

Wang $\mathrm{F}$

Wang $\mathrm{H}$

Wang $\mathbf{J}$

Wang J

Wang J

Wang $\mathrm{J}$

Wang $\mathrm{P}$

Wang $\mathbf{P}$

Wang $\mathrm{S}$

Wang S

Wang S

Wang S

Wang S

Wang S

31:22pm24:A/Co

S19:22am01:C/S2

G03:21pm24:B/Fo

S09:22am03:C/A1

G08:21am08:C/S1

S03:23am13:C/S1

S11:18amPO:P045

G05:22pmPO:P072

S16:22pmPO:P034

S44:18am04:A/St

G05:21am07:C/A1

G05:22pmPO:P056

S43:22pmPO:P267

$\mathrm{S} 41: 22 \mathrm{pm} 23: \mathrm{A} / \mathrm{Fm}$

G04:22amPO:P256

S14:19am10:C/A2

S02:18pm30:C/S1

S08:21pm25:C/A2

S08:21pm26:C/A2

S12:19pmPO:P043

S35:19amPO:P246

S14:19am09:C/A2

S17:22am12:C/A2

G04:22pm30:B/Pi

G04:23pm26:B/Pi

S41:23am07:A/Fm

S45:19amPO:P033

S22:23am07:A/Co

G03:19pmPO:P226

S22:23am07:A/Co

G03:19pmPO:P239

G04:23pm25:B/Pi

G03:19pmPO:P240

G09:18am02:A/Fm

$\mathrm{S} 43: 21 \mathrm{am} 07: \mathrm{A} / \mathrm{St}$

G08:21pm25:C/S1

G10:22pmPO:P276

S07:18pm24:C/S2

G08:21am04:C/S1

G03:19pmPO:P230

G09:19amPO:P117

G09:19amPO:P129

G09:19amPO:P131

G09:19amPO:P119

G04:22amPO:P246
Prog. Abs. Author

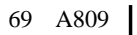

Wang S

A615 Ward J

38 A673 Ward J

44 A327 Warneke T

56 A715

Warner JA

56 A810 Warren JM

65 A591

7 A392

\begin{tabular}{ll|l}
71 & A834 Wartho J
\end{tabular}

8 A810 Wartho J

27 A722 Warton B

6 A509 Warwick P

49 A334 Warwick P

76 A769 Warwick PE

23 A573 Warwick PE

23 A811 Wasserburg G

58 A380 Wasserburg GJ

58 A811

$16 \quad \mathbf{8 1 2}$

12 A347 Watson B

18 A732 Watson B

5 A97 Watson JS

5 A812 Webb L

29 A796 Weber B

41 A813 Weber $h$

63 A608 Weber P

26 A724 Weber PK

Weber PK

Webster J

Wefer G

Wehrli B

Wehrli B

Wehrli B

Wehrli B

Wehrli B

Wehrli B

Wehrli B

Weidler PG

Weidler PG
$55 \quad$ A779

48 A473

$41 \quad \mathbf{A 8 1 5}$

$\begin{array}{ll}47 & \mathbf{A 8 1 5}\end{array}$

36 A158

$73 \quad \mathbf{A 8 1 6}$

27 A96

59 A876

63 A816

5 A44

$\begin{array}{ll}36 & \mathbf{A 8 1 7}\end{array}$

58 A433

$71 \quad$ A418

56 A810

57 A817

14 A703

7 A60

43 A818

43 A309

28 A868

$32 \quad$ A498

$14 \quad \mathbf{A 1 2 6}$

$\begin{array}{ll}47 & \mathbf{A 8 1 8}\end{array}$

11 A757

$77 \quad$ A522

76 A288

33 A819

74 A185

24 A134

74 A185

24 A820

77 A454

24 A820

2 A

$40 \quad$ A85

42 A819

60 A452

8 A64

$36 \mathbf{A 8 2 1}$

24 A454

25 A367

26 A136

26 A821

26 A851

57 A572
Weidner D

Weinberger $\mathrm{R}$

Weiner $\mathbf{S}$

Weiner S

Weis D

Weis D

Weis D

Weiss B

Weiss D

Weiss D

Weissert $\mathrm{H}$

Welch S

Wellman D

Welsch S

Wen C

Wen $\mathrm{H}$

Werner C

Werner D

Werner M

Wernli B

Wersin $\mathrm{P}$

Wesolowski D

Westall $\mathbf{F}$

Westall F

Westman P

Westphal E

Wettstein B

Weyer $\mathbf{S}$

Weyer S

Weyer S

Weyer S

Weyer S

G04:23pm21:B/P

Wheat CG S19:23amPO:P158

Wheat $\mathrm{G}$

Wheat $\mathrm{G}$

Whitby J

White A

White A

White A

White J

White J

White N

G04:22amPO:P246

$\mathrm{S} 33 \cdot 18 \mathrm{am} 11 \cdot \mathrm{B} / \mathrm{Pi}$

$\mathrm{S} 33: 18 \mathrm{am} 10: \mathrm{B} / \mathrm{Pi}$

$\mathrm{S} 44: 18 \mathrm{pm} 25: \mathrm{A} / \mathrm{St}$

S11:18amPO:P056

S49:18pmPO:P108

$\mathrm{S} 41: 23 \mathrm{pm} 23: \mathrm{A} / \mathrm{Fm}$

20:19pm 25:A/Co

S34:23amPO:P319

44:18pm25:A/St

G07:18pmPO:P347

S44:19amPO:P305

$\mathrm{S} 21: 21 \mathrm{am} 07: \mathrm{A} / \mathrm{Co}$

$\mathrm{S} 22: 23 \mathrm{pm} 32: \mathrm{A} / \mathrm{Co}$

S02:18pm26:C/S1

S07:19pmPO:P173

S11:18pm26:C/A1

49:19am11:A/Fm

S21:21pm24:A/Co 
Goldschmidt 2002 Index$$
\text { . }
$$

Author

Code

Prog. Abs.

Author

Code

Prog. Abs.

Workman

S16:23am14:C/A2

G04:22amPO:P234

S12:19pmPO:P042

Wright I

Wright I

Wright I

Wright J

Wu G

$\mathrm{S} 40: 21 \mathrm{am} 10: \mathrm{A} / \mathrm{Fm}$

$\mathrm{S} 24: 19 \mathrm{pm} 24: \mathrm{B} / \mathrm{Fo}$

S17:23amPO:P013

Wyndham T

G07:19pm 21:B/J

Wysoczanski R S12:19pmPO:P042

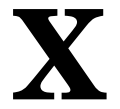

Xiao C

Xiao H

Xiao Y

Xie G

Xie $\mathrm{H}$

Xie Q

Xie S

Xifra I

Xioming Liu

Xiong X

Xu S

Xu S

$\mathrm{XuX}$

$\mathrm{XuX}$

Xu Z

$\mathrm{Xu} \mathrm{Z}$

$\mathrm{Xu} \mathrm{Z}$

Xue H

Xue X

Xue X
S18:22pmPO:P154 G07:19pm22:B/Ja G06:23am03:C/S2 G09:19amPO:P132 G09:18pm23:A/Fm S44:18am05:A/St S10:22pm30:C/A1 S48:19pmPO:P365 G09:19amPO:P119 G05:21pm31:C/A1 $\mathrm{S} 34: 22 \mathrm{am} 08: \mathrm{B} / \mathrm{Ja}$ S19:22pm24:C/S2 G03:19pmPO:P241 G05:22pmPO:P072 G05:22pmPO:P070 G05:22pmPO:P071 S21:22pmPO:P293 S30:19pm23:B/Pi G09:18am13:A/Fm G05:21pm23:C/A1

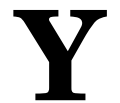

Yablonsky G

Yabuki S

Yabuki S

Yabuki S

Yabuta H

Yakovlev OI

Yakovlev OI

Yakovleva S

Yamada K

Yamada M

Yamada M

Yamada R

Yamaguchi A

Yamaguchi K

Yamamoto J

Yamamoto $\mathrm{K}$

Yamamoto K

Yamamoto $\mathrm{K}$

Yamane M

Yamashita $\mathrm{K}$

Yan $\mathrm{H}$

Yanagi $T$

Yanagi $T$

Yanagisawa $\mathrm{F}$

Yanase $\mathrm{N}$

Yang DJ

Yang J

Yang J

Yang L

Yang L
S02:18amPO·P153 S49:18pmPO:P101 S27:23amPO:P227 S27:23amPO:P229 G04:22amPO:P258 S03:22am 15:C/S1 S04:23pm25:C/S1 G01:19pmPO:P281 G01:19pmPO:P290 S23:19pmPO:P210 S42:19amPO:P219 G01:19pmPO:P275 $\mathrm{S} 40: 21 \mathrm{am} 07: \mathrm{A} / \mathrm{Fm}$ S07:19pmPO:P173 S40:22am12:A/Fm S42:19amPO:P225 S36:23amPO:P265 S39:22pmPO:P362 $\mathrm{S} 24: 19 \mathrm{pm} 27: \mathrm{B} / \mathrm{Fo}$ S03:22pm29:C/S1 G07:18pmPO:P329 S14:18pmPO:P013 S27:23amPO:P224 S27:23amPO:P227 S37:23amPO:P328 S17:23amPO:P011 S20:19am10:A/Co S22:22amPO:P300 S39:22pmPO:P354 $\mathrm{S} 39: 23 \mathrm{am} 12: \mathrm{B} / \mathrm{Ja}$

$\begin{array}{lr}13 & \text { A847 } \\ 74 & \mathrm{~A} 273 \\ 57 & \mathrm{~A} 95 \\ 28 & \mathrm{~A} 848 \\ 36 & \mathrm{~A} 45 \\ 40 & \mathrm{~A} 805 \\ 21 & \mathrm{~A} 438 \\ 63 & \mathrm{~A} 848 \\ 39 & \mathrm{~A} 687 \\ 18 & \mathrm{~A} 499 \\ 28 & \mathrm{~A} 848\end{array}$

\section{Yang R}

Yang $\mathrm{T}$

Yang $T$

Yao L

Yao L

Yasui M

Yaxley G

Yaxley GM

Ye $\mathbf{L}$

Ye L

Ye Q

Ye Q

Ye W

Yeats C

Yechieli Y

Yee $\mathrm{N}$

Yee $\mathrm{N}$

Yee $\mathbf{N}$

Yeh G

Yilmaz H

Yin Q

Yin Q

$64 \quad \mathrm{~A} 845$

Yiou $F$

$\begin{array}{llll}18 & \mathbf{A 8 4 9} & \text { Yiou F }\end{array}$

\begin{tabular}{ll|l}
72 & A849 & Yiou $\mathrm{P}$
\end{tabular}

26 A296 Yoder Jr H

7 A879 Yogo S

5 A850 $\quad$ Yogo $S$

52 A759 Yokochi R

34 A850 Yokoyama T

26 A851

41 A874

49 A753

53 A361

$24 \quad$ A852

59 A876

59 A872

$59 \quad$ A 873

65 A851

$\begin{array}{ll}22 & \mathbf{A 8 5 2}\end{array}$

$2 \quad \mathbf{A 8 5 3}$

$41 \quad \mathbf{A 3 8 2}$

Yokoyama Y

Yokoyama Y

Yoneda M

Yoshida $\mathrm{H}$

Yoshida $\mathrm{H}$

Yoshida T

You C

Young E

Young J

Young S

Yu LT

Yu Y

Yudin D

Yudintsev S

Yung-Ching $\mathrm{C}$

Yurimoto $\mathrm{H}$

Yurur T

26 7724

34 A248

67 A381

$67 \quad$ A855

57 A855

46 A185

$78 \quad \mathrm{~A} 271$

$23 \quad$ A664

$23 \quad$ A856

$30 \quad$ A856

32 A24

$23 \quad$ A537

40 A206

$27 \quad$ A857

$50 \quad \mathbf{A 8 5 8}$

32 A762

$68 \quad$ A 857

$70 \quad$ A 865

$21 \quad$ A564

52 A863

24 A229

$29 \quad$ A 858

67 A 305

67 A381

69 A249

$63 \quad$ A674

15 A875

65 A453

$70 \quad$ A577

$75 \quad$ A192

Zabel M

Zachara J

Zachara J

Zachara JM

Zachos J

Zack T

Zagorsky V

Zaidan O

Zaitsev A

Zanda B

Zanda B

Zanda B

Zanetti A

Zanetti A

Zanetti A

Zangooi A

Zartman R

Zartman RE

G04:22amPO:P246

S13:19amPO:P020

S40:21pm23:A/Fm

G08:21pm28:C/S1

G08:21pm23:C/S1

S16:22pmPO:P033

S11:18pm24:C/A1

S15:18am06:C/A1

G08:21pm24:C/S1

G05:22pmPO:P057

S35:19amPO:P246

S35:19amPO:P247

S27:23amPO:P229

S17:22pm30:C/A2

S31:22am09:A/Co

$\mathrm{S} 48: 19 \mathrm{am} 04: \mathrm{B} / \mathrm{Ja}$

$\mathrm{S} 37: 21 \mathrm{pm} 31: \mathrm{B} / \mathrm{J}$

S37:21pm32:B/Ja

S13:19amPO:P020

G05:22pmPO:P069

S03:22pm31:C/S1

S03:22pm29:C/S1

S28:22amPO:P219

$\mathrm{S} 28: 23 \mathrm{am} 11: \mathrm{B} / \mathrm{Fo}$

G04:22amPO:P240

S34:23amPO:P314

S36:23amPO:P265

S39:22pmPO:P362

S40:22pmPO:P111

S14:18pmPO:P014

$\mathrm{S} 28: 23 \mathrm{pm} 25: \mathrm{B} / \mathrm{Fo}$

46:23pm28:A/St

G04:22amPO:P255

S36:23amPO:P265

S39:22pmPO:P362

S16:22pmPO:P033

S13:19amPO:P020

S02:19am07:C/S1

S49:19am04:A/Fm

S36:22am14:B/Pi

G03:19pmPO:P230

G07:18pmPO:P350

S20:18pmPO:P027

S39:22pmPO:P363

S49:19am03:A/Fm

G09:18am 11:A/Fm

G05:22pmPO:P067

Zakaznova-ILakovleva

S18:21pm23:C/S 


\section{Goldschmidt 2002}

\section{Overviews of Oral Presentations}




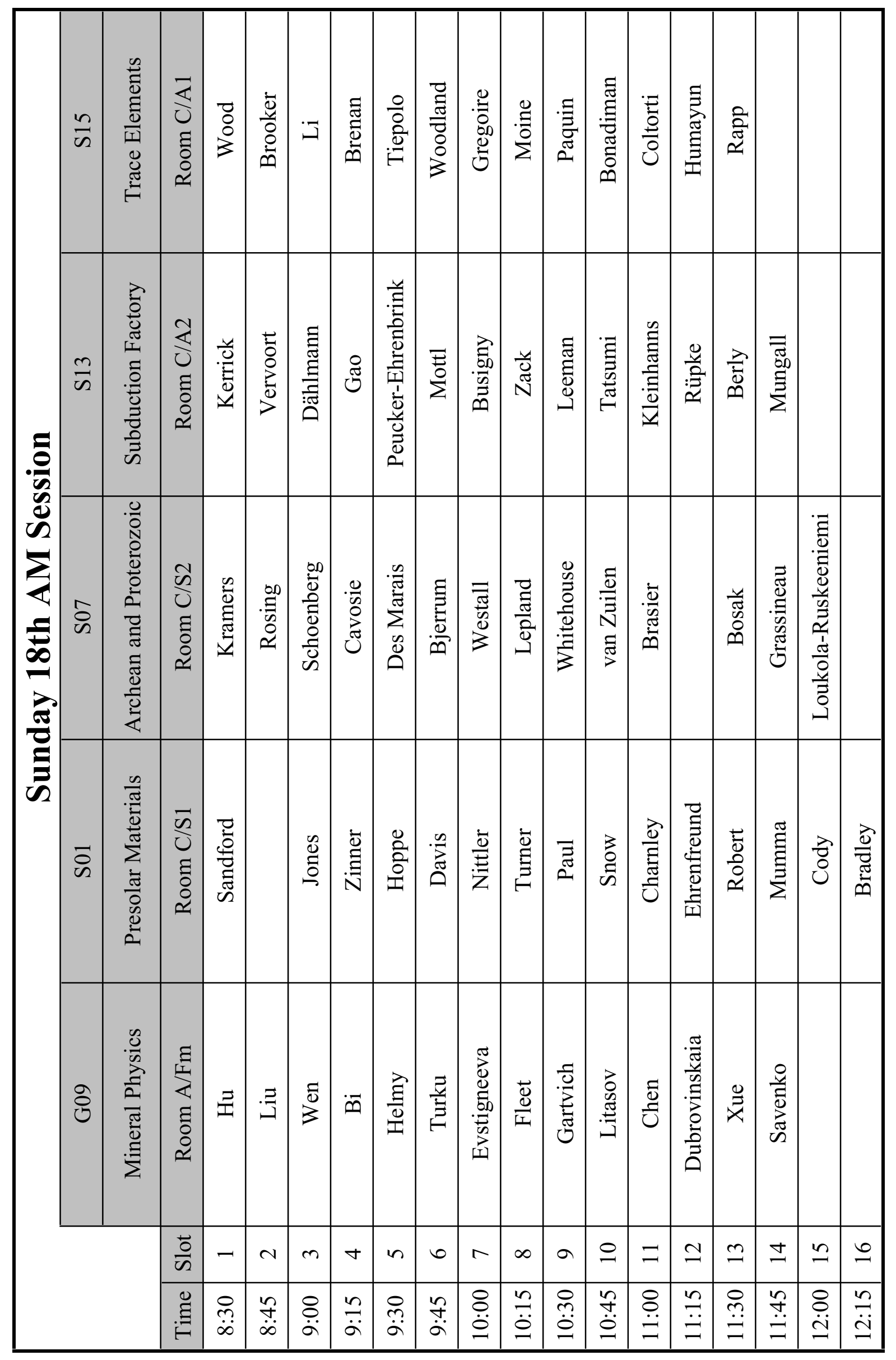




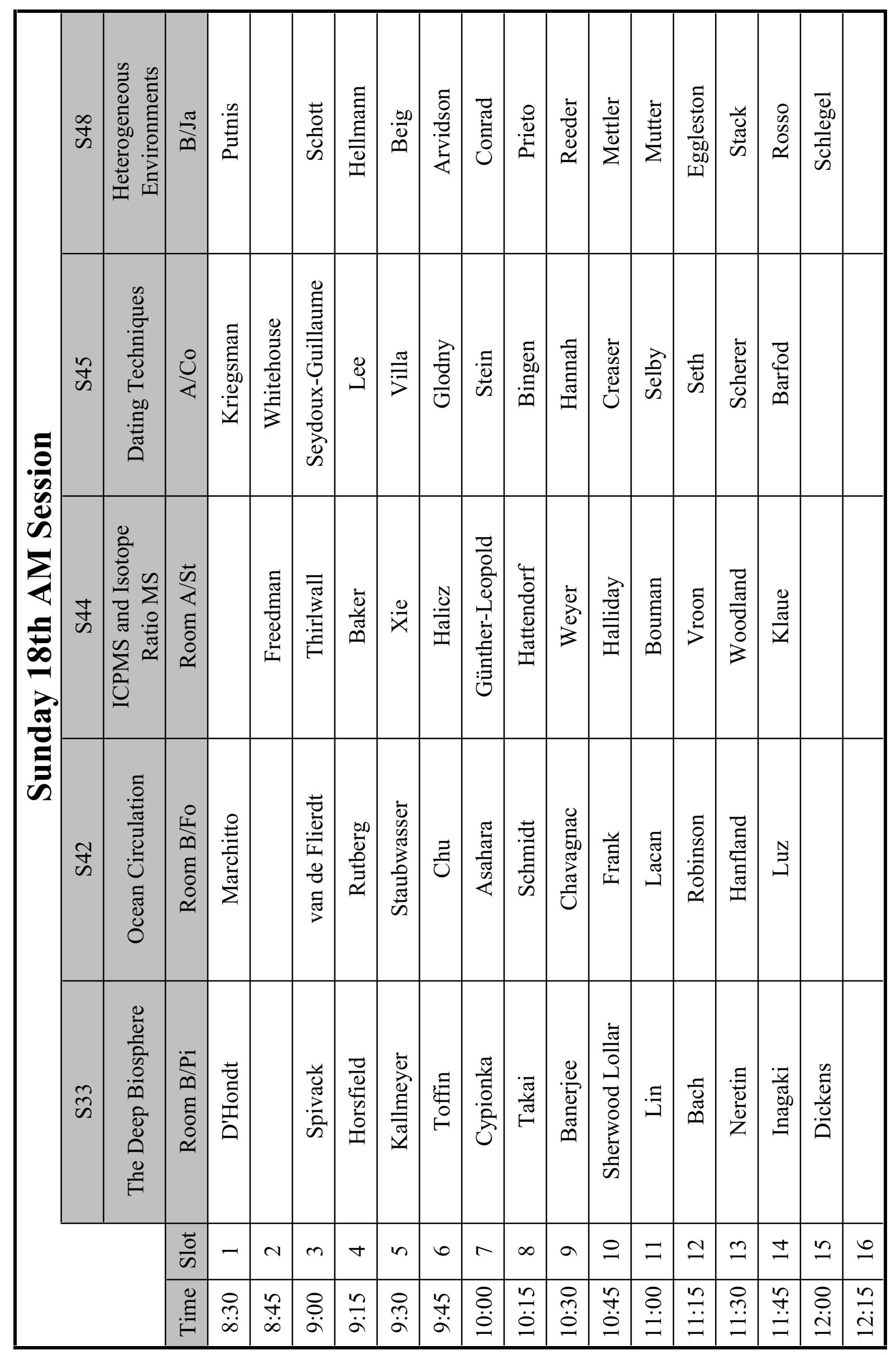




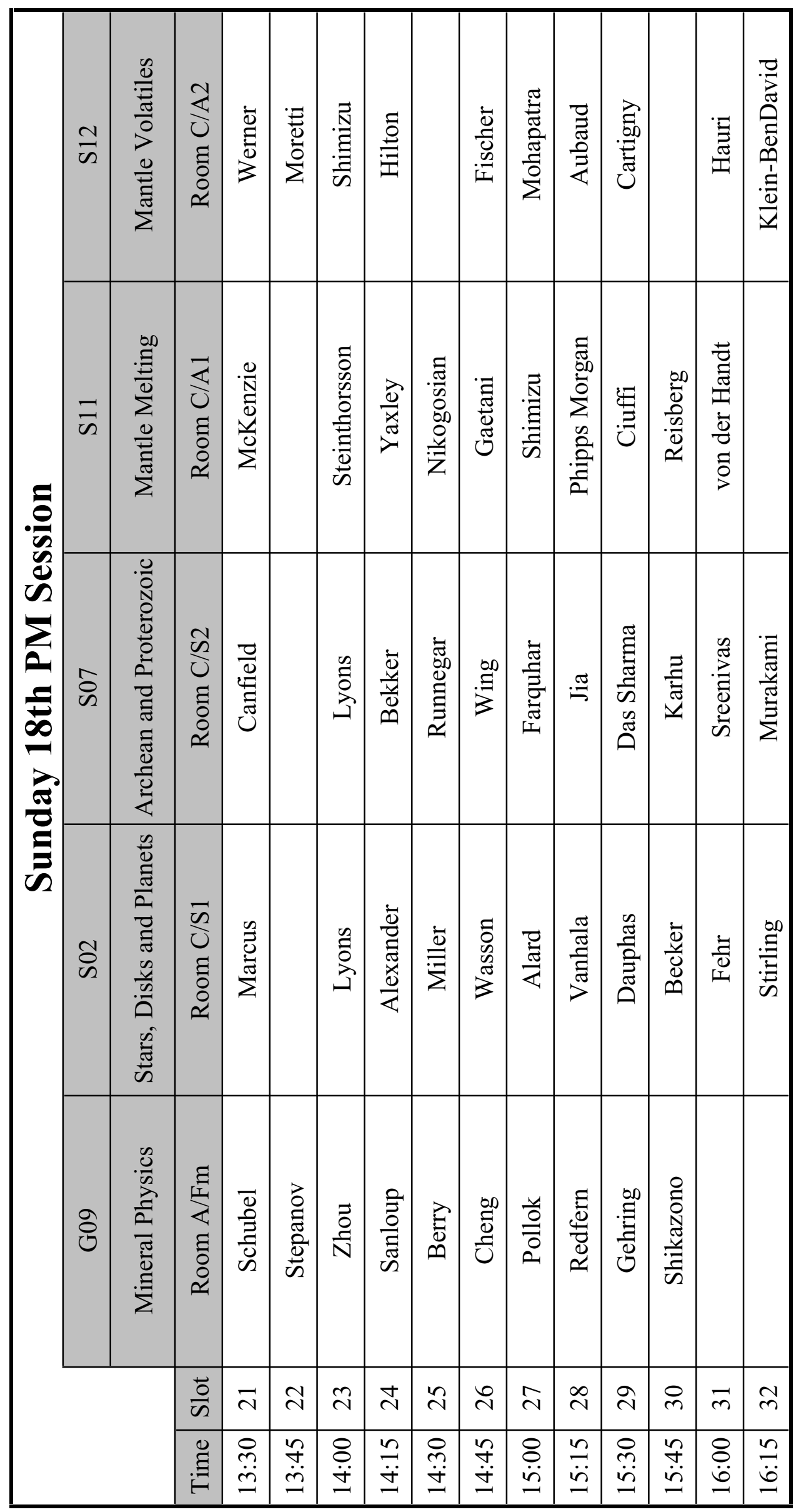




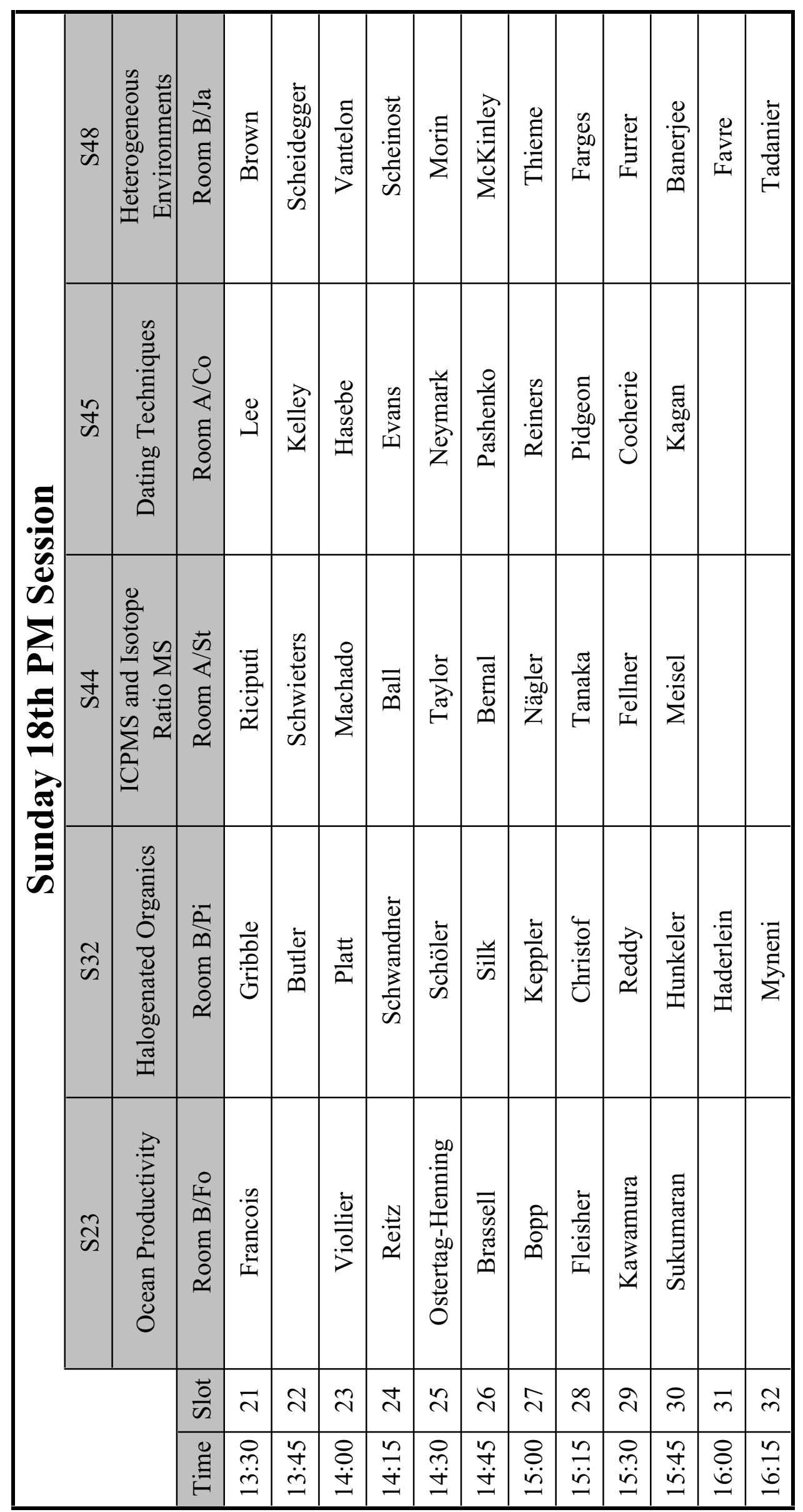




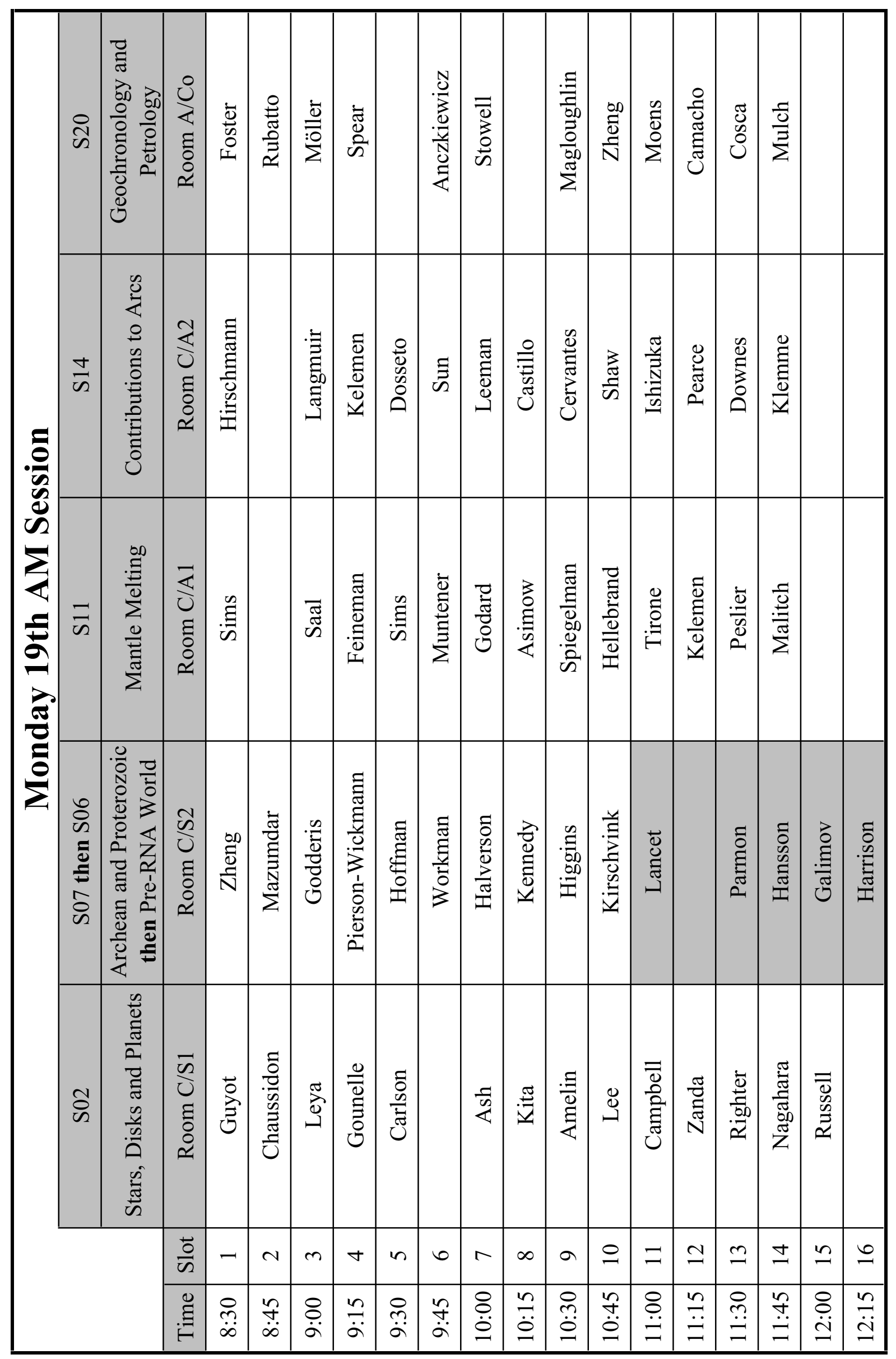




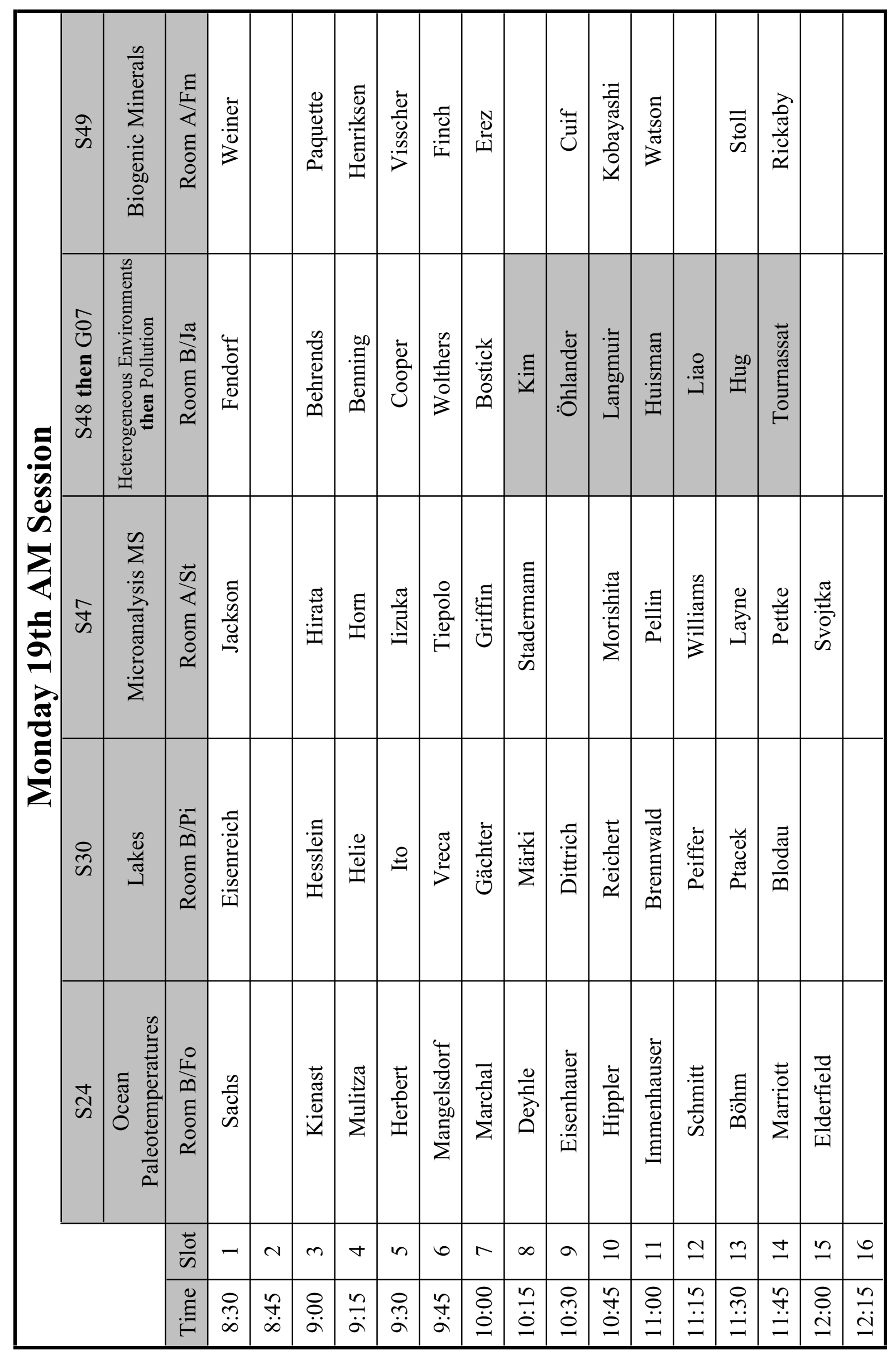




\begin{tabular}{|c|c|c|c|c|c|c|c|c|c|c|c|c|c|c|c|}
\hline \multirow{7}{*}{ 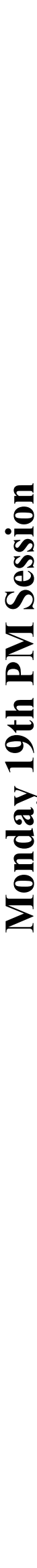 } & $\frac{\nabla}{\Delta}$ & 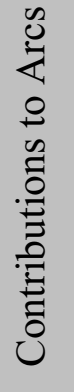 & $\begin{array}{l}\frac{1}{\Delta} \\
0 \\
\Xi \\
0 \\
\approx\end{array}$ & \begin{tabular}{l}
0 \\
\multirow{0}{0}{} \\
$\dot{0}$
\end{tabular} & & 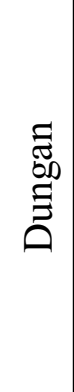 & $\begin{array}{l}\tilde{0} \\
\frac{\tilde{d}}{0} \\
\end{array}$ & 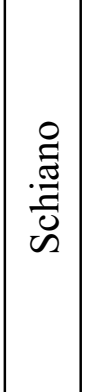 & 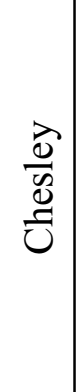 & 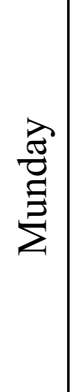 & 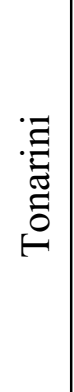 & 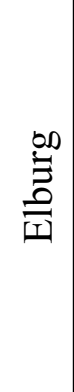 & 声 & & \\
\hline & $\overline{\bar{n}}$ & 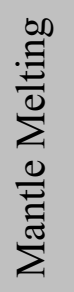 & $\begin{array}{l}\bar{\Xi} \\
0 \\
\Xi \\
0 \\
0\end{array}$ & 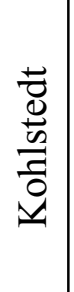 & & $\begin{array}{l}\vec{\circlearrowright} \\
\stackrel{\Xi}{0} \\
\ominus \\
\ominus\end{array}$ & 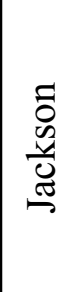 & 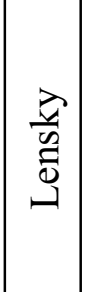 & 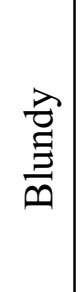 & 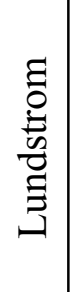 & 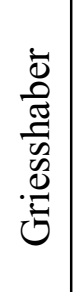 & $\begin{array}{l}\bar{E} \\
\stackrel{\bar{E}}{ \pm}\end{array}$ & $\mid \begin{array}{l}\infty \\
\stackrel{0}{\Xi} \\
\tilde{\Xi} \\
\varkappa\end{array}$ & 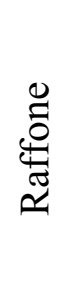 & \\
\hline & 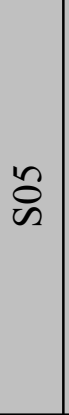 & 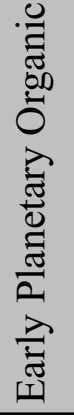 & 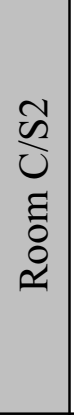 & $\begin{array}{l}\frac{0}{0} \\
\stackrel{0}{ \pm} \\
\Sigma \\
\Sigma\end{array}$ & & 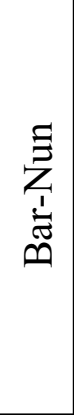 & 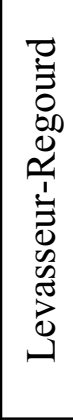 & 咅 & 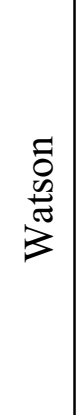 & 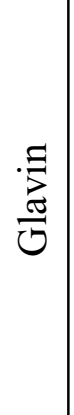 & 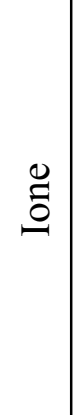 & 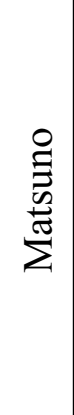 & $\begin{array}{l}\text { ü } \\
\text { : } \\
\text { : }\end{array}$ & 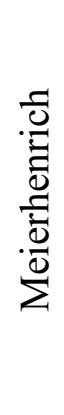 & \\
\hline & 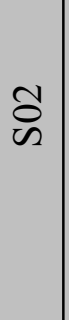 & 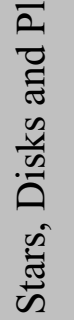 & 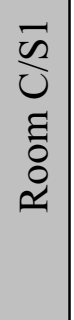 & & ڤ్ల & & 莺 & \begin{tabular}{|l}
$\bar{\Xi}$ \\
DII
\end{tabular} & 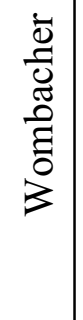 & 䓌 & 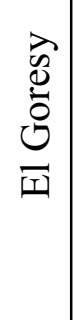 & $\overline{\bar{D}}$ & & & \\
\hline & 今̊ & 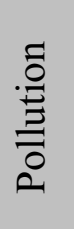 & 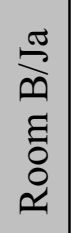 & 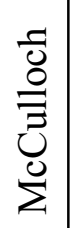 & 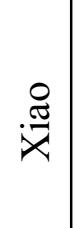 & 总 & 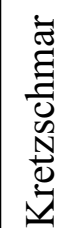 & 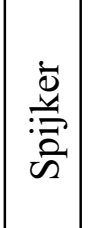 & 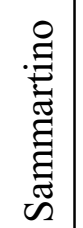 & $\begin{array}{l}\text {. } \\
0 \\
0 \\
0 \\
0 \\
0 \\
0\end{array}$ & 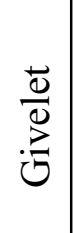 & $\vec{\Xi}$ & 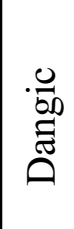 & & \\
\hline & & & $\frac{\overrightarrow{0}}{\omega}$ & $\vec{\sim}$ & $\widetilde{\sim}$ & $\ddot{\sim}$ & $\stackrel{\sim}{\sim}$ & $\tilde{a}$ & $\stackrel{\sim}{\sim}$ & $\hat{\sim}$ & $\stackrel{\infty}{\sim}$ & 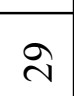 & in & $\bar{m}$ & $\approx$ \\
\hline & & & $\stackrel{\mathscr{\Xi}}{\Xi}$ & $\begin{array}{l}0 \\
\ddot{n} \\
\ddot{n}\end{array}$ & $\begin{array}{l}\stackrel{n}{\sim} \\
\ddot{n}\end{array}$ & $\begin{array}{l}8 \\
\stackrel{+}{\dot{I}} \\
\text {. }\end{array}$ & $\begin{array}{l}n \\
\ddot{\dot{I}}\end{array}$ & $\begin{array}{l}\stackrel{\overbrace{}}{\dddot{\Xi}} \\
\stackrel{ \pm}{\forall}\end{array}$ & \begin{tabular}{l|}
$\mathfrak{y}$ \\
$\dot{ \pm}$ \\
\end{tabular} & $\begin{array}{l}8 \\
\dot{\varphi} \\
\ddot{n}\end{array}$ & $\begin{array}{l}\ddot{n} \\
\ddot{\ddot{n}}\end{array}$ & $\begin{array}{l}\stackrel{0}{n} \\
\ddot{n}\end{array}$ & $\begin{array}{l}\stackrel{n}{\ddot{n}} \\
\ddot{n}\end{array}$ & $\stackrel{8}{\stackrel{8}{\circ}}$ & $\frac{n}{\ddot{6}}$ \\
\hline
\end{tabular}




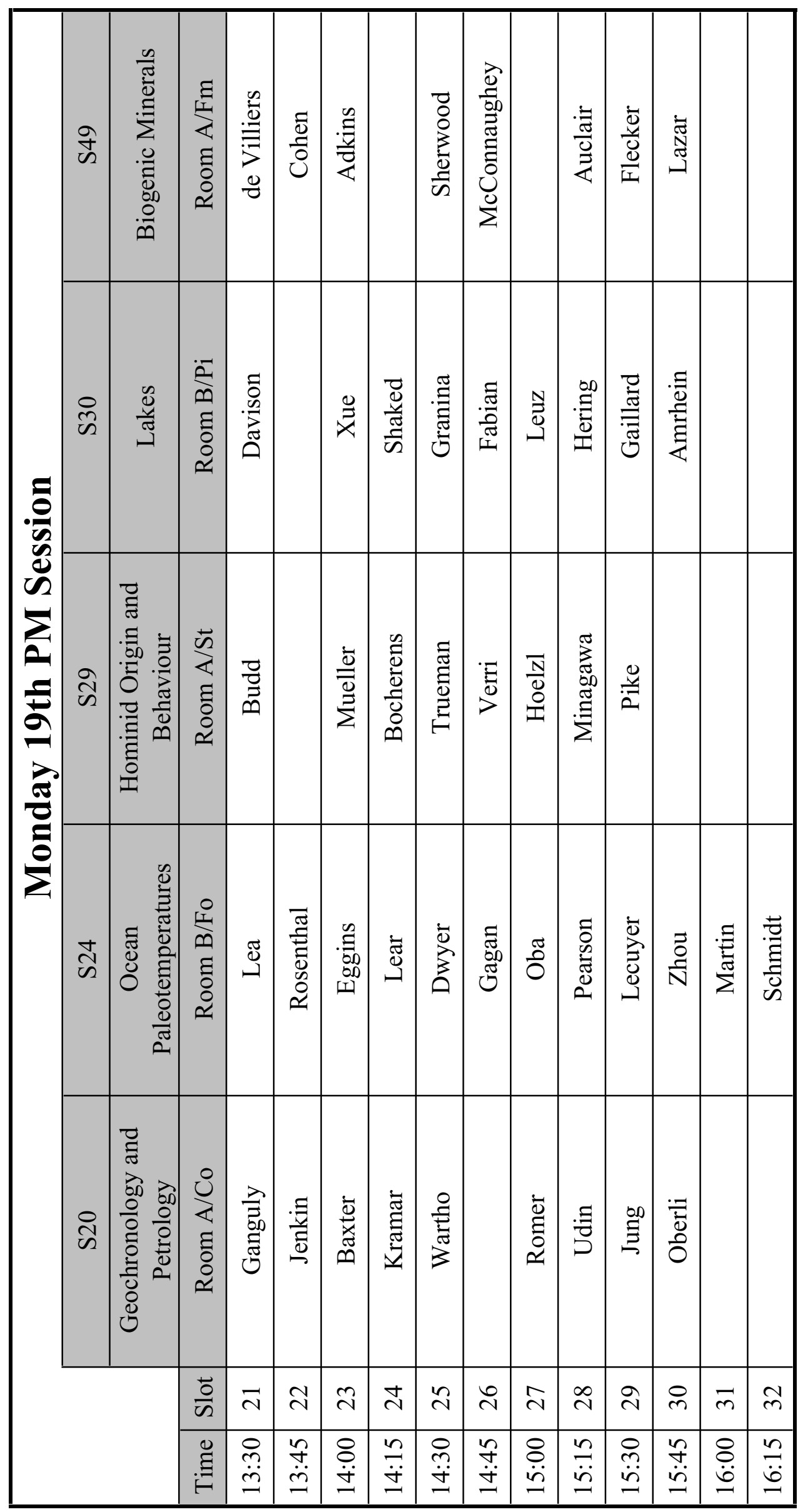




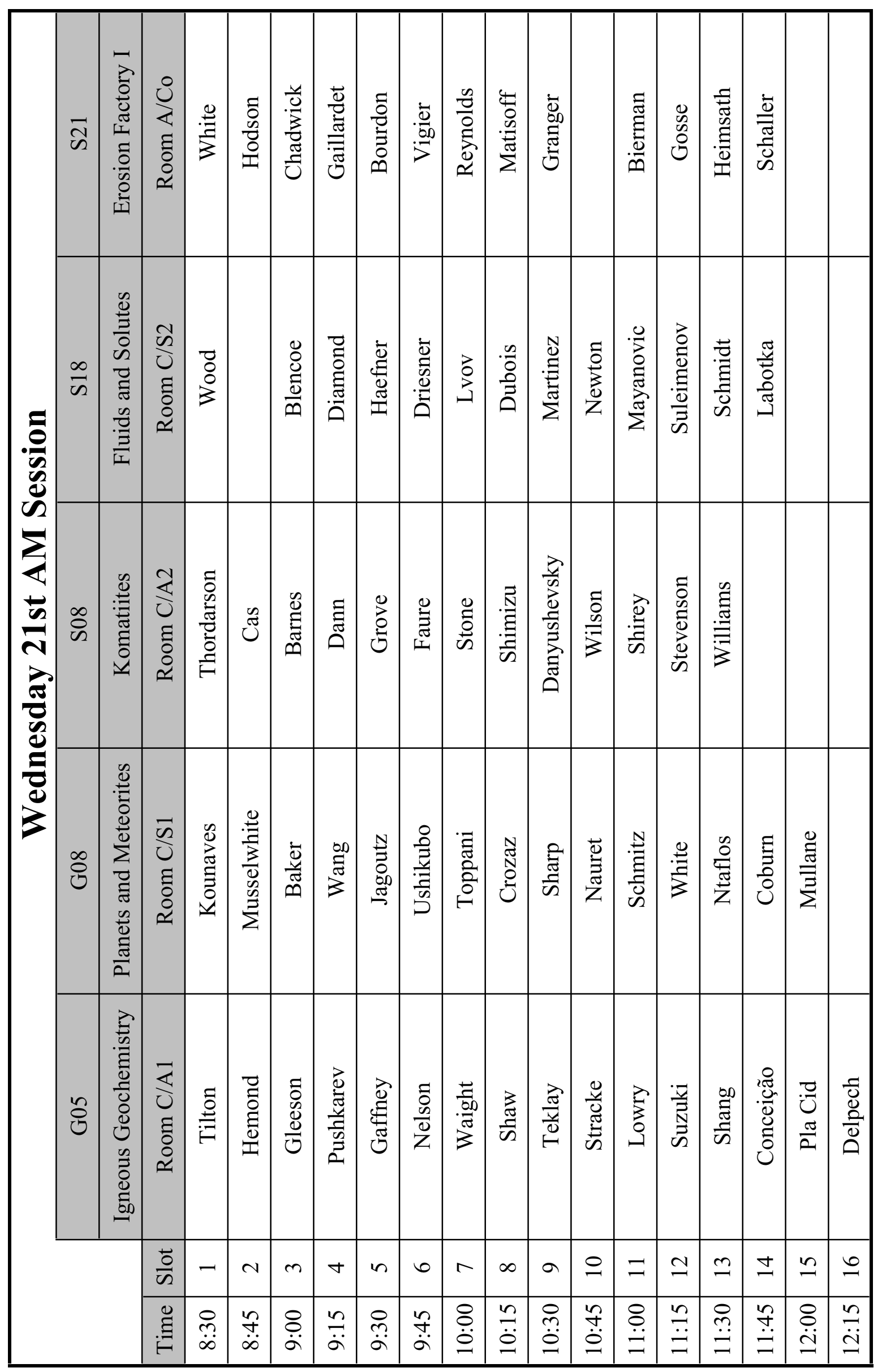




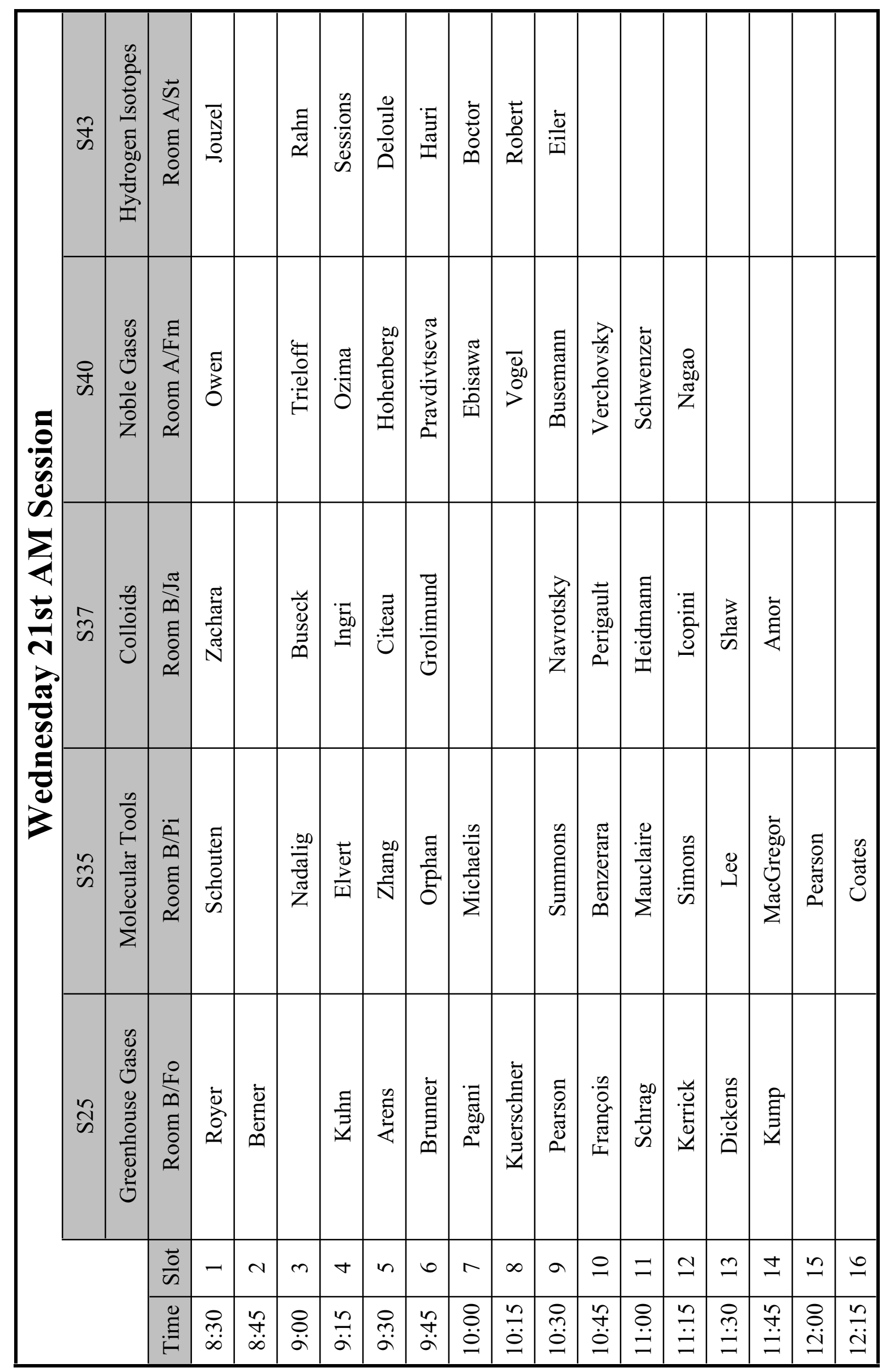




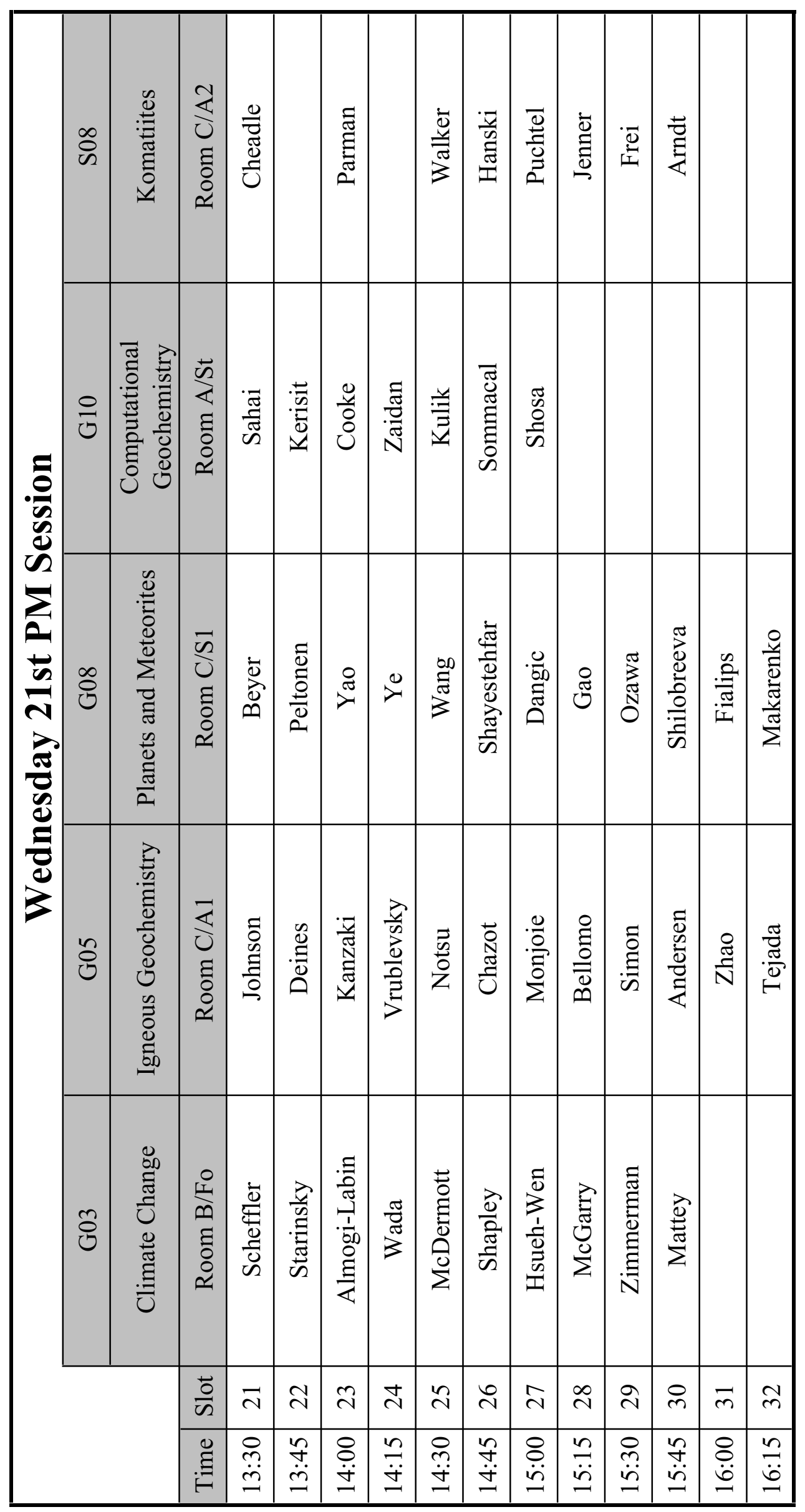




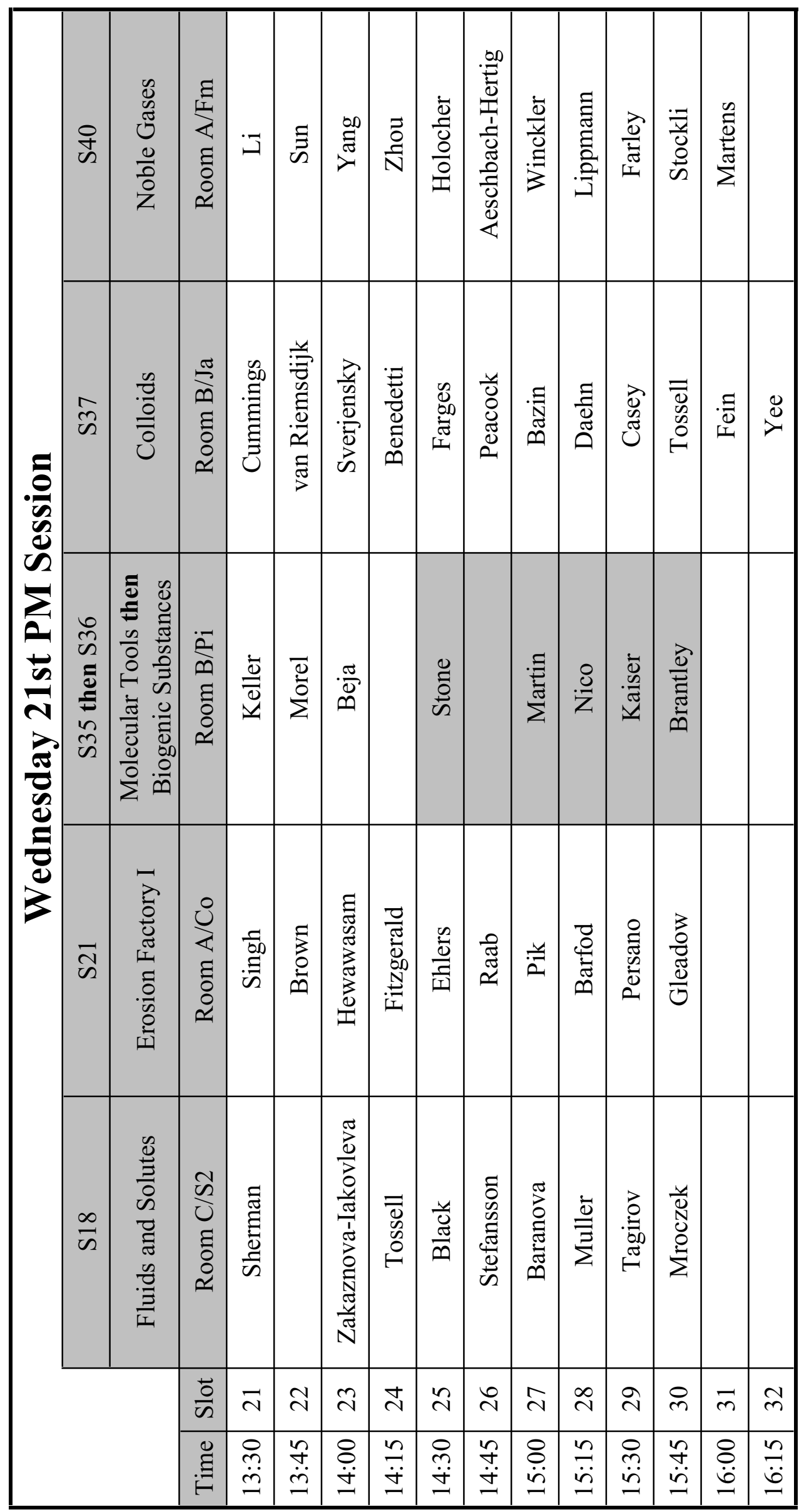




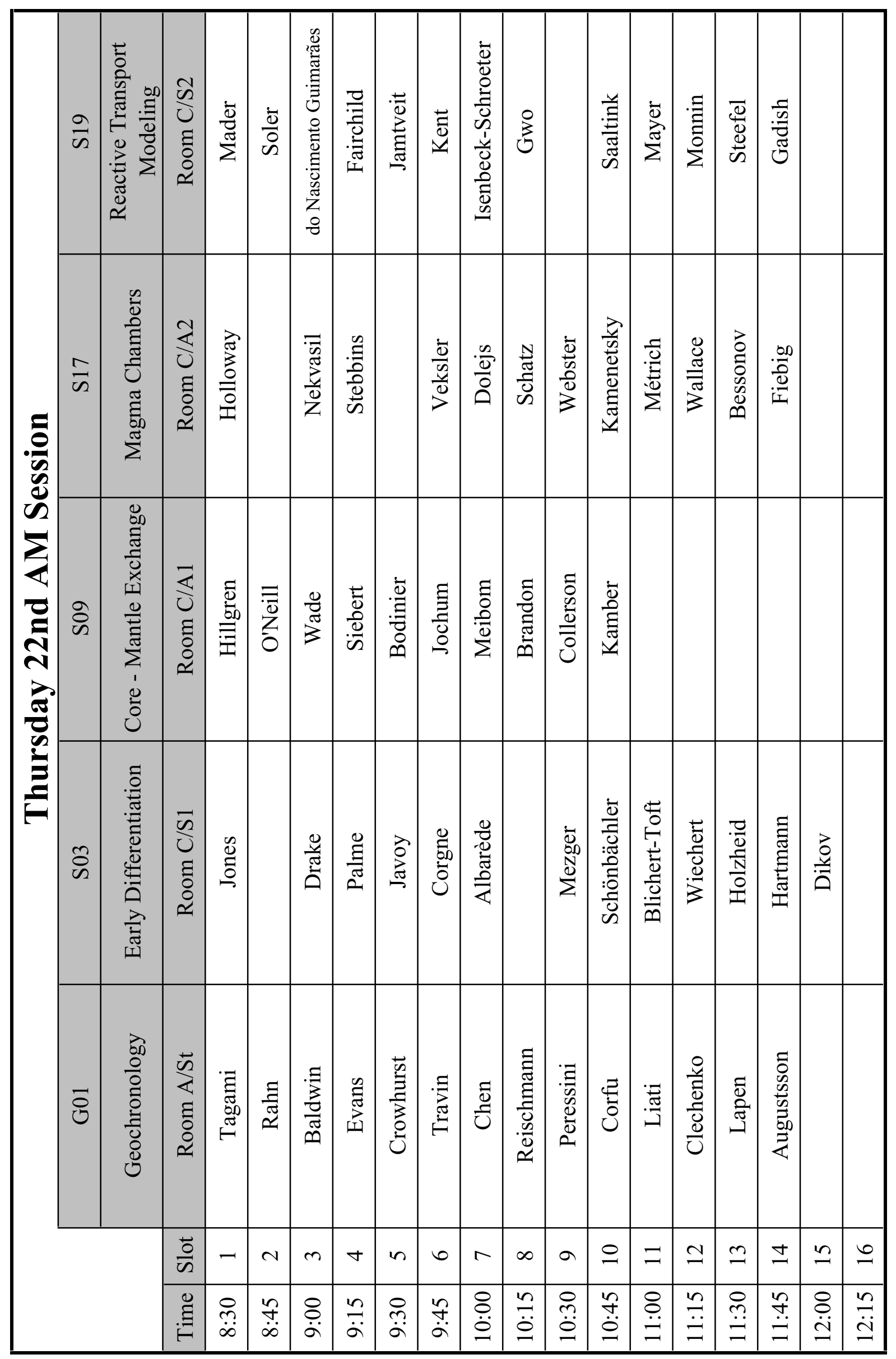




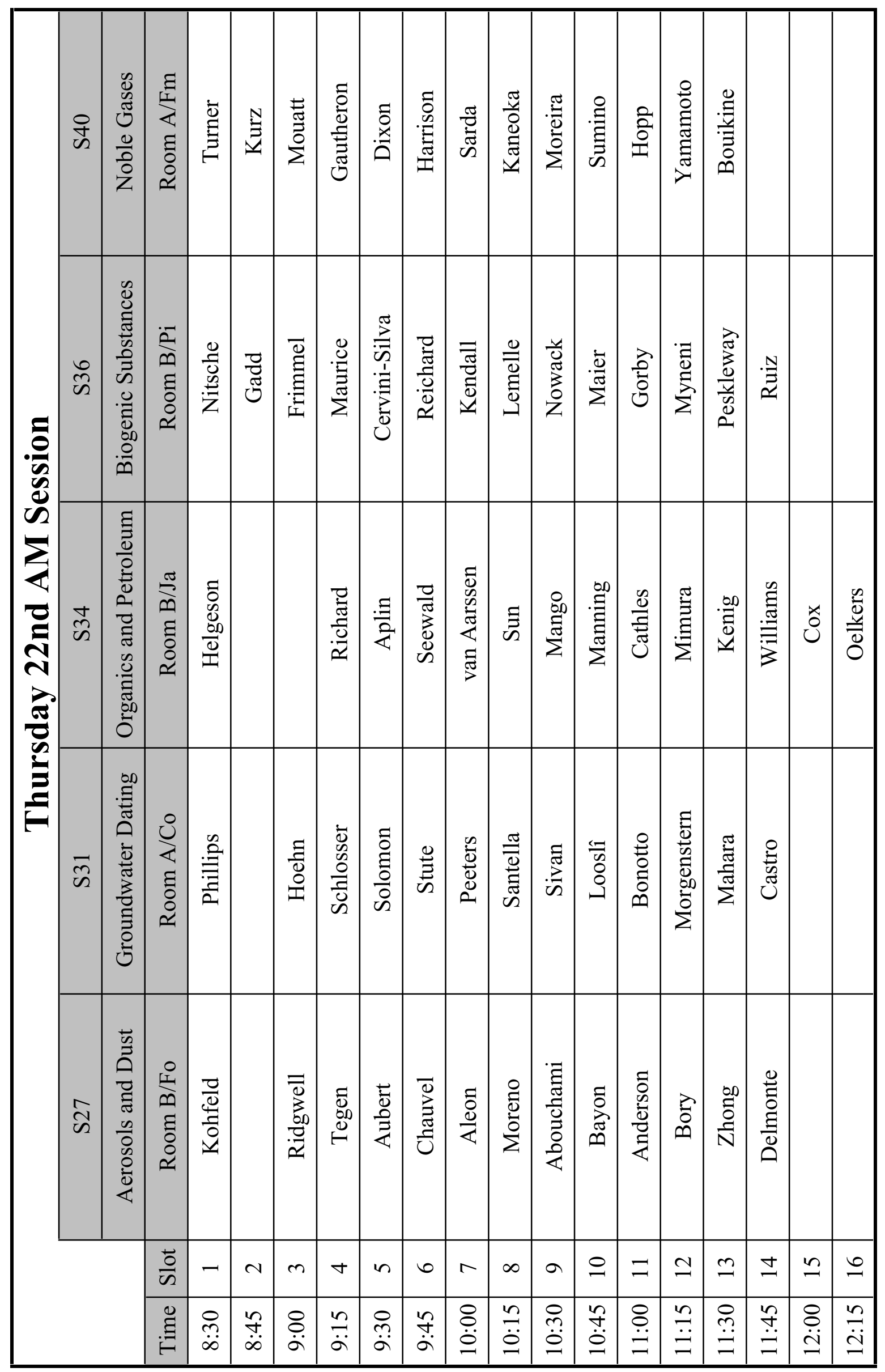




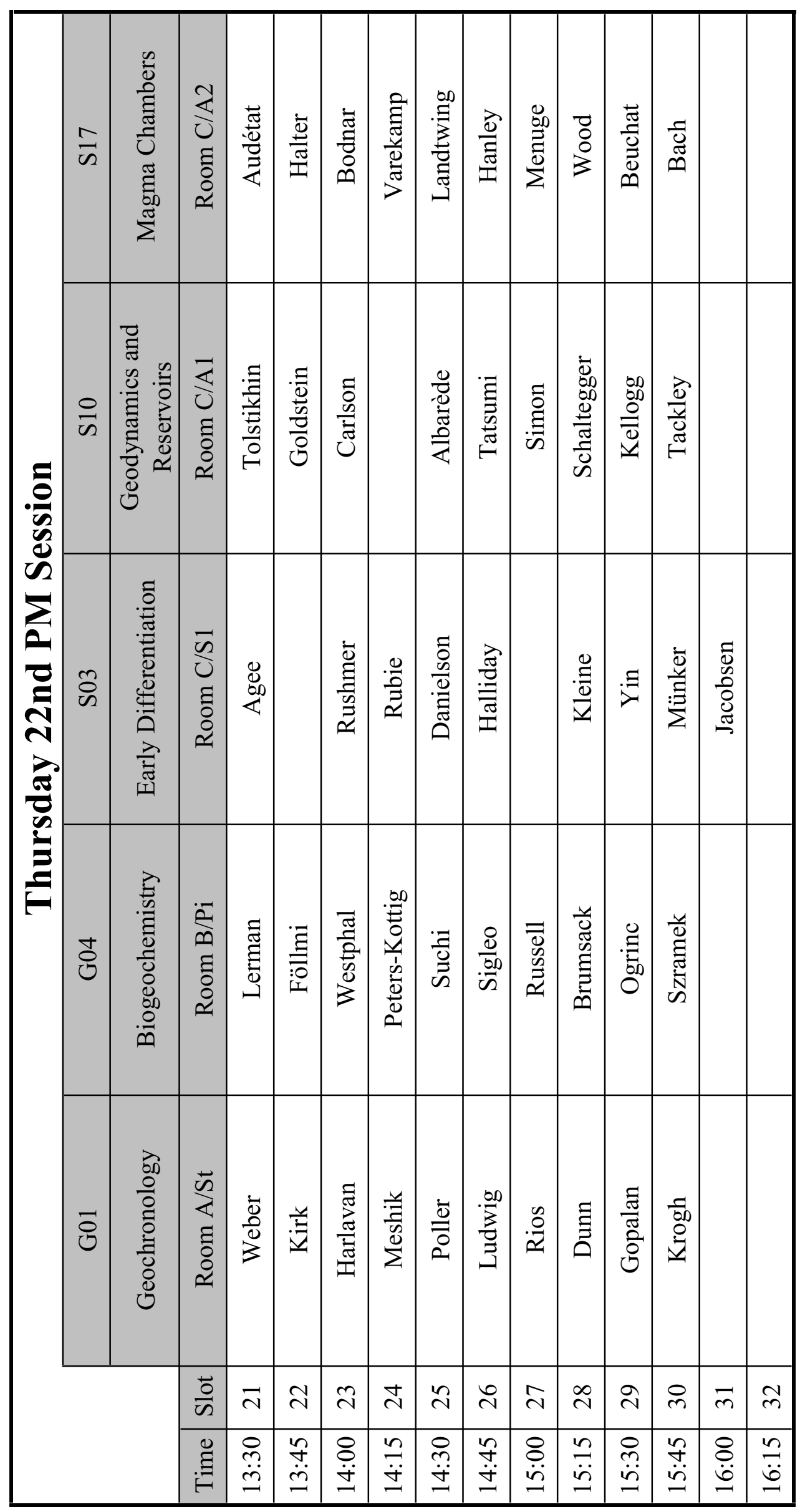




\section{Goldschmidt 2002}

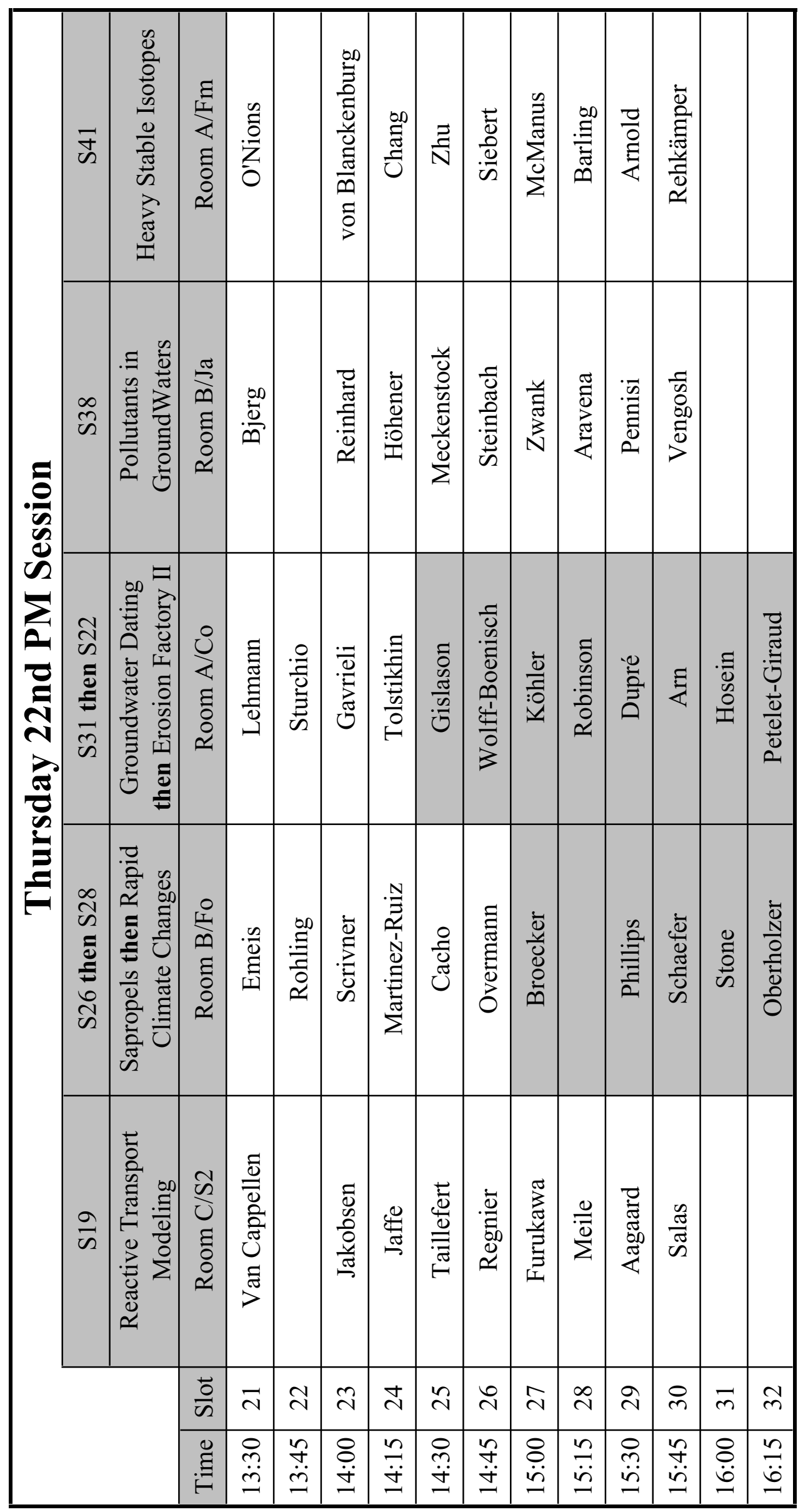




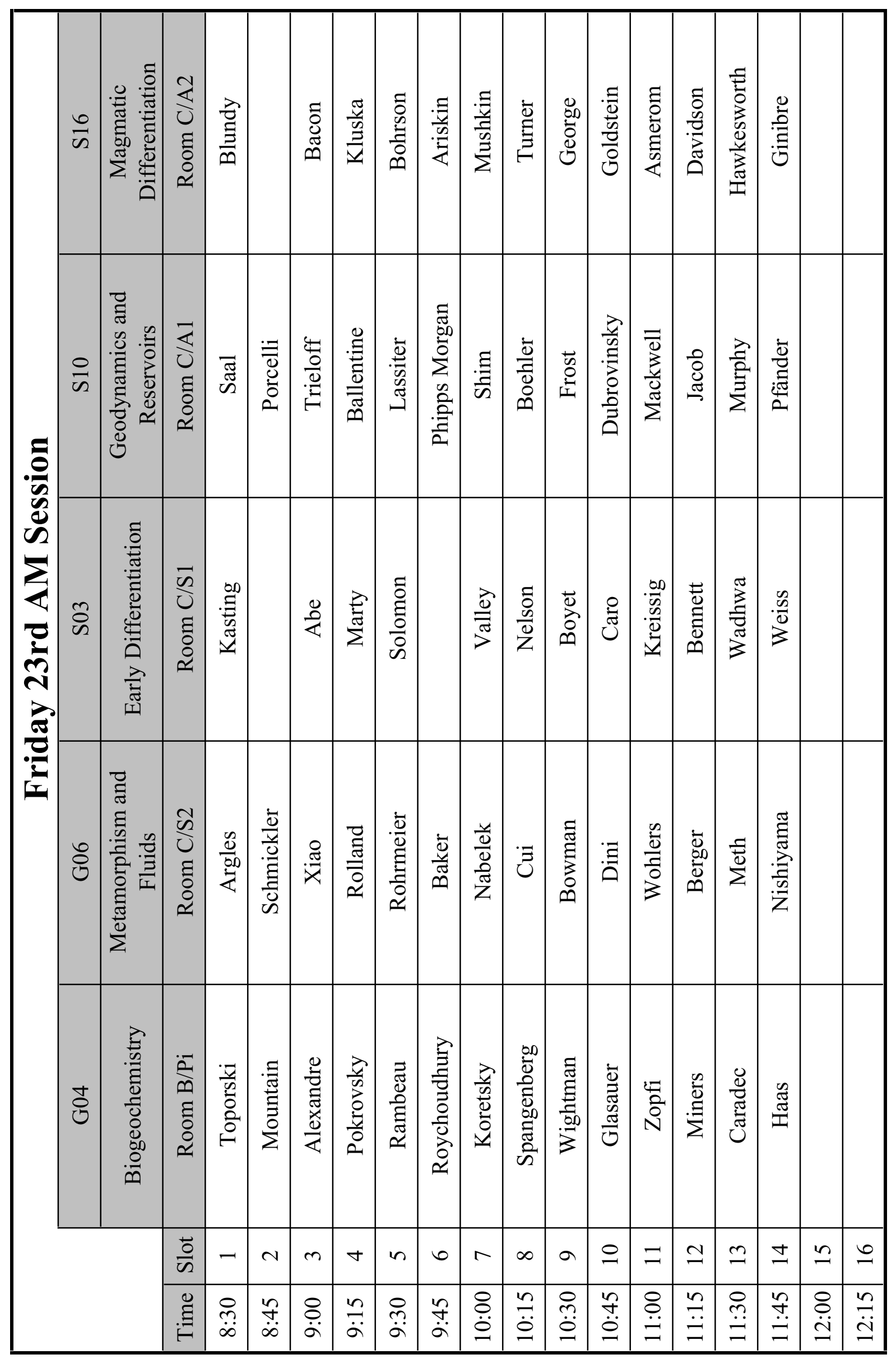




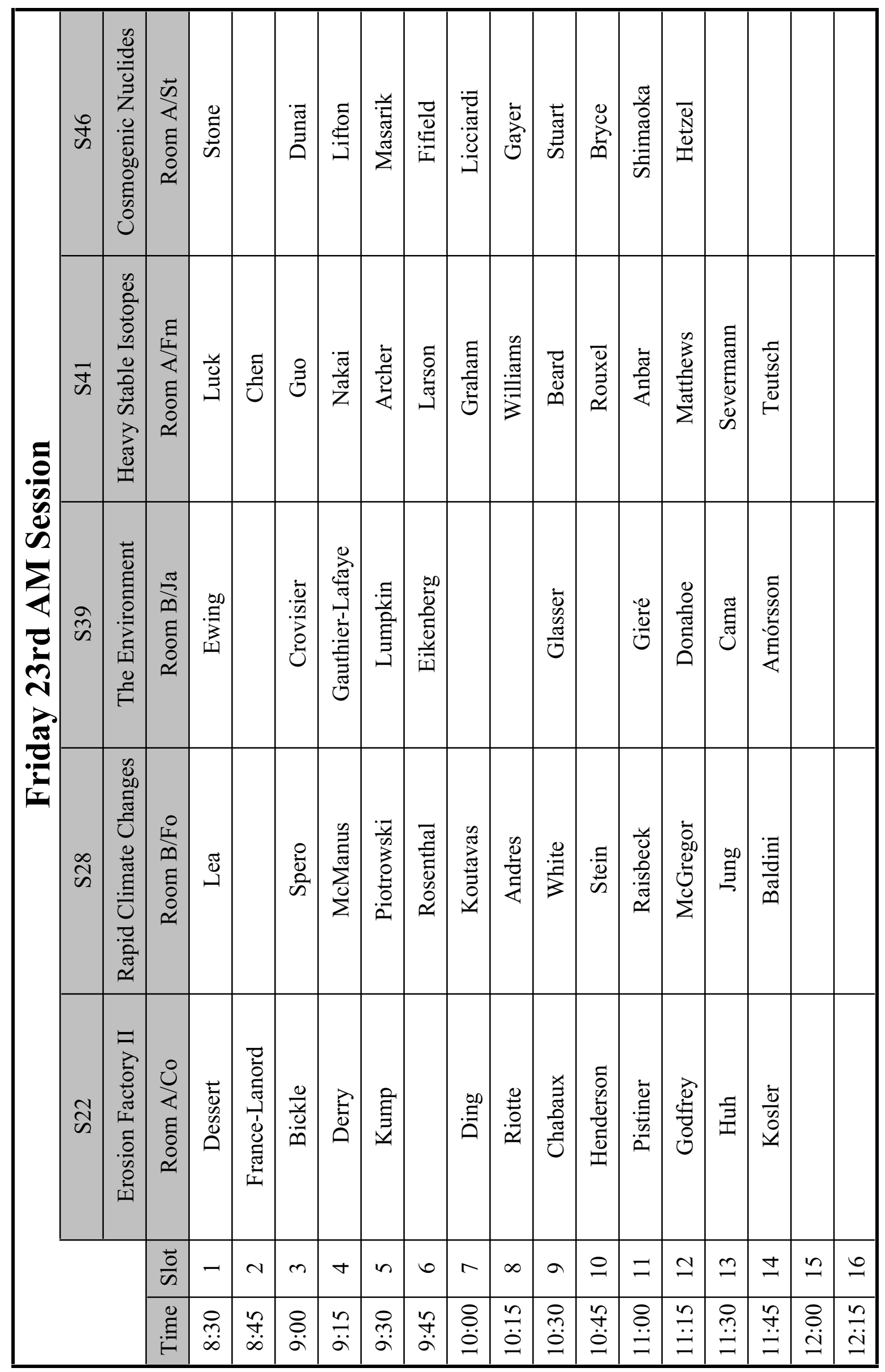




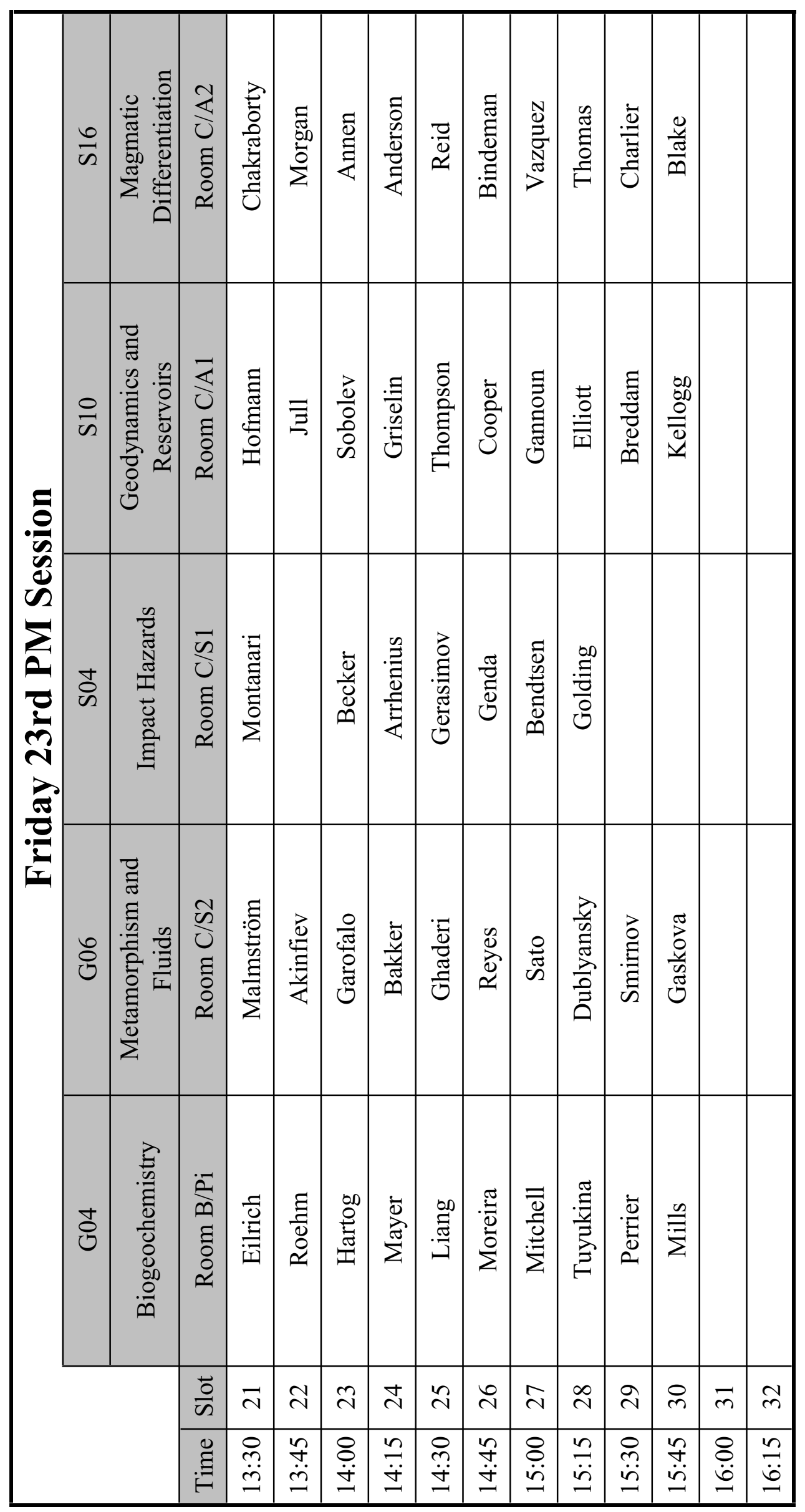




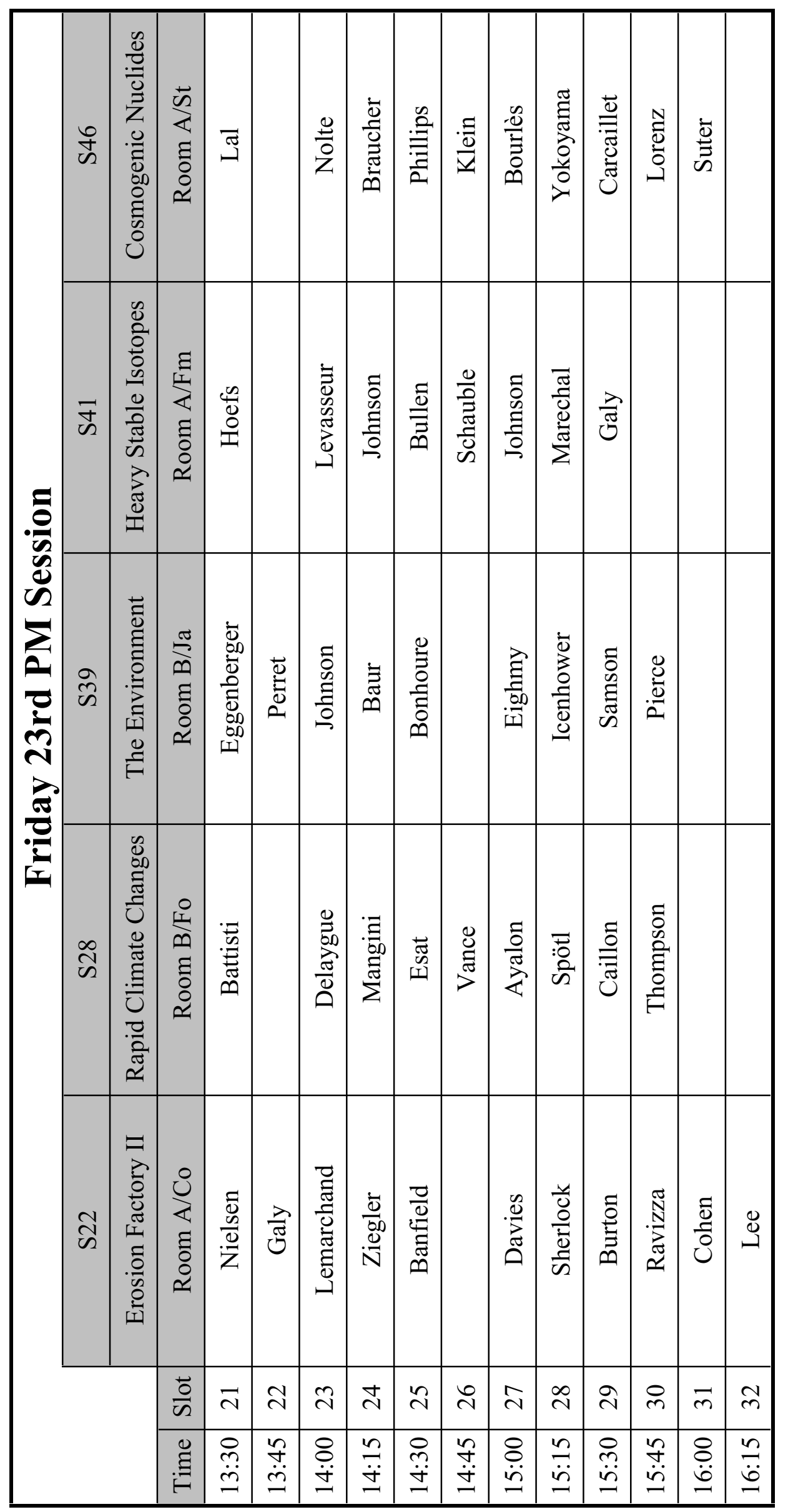


Intentionally left blank for your notes 
Intentionally left blank for your notes 
Intentionally left blank for your notes 
Intentionally left blank for your notes 


\section{nu instruments}

\section{Multi Collector - ICPMS}

\section{Nu Plasma isotope ratio}

mass spectrometers -

Designed and built for

performance and reliability
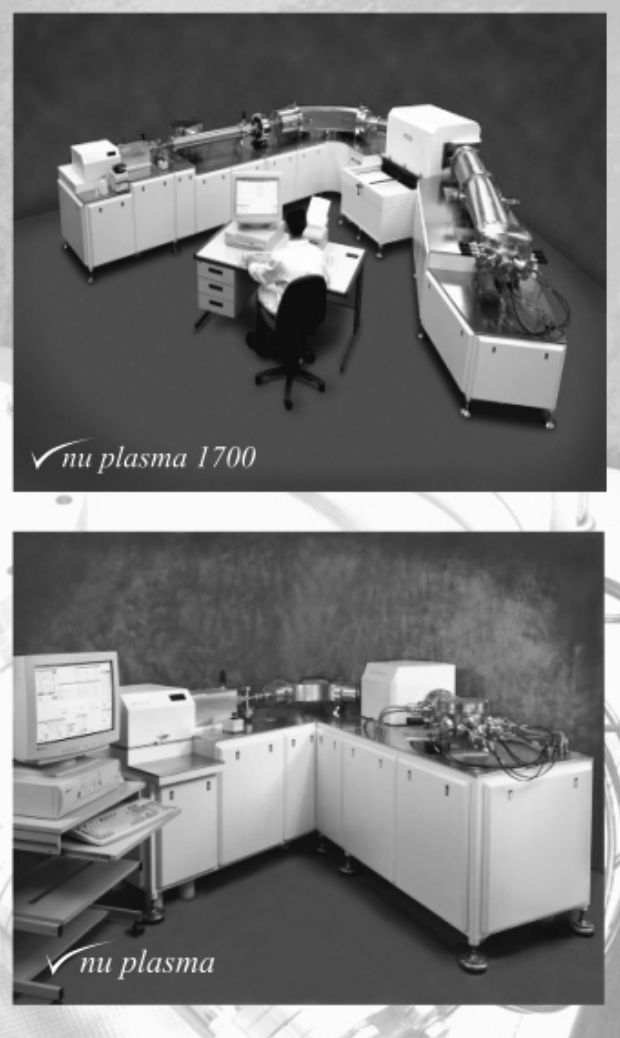

Nu Instruments Ltd

Unit 74, Clywedog Rd South, Wrexham Industrial Estate, Wrexham, LL13 9XS, UK

\section{Cambridge University Press}

Cambridge University Press publishes across the full range of the earth and environmental sciences and at all levels, from popular science and undergraduate textbooks through geochemistry includes a number of important textbooks and research volumes including:

Environmental Applications of Geochemical Modeling Chen Zhu, Greg Anderson

Introduction to Geochemical Modeling

Francis Albaréde

\section{Noble Gas Geochemistry}

2nd Edition

Minoru Ozima, Frank A. Podosek

\section{Radiogenic Isotope Geology}

Alan P. Dickin

An Introduction to Geochemistry

Francis Albaréde to graduate texts and monographs. Our publishing in

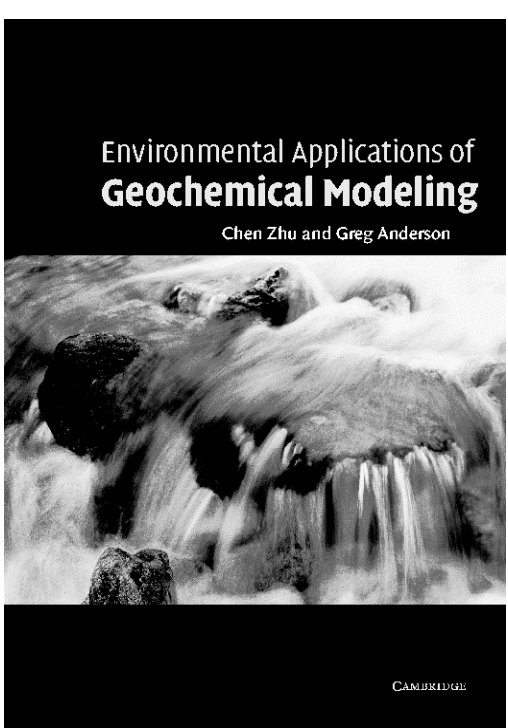

To view our complete list of earth science titles or order online, please visit www.cambridge.org/earthsciences We are actively seeking new publications in geochemistry: if you would like to discuss book publishing, please contact Dr Matt Lloyd at mlloyd@cambridge.org. 